\title{
Novel insights in the pathophysiology of colorectal anastomotic leakage
}

Citation for published version (APA):

Jongen, A. C. H. M. (2019). Novel insights in the pathophysiology of colorectal anastomotic leakage. [Doctoral Thesis, Maastricht University]. Maastricht University. https://doi.org/10.26481/dis.20190926aj

Document status and date:

Published: 01/01/2019

DOI:

10.26481/dis.20190926aj

Document Version:

Publisher's PDF, also known as Version of record

\section{Please check the document version of this publication:}

- A submitted manuscript is the version of the article upon submission and before peer-review. There can be important differences between the submitted version and the official published version of record.

People interested in the research are advised to contact the author for the final version of the publication, or visit the DOI to the publisher's website.

- The final author version and the galley proof are versions of the publication after peer review.

- The final published version features the final layout of the paper including the volume, issue and page numbers.

Link to publication

\footnotetext{
General rights rights.

- You may freely distribute the URL identifying the publication in the public portal. please follow below link for the End User Agreement:

www.umlib.nl/taverne-license

Take down policy

If you believe that this document breaches copyright please contact us at:

repository@maastrichtuniversity.nl

providing details and we will investigate your claim.
}

Copyright and moral rights for the publications made accessible in the public portal are retained by the authors and/or other copyright owners and it is a condition of accessing publications that users recognise and abide by the legal requirements associated with these

- Users may download and print one copy of any publication from the public portal for the purpose of private study or research.

- You may not further distribute the material or use it for any profit-making activity or commercial gain

If the publication is distributed under the terms of Article $25 \mathrm{fa}$ of the Dutch Copyright Act, indicated by the "Taverne" license above, 
Novel insights in the pathophysiology of colorectal anastomotic leakage 
Copyright 2019 Audrey Jongen

All rights reserved. No part of this thesis may be reproduced or distributed in any form or by any means, without the prior written permission of the author or publisher.

Layout: Tiny Wouters

Cover: IPSKAMP printing

Printed by: Printsupport4u

Publication of this thesis was financially supported by Maastricht University, Department of Surgery of the Maastricht University Medical Centre, the Nederlandse Vereniging voor Gastroenterologie (NVGE).

The work presented in this thesis was performed within NUTRIM School of Nutrition and Translational Research in Metabolism. 


\title{
Novel insights in the pathophysiology of colorectal anastomotic leakage
}

\author{
PROEFSCHRIFT
}

Ter verkrijging van de graad van doctor aan de Universiteit Maastricht, op gezag van Rector Magnificus prof. dr. Rianne M. Letschert volgens het besluit van het College van Decanen, in het openbaar te verdedigen

op

donderdag 26 september 2019 om 14:00 uur

door

Audrey Catharina Hubertina Maria Jongen

geboren op 20 juli 1989

te Sittard 


\section{Promotor}

Prof. Dr. N.D. Bouvy

\section{Copromotores}

Dr. J.P.M. Derikx

Dr. K. Lenaerts

\section{Beoordelingscommissie}

Prof. Dr. S.W.M. Olde Damink (voorzitter)

Prof. Dr. C.H.C. Dejong

Dr. M.F. Gerhards

Prof. Dr. A.A.M. Masclee

Dr. E.J.M. Nieveen van Dijkum 


\section{Table of contents}

Chapter 1 General introduction and outline of the thesis 7

$\begin{array}{lll}\text { PART I Increasing international consensus on the } & 19\end{array}$ definition of colorectal anastomotic leakage

Chapter 2 Definition of colorectal anastomotic leakage:

A consensus survey among Dutch and Chinese colorectal surgeons

Chapter 3 Use of colorectal anastomotic leakage definitions in literature: results of a systematic review and recommendations for future reporting

PART II Developing a predictive algorithm for anastomotic leakage

Chapter 4 Predictive factors for anastomotic leakage after 77 colorectal surgery: the REVEAL study: study protocol for a prospective observational study (REVEAL Study)

Chapter 5 Near-Infrared Fluorescence Image-Guidance in 89 Anastomotic Colorectal Cancer Surgery and its relation to serum markers of anastomotic leakage: a clinical pilot study

PART III Considerations regarding perioperative care of the colorectal surgery patient

Chapter 6 Contrast enema vs. colonoscopy prior to temporary stoma reversal in rectal surgery; results of 109 a national snapshot study

PART IV Novel insights in the physiology of anastomotic healing and leakage

Chapter 7 Comparison of three different application routes of butyrate to improve colonic anastomotic strength in rats 
Chapter 8 A functional mucus layer and the healing of

proximal colonic anastomoses in an

experimental model

Chapter 9 The shift in microbial composition and diversity in a rat model of NSAID induced anastomotic leak can be attributed to surgical stress

Chapter 10 General discussion

Part V Addendum

199

Summary

201

Nederlandse samenvatting

209

Valorisation

217

Dankwoord

List of publications 231

Curriculum vitae 


\section{Chapter 1}

General introduction

Partially adapted from:

Joanna WAM Bosmans, Audrey CHM Jongen, Nicole D Bouvy, Joep PM Derikx

Colorectal anastomotic healing: why the the biological processes that lead to anastomotic leakage should be revealed prior to conducting intervention studies

BMC Gastroenterol. 2015;15;180

and

Audrey CHM Jongen, Victor van Woerden, Jeroen L van Vugt, Patrick A de Hoogt, Elisabeth M de Wijkerslooth de Weerdesteijn, Juul J Tegels, Jan H Stoot

Improving outcome in gastrointestinal and hepatopancreaticobiliary surgical oncology by preoperative risk assessment and optimization of perioperative care

Book chapter - Oncology Critical Care 



\section{General introduction}

Colorectal anastomotic leakage (CAL) is the most feared complication following colorectal surgery, with incidence rates between $7-10 \%$. It is associated with high rates of morbidity and mortality ${ }^{1,2}$, poor health-related quality of life (HRQoL) $)^{3,4}$ and an increase of healthcare costs ${ }^{5}$. Recent reports have even found an association between CAL and a poor oncological outcome, which reflects in increased local recurrence rates and decreased disease-specific survival ${ }^{6-8}$. Studies that have been conducted on this topic have revealed several risk factors for the occurrence of CAL such as: male gender, old age, smoking, corticosteroid and NSAID use, diabetes mellitus, pre-operative radiotherapy and low level of the anastomosis ${ }^{9,10}$. Several others have examined options to decrease the incidence rates of CAL after surgery, however only a few of the developed preventive methods indeed made it into the clinical setting, including luminal devices such as the $\mathrm{C}$-seal ${ }^{11}$, alternative closure devices such as the (magnetic) compression ring ${ }^{12,13}$ and patches (e.g. TachoSil $\left.{ }^{\circledR}\right)^{14}$. In the experimental setting, several tissue glues have been investigated for their ability to strengthen the anastomosis. The most often tested glues include fibrin or cyanoacrylate glues ${ }^{15}$, of which the fibrin glues yield the most promising results ${ }^{16}$. However, none of the investigated preventive techniques are currently being used in routine clinical practice, and have failed to decrease the incidence rates of $\mathrm{CAL}^{9}$. An explanation for the failure of implementation of these innovative techniques could be that they are not specifically aimed at the healing process of the gut, as the mechanisms behind this are largely unknown. We believe that the pathophysiological processes involved in the occurrence of CAL need to be elucidated first and foremost in order to find specific targets for new preventive techniques.

An important aspect of the pathogenesis is the composition of the luminal content near the site of the anastomosis, of which the microbiome comprises a substantial part. Several studies have shown that different microbes can change into a more virulent phenotype when exposed to factors such as (surgical) stress and systemic opioids ${ }^{17,18}$. These more virulent bacteria have been shown to increase their production of collagenases, which weakens the anastomotic strength and consequently increases the CAL risk ${ }^{19}$. Other studies have found a relationship between composition of the microbiome and leakage, such as diversity and the balance between bacteroides and firmicutes ${ }^{20}$. More insight in the exact role and composition of the microbiota on the processes of intestinal healing would also aid in the choice of antimicrobial prophylaxis or bowel preparation, something that varies substantially between hospitals. 
During the past decade, more attention has been paid to assessing and optimizing the preoperative condition of our patients. Especially in the light of the increasing age of our general population, it is important to consider the impact of surgery on the functional reserve of our patients. Even though improvements in the perioperative care over the past decades reflect positively on the outcome of the overall patient population, the older patient (octo- and nonagenerians) has benefited much less from these improvements ${ }^{21}$. Identifying the patient at risk for an adverse outcome is therefore of great importance, and several tools can be used to do this. Sarcopenia for example is considered a hallmark sign of frailty, and is characterized by a loss of skeletal muscle mass and strength ${ }^{22}$. Multiple studies have shown an association between the presence of sarcopenia and adverse outcome after surgery, for example for patients undergoing surgery for colorectal liver metastases ${ }^{23}$. Optimizing the patient's condition before surgery has been proven to be beneficial for short and long-term morbidity and mortality rates in other surgical fields, and is currently being investigated in colorectal patients $^{24}$.

Another preoperative issue that is still under debate is whether patients should be subjected to bowel preparation. Although the evidence for mechanical bowel preparation is still inconclusive, the use of (oral) antibiotics can be supported by several studies and meta-analyses ${ }^{25,26}$. A meta-analysis published in 2016 concludes that bowel preparation alone does not decrease the risk for $C A L$, but should be used in combination with oral (and not only systemic) antibiotics in order to decrease the bacterial load in the gut $^{25}$.

The surgical procedure itself has proven to be important as well, and parameters such as mean arterial pressure (MAP), body temperature, duration of surgery and the amount of blood loss have been identified as risk factors for $\mathrm{CAL}^{27-30}$. It has been suggested that the perfusion of the intestinal tissue is one of the most important aspects of successfully constructing an anastomosis. Near infrared fluorescence imaging is therefore being used in operation theatres more often, as it allows surgeons to visualize the microperfusion of the intestine in real-time. It has been shown to significantly improve safety of colorectal surgery $^{31,32}$.

The question whether or not to construct a (temporary) colostomy or ileostomy remains debatable. For example, it seems advisable to construct a temporary ileostomy when a low anterior resection (LAR) is indicated, but some surgeons opt for a colostomy instead. It is debatable however to routinely construct a deviation in all patients undergoing a $L A R$, as it is unclear when the risks outweigh the benefits of such a deviation. It has been shown that although the presence of a deviating ostomy mitigates the clinical consequences of a leak, the risk of developing a leak does not decrease $e^{33-35}$. 
Furthermore, stoma complications have a reported incidence of up to $30 \%$, ranging from skin complications and high output to herniation and stoma prolapse, which often requires reoperation ${ }^{33,36}$. Temporary stoma reversal exposes the patient to the risks of another operation, including anastomotic leakage. Finally, a large proportion of all ostomies that were initially planned to be only temporary will never be reversed, which severely affects $\mathrm{QoL}^{36,37}$. For the more proximal resections, evidence and guidelines are even less unambiguous.

\section{Aim and outline of this thesis}

\section{PART I: increasing international consensus on the definition of colorectal anastomotic leakage}

Several definitions have been proposed for CAL during the past decades, but none of these have been implemented in clinical practice yet. The fact that authors use different definitions that include a smaller or larger variety of clinical presentations of the complication makes comparison of study results between studies rather difficult, and meta-analyses nearly impossible. The use of different definitions could also explain for the variance in reported incidence rates between studies and even between continents.

\section{Aims}

- Increasing insight of what is considered colorectal anastomotic leakage by surgeons in different continents

- Increasing insight in what types of definitions of CAL are being used in literature and how these definitions influence reported incidence rates

The first part of this thesis describes the first steps of a process to develop a generally accepted definition for CAL. In Chapter 2, a survey among Chinese and Dutch colorectal surgeons is described that investigated the different views regarding what should be considered colorectal anastomotic leakage. The results of this chapter partly explain the difference in reported incidence between Western and Eastern countries and give more insight in the views of colorectal surgeons as to what should be included in a general definition for CAL. Chapter 3 is a systematic review that focuses on the use of different CAL definitions in literature. In this chapter, we also give recommendations regarding the reporting of data for studies with colorectal anastomotic leakage as one of their main outcomes. 


\section{PART II: Developing a predictive algorithm for anastomotic leakage}

Despite the numerous studies that have been conducted in the past focusing on risk factors for colorectal anastomotic leakage, accurate prediction of the occurrence of such a leak in the individual patient remains impossible. In fact, a study conducted by Karliczek et al. has shown that the assessment of the risk of a complicated postoperative course by the colorectal surgeon during surgery and immediately after the construction of an anastomosis is highly inaccurate ${ }^{38}$. Several other studies have focused on finding biomarkers for colorectal anastomotic leakage, in order to be able to set the diagnosis at an earlier stage. Indeed, mean time of diagnosis AL varies greatly, from postoperative day 3 to beyond 30 days, with a mean of 12.7 days postoperatively ${ }^{39}$. It has been shown that early recognition of CAL substantially reduces the morbidity and mortality associated with the complication ${ }^{40}$.

\section{Aims}

- $\quad$ formulating a predictive algorithm that can be used to assess the risk of CAL in every individual patient

- diagnosing the development of a leakage in earlier stages

- $\quad$ quantification of the microperfusion of the intestine during surgery

Part II of this thesis focuses on the development of adequate prediction of the risk of CAL and diagnosis of the complication in early stages. Chapter 4 is a study protocol for a large observational study that is currently being conducted in three hospitals in the Netherlands: Zuyderland Medical Centre in Sittard-Geleen, VieCuri Medical Centre in Venlo, and the Maastricht University Medical Centre. In Chapter 5, we have investigated the use of near infrared fluorescence (NIRF) imaging after intravenous indocyanine green (ICG) administration during colorectal surgery, and the correlation between fluorescence intensity and postoperative inflammatory markers.

\section{PART III: Considerations regarding perioperative care of the colorectal surgical patient}

The perioperative care has undergone substantial changes over the past decade. Some of these involve the preoperative phase. For example, physicians have aimed to improve the condition of the patient prior to undergoing surgery by means of so called prehabilitation programmes. In these programmes, a multidisciplinary team works together to focus on fitness, nutritional status and body composition. During this perioperative period, several decisions have to be taken by the surgical team for every individual 
patient on a daily basis. These include for example whether or not to prepare the bowel by decontamination by means of enemas and antibiotics, and whether or not to construct a deviating ostomy. For most of these dilemmas, the surgical community has failed to reach consensus. The need to assess the integrity of the anastomosis prior to temporary stoma reversal, and which method is most accurate to do so, is a good example of such a dilemma. In part III of this thesis, we will focus on this question in more detail.

As mentioned in the general introduction, CAL is associated with high rates of comorbidity and mortality, and has been identified as a risk factor for cancer recurrence and reduced disease-specific survival ${ }^{41}$. The reason for this correlation remains largely unknown, but several mechanisms have been proposed to explain these findings. One theory states that anastomotic leakage could lead to the mechanical spreading of viable cancer cells into the peritoneal cavity, others believe that the increased postoperative inflammatory response stimulates growth and proliferation of tumour cells. Because of the impact that colorectal anastomotic leakage has on the oncological outcome in the long-term, we have also focused on this question in part III of this thesis. Indeed, better understanding of the prognostic relevance of the inflammatory parameters might assist in patient selection for adjuvant therapy in the future.

\section{Aims}

- Comparing the accuracy of contrast enema and coloscopy for the assessment of the integrity of the anastomosis prior to temporary stoma reversal

- Investigating the relationship between the inflammatory response and the oncological prognosis after colorectal cancer surgery

In Chapter 6, we investigated which type of diagnostic method is most suitable for the assessment of integrity of the anastomosis before temporary stoma reversal. We have investigated this in a large cohort of patients that underwent rectal surgery in 2011. Chapter 7 focuses on the association between an increased perioperative inflammatory status and the risk of recurrence and disease-specific mortality after colorectal cancer surgery.

\section{PART IV: Novel insights in the (patho)physiology of anastomotic healing and leakage}

As our research group has discussed in our debate paper, very little is known about the exact mechanism underlying the pathophysiology of CAL. Moreover, little research has been done on normal intestinal healing. We know that the general phases of healing also 
occur in the intestine (inflammation, proliferation, remodelling), and that an important interaction exists with the mucosal and luminal microbiome and the intestinal wall and mucosa. Several other studies have focused on the role of possible beneficial compounds such as the short-chain fatty acid butyrate, which is the most important source of energy for the colonocyte, and has been shown to increase proliferation rates both in vitro and in vivo. However, many questions regarding the exact mechanistic pathways remain unanswered. We have stressed the need for studies investigating these processes before more intervention studies are to be conducted.

Aims:

- Investigating the optimal application method for butyrate in a rat model

- Investigating the role of the mucus layer in the intestinal healing process in a murine model

- Investigating the influence of diclofenac and surgery on the composition of the microbiome in a rat model

In Chapter 8, we have investigated different application routes (patch, injection, enema) for butyrate to improve intestinal healing in a rat model. Previous animal studies showed that butyrate enemas had a beneficial effect on the strength of (distal) colonic anastomoses $^{42}$. In our experiments, the glycosaminoglycan hyaluronan was added to the mixture, which is known to promote neovascularization, has beneficial effects on cell proliferation, and diminishes the inflammatory response ${ }^{43}$. In Chapter 9, we have focused on the role of the mucus layer, the primary line of defence in the gastrointestinal tract and the home of a large variety of microbial species. The amount of mucin secreted by the goblet cells influences the ability of the mucus layer to protect the colon wall, and several conditions have been shown to alter the mucin secretion such as the presence of SCFA's and certain types of bacteria ${ }^{44}$. Prostaglandin E2 (PGE2), which is an enzymatic product of cyclo-oxygenase (COX) 1 and 2 has also been shown to positively influence the mucus secretion ${ }^{45}$. Non-steroidal anti-inflammatory drugs (NSAIDS) inhibit COX, and therefore cause a decrease in PG synthesis ${ }^{46}$. We constructed an anastomosis in the distal colon of muc2 knockout mice and wild-type controls, and investigated whether the administration of prostaglandin E2, an important inflammatory mediator, exerted an effect on the thickness of the mucus layer and/or on the leakage rates in this model. Chapter 10 describes another animal study in which the effect of surgery and a non-steroidal anti-inflammatory drug (NSAID) - in this case diclofenac was studied on the composition of the microbiome in the rat before and after the construction of an anastomosis in different sites of the intestinal tract. 


\section{References}

1. Kirchhoff P, Clavien PA, Hahnloser D. Complications in colorectal surgery: risk factors and preventive strategies. Patient Saf Surg 2010;4(1):5.

2. Bertelsen $\mathrm{CA}$, Andreasen $\mathrm{AH}$, Jorgensen $\mathrm{T}$, et al. Anastomotic leakage after curative anterior resection for rectal cancer: short and long-term outcome. Colorectal Dis 2010;12(7 Online):e76-81.

3. McArdle CS, McMillan DC, Hole DJ. Impact of anastomotic leakage on long-term survival of patients undergoing curative resection for colorectal cancer. Br J Surg 2005;92(9):1150-4.

4. Ashburn JH, Stocchi L, Kiran RP, et al. Consequences of anastomotic leak after restorative proctectomy for cancer: effect on long-term function and quality of life. Dis Colon Rectum 2013;56(3):275-80.

5. Hammond J, Lim S, Wan Y, et al. The burden of gastrointestinal anastomotic leaks: an evaluation of clinical and economic outcomes. J Gastrointest Surg 2014;18(6):1176-85.

6. Mirnezami A, Mirnezami R, Chandrakumaran K, et al. Increased local recurrence and reduced survival from colorectal cancer following anastomotic leak: systematic review and meta-analysis. Ann Surg 2011;253(5):890-9.

7. Kulu Y, Tarantio I, Warschkow R, et al. Anastomotic leakage is associated with impaired overall and disease-free survival after curative rectal cancer resection: a propensity score analysis. Ann Surg Oncol 2015;22(6):2059-67.

8. Law WL, Choi HK, Lee YM, et al. Anastomotic leakage is associated with poor long-term outcome in patients after curative colorectal resection for malignancy. J Gastrointest Surg 2007;11(1):8-15.

9. McDermott FD, Heeney A, Kelly ME, et al. Systematic review of preoperative, intraoperative and postoperative risk factors for colorectal anastomotic leaks. Br J Surg 2015;102(5):462-79.

10. Hakkarainen TW, Steele SR, Bastaworous A, et al. Nonsteroidal anti-inflammatory drugs and the risk for anastomotic failure: a report from Washington State's Surgical Care and Outcomes Assessment Program (SCOAP). JAMA Surg 2015;150(3):223-8.

11. Bakker IS, Morks AN, Ten Cate Hoedemaker HO, et al. Randomized clinical trial of biodegradeable intraluminal sheath to prevent anastomotic leak after stapled colorectal anastomosis. Br J Surg 2017;104(8):1010-9.

12. Graves CE, Co C, Hsi RS, et al. Magnetic Compression Anastomosis (Magnamosis): First-In-Human Trial. J Am Coll Surg 2017;225(5):676-81 e1.

13. Masoomi H, Luo R, Mills $\mathrm{S}$, et al. Compression anastomosis ring device in colorectal anastomosis: a review of 1,180 patients. Am J Surg 2013;205(4):447-51.

14. Parker MC, Pohlen U, Borel Rinkes $\mathrm{IH}$, et al. The application of TachoSil(R) for sealing colorectal anastomosis: a feasibility study. Colorectal Dis 2013;15(2):252-7.

15. Wu Z, Boersema GS, Vakalopoulos KA, et al. Critical analysis of cyanoacrylate in intestinal and colorectal anastomosis. J Biomed Mater Res B Appl Biomaters 2014;102(3):635-42.

16. Vakalopoulos KA, Daams F, Wu Z, et al. Tissue adhesives in gastrointestinal anastomosis: a systematic review. J Surg Res 2013;180(2):290-300.

17. Defazio J, Fleming ID, Shakhsheer B, et al. The opposing forces of the intestinal microbiome and the emerging pathobiome. The Surgical clinics of North America 2014;94(6):1151-61.

18. Hayakawa $\mathrm{M}$, Asahara $\mathrm{T}$, Henzan $\mathrm{N}$ et al. Dramatic changes of the gut flora immediately after severe and sudden insults. Dig Dis Sci 2011;56(8):2361-5.

19. Shogan BD, Belogortseva N, Luong PM, et al. Collagen degradation and MMP9 activation by Enterococcus faecalis contribute to intestinal anastomotic leak. Sci Transl Med 2015;7(286):286ra68.

20. van Praagh JB, de Goffau MC, Bakker IS, et al. Mucus microbiome of anastomotic tissue during surgery has predictive value for colorectal anastomotic leakage. Ann Surg 2019;269(5):911-6.

21. van Vugt JL, Reisinger KW, Derikx J,P et al. Improving the outcomes in oncological colorectal surgery. World J Gastroenterol 2014;20(35):12445-57.

22. Cruz-Jentoft AJ, Baeyens JP, Bauer JM, et al. Sarcopenia: European consensus on definition and diagnosis: Report of the European Working Group on Sarcopenia in Older People. Age Ageing 2010;39(4):412-23. 
23. van Vledder MG, Levolger $\mathrm{S}$, Ayez $\mathrm{N}$, et al. Body composition and outcome in patients undergoing resection of colorectal liver metastases. Br J Surg 2012;99(4):550-7.

24. Mayo NE, Feldman L, Scott S, et al. Impact of preoperative change in physical function on postoperative recovery: argument supporting prehabilitation for colorectal surgery. Surgery 2011;150(3):505-14.

25. Chen M, Song X, Chen LZ, et al. Comparing mechanical bowel preparation with both oral and systemic antibiotics versus mechanical bowel preparation and systemic antibiotics alone for the prevention of surgical site infection after elective colorectal surgery: a meta-analysis of randomized controlled clinical trials. Dis Colon Rectum 2016;59(1):70-8.

26. Nelson RL, Gladman E, Barbateskovic M. Antimicrobial prophylaxis for colorectal surgery. The Cochrane database of systematic reviews 2014(5):CD001181.

27. Leone $\mathrm{M}$, Asfar $\mathrm{P}$, Radermacher $\mathrm{P}$, et al. Optimizing mean arterial pressure in septic shock: a critical reappraisal of the literature. Crit Care 2015;19:101.

28. Mehta OH, Barclay KL. Perioperative hypothermia in patients undergoing major colorectal surgery. ANZ J Surg 2014;84(7-8):550-5.

29. Kambakamba P, Dindo D, Nocito A, et al. Intraoperative adverse events during laparoscopic colorectal resection--better laparoscopic treatment but unchanged incidence. Lessons learnt from a Swiss multiinstitutional analysis of 3,928 patients. Langenbecks Arch Surg 2014;399(3):297-305. d

30. Midura EF, Hanseman D, Davis BR, et al. Risk factors and consequences of anastomotic leak after colectomy: a national analysis. Dis Colon Rectum 2015;58(3):333-8.

31. van den Bos J, Al-Taher M, Schols RM, et al. Near-infrared fluorescence imaging for real-time intraoperative guidance in anastomotic colorectal surgery: a systematic review of literature. J Laparoendosc Adv Surg Tech A. 2018;28(2):157-67.

32. Blanco-Colino R, Espin-Basany E. Intraoperative use of ICG fluorescence imaging to reduce the risk of anastomotic leakage in colorectal surgery: a systematic review and meta-analysis. Techn Coloproctol 2018;22(1):15-23.

33. Gessler B, Haglind E, Angenete E. Loop ileostomies in colorectal cancer patients--morbidity and risk factors for nonreversal. J Surg Res 2012;178(2):708-14.

34. Shiomi A, Ito M, Maeda K, et al. Effects of a diverting stoma on symptomatic anastomotic leakage after low anterior resection for rectal cancer: a propensity score matching analysis of 1,014 consecutive patients. J Am Coll Surg 2015;220(2):186-94.

35. Matthiessen P, Hallbook O, Rutegard J, et al. Defunctioning stoma reduces symptomatic anastomotic leakage after low anterior resection of the rectum for cancer: a randomized multicenter trial. Ann Surg 2007;246(2):207-14.

36. den Dulk M, Smit M, Peeters KC, et al. A multivariate analysis of limiting factors for stoma reversal in patients with rectal cancer entered into the total mesorectal excision (TME) trial: a retrospective study. Lancet Oncol 2007;8(4):297-303.

37. Pan HD, Peng YF, Wang L, et al. Risk Factors for Nonclosure of a Temporary Defunctioning Ileostomy Following Anterior Resection of Rectal Cancer. Dis Colon Rectum 2016;59(2):94-100.

38. Karliczek A, Harlaar NJ, Zeebregts CJ, et al. Surgeons lack predictive accuracy for anastomotic leakage in gastrointestinal surgery. Int J Colorectal Dis 2009;24(5):569-76.

39. Hyman N, Manchester TL, Osler T, et al. Anastomotic leaks after intestinal anastomosis: it's later than you think. Ann Surg 2007;245(2):254-8.

40. Alves $\mathrm{A}$, Panis $\mathrm{Y}$, Pocard $\mathrm{M}$, et al. Management of anastomotic leakage after nondiverted large bowel resection. J Am Coll Surg 1999;189(6):554-9.

41. Clinical trial of prophylaxis of wound sepsis in elective colorectal surgery comparing ticarcillin with tinidazole. University of Melbourne Colorectal Group. Aust N Z J Surg 1986;56(3):209-13.

42. Mathew AJ, Wann VC, Abraham DT, et al. The effect of butyrate on the healing of colonic anastomoses in rats. J Invest Surg 2010;23(2):101-4.

43. Price RD, Berry MG, Navsaria HA. Hyaluronic acid: the scientific and clinical evidence. J Plastic Reconstr Aesthet Surg 2007;60(10):1110-9.

44. Barcelo A, Claustre J, Moro F, et al. Mucin secretion is modulated by luminal factors in the isolated vascularly perfused rat colon. Gut 2000;46(2):218-24. 
45. Ermund A, Schutte A, Johansson ME, et al. Studies of mucus in mouse stomach, small intestine, and colon. I. Gastrointestinal mucus layers have different properties depending on location as well as over the Peyer's patches. Am J Physiol Gastrointest Liver Physiol 2013;305(5):G341-7.

46. Vane JR, Botting RM. Anti-inflammatory drugs and their mechanism of action. Inflamm Res 1998;47 Suppl 2:S78-87. 

Part

Increasing international consensus on the definition of colorectal anastomotic leakage 



\section{Chapter}

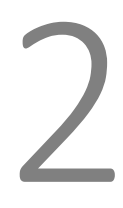

Definition of colorectal anastomotic leakage: consensus survey among Dutch and Chinese colorectal surgeons

Stefanus J van Rooijen*, Audrey CHM Jongen*, Zhouqiao Wu*, Jiafu Ji, Gerrit D Slooter, Rudy MH Roumen, Nicole D Bouvy World J Gastroenterol. 2017;23(33):6172-6180 


\section{Abstract}

Introduction

Colorectal anastomotic leakage (CAL) is the most feared complication after colorectal surgery. Despite increased awareness of the complication, no consensus exists for a general definition for CAL. The large variety in applied definitions may partly explain differences in reported CAL incidence between Asian and Western studies (1.5-23\%) and complicates the interpretation of reported outcomes.

Aim

The purpose of this study was to determine the level of consensus on the definition of CAL among Dutch and Chinese colorectal surgeons.

Methods

Dutch and Chinese colorectal surgeons were asked to partake in an online questionnaire. Consensus in the online questionnaire was defined as $>80 \%$ agreement between respondents on various statements regarding a general definition of CAL, and regarding clinical and radiological diagnosis of the complication.

Results

Fifty-nine Dutch and 202 Chinese dedicated colorectal surgeons participated in the online survey. Consensus was found on only one of the proposed elements of a general definition of CAL in both countries: 'extravasation of contrast after rectal enema at the CT-scan'. Another two were found relevant according to Dutch surgeons: 'necrosis of the anastomosis found during reoperation', and 'a radiological collection with percutaneous drainage'. No consensus was found for all other proposed elements that may be included in a general definition.

\section{Conclusion}

There is no universally accepted definition of colorectal anastomotic leakage in the Netherlands and China. Diagnosis of CAL based on clinical manifestations remains a point of discussion in both countries. Dutch surgeons are more likely to report 'subclinical' leaks as CAL, which partly explains the higher reported Dutch CAL rates. 


\section{Introduction}

Colorectal anastomotic leakage (CAL) remains gastrointestinal surgeons' most feared complication, despite important improvements in perioperative care and the development of novel surgical techniques. It is associated with high rates of morbidity and mortality ${ }^{1,2}$, poor patient quality of life $e^{3}$ and an increase of healthcare costs ${ }^{4,5}$. Since CAL influences the direct postoperative course and has recently been proven to impact oncological outcome as well ${ }^{6-8}$, it is frequently used as an outcome measure in clinical studies. However, the CAL rates vary considerably in international literature: from 1.5 to $23 \%^{9,10}$. Large variations in leakage rates have been reported between studies published by Western and Asian research groups, in which the reported incidence of CAL in Asian publications is substantially lower ${ }^{11,12,5,13,14}$. Such differences can be partly explained by the variations of operation technique, tumor location and patient characteristics ${ }^{15,16}$. However, little attention has been paid to potential differences in the CAL definition and the available methods of diagnosis.

Although CAL is sometimes defined as "a defect in the bowel wall at the anastomotic site, leading to communication of intra- and extraluminal compartments" ${ }^{17}$, this definition translates rather difficult to the clinical situation. Therefore, many authors formulate new definitions or diagnostic criteria in their studies, which usually include clinical and radiological features ${ }^{18}$, and the impact of a leak on the treatment plan. However, since the pathophysiology of anastomotic leakage is multifactorial, the manifestation of a clinical leak can be rather variable ${ }^{15}$. Furthermore, due to the increased use of (routine) diagnostics such as CT or contrast enema, "radiological" leaks that do not eventually influence patient management are diagnosed more often. These factors complicate comparison of study results, and weaken the reliability of further analyses. This in turn hampers the construction of evidence-based guidelines on patient management and surgical technique.

Clearly, there is a need for a generally accepted and practical definition for CAL and its diagnostic criteria to serve as a template for future research on CAL and the clinical decision-making process ${ }^{19}$. Several surveys have been performed to reach consensus regarding the definition of $\mathrm{CAL}$, however, most of them were restricted to a single country $^{19}$. We hypothesize that the aforementioned reported differences in incidence rates between Asian and Western countries can partly be explained by differences in the definitions and diagnostic methods used. The aim of this study is therefore to determine the level of consensus regarding different aspects of a general definition of colorectal anastomotic leakage within and between populations of Chinese and Dutch colorectal 
surgeons, who can be considered good representatives of the East and West, respectively.

\section{Materials and methods}

An online survey was performed among colorectal surgeons from the Netherlands and China. In the Netherlands, the survey was constructed and run through an online database using SurveyMonkeyTM Palo Alto, CA, USA. Colorectal surgeons in the Netherlands were identified from the contacts section of the colorectal subdivision of the Dutch Society of Gastro Intestinal Surgery (NVGIC): the Taskforce Coloproctology (WCP). Within this subdivision, 141 both senior and junior colorectal surgeons were identified. Respondents were invited to partake in the online survey by email. Dutch surgeons completed the questionnaire between May and June 2015.

In China, the survey was conducted on the platform provided by DXY (www.dxy.cn), which is the largest medical website in China with more than one million registered medical users. An invitation was sent to all the registered colorectal surgeons to invite them to participate a five-minute survey. Due to a relatively large number of registered users, the survey was designed to be terminated when 200 replies were received. Surgeons from Hong Kong, Macao, and Taiwan were not invited in this survey, since to the application of different medical systems in those areas. A demographic chart of the regions represented by the respondents can be observed in Figure 2.1.

The survey was divided into three major categories with questions addressing the general definition, and the clinical and radiological diagnosis of CAL. It was partly adapted from a previous study of Adams et al. ${ }^{20}$ and was initially constructed in English, and then translated to Dutch and Chinese by surgeons fluent in both English and Dutch and English and Chinese for the Dutch and Chinese by surgeons fluent in both English and Dutch, and English and Chinese for the Dutch and Chinese versions respectively, and checked for interpretation bias. Details of the English questionnaire are shown in Table 2.1 (See supplementary data for Dutch and Chinese version).

Category I mainly focused on the agreement of general definitions used in international literature ${ }^{20}$. Surgeons were asked to state whether 10 different clinical situations should or should not be included a general definition. Category II focused on clinical manifestations and its predictive value on CAL. A numeric scale with a grading from 1 (not predictive at all) to 10 (very predictive) was used to assess the agreement of the 
respondents' views on the clinical parameters. The parameters used were partially adapted from the Dutch Leakage Score (DULK) ${ }^{11}$. Category III consisted of four questions regarding the use of radiological examination and the influence of this diagnostic method on patient care. This third category was also partially adapted from Adams et al. $^{20}$. The last general question focused on surgeons' views regarding the cause of very early anastomotic leakage.

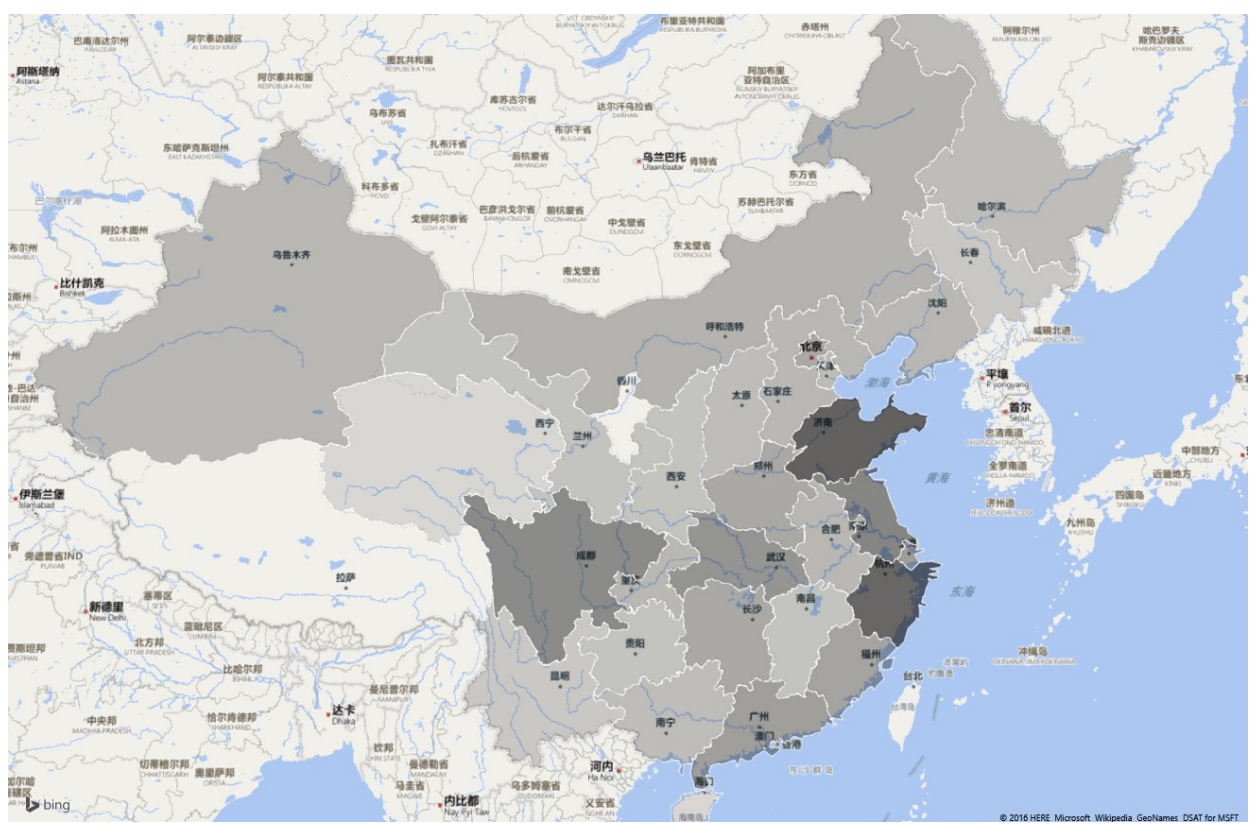

Figure 2.1 Demographic chart of the Chinese regions this survey covers. The gray scale reflects the number of participants in each region, varying from 21 from Zhejiang to 1 from Hainan. Correlating with the number of colorectal surgeons in each region, more surgeons from the east regions participated this survey. Tibet and Ningxia had no participants, which also corresponds to the fact that the number of surgeons is very limited compared to the east provinces. Due to the application of different medical systems, doctors from Hongkong, Macao, and Taiwan were not invited in this survey. 
Table 2.1 English questionnaire definition colorectal anastomotic leakage.

\begin{tabular}{lll}
\hline General definition & \\
\hline Do we have to consider the following findings as anastomotic leakage? & Yes & No \\
1 & Extravasation of contrast after rectal enema at the CT-scan \\
2 & Radiological collection around the anastomosis and no treatment \\
3 & Radiological collection around the anastomosis treated with antibiotics \\
4 & Radiological collection around the anastomosis treated with \\
5 & $\begin{array}{l}\text { percutaneous drainage } \\
6\end{array}$ & Necrosis of the anastomosis seen at reoperation \\
7 & Necrosis of the blind loop seen at reoperation \\
8 & Signs of peritonitis during reoperation \\
9 & Air bubbles around the anastomosis seen on a CT scan \\
10 & Free intra-abdominal air seen on a CT scan \\
\hline Clinical diagnosis
\end{tabular}

In what extent do the following clinical parameters contribute to the suspicion of colorectal anastomotic leakage? Please note the relevance on a numeric scale of 0-10:

1 Increased C- reactive protein (CRP)

2 Increased leukocytes

3 Tachycardia

$4 \quad$ Increased respiratory rate

5 (Sub-) febrile temperature

6 Postoperative ileus ( $>4$ days)

7 Deterioration in clinical condition

8 Abdominal pain, other than wound pain

\section{Radiological diagnosis}

Answer the following questions using percentages (0\% = never, $100 \%$ = always)

1 In how many percent of patients with clinical suspicion of anastomotic leakage do you \% perform radiodiagnostics?

2 In how many percent of patients with clinical suspicion of anastomotic leakage do \% radiodiagnostics change your treatment policy?

3 In how many cases did the CT scan report no anastomotic leakage while there finally \% was an anastomotic leakage.

4 In how many percent of cases do you consider a reoperation without previous \% radiodiagnostics?

Early anastomotic leakage

In your opinion, is 'very early (<3 days) anastomotic leakage the result of technical failure?

1 Yes

2 No

\section{Definitions}

Very early anastomotic leakage was defined as leakage occurring within the first 3 days post surgery. Postoperative ileus was defined as an interval of more than 4 days from surgery until passage of flatus or stool and the tolerance of an oral diet ${ }^{21}$. Blind loop was defined as a bypassed loop of bowel after the construction of an end to end or end to side bowel anastomosis. 


\section{Statistics}

Basic descriptive statistics were used to summarize data for the online survey. Consensus was defined as $>80 \%$ agreement between respondents on various statements, as described by Duncan et al. ${ }^{22}$. If less than $80 \%$ of respondents deemed the statements important, it was stated that no consensus was reached. Graphical depictions of information were used where appropriate to facilitate interpretation of data. Chi square test or Mann-Whitney test were applied with proper indications. A p-value smaller than 0.05 was considered to indicate statistical significance.

\section{Results}

Of the 141 colorectal Dutch surgeons that were invited to partake in the online survey, 62 respondents accepted the invitation, and 59 completed the survey, resulting in a $42 \%$ response rate and $95 \%$ survey completion. In total, 100\% of 201 questionnaires received from Chinese surgeons were completed. A demographic chart of the regions represented by the respondents can be observed in Figure 2.1, as it shows that this survey covers $96.8 \%$ (30/31, Hong Kong, Macao, Taiwan not included) of provinces and areas of China.

Consensus was found on only one clinical situation proposed as an element of a general definition in both countries: 'extravasation of contrast on enema' (Figure 2.2), and in the Netherlands on two additional elements: radiological collection for which percutaneous drainage was needed (50/59 respondents, 85\%) and necrosis of the anastomosis visible upon reintervention (51/59 respondents, 86\%). For all other items on the available general definitions, clinical and radiological diagnosis of CAL, no consensus was found. Scores were significantly different between China and the Netherlands for the following elements: radiological collection treated conservatively $(21 \%$ vs. $39 \%$ respectively $\mathrm{P}=0.010$ ), necrosis of the blind loop on reintervention ( $41 \%$ vs. $69 \%$ respectively, $\mathrm{P}<0.001)$, and for air surrounding the anastomosis on CT-scan (65\% vs. $44 \%$ respectively, $\mathrm{P}=0.004)$. 


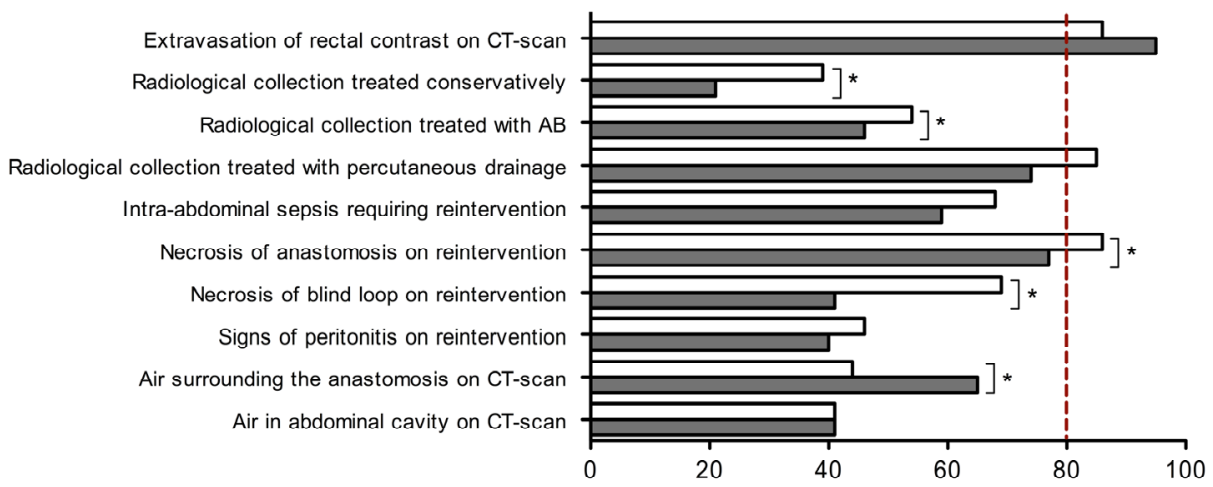

Figure 2.2 Percentage of respondents in agreement to general definitions of colorectal anastomotic leakage in the Netherlands (white bars) and China (dark grey bars). The dotted line indicates the $80 \%$ consensus threshold for the different statements. An asterisk indicates a significant $(P<0.05)$ difference between percentages of agreement of Dutch and Chinese surgeons.

Grades given for the clinical parameters are shown in Figure 2.3 for both China and the Netherlands. Clinical deterioration, increased CRP, tachypnea and tachycardia were seen as most contributory for the clinical suspicion of CAL in the Netherlands, and were given a weighed score of 7.83, 7.457 .13 and 7.13 respectively (Table 2.2). In China clinical deterioration and abdominal pain other than wound pain were deemed most attributable for the suspicion of anastomotic leakage in the direct postoperative period, with scores of 6.67 and 6.61 respectively. Increased plasma concentration of C-reactive protein received the lowest score of all parameters in China: 4.35 , while in the Netherlands this was deemed more sensitive $(7.45, \mathrm{P}<0.001)$. Upon categorization of the grades for the value of clinical parameters into different categories of the numeric scale: disagree (0-3), neutral (4-6) and agree (7-10), most surgeons from both countries (45-59\% of surgeons for each parameter) remained neutral towards the added value of specific clinical parameters during the postoperative course.

The data on radio diagnostics are shown in Table 2.3. The majority of Chinese and Dutch surgeons perform radio diagnostics upon clinical suspicion of a leak. The distribution of the answers over the different classifications, however, was significantly different between the two nationalities (Chi square test, $\mathrm{P}=0.020$ ). Expected false-negative rates for CT-scans were equal for surgeons in both countries. A significantly larger portion of the Chinese colorectal surgeons $(25.4 \%$ compared to $13.6 \%, P<0.001)$ would consider performing a reoperation for the suspicion of colorectal anastomotic leak without 
performing radiological diagnostics. The distribution of the scores differs significantly between countries as to in how many cases a reoperation is considered without previous radio diagnostics (Chi square test, $\mathrm{P}=0.002$ ).

Concerning the question about early CAL, 90.6 percent of the Chinese surgeons agreed that the cause of such should be considered a technical failure, whilst only $70,4 \%$ of the Dutch colorectal surgeons agreed to this statement $(P<0.001)$.

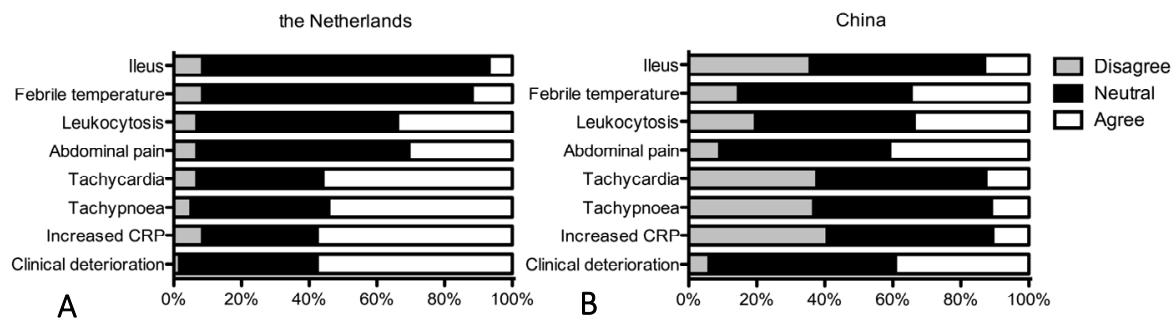

Figure 2.3 Distribution of categorized scores for the value clinical parameters in the direct postoperative phase. Comparison between the Netherlands (A) and China (B). Scores are divided into three categories: numeric scales ranging from 0-3 are depicted in grey (disagree), 4-6 depicted in black (neutral), and numeric scales ranging from 7-10 (agree) are depicted in white.

Table 2.2 Sensitivity scores of clinical parameters for the suspicion of anastomotic leakage in the direct postoperative period in China and The Netherlands.

\begin{tabular}{lccccc}
\hline & \multicolumn{2}{c}{ China } & \multicolumn{2}{c}{ The Netherlands } & SD \\
Clinical Parameter & Score & SD & Score & P-value \\
\hline Increased CRP & 4.35 & \pm 2.466 & 7.45 & \pm 1.871 & $<0.001$ \\
Leukocytosis & 5.96 & \pm 2.596 & 6.53 & \pm 1.824 & 0.095 \\
Tachycardia & 4.55 & \pm 2.411 & 7.13 & \pm 1.937 & $<0.001$ \\
Tachypnea & 4.46 & \pm 2.244 & 7.13 & \pm 1.937 & $<0.001$ \\
Febrile temperature & 6.23 & \pm 2.281 & 5.86 & \pm 1.963 & 0.207 \\
Postoperative ileus & 4.47 & \pm 2.363 & 5.76 & \pm 1.679 & $<0.001$ \\
Clinical deterioration & 6.67 & \pm 2.033 & 7.83 & \pm 1.205 & $<0.001$ \\
Abdominal pain & 6.61 & \pm 2.247 & 6.74 & \pm 1.835 & 0.659 \\
\hline
\end{tabular}


Table 2.3 Surgeons' opinion regarding the value of radio diagnostics in the diagnosis of colorectal anastomotic leakage.

\begin{tabular}{|c|c|c|c|}
\hline & China (\%) & The Netherlands (\%) & P-value \\
\hline \multicolumn{4}{|c|}{$\begin{array}{l}\text { In how many percent of patients with clinical suspicion of anastomotic leakage do you perform radio } \\
\text { diagnostics? }\end{array}$} \\
\hline Responders, no. (\%) & $202(100 \%)$ & $55(93 \%)$ & \\
\hline $0-20 \%$ & 3.0 & 0 & \\
\hline $21-40 \%$ & 6.4 & 0 & \\
\hline $41-60 \%$ & 6.9 & 1.8 & \\
\hline $61-80 \%$ & 24.3 & 16.4 & \\
\hline $81-100 \%$ & 59.4 & 81.8 & \\
\hline Average & 83.3 & 91.5 & 0.285 \\
\hline
\end{tabular}

In how many percent of patients with clinical suspicion of anastomotic leakage do radio diagnostics change your treatment policy?

\begin{tabular}{lcc}
\hline Responders, no .(\%) & $202(100 \%)$ & $54(91.5 \%)$ \\
$0-20 \%$ & 10.9 & 13.0 \\
$21-40 \%$ & 9.9 & 5.6 \\
$41-60 \%$ & 27.7 & 44.4 \\
$61-80 \%$ & 30.2 & 25.9 \\
$81-100 \%$ & 26.7 & 11.1 \\
Average & 63.6 & 55.9 \\
\hline In how many cases did the CT scan report no anastomotic leakage while there finally was an anastomotic \\
leakage? & & \\
\hline Responders, no. (\%) & $202(100 \%)$ & $52(88.1 \%)$ \\
$0-20 \%$ & 40.6 & 51.9 \\
$21-40 \%$ & 29.2 & 28.8 \\
$41-60 \%$ & 25.2 & 15.4 \\
$61-80 \%$ & 4.0 & 1.9 \\
$81-100 \%$ & 1.0 & 1.9 \\
Average & 31.8 & 28.7 \\
\hline In how many percent of cases do you consider a reoperation without previous radio diagnostics? \\
\hline Responders, no (\%) & $202(100 \%)$ & $53(89.8)$ \\
$0-20 \%$ & 58.4 & 84.9 \\
$21-40 \%$ & 18.8 & 13.2 \\
$41-60 \%$ & 17.3 & 0 \\
$61-80 \%$ & 4.5 & 0 \\
$81-100 \%$ & 1.0 & 1.9 \\
Average & 25.4 & 13.6 \\
\hline
\end{tabular}

\section{Discussion}

Despite extensive research in the field of colorectal anastomotic leakage, no international consensus regarding a practical definition exists, which limits transparency and comparison of study outcomes. Several definitions of CAL have been proposed during the last decades ${ }^{18,23}$, but review of the literature shows that newly published papers fail to adopt these definitions ${ }^{24}$. Instead, authors seem to prefer to use their own 
definitions or no definition at all ${ }^{24}$. It could be postulated that these previously proposed definitions were not yet implemented in clinical practice and (retrospective) research because of limited awareness of the existence of such a definition and/or lack of support from a large expert group.

Reports from Asian studies show CAL rates that are substantially lower than those reported by Western research groups ${ }^{25}$. This could partially be explained by demographic differences that exist in patient population, availability and use of diagnostic tools, or how perioperative care is structured. Another explanation could be that Chinese surgeons only report a leak as such in case a reintervention is required.

On the other hand, despite the lower prevalence of obesity in Asian countries, rates of diabetes mellitus type II and metabolic syndrome are relatively high due to ethnic and genetic factors. Indeed, Asians account for $60 \%$ of diabetes mellitus cases worldwide ${ }^{26}$, which is considered an important risk factor for $\mathrm{CAL}^{27,28}$. Furthermore, the most common location of colorectal tumors in the Asian population is the left hemicolon ${ }^{16,29}$. compared to the Western population, in which the predominant side is the right ${ }^{29,30}$. Literature shows a significantly higher CAL risk for surgeries on colorectal tumors located in the left hemicolon ${ }^{31}$. These regional differences therefore fail to completely explain the variation in reported CAL rates. It is very likely that important regional differences exist as to what is considered an anastomotic leak, i.e. Asian surgeons may report a leak mostly when a reintervention is required, while the Western surgeons may report latent leaks. In order to gain more insight in these differences in views, the present survey was conducted both in China and in the Netherlands, countries that are considered to be representative for their continent.

In the first part of the survey, surgeons were asked whether different statements including clinical and radiological signs and interventions regarding CAL should be considered anastomotic leakage. Of ten statements, only one was deemed as CAL by more than $80 \%$ of respondents in both countries: 'Extravasation of contrast after rectal enema visible on CT-scan'. This is generally considered a radiological hallmark sign for anastomotic leakage after left sided colorectal surgery and should naturally be included in a general definition. Moreover, other important and evident CAL signs including "Radiological collection around the anastomosis treated with percutaneous drainage" and "Necrosis of the anastomosis seen at reoperation" received more than $80 \%$ positive responses in the Netherlands, however, not in China, and thus were not considered as consent according to the predetermined criteria. Despite this, the majority of the Chinese surgeons also agreed on these items and their answers did not differ 
significantly from those of their Dutch colleagues. In conclusion, it seems that for the evident signs of CAL, the majority of surgeons from both countries have quite similar views.

"Radiological collection treated conservatively" is only considered as CAL in $21 \%$ of the Chinese surgeons (versus 39\% in the Netherlands), which is almost a consensus of NOT diagnosing CAL. On the contrary, it is at least remarkable that in current grading systems, a radiological collection is considered anastomotic leakage. As such this is reported as a Grade-A CAL according to the International Study group of Rectal Cancer (ISREC) ${ }^{18}$ and Grade I-II CAL according the Clavien-Dindo Scale.

Despite the fact that only a minority of Dutch surgeons consider conservatively treated radiological collections as CAL, these numbers are higher than the Chinese. These differences in views regarding the subclinical signs of CAL may eventually lead to a significantly higher reported CAL rate in the Dutch studies than the Chinese ones. However, considering the fact that more than $30 \%^{32}$ of the CAL do not require invasive intervention, the treatment provided by surgeons from both countries may eventually be similar, i.e. leading to a similar intervention rate for the complication. To rule out the reporting difference in this regard, one solution is to report complications with a ClavienDindo score higher than IIla, which actually is also commonly accepted and applied in recent studies.

The second part of the survey focused mainly on clinical markers and parameters for CAL. Early clinical diagnosis of CAL remains a challenge for surgeons worldwide. Many clinical symptoms and biomarkers have been suggested as early signs of $\mathrm{CAL}^{33-36}$. However, previous studies of these parameters have shown that almost none of these parameters yield sufficient diagnostic accuracy that allows a confirmative diagnosis ${ }^{37}$. This explains our findings that most surgeons do not rely their diagnosis of CAL based on these parameters, which results in a relatively low score of their contribution to the suspicion of CAL. Surgeons from both countries deemed 'deterioration of clinical condition' as an important symptom of CAL, which further accentuates the complexity of CAL diagnosis based on its clinical manifestations. We believe the surgeons' opinions indeed reflect the unsatisfactory status of CAL diagnosis, which stresses the need for further research in this field ${ }^{38}$. However, important differences exist between the two countries. Although surgeons from both countries agreed about the predictive value of higher temperature, abdominal pain other than wound pain and increased leukocytes, more than half of the clinical parameters scored significantly lower in China than the Netherlands. Although these abnormal clinical manifestations are indeed very common 
after gastrointestinal surgery ${ }^{39}$, it seems they are considered less suggestive by the Chinese surgeons.

The third part of the survey focused on radiological tools used in the diagnosis of CAL. Based on the present data, the majority of the surgeons in both countries would perform radiological examination on patients in whom CAL was suspected (these numbers are slightly higher in the Netherlands), and more than half of the treatment plans would be changed after the imaging. In this regard, although differences have been found in in the views of Chinese and Dutch surgeons regarding the definition of $\mathrm{CAL}$, the treatment they provide is similar. However, our data also show that surgeons from both countries do not blindly rely on the results from radio diagnostics. Instead, they state that in approximately $30 \%$ of the cases in which CAL is suspected, CAL is eventually diagnosed even though the radiological report is negative. This correlates with previously reported false negative rates of $\mathrm{CT}$ scans ${ }^{40}$. Experience with inaccurate CT scan reports may be a reason for surgeons to consider reoperation without affirmative CT results, which according to the data, is being done in about $25 \%$ of cases.

Further research and education may facilitate the achievement of international consensus. However, definition without considerations of the practical issues in different regions is unlikely to gain sufficient popularity. In 2010, The international Study Group of Rectal Cancer (ISREC) proposed a graded system for the diagnosis and treatment of $\mathrm{CAL}^{18}$. Grade A CAL refers to anastomotic leakage for which no active therapeutic intervention is required. It seems that this grade correlates with the second statement "Radiological collection surrounding the anastomosis treated conservatively" that, according to the majority of both Dutch and Chinese surgeons is not classified as CAL. This discrepancy between an established definition and the views of colorectal surgeons could partly explain why the ISREC definition has not been adopted in practice and science. In accordance with that, our survey clearly demonstrates how different practice may influence surgeons' opinion.

For example, in the Netherlands the Enhanced Recovery After Surgery (ERAS) program has been widely adapted for over years, and recommends no abdominal drainage after surgery, In China, on the contrary, ERAS is less commonly implemented, while intraabdominal drainage is often left in situ for longer period after surgery. Moreover, CT imaging is less commonly used for radio-diagnostics of CAL, and laboratory analysis by means of CRP is not yet included into a routine practice in many rural areas. This could explain why increased CRP was deemed least contributory in the diagnostic process in 
the present survey. These points, though small, significantly influenced the results, and would certainly influence the applicability of a proposed CAL definition.

To embed a successful definition in clinical practice, research on CAL would greatly benefit from establishing a uniform definition and recording in national databases. We will therefore continue to perform an extensive and systematic literature review. The results from that review and the consensus assessment described in this paper will lead to an international Delphi analysis, that will allow us to reach consensus on a new definition proposal that will be supported by a large panel of experts. We sincerely welcome others to participate in this further research, in order to formulate a new definition based on joint experience and opinions.

The most important limitations of the study are the following. The content of questionnaires is always susceptible to researcher imposition and there may be a level of subjectivity in the answers given. Furthermore, the relatively low numbers of respondents from both countries will have a negative influence of the generalizability of study results. Finally, the original questionnaire was constructed in English and translated into Dutch and Chinese, which could introduce bias and weaken the validity of comparisons between the countries. Finally, as some of the clinical parameters used in the questionnaire were derived from the DULK-score, which was constructed and validated in the Netherlands, it is plausible that the Dutch participants scored similarly on these items because they were familiar with the content of the DULK-score, or because they have been (in)directly involved in the construction of the scoring system. However, the use of the DULK-score has not remained limited to the Netherlands, and it is unknown whether the subset of Dutch surgeons familiar with the DULK-score is higher than the number of Chinese surgeons who use this score routinely, and whether this difference is large enough to alter the data significantly.

\section{Conclusion}

No international consensus of a practical definition of CAL is yet available, which limits transparency and comparison of published results. The present international online survey proves the inconsistent views as to what is considered CAL among surgeons in the Netherlands and China, and shows large differences between countries. Dutch surgeons are more likely to report 'subclinical' leaks as CAL, which partly explains the higher reported Dutch CAL rates. Surgeons from both countries rely on radiological diagnostics and laboratory parameters in the decision-making process, but are well 
aware of the limitations of these diagnostic aids. A Delphi analysis within a representative panel of colorectal surgeons is desired to develop a widely accepted definition of colorectal anastomotic leakage. 


\section{References}

1. Kirchhoff P, Clavien PA, Hahnloser D. Complications in colorectal surgery: risk factors and preventive strategies. Patient Saf Surg 2010;4(1):5.

2. Bertelsen $\mathrm{CA}$, Andreasen $\mathrm{AH}$, Jorgensen $\mathrm{T}$, et al. Anastomotic leakage after curative anterior resection for rectal cancer: short and long-term outcome. Colorectal Dis 2010;12(7 Online):e76-81.

3. McArdle CS, McMillan DC, Hole DJ. Impact of anastomotic leakage on long-term survival of patients undergoing curative resection for colorectal cancer. Br J Surg 2005;92(9):1150-4.

4. Govaert JA, Fiocco M, van Dijk WA, et al. Costs of complications after colorectal cancer surgery in the Netherlands: Building the business case for hospitals. Eur J Surg Oncol 2015;41(8):1059-67.

5. Hammond J, Lim S, Wan Y, et al. The burden of gastrointestinal anastomotic leaks: an evaluation of clinical and economic outcomes. J Gastrointest Surg 2014;18(6):1176-85.

6. Law WL, Choi HK, Lee YM, et al. Anastomotic leakage is associated with poor long-term outcome in patients after curative colorectal resection for malignancy. J Gastrointest Surg 2007;11(1):8-15.

7. Kulu Y, Tarantio I, Warschkow R, et al. Anastomotic leakage is associated with impaired overall and disease-free survival after curative rectal cancer resection: a propensity score analysis. Ann Surg Oncol 2015;22(6):2059-67.

8. Mirnezami A, Mirnezami R, Chandrakumaran K, et al. Increased local recurrence and reduced survival from colorectal cancer following anastomotic leak: systematic review and meta-analysis. Ann Surg 2011;253(5):890-9.

9. Bakker IS, Grossmann I, Henneman D, et al. Risk factors for anastomotic leakage and leak-related mortality after colonic cancer surgery in a nationwide audit. Br J Surg 2014;101(4):424-32.

10. McDermott FD, Heeney A, Kelly ME, et al. Systematic review of preoperative, intraoperative and postoperative risk factors for colorectal anastomotic leaks. Br J Surg 2015;102(5):462-79.

11. den Dulk M, Witvliet MJ, Kortram K, et al. The DULK (Dutch leakage) and modified DULK score compared: actively seek the leak. Colorectal Dis 2013;15(9):e528-33.

12. Buchs NC, Gervaz P, Secic M, et al. Incidence, consequences, and risk factors for anastomotic dehiscence after colorectal surgery: a prospective monocentric study. Int J Colorectal Dis 2008;23(3):265-70.

13. Law WL, Chu KW. Anterior resection for rectal cancer with mesorectal excision: a prospective evaluation of 622 patients. Ann Surg 2004;240(2):260-8.

14. Konishi T, Watanabe T, Kishimoto J, et al. Risk factors for anastomotic leakage after surgery for colorectal cancer: results of prospective surveillance. J Am Coll Surg 2006;202(3):439-44.

15. Sparreboom CL, $\mathrm{Wu} \mathrm{ZQ}$, Ji JF, et al. Integrated approach to colorectal anastomotic leakage: Communication, infection and healing disturbances. World J Gastroenterol 2016;22(32):7226-35.

16. Goh KL, Quek KF, Yeo GT, et al. Colorectal cancer in Asians: a demographic and anatomic survey in Malaysian patients undergoing colonoscopy. Aliment Pharmacol Ther 2005;22(9):859-64.

17. Buscail E, Blondeau V, Adam JP, et al. Surgery for rectal cancer after high-dose radiotherapy for prostate cancer: is sphincter preservation relevant? Colorectal Dis 2015;17(11):973-9.

18. Rahbari NN, Weitz J, Hohenberger W, et al. Definition and grading of anastomotic leakage following anterior resection of the rectum: a proposal by the International Study Group of Rectal Cancer. Surgery 2010;147(3):339-51.

19. Reinke CE, Showalter S, Mahmoud NN, et al. Comparison of anastomotic leak rate after colorectal surgery using different databases. Dis Colon Rectum 2013;56(5):638-44.

20. Adams K, Papagrigoriadis S. Little consensus in either definition or diagnosis of a lower gastro-intestinal anastomotic leak amongst colorectal surgeons. Int J Colorectal Dis 2013;28(7):967-71.

21. Vather R, Trivedi S, Bissett I. Defining postoperative ileus: results of a systematic review and global survey. J Gastrointest Surg 2013;17(5):962-72.

22. Duncan EA, Colver K, Dougall N, et al. Consensus on items and quantities of clinical equipment required to deal with a mass casualties big bang incident: a national Delphi study. BMC Emerg Med 2014;14:5.

23. Peel AL, Taylor EW. Proposed definitions for the audit of postoperative infection: a discussion paper. Surgical Infection Study Group. Ann R Coll Surg Engl 1991;73(6):385-8. 
24. Bruce J, H ZHKZ, Al-Khairy G, et al. Systematic review of the definition and measurement of anastomotic leak after gastrointestinal surgery. Br J Surg 2001;88(9):1157-68.

25. Cong ZJ, $\mathrm{Hu} \mathrm{LH}$, Bian ZQ, et al. Systematic review of anastomotic leakage rate according to an international grading system following anterior resection for rectal cancer. PloS One 2013;8(9):e75519.

26. Ramachandran A, Snehalatha C, Shetty AS et al. Trends in prevalence of diabetes in Asian countries. World J Diabetes 2012;3(6):110-7.

27. Lin X, Li J, Chen W, et al. Diabetes and risk of anastomotic leakage after gastrointestinal surgery. J Surg Res 2015;196(2):294-301.

28. Iancu C, Mocan LC, Todea-lancu D, et al. Host-related predictive factors for anastomotic leakage following large bowel resections for colorectal cancer. J Gastrointest Liver Dis 2008;17(3):299-303.

29. Qing SH, Rao KY, Jiang HY, et al. Racial differences in the anatomical distribution of colorectal cancer: a study of differences between American and Chinese patients. World J Gastroenterol 2003;9(4):721-5.

30. Rabeneck L, Davila JA, El-Serag HB. Is there a true "shift" to the right colon in the incidence of colorectal cancer? Am J Gastroenterol 2003;98(6):1400-9.

31. Sultan R, Chawla T, Zaidi M. Factors affecting anastomotic leak after colorectal anastomosis in patients without protective stoma in tertiary care hospital. J Pak Med Assoc 2014;64(2):166-70.

32. Joh YG, Kim SH, Hahn KY, et al. Anastomotic leakage after laparoscopic protectomy can be managed by a minimally invasive approach. Dis Colon Rectum 2009;52(1):91-6.

33. Bellows CF, Webber LS, Albo D, et al. Early predictors of anastomotic leaks after colectomy. Techn Coloproctol 2009;13(1):41-7.

34. Reisinger KW, Poeze M, Hulsewe KW, et al. Accurate prediction of anastomotic leakage after colorectal surgery using plasma markers for intestinal damage and inflammation. J Am Coll Surg 2014;219(4): 744-51.

35. Cini C, Wolthuis A, D'Hoore A. Peritoneal fluid cytokines and matrix metalloproteinases as early markers of anastomotic leakage in colorectal anastomosis: a literature review and meta-analysis. Colorectal Dis 2013;15(9):1070-7.

36. Agilli M, Aydin FN. Methodologic approach to accurate prediction of anastomotic leakage after colorectal surgery using plasma markers for intestinal damage and inflammation. J Am Coll Surg 2015;220(5):971.

37. Pedersen $\mathrm{T}$, Roikjaer $\mathrm{O}$, Jess $\mathrm{P}$. Increased levels of C-reactive protein and leukocyte count are poor predictors of anastomotic leakage following laparoscopic colorectal resection. Dan Med J 2012;59(12): A4552.

38. Daams F, Wu Z, Lahaye MJ, et al. Prediction and diagnosis of colorectal anastomotic leakage: A systematic review of literature. World J Gastrointest Surg 2014;6(2):14-26.

39. Erb L, Hyman NH, Osler T. Abnormal vital signs are common after bowel resection and do not predict anastomotic leak. J Am Coll Surg 2014;218(6):1195-9.

40. Doeksen A, Tanis PJ, Wust AF, et al. Radiological evaluation of colorectal anastomoses. Int J Colorectal Dis 2008;23(9):863-8. 



\section{Chapter}

Use of colorectal anastomotic leakage definitions in

literature: results of a systematic review and

recommendations for future reporting

Audrey CHM Jongen, Stefanus J van Rooijen, Valérie NE Schuermans, Zhouqiao Wu, Rudi MH Roumen, Gerrit D Slooter, Nicole D Bouvy, Taskforce Anastomotic Leakage

Submitted 


\section{Abstract}

\section{Background}

Anastomotic leakage is the most feared complication following colorectal surgery, but a common definition is still lacking. This complicates comparison of study outcome.

Objective

The study aimed to gain insight in the use of different definitions in the literature and how this affects leakage rates. The study further focuses on availability of data in the included papers.

Data sources

A systematic literature search was performed in Medline and Embase databases.

Study selection

All retrospective and prospective papers discussing colorectal surgery with the construction of an anastomosis, published between January 1990 and January 2016, were reviewed for the presence of a definition of CAL and/or details of clinical or radiological assessment.

Main Outcome Measures

A total of 361 manuscripts containing a definition on colorectal anastomotic leakage were used. Definitions were clustered based on the description of clinical and radiological signs and the consequences of a leak.

Results

A vast number $(73,9 \%)$ of papers published on this subject did not include a definition of colorectal anastomotic leakage. Leakage rates vary strongly between rectal and colon anastomoses $(7,48$ and $5,32 \%$, respectively) and with the type of definition used. Nineteen percent of authors used a grading system to illustrate the severity of the anastomotic leaks. Reporting of data regarding the operative procedure and the postoperative period varied substantially between studies.

Limitations

The most important limitation of this study is the heterogeneity between the included studies and the varying presentation of data, which makes comparing of data rather difficult.

\section{Conclusion}

The present review shows the lack of a commonly used definition of colorectal anastomotic leakage. This systematic review provides insight in the different components of definitions that might serve as the basis of a Delphi-based proposal for a novel definition. The authors believe that implementation of a graded system with treatment recommendations will enhance uniformity of patient care and may lead to decreased treatment delay. 


\section{Introduction}

Colorectal anastomotic leakage (CAL) remains the most feared complication after colorectal surgery with a reported incidence of $1.5-23 \%{ }^{1,2}$. CAL substantially adds to the morbidity and mortality rates and thereby decreases patients' health-related quality of life (HRQoL) $)^{3-7}$. Compared to a normal postoperative course, the high number of reoperations and the associated increased length of hospital stay lead to a fivefold increase in expenditures on health care ${ }^{8}$. Furthermore, evidence arises from recent literature that CAL impacts the oncological prognosis, leading to an increased local recurrence and a decreased disease-specific survival ${ }^{9,10}$. Despite the large number of experimental and clinical studies conducted on this subject, and although CAL is commonly used as an outcome measure in these reports, no consistent definition of CAL is applied in literature ${ }^{11}$.

General definitions such as 'a defect of the intestinal wall at the anastomotic site leading to a communication between the intra and extra luminal compartments' ${ }^{12}$ or 'the leak of luminal content from a surgical joining between 2 hollow viscera' ${ }^{13}$ can be applied in case the leak is evident. However, this definition is more difficult to apply when a patient presents with atypical symptoms, which is often the case ${ }^{14}$. Due to the lack of a generally accepted definition of CAL, reported leakage rates vary significantly, which complicates comparison of study outcomes and comparison of quality of care in individual institutions. The use of (inter)national registration systems could potentially yield very large patient populations for database studies, and would therefore positively influence the impact of the presented results. However, the application of these registration systems for scientific research is also limited because of the aforementioned issues. Reinke et al. evaluated the ability of two different registration systems, an administrative and a clinical registry, to identify anastomotic leaks, and found that both types of databases had acceptable specificity but poor sensitivity for diagnosis of $\mathrm{CAL}^{15}$. There is an obvious need for an internationally accepted definition for both colon and rectal anastomotic leakage that will serve as a template for future research and to improve clinical decision-making.

Several definitions have been proposed in the past decades ${ }^{11,16}$. However, none of the suggested definitions functions as leading in current literature. We believe that this lack of acceptance is mainly due to the lack of an expert panel supporting the construction of these definitions. Our research team performed a consensus assessment among Dutch and Chinese colorectal surgeons and concluded there was no national or international consensus on what should comprise a general definition of $\mathrm{CAL}^{17}$. The aim of the present 
systematic review is therefore to gain insight in the use of different components of definitions in the literature, and how this effects reported leakage rates. Furthermore, the review focuses on the availability of data in the included papers, as this is also a large contributing factor as to why it is difficult to compare results from different studies. The findings of this study will eventually serve as the basis of a future Delphi-based proposal for a novel and widely accepted definition of CAL.

\section{Materials and methods}

An extensive systematic literature search in the biomedical databases of Medline and Embase was performed in January 2016 in accordance with the guidelines as presented in the PRISMA statement. All retrospective and prospective papers discussing colorectal surgery with the construction of an anastomosis, published between January 1990 and January 2016, in which anastomotic leakage was a primary or secondary outcome measure, were reviewed for the presence of a definition of CAL and/or details of clinical or radiological assessment. No restrictions were placed on the type of surgery or the indication of surgical resection (i.e., malignant or benign disease). The following papers were excluded from review: reviews, meta-analyses, articles discussing upper GI-surgery and animal studies.

The search that was used was as follows: Search ()(()((("Anastomotic Leak"[Mesh]) OR colorectal anastomotic leakage) OR colorectal anastomotic leak) OR anastomotic dehiscence colorectal) OR anastomotic leakage) OR anastomotic leak) OR anastomotic dehiscence)) AND (((rectum) OR colon) OR colorectal).

Definitions that were found were assessed for the presence of clinical and radiological diagnostic methods, grading systems and the clinical usability of the definition. The definitions were clustered into 11 categories based on the description of clinical and radiological signs and the consequences of a leak (i.e. whether radiological or surgical intervention was required) as part of the definition, in order to clarify the differences between the identified definitions. The categories listed in Table 3.1 can be appreciated to increase in completeness, varying from, category 1 , which consists of reports that only include clinical symptoms in their definition of CAL, to category 8 , which includes all possible aspects of a presentation of CAL. The papers included in category 9 only deemed the CAL that was observed during reoperation to be proven, papers referring to the ISREC classification were clustered in category 10, whereas category 11 contains definitions that did not fit any of the aforementioned descriptions.

Additional information was extracted from the included papers, regarding the construction of the anastomosis (e.g. type of surgery, height of the anastomosis, 
presence of deviating ostomy), timing and method of diagnosis of CAL, treatment and outcome after diagnosis of CAL, as well as signs and symptoms that were described in the diagnosis of CAL (fever, abdominal pain, ileus, fecal discharge from drain or wound, abnormal laboratory results etcetera).

Two researchers (AJ and SvR) conducted the selection process, and a third researcher (VS) was consulted in case of disagreement on the inclusion or exclusion of papers. A complete list of the included papers in this review can be found in the Supplementary Table S3.1. A two-sample test for proportions was used to calculate the difference in CAL rates between colon and rectal anastomoses.

\section{Results}

A total of 2938 abstracts and 1382 full-text articles were reviewed for the presence of a definition of colorectal anastomotic leakage and/or a description of clinical and radiological signs used for the diagnosis of CAL. 1021 papers $(73,9 \%$ of 1382) were excluded from analysis as they did not contain a definition of CAL. 361 papers met the inclusion criteria and were further used for data analysis. A total of 344 papers were used for the calculation of reported incidence rates, after the exclusion of papers using the same study population, protocol papers and manuscripts using matched cohorts. See Figure 3.1 for the flow diagram of the inclusion process. Figure 3.2 renders all included peer reviewed papers published between 1990 and 2015 on colorectal anastomotic leakage with and without the description of a definition. It shows that although CAL was a primary or secondary outcome in these studies, a vast number of publications did not include a definition for CAL. A total of 30 randomized controlled trials, 165 prospective studies and 152 retrospective studies were included. The following data were extracted from the included articles: study type, surgical procedure or intervention, definition of $\mathrm{CAL}$, reported leakage rates for colon and/or rectal anastomoses, median days postoperative of diagnosis of CAL, means of assessment of anastomotic integrity during surgery, number and percentages of deviating ostomies, and finally the description of clinical symptoms associated with CAL (e.g. fever, abdominal pain, leukocytosis). In order to clarify the differences between the identified definitions, they were then subclassified into 11 categories, based on combinations of the presence or absence of several components of the definition: clinical symptoms, radiological signs and/or findings during reintervention. See Table 3.1 for examples of the categorized definitions and the mean reported incidence rates of CAL associated with their classification. It can clearly be appreciated that these leakage rates vary strongly with the type of definition used for the diagnosis of CAL (leakage rates for rectal 
anastomoses varying between 2.4 and $12.3 \%$ for categories 9 and 11, respectively, and colonic leakage rates between 4.4 and $6.6 \%$ for categories 1 and 4 , respectively).

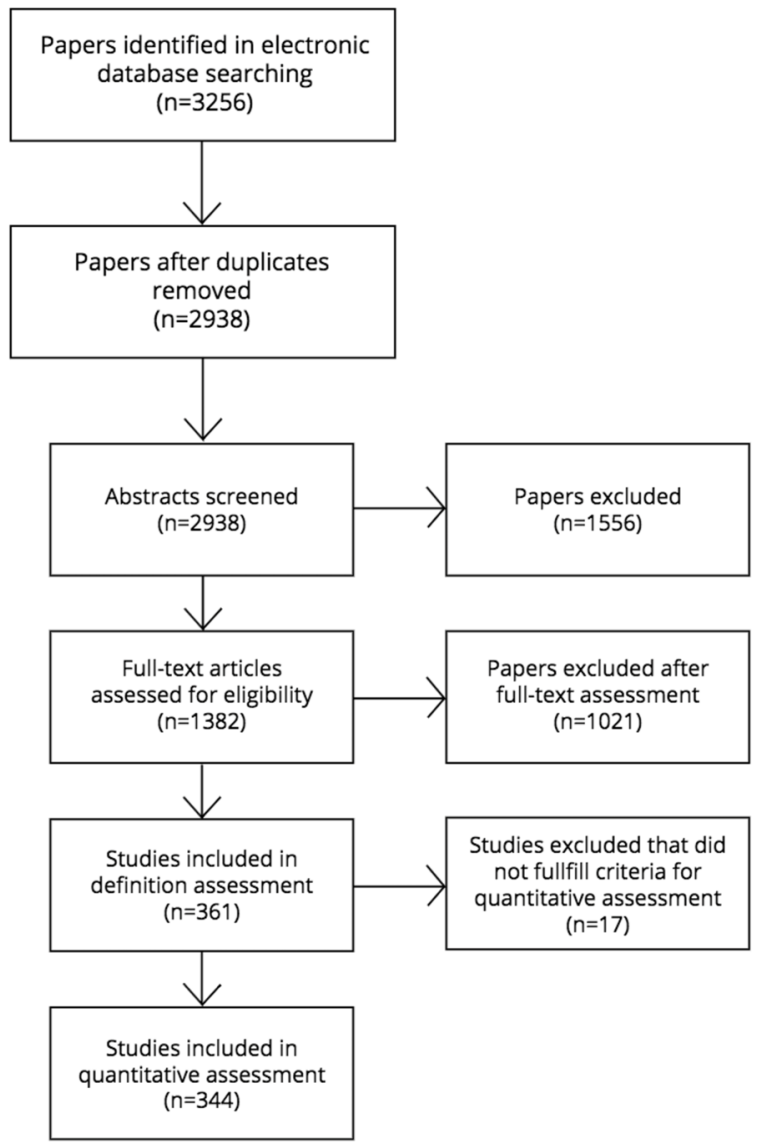

Figure 3.1 PRISMA flow diagram of selection process.

\section{Signs and symptoms}

A total of 238 papers (65.9\%) reported clinical signs and symptoms associated with colorectal anastomotic leakage, either as part of the formulated definition, or in the description of the method of diagnosis. The most commonly described clinical signs and symptoms were as follows: purulent or fecal discharge from drain, peritonitis, fever, purulent discharge from the rectum and abdominal pain (Table 3.2). 


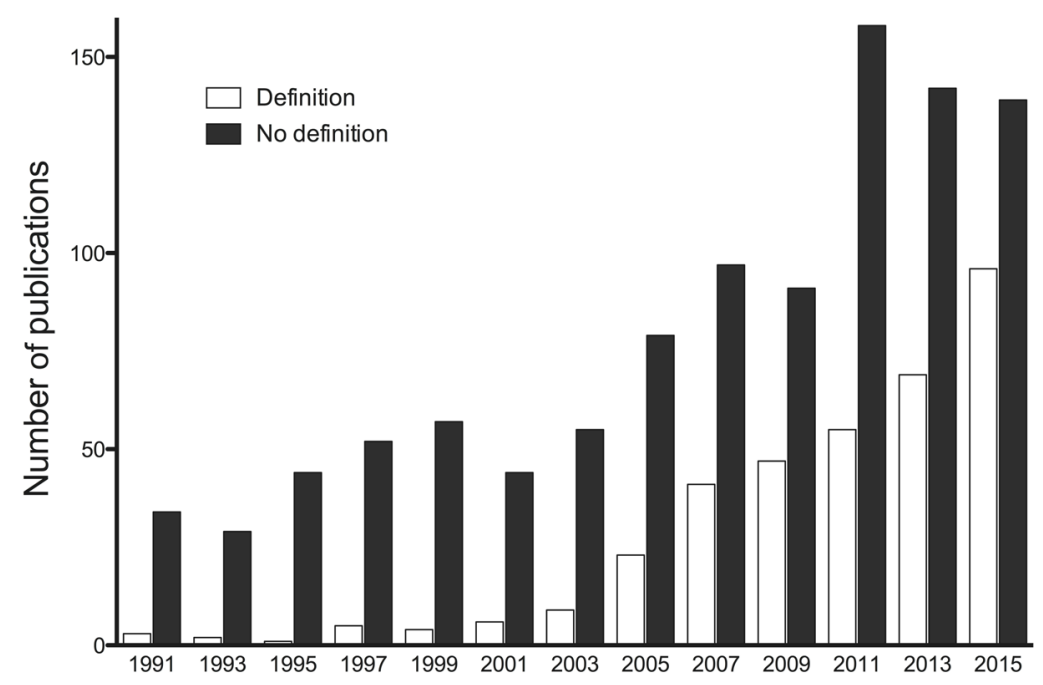

Figure 3.2 Papers published on the subject of colorectal anastomotic leakage with and without the formulation of a definition.

\section{Grading systems}

A small proportion of included papers (69 out of 361 papers, 19\%) explicitly stated the use of a grading system when formulating a definition (Table 3.3). The authors of 15 papers referred to the International Study group of Rectal Cancer (ISREC)classification $^{18-30}$, whereas 11 authors used the Clavien-Dindo classification ${ }^{31-41}$. The grading systems used in literature were further clarified in Table 3.3, and mainly divided the clinical cases based on clinical presentation, means of diagnosis or the resulting management of the complication.

\section{Colon versus rectum}

A comparison was made between leakage rates of rectal versus colon anastomoses, which showed that the rectal anastomoses were at significantly higher risk of developing a leak (7.48\% vs. 5.32\%, Odds Ratio: 0.71 (95\%Cl: 0.693-0,736), Z=-21.72, $\mathrm{P}$-value $=<0.001$ ). Only papers providing separate numbers for colonic and/or rectal anastomotic leakage were taken into account for this analysis ( $n=84$ for colonic CAL, $n=223$ for rectal $C A L$ ). Comparison of the reported rates of CAL in both anatomical regions further showed that the incidence rates have remained stable over the past decades (Figure 3.3). 
Table 3.1 Classification of definitions of colorectal anastomotic leakage (CAL); examples and \% CAL per classification.

\begin{tabular}{|c|c|c|}
\hline $\begin{array}{l}\text { Classification } \\
\text { (n) papers }\end{array}$ & Descriptions & $\begin{array}{l}\% \mathrm{CAL} \\
\text { mean (range) }\end{array}$ \\
\hline $\begin{array}{l}\text { 1. Clinical } \\
\text { diagnosis }(n=23)\end{array}$ & $\begin{array}{l}\text { The definition of anastomotic leakage was clinical and included: } \\
\text { peritonitis caused by leakage, discharge of feces from the abdominal } \\
\text { drain, rectovaginal fistula, leakage from all staple lines, pelvic } \\
\text { abscess without radiologically proven leakage mechanism. }{ }^{67} \\
\text { Anastomotic leakage was defined clinically by peritonitis resulting } \\
\text { from the leakage, with signs of acute abdomen, anal bleeding, or } \\
\text { suspicious quality of drainage. }{ }^{68}\end{array}$ & $\begin{array}{l}C=4.4(0-7.6 \%) \\
R=8.1(2.3-33)\end{array}$ \\
\hline $\begin{array}{l}\text { 2. Imaging } \\
\text { diagnosis }(n=11)\end{array}$ & $\begin{array}{l}\text { Colorectal anastomotic leakage was defined as a radiographically } \\
\text { confirmed extravasation of contrast at the anastomosis. }{ }^{69} \\
\text { An anastomotic leak was verified either by a radiographic enema } \\
\text { performed with computed tomography (CT) scan (standard for the } \\
\text { inpatient setting), X-ray, or by endoscopy. }\end{array}$ & $\begin{array}{l}C=N . A . \\
R=6.4(5.7-12.5)\end{array}$ \\
\hline $\begin{array}{l}\text { 3. Requiring } \\
\text { reintervention } \\
(n=34)\end{array}$ & $\begin{array}{l}\text { Anastomotic leakage was further defined, in line with recent } \\
\text { proposals, as a defect of the intestinal wall at the site of the } \\
\text { anastomosis requiring surgical or radiological intervention. }{ }^{31} \\
\text { Anastomotic leak was defined as minor leak requiring percutaneous } \\
\text { intervention or major leak requiring laparotomy. }\end{array}$ & $\begin{array}{l}C=5.4(0.7-7.1) \\
R=6.6(1.2-17.6)\end{array}$ \\
\hline $\begin{array}{l}\text { 4. Theoretical } \\
(n=20)\end{array}$ & $\begin{array}{l}\text { Anastomotic leakage defined as a defect in the intestinal wall at the } \\
\text { anastomotic site, which led to a linkage between intra- and } \\
\text { extraluminal compartments. } \\
\text { Anastomotic leakage was defined as the leak of luminal content } \\
\text { from a surgical join between two hollow viscera. }{ }^{73}\end{array}$ & $\begin{array}{l}C=6.6(2.3-10) \\
R=8.2(0-21.6)\end{array}$ \\
\hline $\begin{array}{l}\text { 5. Clinical } \\
\text { suspicion } \\
\text { confirmed by } \\
\text { imaging and/or } \\
\text { reoperation } \\
(n=71)\end{array}$ & $\begin{array}{l}\text { Anastomotic leakage was suspected due to fecal discharge from } \\
\text { wound or drain, fever, pelvic abscess, local peritonitis, discharge of } \\
\text { pus per anus, a CT scan was performed to confirm diagnosis. }{ }^{74} \\
\text { Anastomotic leakage was defined as the presence of clinical } \\
\text { symptoms such as fever or septicemia combined with the } \\
\text { occurrence of pelvic abscess, presence of rectal pus discharge, } \\
\text { formation of a rectovaginal fistula, or presence of peritonitis within } \\
30 \text { days after surgery, leading to a clinical and/or radiological } \\
\text { examination or repeat surgery to confirm the diagnosis. }\end{array}$ & $\begin{array}{l}C=6.1(1.8-13.2) \\
R=10.1(0.6-30.4)\end{array}$ \\
\hline $\begin{array}{l}\text { 6. Clinical and } \\
\text { imaging diagnosis } \\
(\mathrm{n}=96)\end{array}$ & $\begin{array}{l}\text { To define anastomotic leak both the clinical signs, symptoms (signs } \\
\text { of localized or generalized peritonitis, fecal discharge from the } \\
\text { wound and/or drain) and radiologic investigations are used }{ }^{76} \\
\text { The definition of anastomotic leakage included any clinical or } \\
\text { radiologic evidence of anastomotic dehiscence (such as discharge of } \\
\text { intestinal content through a drain), regardless of whether } \\
\text { reoperation or any other intervention was required. Additional tests } \\
\text { such as chest and abdominal computed tomography were } \\
\text { performed to assess leakage-related complications. }\end{array}$ & $\begin{array}{l}C=5.6(2.3-7.0) \\
R=8.2(1.5-22.5)\end{array}$ \\
\hline
\end{tabular}


Table 3.1 (continued)

\begin{tabular}{|c|c|c|}
\hline $\begin{array}{l}\text { Classification } \\
\text { (n) papers }\end{array}$ & Descriptions & $\begin{array}{l}\% \mathrm{CAL} \\
\text { mean (range) }\end{array}$ \\
\hline $\begin{array}{l}\text { 7. Imaging } \\
\text { diagnosis or at } \\
\text { reoperation } \\
(n=24)\end{array}$ & $\begin{array}{l}\text { A leak was defined as a breakdown of a colonic anastomosis } \\
\text { associated with an intra-abdominal collection identified either by } \\
\text { contrast radiographs or by the surgeon at the time of a subsequent } \\
\text { operation. } \\
\text { In case of imaging, leakage was considered to be present when free } \\
\text { air or contrast was visible around the anastomosis. In case of } \\
\text { relaparotomy, leakage was considered to be present when a } \\
\text { dehiscent anastomosis was visualized. }\end{array}$ & $\begin{array}{l}C=4.6(0-21) \\
R=9.0(5.2-21.1)\end{array}$ \\
\hline $\begin{array}{l}\text { 8. Clinical and/or } \\
\text { imaging and/or } \\
\text { at reoperation } \\
(n=64)\end{array}$ & $\begin{array}{l}\text { Anastomotic leakage was defined by at least one of the following } \\
\text { criteria: 1) an anastomotic defect noted on physical examination, } \\
\text { 2) an anastomotic defect confirmed in the operating room, 3) an } \\
\text { anastomotic defect seen on proctoscopy, 4) radiologic evidence of a } \\
\text { leak consisting of either a defect in the anastomosis and an adjacent } \\
\text { fluid collection, or stranding or the extravasation of rectal contrast } \\
\text { into the extraluminal space, or 5) clinical evidence of a leak such as } \\
\text { feculent output from a pelvic drain. } \\
\text { Clinical leak was defined as an anastomotic dehiscence verified by } \\
\text { any of the following: imaging [computed tomography (CT) or barium } \\
\text { enema], change in drainage material, operative intervention } \\
\text { showing drainage, endoscopic evidence of anastomotic dehiscence, } \\
\text { or signs of sepsis. }{ }^{32}\end{array}$ & $\begin{array}{l}C=5.4(1.7-20.3) \\
R=8.7(2.2-28.5)\end{array}$ \\
\hline $\begin{array}{l}\text { 9. Diagnosis only } \\
\text { at reoperation } \\
(n=3)\end{array}$ & $\begin{array}{l}\text { Anastomotic leakage was defined as the presence of bowel content } \\
\text { leaking from a defect in the anastomosis, identified at repeat } \\
\text { operation. } \\
\text { Patients with operatively confirmed anastomotic leak. }{ }^{[82]}\end{array}$ & $\begin{array}{l}C=N . A . \\
R=2.4(2.4-2.4)\end{array}$ \\
\hline 10. ISREC $(n=8)$ & $\begin{array}{l}\text { Leakages were classified into three groups: A) CAL requiring no } \\
\text { active therapeutic intervention B) AL requiring active therapeutic } \\
\text { intervention but manageable without re-laparotomy C) CAL } \\
\text { requiring re-laparotomy. Patients presented symptoms and signs of } \\
\text { leakage such as sepsis, fever, elevated white cell count and } \\
\text { C-reactive protein, perineal or pelvic pain, localized or generalized } \\
\text { peritonitis and discharge of blood or puss per rectum. CAL was } \\
\text { diagnosed by computed tomography (CT) with intravenous } \\
\text { contrast. }\end{array}$ & $\begin{array}{l}C=N . A . \\
R=7.8(5.6-17.7)\end{array}$ \\
\hline 11. Other $(n=7)$ & $\begin{array}{l}\text { Anastomotic leaks were categorized as either major clinical leaks } \\
\text { with signs of generalized peritonitis requiring emergency abdominal } \\
\text { reoperation or minor leaks diagnosed on clinical signs, generally } \\
\text { confirmed radiologically, and managed expectantly without } \\
\text { abdominal reoperation. }{ }^{83}\end{array}$ & $\begin{array}{l}C=N . A . \\
R=12.3(7.5-13.9)\end{array}$ \\
\hline
\end{tabular}

C=Colon, R=Rectum, N.A.=Not applicable. * \% leakage calculated with pooled means from all papers included in specific category. The range of the reported incidence of the different articles included in a specific category is given. 
Table 3.2 Symptoms associated with colorectal anastomotic leakage as reported in definition or means of diagnosis.

\begin{tabular}{lc}
\hline Symptom & Reported in papers: $\mathbf{n}(\%)$ \\
\hline Peritonitis & $115(48.3)$ \\
Discharge from drain & $115(48.3)$ \\
Fever & $97(40.8)$ \\
Discharge from rectum & $68(28.6)$ \\
Rectovaginal fistula & $68(28.6)$ \\
Abdominal pain & $66(27.7)$ \\
Dehiscence identified upon palpation & $59(24.8)$ \\
Leukocytosis & $55(23.1)$ \\
Sepsis & $43(18.1)$ \\
Tachycardia & $26(10.9)$ \\
Tachypnea & $19(8.0)$ \\
Discharge from wound & $18(7.6)$ \\
Increased C-reactive protein (CRP) & $14(5.9)$ \\
lleus & $13(5.5)$ \\
\hline
\end{tabular}

Table 3.3 Use of various grading systems for the severity of colorectal anastomotic leakage.

\begin{tabular}{|c|c|c|}
\hline Reference & Grading terms & Description \\
\hline $\begin{array}{l}\text { Midura et al. } 2015^{71} \\
\text { Snijders et al. } 2015^{84} \\
\text { Garcia et al. } 2013^{85}\end{array}$ & Minor / Mild & $\begin{array}{l}\text { Can be treated conservatively or by } \\
\text { radiologic intervention }\end{array}$ \\
\hline 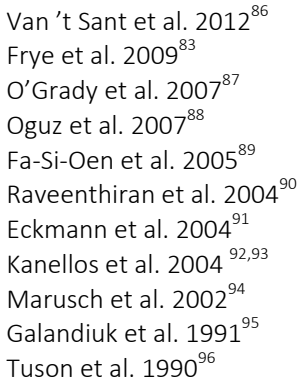 & Major / Severe & Requires surgical reintervention \\
\hline Vermeer et al. $2014^{22}$ & Presacral abscess & $\begin{array}{l}\text { Abscess on the anterior side of the of the } \\
\text { sacrum without extravasation of enteral } \\
\text { contrast on CT-scan or signs of generalized } \\
\text { peritonitis due to CAL }\end{array}$ \\
\hline \multirow{4}{*}{$\begin{array}{l}\text { Hua et al. } 2014^{97} \\
\text { Walker et al. } 2004^{98}\end{array}$} & Anastomotic leakage & $\begin{array}{l}\text { Extravasation of enteral contrast on CT- } \\
\text { scan, the presence of a PA in combination } \\
\text { with a defect in the anastomosis on } \\
\text { palpation or the presence of fecal } \\
\text { peritonitis when performing a laparotomy. }\end{array}$ \\
\hline & Minor / Local & $\begin{array}{l}\text { Can be treated conservatively or by } \\
\text { radiologic intervention }\end{array}$ \\
\hline & Major / General & Requires surgical reintervention \\
\hline & No clinical / Radiological & $\begin{array}{l}\text { Diagnosed radiologically, without clinical } \\
\text { symptoms }\end{array}$ \\
\hline
\end{tabular}


Table 3.3 (continued)

\begin{tabular}{|c|c|c|}
\hline Reference & Grading terms & Description \\
\hline \multirow[t]{3}{*}{ Ashraf et al. $2013^{99}$} & i peritoneal & $\begin{array}{l}\text { Requires laparotomy, washout and } \\
\text { formation of stoma }\end{array}$ \\
\hline & ii contained pelvic & $\begin{array}{l}\text { Managed with EUA with pelvic washout, } \\
\text { with or without VAC endosponge therapy }\end{array}$ \\
\hline & iii localized perianastomotic & $\begin{array}{l}\text { Managed conservatively by percutaneous } \\
\text { radiological drainage and/or antibiotics }\end{array}$ \\
\hline Shiomi et al. $2015^{18}$ & ISREC: Grade A & No change in patients' management \\
\hline
\end{tabular}

Yun et al. $2015^{19}$

Dauser et al. $2014^{20}$

Placer et al. $2014^{21}$

Reilly et al. $2014^{29}$

Kawada et al. $2014^{30}$

Krarup et al. $2014^{100}$

Vermeer et al. $2014^{22}$

Boesen et al. $2013^{23}$

Kulu et al. $2013^{24}$

Morks et al. $2013^{55}$

Nerup et al. $2013^{25}$

Saber et al. $2013^{28}$

Bakker et al. $2012^{26}$

Penninckx et al. $2012^{27}$

Garcia-Granero et al. $2013^{85}$ Minor

Grade B

Requires active therapeutic intervention but is manageable without re-laparotomy

Grade C

Requires re-laparotomy.

Asoglu et al. $2013^{34}$

Major

Symptomatic / Clinical

Mongin et al. $2014^{101}$

Ogilvie et al. $2012^{102}$

Piessen et al. $2012^{41}$

Fong et al. $2011^{103}$

Lim et al. $2006^{104}$

Millan et al. $2006^{105}$

Rudinskaite et al. $2005^{106}$

Bell et al. $2003^{10}$

Dehni et al. $1998^{107}$

Petersen et al. $1998^{108}$

Moore et al. $1996^{109}$

Bokey et al. $1995^{110}$

Bugiantella et al. $2014^{111}$

Leroy et al. $2004^{112}$

Brown et al. $2001^{113}$

Merad et al. $1998^{114}$

Akyol et al. $1992^{115}$ Occult
Conservative medical treatment, Clavien-

Dindo grades I and II

Need of reoperation or percutaneous radiological drainage, Clavien-Dindo grades III to $\mathrm{V}$

The presence of peritonitis, fever, or when gas, pus, or feces were discharged from the abdominal drain or from the vagina.

Asymptomatic / Radiological /

Considered if CAL was assessed on the systematic CT scan with contrast enema performed before diverting stoma reversal, without any relevant clinical symptom 
Table 3.3 (continued)

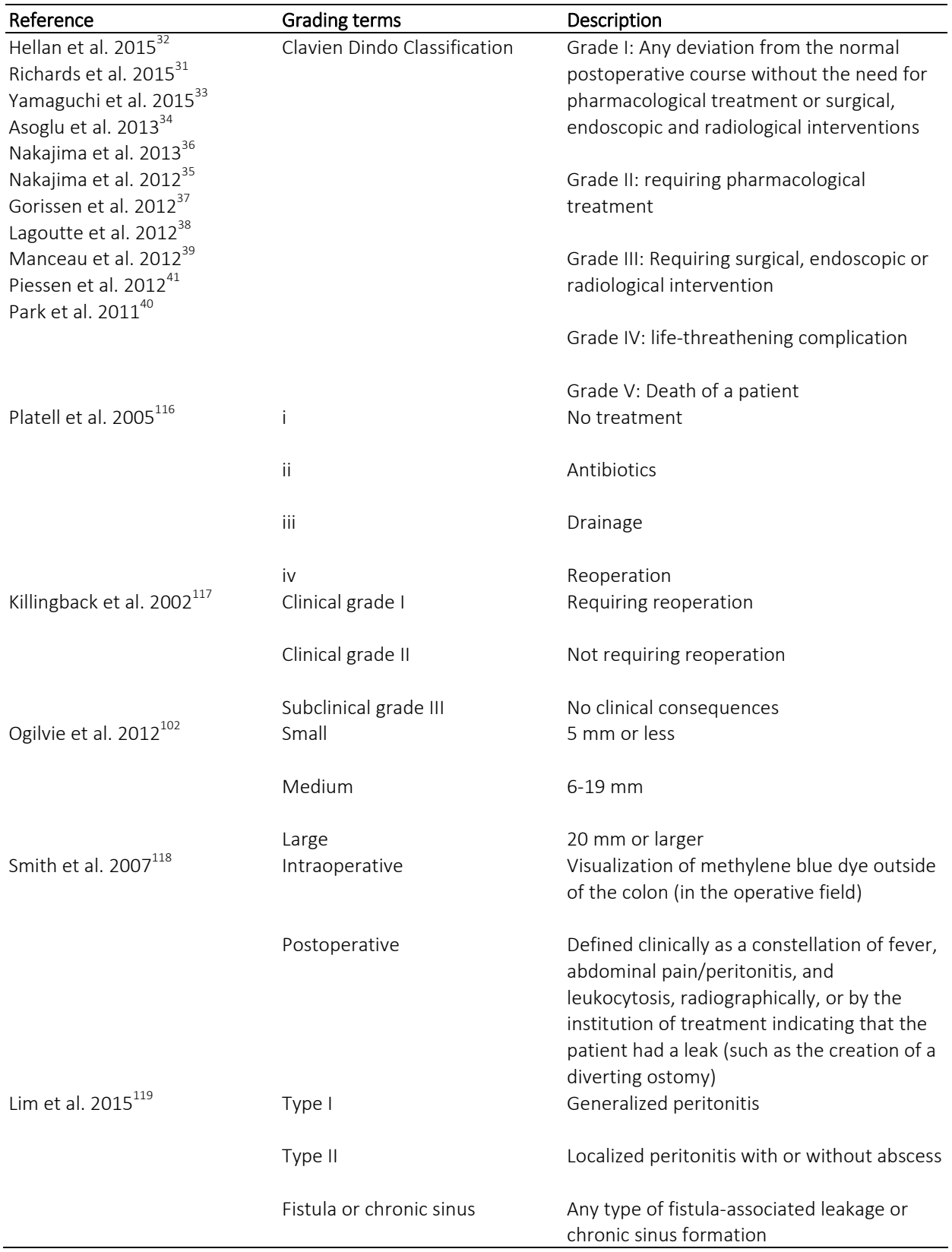


Table 3.3 (continued)

\begin{tabular}{lll}
\hline Reference & Grading terms & Description \\
\hline Caulfield et al. $2013^{120}$ & Gross & $\begin{array}{l}\text { defined as a disruption of the anastomosis } \\
\text { identified at reoperation or extravasation of } \\
\text { contrast medium at the anastomotic site on } \\
\text { an imaging study, irrespective of the } \\
\text { presence of symptoms. }\end{array}$ \\
& $\begin{array}{l}\text { An abscess or free pelvic fluid } \\
\text { Occult }\end{array}$ \\
& $\begin{array}{l}\text { collection without extravasation of contrast } \\
\text { medium was considered an occult }\end{array}$ \\
& \\
\hline
\end{tabular}

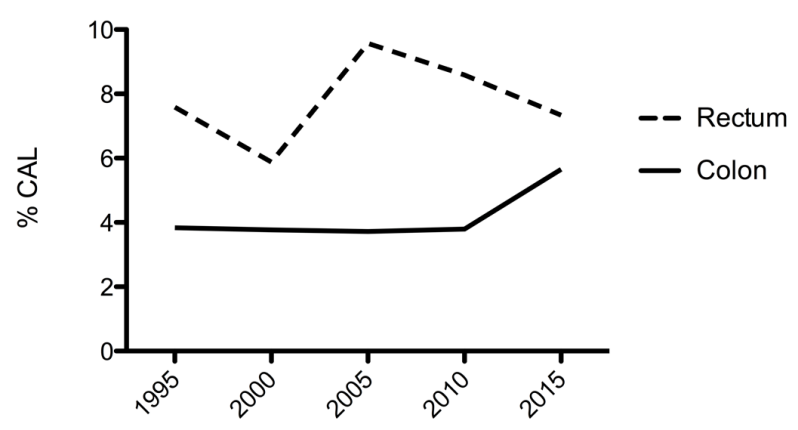

Figure 3.3 Reported mean incidence rates for colorectal anastomotic leakage for colon and rectal anastomoses over the past 25 years.

\section{Uniformity in data reporting}

Information that had been taken into account in this review also included specific information regarding the operative procedure and the period directly following surgery. The median time to diagnosis of CAL was only sparsely described in the investigated papers: a total of 56 papers (15.5\%) reported a mean or median interval to CAL diagnosis, ranging from 3.5 to 43 days. Furthermore, standard testing of the integrity of the primary anastomosis was underreported in most papers: only 71 authors (20\%) reported data on standard intraoperative testing with e.g. insufflated air or water, contrast enema, donut assessment, palpation of the anastomosis or flexible sigmoidoscopy. The information regarding the construction of a deviating ostomy was described much better in the included papers: a total of 241 papers (66.8\%) reported on the number of cases in which a deviating ostomy was created during the index surgery, 
however, hardly any papers reported whether these consisted of colostomies or ileostomies.

\section{Discussion}

The present literature review shows that there is no commonly used definition of both colon and rectal anastomotic leakage available. The numbers of papers published on this subject have increased tremendously over the past years. Surprisingly, our study showed that more than half of these papers do not report on what is considered CAL, despite the fact that CAL was their primary outcome measure. Another important finding of this study was the large variety of definitions used, which also impacted reported CAL rates between categorized definitions. This systematic review provides insight in the different components of definitions used that might serve as the basis of a future Delphi-based proposal for a novel definition that will be used by clinicians and researchers worldwide.

Several definitions of CAL have been proposed in the past, ranging from a theoretical to an extensive clinical description, and definitions including grading systems to differentiate between stages of clinical severity and their impact on treatment ${ }^{42,43}$. The Dutch Surgical Colorectal Audit, a registration database for colorectal surgery patients, described CAL as a leakage of bowel content or abscess formation near the anastomosis for which a relaparotomy and/or radiologic drainage was conducted ${ }^{44}$. Descriptions in all reviewed papers are in some way similar and mostly describe the general entity of CAL. However, as the clinical presentation of this specific complication can differ significantly with regards to severity, such a general definition of CAL is limited in its clinical usability and comparison of data.

The international study group of rectal cancer (ISREC) introduced a grading system in which the clinical impact of rectal anastomotic leakage is included ${ }^{42,45,46}$. Grade A severity indicates no change in patient management, whereas grade $B$ requires active therapeutic interventions but is manageable without relaparotomy. Grade C leakage has the largest clinical impact and requires relaparotomy. The most commonly used other grading systems in this systematic review based their severity grading either on clinical presentation, means of diagnosis or the resulting management of the complication. Grading the severity of CAL is of importance as it may give an indication of the required intervention, prognosis and consequences for the individual patient. A confined anastomotic leak with mild clinical symptoms may be treated conservatively or with oral antibiotics alone, while an abscess surrounding the anastomosis may be drained 
radiologically. Although the ISREC definition and grading system is rather complete and has been used by a number of authors, it has not yet been fully implemented in daily clinical practice and research. Some authors believe that by the use of this definition, no distinction can be made between anastomotic leakage and a presacral abscess, which is not necessarily an indication for a leak, as it could be formed due to peroperative spill or an infected hematoma ${ }^{22,47}$. The fact that others did indeed classify presacral abscess formation as indicative for a leak ${ }^{48,49}$, clearly shows that several issues need to be resolved in order to come to complete agreement regarding a new definition for CAL.

With the formation of this new definition, we may even discuss whether CAL is the right description and if it were not more appropriate to focus on the period of intestinal healing directly following surgery instead. An impaired healing process may result in clinical consequences such as a prolonged hospital stay, administration of antibiotics, radiological drainage of an abscess, a reoperation including a prolonged hospital stay or even intensive care stay, and in worst case scenario long lasting sepsis with substantial additional consequences for the patient (e.g. significant duration of hospitalization, delayed return to functional capacity and work or additional treatment [chemotherapy/surgery for metastasis], and/or decreased health related quality of life), or even death. We may consider identifying and modifying all risk factors that are potentially related to the healing process. These modifiable risk factors may be patient related and present preoperatively ${ }^{50}$, or may be part of the intraoperative approach such as vascularization, technique of anastomosis construction, blood loss and use of inotropes ${ }^{51-53}$. We may consider impaired healing as part of a future definition but should also include the effects that these outcomes have on our patients. From the patient's point of view, prolonged hospital stay or even a re-intervention could be seen as being more important than the burden of living with a temporary or permanent stoma. For another patient, however, the impact on quality of life that a stoma has may not outweigh the risk of developing CAL and its associated clinical consequences. We would therefore advise to include information regarding the presence and type of a deviating ostomy in future reports on CAL.

Before we are able to formulate a definition for colorectal anastomotic leakage that will be accepted by both clinicians and research groups worldwide, several issues need to be addressed. First, the terminology of a leak varies widely as shown in this review (See Table 3.1), which makes interpretation of study outcomes rather difficult. Secondly, timing of CAL occurrence has also been described as part of the definition. This present study shows that there is a wide range within the postoperative course to diagnose CAL. It is unclear whether the duration of follow-up taken into account in the different papers 
has had a significant influence on this range, as a considerable number of CAL cases are diagnosed after the direct postoperative period of 30 days ${ }^{54,55}$. In fact, when also taking into account cases of CAL that are diagnosed after discharge and/or more than 30 days after low anterior resection, incidence rates show an up to $40 \%$ increase i, $^{54,55}$. Interestingly, some studies found that the construction of a deviating ostomy reduced the numbers of early anastomotic leak. This was, however, not the case for the late anastomotic leaks suggesting that in the presence of a temporary ostomy CAL diagnosis is delayed ${ }^{56,54}$. Some authors may consider early and late anastomotic leakage as separate entities, and may therefore underreport late anastomotic leaks as such ${ }^{57}$. It was indeed shown that the clinical course differs considerably between early and late CAL. with early CAL requiring more often a relaparotomy and the construction of a permanent ileostomy. Finally, preoperative radiotherapy increases the risk of late, but not early $\mathrm{CAL}^{55,58,57}$.

Furthermore, colon and rectal anastomotic leakage may be seen and described as separate entities. Reasons to consider rectal and colonic anastomotic leakage as two separate problems include the different reported incidence rates, which were again confirmed by the results of this review, the different anatomy, surgical techniques and microbial composition ${ }^{59}$. However, the studies included in this review that reported separate incidence rates for rectal and colon anastomoses did not specify what was considered rectum and colon. This is interesting, as specialists involved in the care of the colorectal patient such as radiologists, surgeons and pathologists, define the rectosigmoid junction differently. In radiology, the rectosigmoid junction is somewhat arbitrarily defined as $15 \mathrm{~cm}$ above the anal verge, or, in some cases, $15 \mathrm{~cm}$ above the dentate line. As surgeons and pathologist can directly view the anatomical landmarks, the rectosigmoid junction is determined differently: where the teniae coli coalesce to form a continuous outer longitudinal muscle layer ${ }^{60}$. In contrast to rectal anastomotic leakage, an exact definition of colonic anastomotic leakage is only sporadically found in literature ${ }^{45,61}$. It is highly recommended that these aforementioned issues are resolved in collaboration with an expert panel prior to the construction of a novel definition.

Several important other factors should be taken into account when comparing results from different studies, such as methodology, duration of follow-up and method of collection and reporting of data. Uniform reporting of data has gained attention over the past years, with the CONSORT Statement for RCT's being one of the first to provide guidance about what should be reported in a research article ${ }^{62}$. Several other guidelines have been developed since, a trend that is welcomed and supported by a number of organizations such as the Council of Science Editors and the International Committee of Medical Journal Editors ${ }^{63,64}$. Based on the findings (and the lack thereof) regarding the 
reporting of data in this extensive literature review, the authors believe the research field of colorectal anastomotic leakage would greatly benefit from increased guidance on the reporting of data. We strongly feel that both uniformity in the use of a CAL definition as well as equality in the reported information would positively influence comparability of study data and would allow for the reliable interpretation of meta-analyses. In collaboration with an expert working group, the Dutch Taskforce for Anastomotic Leakage, a set of guidelines has been drafted to address this issue. The authors therefore recommend that newly published papers in this field adhere to the standard reporting of the following 11 points: type of surgery and height of anastomosis, standard testing of integrity of anastomosis both during and after surgery (prior to temporary stoma reversal), construction of deviating ostomies and type of ostomy (primary and secondary), median interval of CAL diagnosis from day of surgery, diagnostic tools used to establish diagnosis of CAL, clinical symptoms associated with the diagnosis of CAL, separate leakage numbers for colon and rectal anastomoses, the use of a grading system and associated treatment plan. A checklist describing these 11 points in more detail can be found in the Supplementary Table S3.2.

The need for an all-embracing definition of colorectal anastomotic leakage continues to exist, so that comparability of study results and understanding between all members of the medical team increases. The authors strongly believe that implementation of a graded system with treatment recommendations for the different severity grades will enhance uniformity of patient care and may lead to decreased delay in treatment ${ }^{65,66}$. The results of this paper and those of a consensus assessment among surgeons in the Netherlands and China ${ }^{17}$ will be used to initiate a Delphi round, that will eventually lead to the formulation of a uniform definition of CAL supported by a large panel of experts. 


\section{References}

1. Bakker IS, Grossmann I, Henneman D, et al. Risk factors for anastomotic leakage and leak-related mortality after colonic cancer surgery in a nationwide audit. Br J Surg 2014;101(4):424-32; discussion 32.

2. McDermott FD, Heeney A, Kelly ME, et al. Systematic review of preoperative, intraoperative and postoperative risk factors for colorectal anastomotic leaks. Br J Surg 2015;102(5):462-79.

3. Kirchhoff P, Clavien PA, Hahnloser D. Complications in colorectal surgery: risk factors and preventive strategies. Patient Saf Surg 2010;4(1):5.

4. Bertelsen $\mathrm{CA}$, Andreasen $\mathrm{AH}$, Jorgensen $\mathrm{T}$, et al. Anastomotic leakage after curative anterior resection for rectal cancer: short and long-term outcome. Colorectal Dis 2010;12(7 Online):e76-81.

5. McArdle CS, McMillan DC, Hole DJ. Impact of anastomotic leakage on long-term survival of patients undergoing curative resection for colorectal cancer. Br J Surg 2005;92(9):1150-4.

6. Govaert JA, Fiocco M, van Dijk WA, et al. Costs of complications after colorectal cancer surgery in the Netherlands: Building the business case for hospitals. Eur J Surg oncol 2015;41(8):1059-67.

7. Hammond J, Lim S, Wan Y, et al. The burden of gastrointestinal anastomotic leaks: an evaluation of clinical and economic outcomes. J Gastrointest Surg 2014;18(6):1176-85.

8. Koperna T. Cost-effectiveness of defunctioning stomas in low anterior resections for rectal cancer: a call for benchmarking. Arch Surg 2003;138(12):1334-8; discussion 9.

9. Kulu Y, Tarantio I, Warschkow R, et al. Anastomotic leakage is associated with impaired overall and disease-free survival after curative rectal cancer resection: a propensity score analysis. Ann Surg Oncol 2015;22(6):2059-67.

10. Bell SW, Walker KG, Rickard MJ, et al. Anastomotic leakage after curative anterior resection results in a higher prevalence of local recurrence. Br J Surg 2003;90(10):1261-6.

11. Adams K, Papagrigoriadis S. Little consensus in either definition or diagnosis of a lower gastro-intestinal anastomotic leak amongst colorectal surgeons. Int J Colorectal Dis 2013;28(7):967-71.

12. Rondelli F, Balzarotti R, Bugiantella W, et al. Temporary percutaneous ileostomy versus conventional loop ileostomy in mechanical extraperitoneal colorectal anastomosis: a retrospective study. Eur J Surg Oncol 2012;38(11):1065-70.

13. Biondo S, Kreisler E, Millan M, et al. Impact of surgical specialization on emergency colorectal surgery outcomes. Arch Surg 2010;145(1):79-86.

14. Singh PP, Zeng IS, Srinivasa S, et al. Systematic review and meta-analysis of use of serum C-reactive protein levels to predict anastomotic leak after colorectal surgery. Br J Surg 2014;101(4):339-46.

15. Reinke CE, Showalter S, Mahmoud NN, et al. Comparison of anastomotic leak rate after colorectal surgery using different databases. Dis Colon Rectum 2013;56(5):638-44.

16. Bruce J, H ZHKZ, Al-Khairy G, et al. Systematic review of the definition and measurement of anastomotic leak after gastrointestinal surgery. Br J Surg 2001;88(9):1157-68.

17. van Rooijen SJ, Jongen ACHM, Wu ZQ, et al. Definition of colorectal anastomotic leakage: A consensus survey among Dutch and Chinese colorectal surgeons. World J Gastroenterol 2017;23(33):6172-80.

18. Shiomi A, Ito M, Maeda K, et al. Effects of a diverting stoma on symptomatic anastomotic leakage after low anterior resection for rectal cancer: a propensity score matching analysis of 1,014 consecutive patients. J Am Coll Surg 2015;220(2):186-94.

19. Yun JA, Cho YB, Park YA, et al. Clinical manifestations and risk factors of anastomotic leakage after low anterior resection for rectal cancer. ANZ J Surg 2017;87(11):908-914

20. Dauser B, Herbst F. Diagnosis, management and outcome of early anastomotic leakage following colorectal anastomosis using a compression device: is it different? Colorectal Dis 2014;16(12):0435-9.

21. Placer C, Enriquez-Navascues JM, Elorza G, et al. Preventing complications in colorectal anastomosis: results of a randomized controlled trial using bioabsorbable staple line reinforcement for circular stapler. Dis Colon Rectum 2014;57(10):1195-201.

22. Vermeer TA, Orsini RG, Daams F, et al. Anastomotic leakage and presacral abscess formation after locally advanced rectal cancer surgery: Incidence, risk factors and treatment. Eur J Surg Oncol 2014;40(11): 1502-9. 
23. Boesen AK, Maeda Y, Rorbaek Madsen M. Perioperative fluid infusion and its influence on anastomotic leakage after rectal cancer surgery: implications for prevention strategies. Colorectal Dis 2013;15(9):e522-7.

24. ulu Y, Ulrich A, Bruckner T, et al. Validation of the International Study Group of Rectal Cancer definition and severity grading of anastomotic leakage. Surgery 2013;153(6):753-61.

25. Nerup N, Johansen JL, Alkhefagie GA, et al. Promising results after endoscopic vacuum treatment of anastomotic leakage following resection of rectal cancer with ileostomy. Dan Med J 2013;60(4):A4604.

26. Bakker IS, Morks AN, Hoedemaker HO, et al. The C-seal trial: colorectal anastomosis protected by a biodegradable drain fixed to the anastomosis by a circular stapler, a multi-center randomized controlled trial. BMC Surg 2012;12:23.

27. Penninckx F, Beirens K, Fieuws S, et al. Risk adjusted benchmarking of clinical anastomotic leakage rate after total mesorectal excision in the context of an improvement project. Colorectal Dis 2012;14(7):e413-21.

28. Saber A, Hokkam EN. Efficacy of protective tube cecostomy after restorative resection for colorectal cancer: a randomized trial. Int J Surg 2013;11(4):350-3.

29. Reilly F, Burke JP, Appelmans E, et al. Incidence, risks and outcome of radiological leak following early contrast enema after anterior resection. Int J Colorectal Dis 2014;29(4):453-8.

30. Kawada K, Hasegawa S, Hida K, et al. Risk factors for anastomotic leakage after laparoscopic low anterior resection with DST anastomosis. Surg Endosc 2014;28(10):2988-95.

31. Richards $\mathrm{CH}$, Roxburgh CS. Surgical outcome in patients undergoing reversal of Hartmann's procedures: a multicentre study. Colorectal Dis 2015;17(3):242-9.

32. Hellan M, Ouellette J, Lagares-Garcia JA, et al. Robotic Rectal Cancer Resection: A Retrospective Multicenter Analysis. Ann Surg Oncol 2015;22(7):2151-8.

33. Yamaguchi $T$, Kinugasa $Y$, Shiomi A, et al. Robotic-assisted laparoscopic versus open lateral lymph node dissection for advanced lower rectal cancer. Surg Endosc 2016;30(2):721-8

34. Asoglu O, Balik E, Kunduz E, et al. Laparoscopic surgery for rectal cancer: outcomes in 513 patients. World J Surg 2013;37(4):883-92.

35. Nakajima K, Takahashi S, Saito N, et al. Predictive factors for anastomotic leakage after simultaneous resection of synchronous colorectal liver metastasis. J Gastrointest Surg 2012;16(4):821-7.

36. Nakajima K, Takahashi S, Saito N, et al. Efficacy of the predicted operation time (POT) strategy for synchronous colorectal liver metastasis (SCLM): feasibility study for staged resection in patients with a long POT. J Gastrointest Surg 2013;17(4):688-95.

37. Gorissen KJ, Benning D, Berghmans T, et al. Risk of anastomotic leakage with non-steroidal antiinflammatory drugs in colorectal surgery. Br J Surg 2012;99(5):721-7.

38. Lagoutte N, Facy O, Ravoire A, et al. C-reactive protein and procalcitonin for the early detection of anastomotic leakage after elective colorectal surgery: pilot study in 100 patients. J Visc Surg 2012;149(5):e345-9.

39. Manceau G, Karoui M, Breton S, et al. Right colon to rectal anastomosis (Deloyers procedure) as a salvage technique for low colorectal or coloanal anastomosis: postoperative and long-term outcomes. Dis Colon Rectum 2012;55(3):363-8.

40. Park JS, Choi GS, Lim KH, et al. S052: a comparison of robot-assisted, laparoscopic, and open surgery in the treatment of rectal cancer. Surg Endosc 2011;25(1):240-8.

41. Piessen G, Cabral C, Benoist S, et al. Previous transanal full-thickness excision increases the morbidity of radical resection for rectal cancer. Colorectal Dis 2012;14(4):445-52.

42. Rahbari NN, Weitz J, Hohenberger W, et al. Definition and grading of anastomotic leakage following anterior resection of the rectum: a proposal by the International Study Group of Rectal Cancer. Surgery 2010;147(3):339-51.

43. Peel AL, Taylor EW. Proposed definitions for the audit of postoperative infection: a discussion paper. Surgical Infection Study Group. Ann R Coll Surg Engl 1991;73(6):385-8.

44. Snijders HS, van den Broek CB, Wouters MW, et al. An increasing use of defunctioning stomas after low anterior resection for rectal cancer. Is this the way to go? Eur J Surg Oncol 2013;39(7):715-20.

45. Kulu Y, Ulrich A, Bruckner T, et al. Validation of the International Study Group of Rectal Cancer definition and severity grading of anastomotic leakage. Surgery 2013;153(6):753-61. 
46. Matsuda K, Hotta T, Takifuji K et al. Clinical characteristics of anastomotic leakage after an anterior resection for rectal cancer by assessing of the international classification on anastomotic leakage. Langenbecks Arch Surgery 2015;400(2):207-12.

47. Bucher P, Gervaz P, Soravia C, et al. Randomized clinical trial of mechanical bowel preparation versus no preparation before elective left-sided colorectal surgery. Br J Surg 2005;92(4):409-14.

48. Korkolis DP, Plataniotis GD, Gondikakis E, et al. Short-term preoperative radiotherapy is a safe approach for treatment of locally advanced rectal cancer. Int J Colorectal Dis 2006;21(1):1-6.

49. Peeters KC, Tollenaar RA, Marijnen CA et al. Risk factors for anastomotic failure after total mesorectal excision of rectal cancer. Br J Surg 2005;92(2):211-6.

50. van Rooijen S, Carli F, Dalton SO et al. Preoperative modifiable risk factors in colorectal surgery: an observational cohort study identifying the possible value of prehabilitation. Acta Oncol 2017;56(2): 329-34.

51. van Rooijen SJ, Huisman D, Stuijvenberg M, et al. Intraoperative modifiable risk factors of colorectal anastomotic leakage: Why surgeons and an,esthesiologists should act together. Int J Surg 2016;36(Pt A):183-200.

52. Kudszus S, Roesel C, Schachtrupp A, et al. Intraoperative laser fluorescence angiography in colorectal surgery: a noninvasive analysis to reduce the rate of anastomotic leakage. Langenbecks Arch Surg 2010;395(8):1025-30.

53. Hemming K, Pinkney T, Futaba K, et al. A systematic review of systematic reviews and panoramic metaanalysis: staples versus sutures for surgical procedures. PloS One 2013;8(10):e75132.

54. Borstlap WAA, Westerduin E, Aukema TS et al. Anastomotic Leakage and Chronic Presacral Sinus Formation After Low Anterior Resection: Results From a Large Cross-sectional Study. Ann Surg 2017;266(5):870-7.

55. Morks AN, Ploeg RJ, Sijbrand Hofker H, et al. Late anastomotic leakage in colorectal surgery: a significant problem. Colorectal Dis 2013;15(5):e271-5.

56. Lim SB, Yu CS, Kim CW, et al. Late anastomotic leakage after low anterior resection in rectal cancer patients: clinical characteristics and predisposing factors. Colorectal Dis 2016;18(4):0135-40.

57. Floodeen $\mathrm{H}$, Hallbook $\mathrm{O}$, Rutegard J, et al. Early and late symptomatic anastomotic leakage following low anterior resection of the rectum for cancer: are they different entities? Colorectal Dis 2013;15(3): 334-40. 5

58. Matthiessen P, Lindgren R, Hallbook O, et al. Symptomatic anastomotic leakage diagnosed after hospital discharge following low anterior resection for rectal cancer. Colorectal Dis 2010;12(7 Online):e82-7.

59. Donaldson GP, Lee SM, Mazmanian SK. Gut biogeography of the bacterial microbiota. Nat Rev Microbiol 2016;14(1):20-32.

60. Lowry AC, Simmang CL, Boulos $\mathrm{P}$, et al. Consensus statement of definitions for anorectal physiology and rectal cancer. ANZ J Surg 2001;71(10):603-5.

61. Welsch T, von Frankenberg M, Schmidt J, et al. [Diagnosis and definition of anastomotic leakage from the surgeon's perspective]. Der Chirurg; Zeitschrift fur alle Gebiete der operativen Medizen 2011;82(1): 48-55.

62. Schulz KF, Altman DG, Moher D, et al. CONSORT 2010 statement: updated guidelines for reporting parallel group randomised trials. BMJ 2010;340:c332.

63. Scott-Lichter D and the Editorial Policy Committee COSE. CSE's White Paper on Promoting Integrity in Scientific Journal Publications. Wheat Ridge, CO2012.

64. Editors ICOMJ. Recommendations for the Conduct, Reporting, Editing and Publication of Scholarly Work in Medical Journals. http://www.ICMJE.org. Accessed 10/01/2017 2017.

65. Damrauer SM, Bordeianou L, Berger D. Contained anastomotic leaks after colorectal surgery: are we too slow to act? Arch Surg 2009;144(4):333-8; discussion 8.

66. Macarthur DC, Nixon SJ, Aitken RJ. Avoidable deaths still occur after large bowel surgery. Scottish Audit of Surgical Mortality, Royal College of Surgeons of Edinburgh. Br J Surg 1998;85(1):80-3. 


\section{Supplementary Data}

Table S3.1 Items suggested by the Taskforce Colorectal Anastomotic Leakage to be considered in standard reporting.

\begin{tabular}{|c|c|}
\hline Item & Report \\
\hline \multicolumn{2}{|l|}{ Construction of anastomosis } \\
\hline Type of surgery & Colon/rectum \\
\hline Height of anastomosis & In $\mathrm{cm}$ from the anal verge \\
\hline \multirow[t]{2}{*}{ Stoma construction } & Primary/secondary \\
\hline & $\begin{array}{l}\text { Deviating ileostomy/deviating colostomy/end } \\
\text { ileostomy/end colostomy }\end{array}$ \\
\hline Test of integrity during surgery & Air leak test/... \\
\hline \multicolumn{2}{|l|}{ Clinical symptoms } \\
\hline DULK score & Yes/no, if yes score: ... \\
\hline Leukocytosis & $>10 \times 10^{9} / /$ \\
\hline Sepsis & Yes/no \\
\hline Tachycardia & $>100 /$ minute \\
\hline Tachypnea & $>20 /$ minute \\
\hline Increased C-reactive protein & $>250$ \\
\hline Discharge from wound & Yes/no \\
\hline Abdominal pain (other than wound pain) & Yes/no \\
\hline Fever & $>38$ degrees Celsius \\
\hline Discharge from drain & Yes/no \\
\hline Discharge from rectum & Yes/no \\
\hline Rectovaginal fistula & Yes/no \\
\hline Ileus & No stool $>4$ days postoperatively \\
\hline \multicolumn{2}{|l|}{ Diagnosis } \\
\hline Moment of diagnosis & Median interval in days from surgery \\
\hline Diagnostic tools & $\mathrm{CT} / \mathrm{X}$-thorax/laboratory/... \\
\hline Dehiscence identified upon palpation & Yes/no \\
\hline Radiological diagnosis & $\begin{array}{l}\text { No leakage, infiltration anastomosis, abscess around } \\
\text { anastomosis, free abdominal air, free fluids abdomen }\end{array}$ \\
\hline \multicolumn{2}{|l|}{ Outcome } \\
\hline Hospital stay & Number of days until discharge \\
\hline Prolonged hospital stay & $>5$ days \\
\hline Intensive care stay & Yes/no \\
\hline Treatment & $\begin{array}{l}\text { Conservative, ileus treatment, antibiotics, percutaneous } \\
\text { drainage, reoperation with extra suture and deviating } \\
\text { stoma, reoperation with reconstruction new anastomosis } \\
\text { and deviating stoma, reoperation with end stoma } \\
\text { Yes/no }\end{array}$ \\
\hline Delayed functional recovery & Yes/no \\
\hline $\begin{array}{l}\text { Delayed start of additional therapy (chemo/surgery } \\
\text { for metastasis) } \\
\text { Delayed return to work }\end{array}$ & Yes/no \\
\hline
\end{tabular}


Table S3.2 List of included articles in systematic review

\begin{tabular}{|c|c|c|}
\hline Author & Year & Title \\
\hline Zerhouni & 2015 & $\begin{array}{l}\text { Severity of inflammation as a risk factor for ileo-anal anastomotic leak after a pouch } \\
\text { procedure in ulcerative colitis }\end{array}$ \\
\hline Yun & 2015 & $\begin{array}{l}\text { Clinical manifestations and risk factors of anastomotic leakage after low anterior } \\
\text { resection for rectal cancer }\end{array}$ \\
\hline Yamaguchi & 2015 & $\begin{array}{l}\text { Robotic-assisted laparoscopic versus open lateral lymph node dissection for advanced } \\
\text { lower rectal cancer }\end{array}$ \\
\hline Vestweber & 2015 & $\begin{array}{l}\text { Single-port laparoscopic resection for diverticular disease: experiences with more than } \\
300 \text { consecutive patient }\end{array}$ \\
\hline Turrentine & 2015 & Morbidity, mortality, cost, and survival estimates of gastrointestinal anastomotic leaks \\
\hline Torba & 2015 & $\begin{array}{l}\text { The influence of the risk factor on the abdominal complications in colon injury } \\
\text { management }\end{array}$ \\
\hline Tanaka & 2015 & Analysis of anastomotic leakage after rectal surgery: A case-control study \\
\hline Snijders & 2015 & Optimal treatment strategy in rectal cancer surgery: should we be cowboys or chickens \\
\hline Shiomi & 2015 & $\begin{array}{l}\text { Effects of a Diverting Stoma on Symptomatic Anastomotic Leakage after Low Anterior } \\
\text { Resection for Rectal Cancer: A Propensity Score Matching Analysis of 1,014 Consecutive } \\
\text { Patients }\end{array}$ \\
\hline Scarborough & 2015 & $\begin{array}{l}\text { Combined Mechanical and Oral Antibiotic Bowel Preparation Reduces Incisional Surgical } \\
\text { Site Infection and Anastomotic Leak Rates After Elective Colorectal Resection: An } \\
\text { Analysis of Colectomy-Targeted ACS NSQIP }\end{array}$ \\
\hline Richards & 2015 & $\begin{array}{l}\text { Surgical outcome in patients undergoing reversal of Hartmann's procedures: a } \\
\text { multicentre study }\end{array}$ \\
\hline Ramanathan & 2015 & $\begin{array}{l}\text { The Impact of Open Versus Laparoscopic Resection for Colon Cancer on C-Reactive } \\
\text { Protein Concentrations as a Predictor of Postoperative Infective Complications }\end{array}$ \\
\hline Pittet & 2015 & $\begin{array}{l}\text { Rectal enema is an alternative to full mechanical bowel preparation for primary rectal } \\
\text { cancer surgery }\end{array}$ \\
\hline Midura & 2015 & Risk factors and consequences of anastomotic leak after colectomy: a national analysis \\
\hline Strangio & 2015 & $\begin{array}{l}\text { Endo-sponge therapy for management of anastomotic leakages after colorectal surgery: } \\
\text { A case series and review of literature }\end{array}$ \\
\hline Reisinger & 2015 & $\begin{array}{l}\text { Functional compromise reflected by sarcopenia, frailty, and nutritional depletion } \\
\text { predicts adverse postoperative outcome after colorectal cancer surgery }\end{array}$ \\
\hline Paulasir & 2015 & $\begin{array}{l}\text { Nonsteroidal Anti-inflammatory Drugs: Do They Increase the Risk of Anastomotic Leaks } \\
\text { Following Colorectal Operations? }\end{array}$ \\
\hline Matsuda & 2015 & $\begin{array}{l}\text { Transanal drainage tube placement to prevent anastomotic leakage following colorectal } \\
\text { cancer surgery with double stapling reconstruction }\end{array}$ \\
\hline Martin & 2015 & $\begin{array}{l}\text { Validation of a score for the early diagnosis of anastomotic leakage following elective } \\
\text { colorectal surgery }\end{array}$ \\
\hline Maeda & 2015 & Rarity of late anastomotic leakage after low anterior resection of the rectum \\
\hline $\operatorname{Lim}$ & 2015 & $\begin{array}{l}\text { The types of anastomotic leakage that develop following anterior resection for rectal } \\
\text { cancer demonstrate distinct characteristics and oncologic outcomes }\end{array}$ \\
\hline Krarup & 2015 & $\begin{array}{l}\text { Association of Comorbidity with Anastomotic Leak, 30-day Mortality, and Length of Stay } \\
\text { in Elective Surgery for Colonic Cancer: A Nationwide Cohort Study }\end{array}$ \\
\hline Komatsu & 2015 & $\begin{array}{l}\text { Efficacy of perioperative synbiotics treatment for the prevention of surgical site } \\
\text { infection after laparoscopic colorectal surgery: a randomized controlled trial }\end{array}$ \\
\hline Kiran & 2015 & $\begin{array}{l}\text { Combined Preoperative Mechanical Bowel Preparation With Oral Antibiotics } \\
\text { Significantly Reduces Surgical Site Infection, Anastomotic Leak, and Ileus After } \\
\text { Colorectal Surgery }\end{array}$ \\
\hline Kin & 2015 & $\begin{array}{l}\text { Equivocal effect of intraoperative fluorescence angiography on colorectal anastomotic } \\
\text { leaks }\end{array}$ \\
\hline
\end{tabular}


Table S3.2 (continued)

\begin{tabular}{|c|c|c|}
\hline Author & Year & Title \\
\hline Kim & 2015 & $\begin{array}{l}\text { Anastomotic Leakage After Low Anterior Resection for Rectal Cancer Is Different } \\
\text { Between Minimally Invasive Surgery and Open Surgery }\end{array}$ \\
\hline Kauv & 2015 & Anastomotic leakage after colorectal surgery: diagnostic accuracy of CT \\
\hline Kanso & 2015 & $\begin{array}{l}\text { Perineal or Abdominal Approach First During Intersphincteric Resection for Low Rectal } \\
\text { Cancer: Which Is the Best Strategy? }\end{array}$ \\
\hline $\mathrm{Hu}$ & 2015 & $\begin{array}{l}\text { A Clinical Parameters-Based Model Predicts Anastomotic Leakage After a Laparoscopic } \\
\text { Total Mesorectal Excision: A Large Study With Data From China }\end{array}$ \\
\hline Hellan & 2015 & Robotic Rectal Cancer Resection: A Retrospective Multicenter Analysis \\
\hline Hayden & 2015 & $\begin{array}{l}\text { Patient factors may predict anastomotic complications after rectal cancer surgery: } \\
\text { Anastomotic complications in rectal cancer }\end{array}$ \\
\hline Gustafsson & 2015 & $\begin{array}{l}\text { Higher frequency of anastomotic leakage with stapled compared to hand-sewn ileocolic } \\
\text { anastomosis in a large population-based study }\end{array}$ \\
\hline Frasson & 2015 & $\begin{array}{l}\text { Risk Factors for Anastomotic Leak After Colon Resection for Cancer: Multivariate } \\
\text { Analysis and Nomogram From a Multicentric, Prospective, National Study With } 3193 \\
\text { Patients }\end{array}$ \\
\hline Espin & 2015 & Oncological outcome following anastomotic leak in rectal surgery \\
\hline Ebinger & 2015 & $\begin{array}{l}\text { Anastomotic leakage after curative rectal cancer resection has no impact on long-term } \\
\text { survival: a propensity score analysis }\end{array}$ \\
\hline d'Hoore & 2015 & $\begin{array}{l}\text { COMPRES: a prospective postmarketing evaluation of the compression anastomosis ring } \\
\text { CAR 27/ColonRing }\end{array}$ \\
\hline Cho & 2015 & $\begin{array}{l}\text { Morphologic change of rectosigmoid colon using belly board and distended bladder } \\
\text { protocol }\end{array}$ \\
\hline Buscail & 2015 & $\begin{array}{l}\text { Surgery for rectal cancer after high-dose radiotherapy for prostate cancer: is sphincter } \\
\text { preservation relevant? }\end{array}$ \\
\hline Bostrom & 2015 & $\begin{array}{l}\text { High arterial ligation and risk of anastomotic leakage in anterior resection for rectal } \\
\text { cancer in patients with increased cardiovascular risk }\end{array}$ \\
\hline Baucom & 2015 & Smoking as dominant risk factor for anastomotic leak after left colon resection \\
\hline Alonso & 2015 & $\begin{array}{l}\text { Postoperative intra-abdominal infection and colorectal cancer recurrence: a prospective } \\
\text { matched cohort study of inflammatory and angiogenic responses as mechanisms } \\
\text { involved in this association }\end{array}$ \\
\hline Allaix & 2015 & Laparoscopic colon resection: To prep or not to prep? Analysis of 1535 patients \\
\hline Akladios & 2015 & $\begin{array}{l}\text { Is ileostomy always necessary following rectal resection for deep infiltrating } \\
\text { endometriosis? }\end{array}$ \\
\hline Ye & 2014 & Use of Valtrac-secured intracolonic bypass in laparoscopic rectal cancer resection \\
\hline Vermeer & 2014 & $\begin{array}{l}\text { Anastomotic leakage and presacral abscess formation after locally advanced rectal } \\
\text { cancer surgery: Incidence, risk factors and treatment }\end{array}$ \\
\hline Stey & 2014 & Outcomes and cost of diverted versus undiverted restorative proctocolectomy \\
\hline Snijders & 2014 & High 1-year complication rate after anterior resection for rectal cancer \\
\hline Senagore & 2014 & $\begin{array}{l}\text { Bioabsorbable staple line reinforcement in restorative proctectomy and anterior } \\
\text { resection: a randomized study }\end{array}$ \\
\hline Salvans & 2014 & $\begin{array}{l}\text { Postoperative peritoneal infection enhances migration and invasion capacities of tumor } \\
\text { cells in vitro: an insight into the association between anastomotic leak and recurrence } \\
\text { after surgery for colorectal cancer }\end{array}$ \\
\hline Reisinger & 2014 & $\begin{array}{l}\text { Accurate prediction of anastomotic leakage after colorectal surgery using plasma } \\
\text { markers for intestinal damage and inflammation }\end{array}$ \\
\hline Reilly & 2014 & $\begin{array}{l}\text { Incidence, risks and outcome of radiological leak following early contrast enema after } \\
\text { anterior resection }\end{array}$ \\
\hline Placer & 2014 & $\begin{array}{l}\text { Preventing complications in colorectal anastomosis: results of a randomized controlled } \\
\text { trial using bioabsorbable staple line reinforcement for circular stapler }\end{array}$ \\
\hline
\end{tabular}


Table S3.2 (continued)

\begin{tabular}{|c|c|c|}
\hline Author & Year & Title \\
\hline Nishigori & 2014 & $\begin{array}{l}\text { Effectiveness of a transanal tube for the prevention of anastomotic leakage after rectal } \\
\text { cancer surgery }\end{array}$ \\
\hline Nason & 2014 & $\begin{array}{l}\text { Early rise in C-reactive protein is a marker for infective complications in laparoscopic } \\
\text { colorectal surgery }\end{array}$ \\
\hline Mongin & 2014 & $\begin{array}{l}\text { Does anastomotic leakage impair functional results and quality of life after laparoscopic } \\
\text { sphincter-saving total mesorectal excision for rectal cancer? A case-matched study }\end{array}$ \\
\hline Matsubara & 2014 & $\begin{array}{l}\text { Mortality after common rectal surgery in Japan: a study on low anterior resection from } \\
\text { a newly established nationwide large-scale clinical database }\end{array}$ \\
\hline Martellucci & 2014 & $\begin{array}{l}\text { Laparoscopic total mesorectal excision for extraperitoneal rectal cancer: long-term } \\
\text { results }\end{array}$ \\
\hline Maggiori & 2014 & $\begin{array}{l}\text { Does pathologic response of rectal cancer influence postoperative morbidity after } \\
\text { neoadjuvant radiochemotherapy and total mesorectal excision? }\end{array}$ \\
\hline Liu & 2014 & $\begin{array}{l}\text { A scoring system to predict the risk of anastomotic leakage after anterior resection for } \\
\text { rectal cancer }\end{array}$ \\
\hline Liang & 2014 & $\begin{array}{l}\text { Surgical technique of robotic D3 lymph node dissection around the inferior mesenteric } \\
\text { artery with preservation of the left colic artery and autonomic nerves for the treatment } \\
\text { of distal rectal cancer }\end{array}$ \\
\hline Leahy & 2014 & What is the risk of clinical anastomotic leak in the diverted colorectal anastomosis? \\
\hline Kwag & 2014 & $\begin{array}{l}\text { Niti CAR } 27 \text { Versus a Conventional End-to-End Anastomosis Stapler in a Laparoscopic } \\
\text { Anterior Resection for Sigmoid Colon Cancer }\end{array}$ \\
\hline Krarup & 2014 & $\begin{array}{l}\text { Anastomotic leak increases distant recurrence and long-term mortality after curative } \\
\text { resection for colonic cancer: a nationwide cohort study }\end{array}$ \\
\hline Krarup & 2014 & Management of anastomotic leakage in a nationwide cohort of colonic cancer patients \\
\hline Kornmann & 2014 & Compromised visceral circulation does not affect the outcome of colorectal surgery \\
\hline Kornmann & 2014 & Beware of false-negative CT scan for anastomotic leakage after colonic surgery \\
\hline Komen & 2014 & $\begin{array}{l}\text { Polymerase chain reaction for Enterococcus faecalis in drain fluid: the first screening } \\
\text { test for symptomatic colorectal anastomotic leakage. The Appeal-study: analysis of } \\
\text { parameters predictive for evident anastomotic leakage }\end{array}$ \\
\hline Komen & 2014 & $\begin{array}{l}\text { Acute phase proteins in drain fluid: a new screening tool for colorectal anastomotic } \\
\text { leakage? The APPEAL study: analysis of parameters predictive for evident anastomotic } \\
\text { leakage }\end{array}$ \\
\hline Kobayashi & 2014 & $\begin{array}{l}\text { Risk factors for anastomotic leakage and favorable antimicrobial treatment as empirical } \\
\text { therapy for intra-abdominal infection in patients undergoing colorectal surgery }\end{array}$ \\
\hline Kawada & 2014 & $\begin{array}{l}\text { Risk factors for anastomotic leakage after laparoscopic low anterior resection with DST } \\
\text { anastomosis }\end{array}$ \\
\hline Kaser & 2014 & $\begin{array}{l}\text { Could hyponatremia be a marker of anastomotic leakage after colorectal surgery? A } \\
\text { single center analysis of } 1,106 \text { patients over } 5 \text { years }\end{array}$ \\
\hline Hua & 2014 & Defunctioning cannula ileostomy after lower anterior resection of rectal cancer \\
\hline Hicks & 2014 & $\begin{array}{l}\text { Does intramesorectal proctectomy with rectal eversion affect postoperative } \\
\text { complications compared to standard total mesorectal excision in patients with } \\
\text { ulcerative colitis? }\end{array}$ \\
\hline Henneman & 2014 & $\begin{array}{l}\text { Safety of elective colorectal cancer surgery: non-surgical complications and colectomies } \\
\text { are targets for quality improvement }\end{array}$ \\
\hline Hammond & 2014 & $\begin{array}{l}\text { The burden of gastrointestinal anastomotic leaks: an evaluation of clinical and economic } \\
\text { outcomes }\end{array}$ \\
\hline Giaccaglia & 2014 & $\begin{array}{l}\text { Procalcitonin, as an early biomarker of colorectal anastomotic leak, facilitates enhanced } \\
\text { recovery after surgery }\end{array}$ \\
\hline
\end{tabular}


Table S3.2 (continued)

\begin{tabular}{|c|c|c|}
\hline Author & Year & Title \\
\hline Ganschow & 2014 & $\begin{array}{l}\text { Early postoperative complications after stapled vs handsewn restorative } \\
\text { proctocolectomy with ileal pouch-anal anastomosis in } 148 \text { patients with familial } \\
\text { adenomatous polyposis coli: a matched-pair analysis }\end{array}$ \\
\hline Eyvazzadeh & 2014 & Outcomes after transanal endoscopic microsurgery with intraperitoneal anastomosis \\
\hline Ellebaek & 2014 & $\begin{array}{l}\text { Cytokine response in peripheral blood indicates different pathophysiological } \\
\text { mechanisms behind anastomotic leakage after low anterior resection: a pilot study }\end{array}$ \\
\hline Dinc & 2014 & Comparing methods of ileostomy closure constructed in colorectal surgery in Turkey \\
\hline De Raffele & 2014 & $\begin{array}{l}\text { Intermittent clamping of the hepatic pedicle in simultaneous ultrasonography-guided } \\
\text { liver resection and colorectal resection with intestinal anastomosis: is it safe? }\end{array}$ \\
\hline Dauser & 2014 & $\begin{array}{l}\text { Diagnosis, management and outcome of early anastomotic leakage following colorectal } \\
\text { anastomosis using a compression device: is it different? }\end{array}$ \\
\hline Cooper & 2014 & $\begin{array}{l}\text { Outcomes of the use of fully covered esophageal self-expandable stent in the } \\
\text { management of colorectal anastomotic strictures and leaks }\end{array}$ \\
\hline Bugiantella & 2014 & $\begin{array}{l}\text { Traditional lateral ileostomy versus percutaneous ileostomy by exclusion probe for the } \\
\text { protection of extraperitoneal colo-rectal anastomosis: the ALPPI (Anastomotic Leak } \\
\text { Prevention by Probe lleostomy) trial. A randomized controlled trial }\end{array}$ \\
\hline Boelens & 2014 & $\begin{array}{l}\text { Reduction of postoperative ileus by early enteral nutrition in patients undergoing major } \\
\text { rectal surgery: prospective, randomized, controlled trial }\end{array}$ \\
\hline Blumetti & 2014 & $\begin{array}{l}\text { Management of anastomotic leak: lessons learned from a large colon and rectal surgery } \\
\text { training program }\end{array}$ \\
\hline Binnebosel & 2014 & $\begin{array}{l}\text { Influence of CD68+ macrophages and neutrophils on anastomotic healing following } \\
\text { laparoscopic sigmoid resection due to diverticulitis }\end{array}$ \\
\hline $\begin{array}{l}\text { Banaszkiewic } \\
\text { z }\end{array}$ & 2014 & $\begin{array}{l}\text { Colorectal cancer with intestinal perforation - a retrospective analysis of treatment } \\
\text { outcomes }\end{array}$ \\
\hline Bakker & 2014 & $\begin{array}{l}\text { High complication rate after low anterior resection for mid and high rectal cancer; } \\
\text { results of a population-based study }\end{array}$ \\
\hline Bakker & 2014 & $\begin{array}{l}\text { Risk factors for anastomotic leakage and leak-related mortality after colonic cancer } \\
\text { surgery in a nationwide audit }\end{array}$ \\
\hline Anjaria & 2014 & $\begin{array}{l}\text { Management of colonic injuries in the setting of damage-control laparotomy: one shot } \\
\text { to get it right }\end{array}$ \\
\hline Ahmed Ali & 2014 & $\begin{array}{l}\text { Actual versus estimated length of stay after colorectal surgery: which factors influence a } \\
\text { deviation? }\end{array}$ \\
\hline Adams & 2014 & $\begin{array}{l}\text { Creation of an effective colorectal anastomotic leak early detection tool using an } \\
\text { artificial neural network }\end{array}$ \\
\hline Zhao & 2013 & $\begin{array}{l}\text { Use of a transanal drainage tube for prevention of anastomotic leakage and bleeding } \\
\text { after anterior resection for rectal cancer }\end{array}$ \\
\hline Trencheva & 2013 & $\begin{array}{l}\text { Identifying important predictors for anastomotic leak after colon and rectal resection: } \\
\text { prospective study on } 616 \text { patients }\end{array}$ \\
\hline Tan & 2013 & $\begin{array}{l}\text { American Society of Anesthesiologists class and Charlson's comorbidity index as } \\
\text { predictors of postoperative colorectal anastomotic leak: a single-institution experience }\end{array}$ \\
\hline Snijders & 2013 & $\begin{array}{l}\text { An increasing use of defunctioning stomas after low anterior resection for rectal cancer. } \\
\text { Is this the way to go? }\end{array}$ \\
\hline Snijders & 2013 & Anastomotic leakage as an outcome measure for quality of colorectal cancer surgery \\
\hline Smith & 2013 & $\begin{array}{l}\text { Anastomotic leak following low anterior resection in stage IV rectal cancer is associated } \\
\text { with poor survival }\end{array}$ \\
\hline $\begin{array}{l}\text { Sirois- } \\
\text { Giguere }\end{array}$ & 2013 & $\begin{array}{l}\text { Transanal drainage to treat anastomotic leaks after low anterior resection for rectal } \\
\text { cancer: a valuable option }\end{array}$ \\
\hline
\end{tabular}


Table S3.2 (continued)

\begin{tabular}{|c|c|c|}
\hline Author & Year & Title \\
\hline Seo & 2013 & The Role of Diverting Stoma After an Ultra-low Anterior Resection for Rectal Cancer \\
\hline Seo & 2013 & $\begin{array}{l}\text { Characteristics and risk factors associated with permanent stomas after sphincter-saving } \\
\text { resection for rectal cancer }\end{array}$ \\
\hline Saber & 2013 & $\begin{array}{l}\text { Efficacy of protective tube cecostomy after restorative resection for colorectal cancer: a } \\
\text { randomized trial }\end{array}$ \\
\hline Pasic & 2013 & $\begin{array}{l}\text { Predictive score for anastomotic leakage after elective colorectal cancer surgery: a } \\
\text { decision making tool for choice of protective measures }\end{array}$ \\
\hline Park & 2013 & $\begin{array}{l}\text { Multicenter analysis of risk factors for anastomotic leakage after laparoscopic rectal } \\
\text { cancer excision: the Korean laparoscopic colorectal surgery study group }\end{array}$ \\
\hline Ortiz & 2013 & $\begin{array}{l}\text { Impact of a multidisciplinary team training programme on rectal cancer outcomes in } \\
\text { Spain }\end{array}$ \\
\hline Okoshi & 2013 & $\begin{array}{l}\text { Efficacy of transanal drainage for anastomotic leakage after laparoscopic low anterior } \\
\text { resection of the rectum }\end{array}$ \\
\hline Nerup & 2013 & $\begin{array}{l}\text { Promising results after endoscopic vacuum treatment of anastomotic leakage following } \\
\text { resection of rectal cancer with ileostomy }\end{array}$ \\
\hline Nakajima & 2013 & $\begin{array}{l}\text { Efficacy of the predicted operation time (POT) strategy for synchronous colorectal liver } \\
\text { metastasis (SCLM): feasibility study for staged resection in patients with a long POT }\end{array}$ \\
\hline Morse & 2013 & $\begin{array}{l}\text { Determination of independent predictive factors for anastomotic leak: analysis of } 682 \\
\text { intestinal anastomoses }\end{array}$ \\
\hline Morks & 2013 & Late anastomotic leakage in colorectal surgery: a significant problem \\
\hline Lai & 2013 & $\begin{array}{l}\text { Risk factors for anastomotic leakage following anterior resection for colorectal cancer: } \\
\text { the effect of epidural analgesia on occurrence }\end{array}$ \\
\hline Kulu & 2013 & $\begin{array}{l}\text { Validation of the International Study Group of Rectal Cancer definition and severity } \\
\text { grading of anastomotic leakage }\end{array}$ \\
\hline Fischer & 2013 & $\begin{array}{l}\text { Vasopressor use after initial damage control laparotomy increases risk for anastomotic } \\
\text { disruption in the management of destructive colon injuries }\end{array}$ \\
\hline Kim & 2013 & $\begin{array}{l}\text { Comparison of intracorporeal single-stapled and double-stapled anastomosis in } \\
\text { laparoscopic low anterior resection for rectal cancer: a case-control study }\end{array}$ \\
\hline Kang & 2013 & A nationwide analysis of laparoscopy in high-risk colorectal surgery patients \\
\hline Jafari & 2013 & $\begin{array}{l}\text { The use of indocyanine green fluorescence to assess anastomotic perfusion during } \\
\text { robotic assisted laparoscopic rectal surgery }\end{array}$ \\
\hline Genser & 2013 & $\begin{array}{l}\text { Postoperative and long-term outcomes after redo surgery for failed colorectal or } \\
\text { coloanal anastomosis: retrospective analysis of } 50 \text { patients and review of the literature }\end{array}$ \\
\hline Garude & 2013 & Single layered intestinal anastomosis: a safe and economic technique \\
\hline $\begin{array}{l}\text { Garcia- } \\
\text { Granero }\end{array}$ & 2013 & $\begin{array}{l}\text { Procalcitonin and C-reactive protein as early predictors of anastomotic leak in colorectal } \\
\text { surgery: a prospective observational study }\end{array}$ \\
\hline Floodeen & 2013 & $\begin{array}{l}\text { Early and late symptomatic anastomotic leakage following low anterior resection of the } \\
\text { rectum for cancer: are they different entities? }\end{array}$ \\
\hline Dumont & 2013 & Options and outcome for reconstruction after extended left hemicolectomy \\
\hline Dinnewitzer & 2013 & $\begin{array}{l}\text { Cumulative incidence of permanent stoma after sphincter preserving low anterior } \\
\text { resection of mid and low rectal cancer }\end{array}$ \\
\hline den Dulk & 2013 & The DULK (Dutch leakage) and modified DULK score compared: actively seek the leak \\
\hline Caulfield & 2013 & Anastomotic leak after low anterior resection: a spectrum of clinical entities \\
\hline Boesen & 2013 & $\begin{array}{l}\text { Perioperative fluid infusion and its influence on anastomotic leakage after rectal cancer } \\
\text { surgery: implications for prevention strategies }\end{array}$ \\
\hline Bisgard & 2013 & $\begin{array}{l}\text { Perioperative statin therapy is not associated with reduced risk of anastomotic leakage } \\
\text { after colorectal resection }\end{array}$ \\
\hline Biondo & 2013 & $\begin{array}{l}\text { Long-term functional results from a randomized clinical study of transverse coloplasty } \\
\text { compared with colon J-pouch after low anterior resection for rectal cancer }\end{array}$ \\
\hline
\end{tabular}


Table S3.2 (continued)

\begin{tabular}{|c|c|c|}
\hline Author & Year & Title \\
\hline Aytac & 2013 & $\begin{array}{l}\text { Impact of stress dose steroids on the outcomes of restorative proctocolectomy in } \\
\text { patients with ulcerative colitis }\end{array}$ \\
\hline Aytac & 2013 & $\begin{array}{l}\text { Impact of obesity on operation performed, complications, and long-term outcomes in } \\
\text { terms of restoration of intestinal continuity for patients with mid and low rectal cancer }\end{array}$ \\
\hline Asoglu & 2013 & Laparoscopic surgery for rectal cancer: outcomes in 513 patients \\
\hline Ashraf & 2013 & $\begin{array}{l}\text { The economic impact of anastomotic leakage after anterior resections in English NHS } \\
\text { hospitals: are we adequately remunerating them? }\end{array}$ \\
\hline Ashburn & 2013 & $\begin{array}{l}\text { Consequences of anastomotic leak after restorative proctectomy for cancer: effect on } \\
\text { long-term function and quality of life }\end{array}$ \\
\hline Smith & 2012 & $\begin{array}{l}\text { Anastomotic leak is not associated with oncologic outcome in patients undergoing low } \\
\text { anterior resection for rectal cancer }\end{array}$ \\
\hline Van't Sant & 2012 & $\begin{array}{l}\text { The influence of mechanical bowel preparation in elective colorectal surgery for } \\
\text { diverticulitis }\end{array}$ \\
\hline Slieker & 2012 & $\begin{array}{l}\text { Long-term and perioperative corticosteroids in anastomotic leakage: a prospective } \\
\text { study of } 259 \text { left-sided colorectal anastomoses }\end{array}$ \\
\hline Schietroma & 2012 & $\begin{array}{l}\text { Colorectal Infraperitoneal anastomosis: the effects of perioperative supplemental } \\
\text { oxygen administration on the anastomotic dehiscence }\end{array}$ \\
\hline Rutegard & 2012 & $\begin{array}{l}\text { High tie in anterior resection for rectal cancer confers no increased risk of anastomotic } \\
\text { leakage }\end{array}$ \\
\hline Ruffo & 2012 & $\begin{array}{l}\text { Laparoscopic rectal resection for severe endometriosis of the mid and low rectum: } \\
\text { technique and operative results }\end{array}$ \\
\hline Rondelli & 2012 & $\begin{array}{l}\text { Temporary percutaneous ileostomy versus conventional loop ileostomy in mechanical } \\
\text { extraperitoneal colorectal anastomosis: a retrospective study }\end{array}$ \\
\hline Richards & 2012 & $\begin{array}{l}\text { Smoking is a major risk factor for anastomotic leak in patients undergoing low anterior } \\
\text { resection }\end{array}$ \\
\hline Post & 2012 & $\begin{array}{l}\text { Intraoperative blood pressure changes as a risk factor for anastomotic leakage in } \\
\text { colorectal surgery }\end{array}$ \\
\hline Platt & 2012 & $\begin{array}{l}\text { C-reactive protein as a predictor of postoperative infective complications after curative } \\
\text { resection in patients with colorectal cancer }\end{array}$ \\
\hline Piessen & 2012 & $\begin{array}{l}\text { Previous transanal full-thickness excision increases the morbidity of radical resection for } \\
\text { rectal cancer }\end{array}$ \\
\hline Penninckx & 2012 & $\begin{array}{l}\text { Risk adjusted benchmarking of clinical anastomotic leakage rate after total mesorectal } \\
\text { excision in the context of an improvement project }\end{array}$ \\
\hline Pedersen & 2012 & $\begin{array}{l}\text { Increased levels of C-reactive protein and leukocyte count are poor predictors of } \\
\text { anastomotic leakage following laparoscopic colorectal resection }\end{array}$ \\
\hline Ogilvie & 2012 & $\begin{array}{l}\text { Anastomotic leak after restorative proctosigmoidectomy for cancer: what are the } \\
\text { chances of a permanent ostomy? }\end{array}$ \\
\hline Nisar & 2012 & $\begin{array}{l}\text { Influence of neoadjuvant radiotherapy on anastomotic leak after restorative resection } \\
\text { for rectal cancer }\end{array}$ \\
\hline Nakajima & 2012 & $\begin{array}{l}\text { Predictive factors for anastomotic leakage after simultaneous resection of synchronous } \\
\text { colorectal liver metastasis }\end{array}$ \\
\hline Millan & 2012 & Risk factors for prolonged postoperative ileus after colorectal cancer surgery \\
\hline Manceau & 2012 & $\begin{array}{l}\text { Right colon to rectal anastomosis (Deloyers procedure) as a salvage technique for low } \\
\text { colorectal or coloanal anastomosis: postoperative and long-term outcomes }\end{array}$ \\
\hline Leichtle & 2012 & Risk factors for anastomotic leakage after colectomy \\
\hline Lagoutte & 2012 & $\begin{array}{l}\text { C-reactive protein and procalcitonin for the early detection of anastomotic leakage after } \\
\text { elective colorectal surgery: pilot study in } 100 \text { patients }\end{array}$ \\
\hline Krarup & 2012 & A nationwide study on anastomotic leakage after colonic cancer surgery \\
\hline
\end{tabular}


Table S3.2 (continued)

\begin{tabular}{|c|c|c|}
\hline Author & Year & Title \\
\hline Klein & 2012 & $\begin{array}{l}\text { Postoperative use of non-steroidal anti-inflammatory drugs in patients with anastomotic } \\
\text { leakage requiring reoperation after colorectal resection: cohort study based on } \\
\text { prospective data }\end{array}$ \\
\hline Kanazawa & 2012 & $\begin{array}{l}\text { Risk factors for postoperative intra-abdominal septic complications after bowel } \\
\text { resection in patients with Crohn's disease }\end{array}$ \\
\hline Gorissen & 2012 & $\begin{array}{l}\text { Risk of anastomotic leakage with non-steroidal anti-inflammatory drugs in colorectal } \\
\text { surgery }\end{array}$ \\
\hline Fauno & 2012 & Low complication rate after stoma closure. Consultants attended $90 \%$ of the operations \\
\hline Blumetti & 2012 & $\begin{array}{l}\text { Delayed transanal repair of persistent coloanal anastomotic leak in diverted patients } \\
\text { after resection for rectal cancer }\end{array}$ \\
\hline Biondo & 2012 & $\begin{array}{l}\text { Risk factors for surgical site infection after elective resection for rectal cancer. A } \\
\text { multivariate analysis on } 2131 \text { patients }\end{array}$ \\
\hline Bakker & 2012 & $\begin{array}{l}\text { The C-seal trial: colorectal anastomosis protected by a biodegradable drain fixed to the } \\
\text { anastomosis by a circular stapler, a multi-center randomized controlled trial }\end{array}$ \\
\hline Almeida & 2012 & $\begin{array}{l}\text { Elevated serum C-reactive protein as a predictive factor for anastomotic leakage in } \\
\text { colorectal surgery }\end{array}$ \\
\hline Xiao & 2011 & $\begin{array}{l}\text { Can transanal tube placement after anterior resection for rectal carcinoma reduce } \\
\text { anastomotic leakage rate? A single-institution prospective randomized study }\end{array}$ \\
\hline Warschkow & 2011 & $\begin{array}{l}\text { Epidural analgesia in open resection of colorectal cancer: is there a clinical benefit? a } \\
\text { retrospective study on } 1,470 \text { patients }\end{array}$ \\
\hline Trenti & 2011 & $\begin{array}{l}\text { Generalized peritonitis due to perforated diverticulitis: Hartmann's procedure or } \\
\text { primary anastomosis? }\end{array}$ \\
\hline Thornton & 2011 & Management and outcome of colorectal anastomotic leaks \\
\hline Sule & 2011 & Adult large bowel obstruction: a review of clinical experience \\
\hline Shiomi & 2011 & $\begin{array}{l}\text { Diverting stoma in rectal cancer surgery. A retrospective study of } 329 \text { patients from } \\
\text { Japanese cancer centers }\end{array}$ \\
\hline Shiomi & 2011 & $\begin{array}{l}\text { The indications for a diverting stoma in low anterior resection for rectal cancer: a } \\
\text { prospective multicentre study of } 222 \text { patients from Japanese cancer centers }\end{array}$ \\
\hline Schnuriger & 2011 & $\begin{array}{l}\text { Crystalloids after primary colon resection and anastomosis at initial trauma laparotomy: } \\
\text { excessive volumes are associated with anastomotic leakage }\end{array}$ \\
\hline Penninckx & 2011 & $\begin{array}{l}\text { Anastomotic leakage: a disaster or a challenge with an impact on survival after rectal } \\
\text { cancer surgery? }\end{array}$ \\
\hline Park & 2011 & $\begin{array}{l}\text { S052: a comparison of robot-assisted, laparoscopic, and open surgery in the treatment } \\
\text { of rectal cancer }\end{array}$ \\
\hline Maggiori & 2011 & $\begin{array}{l}\text { Conservative management is associated with a decreased risk of definitive stoma after } \\
\text { anastomotic leakage complicating sphincter-saving resection for rectal cancer }\end{array}$ \\
\hline Maggiori & 2011 & $\begin{array}{l}\text { Laparoscopic colorectal anastomosis using the novel Chex((R)) circular stapler: a case- } \\
\text { control study }\end{array}$ \\
\hline Lindgren & 2011 & $\begin{array}{l}\text { What is the risk for a permanent stoma after low anterior resection of the rectum for } \\
\text { cancer? A six-year follow-up of a multicenter trial }\end{array}$ \\
\hline Lindgren & 2011 & $\begin{array}{l}\text { Does a defunctioning stoma affect anorectal function after low rectal resection? Results } \\
\text { of a randomized multicenter trial }\end{array}$ \\
\hline Lin & 2011 & $\begin{array}{l}\text { The influence of fecal diversion and anastomotic leakage on survival after resection of } \\
\text { rectal cancer }\end{array}$ \\
\hline Levack & 2011 & Laparoscopy decreases anastomotic leak rate in sigmoid colectomy for diverticulitis \\
\hline Lehmann & 2011 & $\begin{array}{l}\text { Does sacrifice of the inferior mesenteric artery or superior rectal artery affect } \\
\text { anastomotic leak following sigmoidectomy for diverticulitis? a retrospective review }\end{array}$ \\
\hline Kumar & 2011 & Anterior resection for rectal carcinoma - risk factors for anastomotic leaks and strictures \\
\hline
\end{tabular}


Table S3.2 (continued)

\begin{tabular}{|c|c|c|}
\hline Author & Year & Title \\
\hline Kruschewski & 2011 & $\begin{array}{l}\text { Management and results of complications after anterior resection with colonic pouch } \\
\text { reconstruction for rectal cancer }\end{array}$ \\
\hline Katoh & 2011 & $\begin{array}{l}\text { Anastomotic leakage contributes to the risk for systemic recurrence in stage II colorectal } \\
\text { cancer }\end{array}$ \\
\hline Jurado & 2011 & $\begin{array}{l}\text { Low colorectal anastomosis after pelvic exenteration for gynecologic malignancies: risk } \\
\text { factors analysis for leakage }\end{array}$ \\
\hline Jorgren & 2011 & $\begin{array}{l}\text { Anastomotic leakage after surgery for rectal cancer: a risk factor for local recurrence, } \\
\text { distant metastasis and reduced cancer-specific survival? }\end{array}$ \\
\hline Gulla & 2011 & Ghost ileostomy after anterior resection for rectal cancer: a preliminary experience \\
\hline Good & 2011 & Laparoscopic surgery for rectal cancer: a single-centre experience of 120 cases \\
\hline Gadiot & 2011 & $\begin{array}{l}\text { Reduction of anastomotic failure in laparoscopic colorectal surgery using antitraction } \\
\text { sutures }\end{array}$ \\
\hline Frago & 2011 & $\begin{array}{l}\text { Differences between proximal and distal obstructing colonic cancer after curative } \\
\text { surgery }\end{array}$ \\
\hline Fouda & 2011 & Early detection of anastomotic leakage after elective low anterior resection \\
\hline Fong & 2011 & $\begin{array}{l}\text { Chronic anastomotic sinus after low anterior resection: when can the defunctioning } \\
\text { stoma be reversed? }\end{array}$ \\
\hline Dekker & 2011 & $\begin{array}{l}\text { Predicting the risk of anastomotic leakage in left-sided colorectal surgery using a colon } \\
\text { leakage score }\end{array}$ \\
\hline Cerroni & 2011 & Ghost lleostomy with or without abdominal parietal split \\
\hline Buchberg & 2011 & $\begin{array}{l}\text { The use of a compression device as an alternative to hand-sewn and stapled colorectal } \\
\text { anastomoses: is three a crowd? }\end{array}$ \\
\hline Antolovic & 2011 & $\begin{array}{l}\text { Restoration of intestinal continuity after Hartmann's procedure--not a benign operation. } \\
\text { Are there predictors for morbidity? }\end{array}$ \\
\hline Woeste & 2010 & $\begin{array}{l}\text { Increased serum levels of C-reactive protein precede anastomotic leakage in colorectal } \\
\text { surgery }\end{array}$ \\
\hline Wang & 2010 & $\begin{array}{l}\text { Risk factors for symptomatic anastomotic leakage after low anterior resection for rectal } \\
\text { cancer with } 30 \mathrm{~Gy} / 10 \mathrm{f} / 2 \mathrm{w} \text { preoperative radiotherapy }\end{array}$ \\
\hline $\begin{array}{l}\text { Vergara- } \\
\text { Fernandez }\end{array}$ & 2010 & $\begin{array}{l}\text { Assessing outcomes following surgery for colorectal cancer using quality of care } \\
\text { indicators }\end{array}$ \\
\hline Telem & 2010 & $\begin{array}{l}\text { Diagnosis of gastrointestinal anastomotic dehiscence after hospital discharge: Impact on } \\
\text { patient management and outcome }\end{array}$ \\
\hline Telem & 2010 & Risk factors for anastomotic leak following colorectal surgery: a case-control study \\
\hline Shin & 2010 & Delayed anastomotic leakage following sphincter-preserving surgery for rectal cancer \\
\hline $\begin{array}{l}\text { Pramateftaki } \\
\mathrm{s}\end{array}$ & 2010 & The handsewn anastomosis after colon resection due to colonic cancer \\
\hline Pasternak & 2010 & $\begin{array}{l}\text { Elevated intraperitoneal matrix metalloproteinases- } 8 \text { and }-9 \text { in patients who develop } \\
\text { anastomotic leakage after rectal cancer surgery: a pilot study }\end{array}$ \\
\hline $\begin{array}{l}\text { Ortega- } \\
\text { Deballon }\end{array}$ & 2010 & $\begin{array}{l}\text { C-reactive protein is an early predictor of septic complications after elective colorectal } \\
\text { surgery }\end{array}$ \\
\hline Matthiessen & 2010 & $\begin{array}{l}\text { Symptomatic anastomotic leakage diagnosed after hospital discharge following low } \\
\text { anterior resection for rectal cancer }\end{array}$ \\
\hline Matthiessen & 2010 & $\begin{array}{l}\text { Anastomotic-vaginal fistula (AVF) after anterior resection of the rectum for cancer-- } \\
\text { occurrence and risk factors }\end{array}$ \\
\hline Kim & 2010 & $\begin{array}{l}\text { Complications after sphincter-saving resection in rectal cancer patients according to } \\
\text { whether chemoradiotherapy is performed before or after surgery }\end{array}$ \\
\hline Kanellos & 2010 & Anastomotic leakage following low anterior resection for rectal cancer \\
\hline Kanellos & 2010 & Anastomotic leakage after colonic resection \\
\hline
\end{tabular}


Table S3.2 (continued)

\begin{tabular}{|c|c|c|}
\hline Author & Year & Title \\
\hline Jeong & 2010 & $\begin{array}{l}\text { Cefotetan versus conventional triple antibiotic prophylaxis in elective colorectal cancer } \\
\text { surgery }\end{array}$ \\
\hline Hidalgo & 2010 & Laparoscopic rectal surgery: does immediate outcome differ in respect to sex? \\
\hline El-Gazzaz & 2010 & Risk of clinical leak after laparoscopic versus open bowel anastomosis \\
\hline Ciga & 2010 & $\begin{array}{l}\text { Comparative study of one-stage colectomy of the descending colon in emergency and } \\
\text { elective surgery without mechanical preparation }\end{array}$ \\
\hline Choi & 2010 & Risk factors for anastomotic leakage after laparoscopic rectal resection \\
\hline Biondo & 2010 & Impact of surgical specialization on emergency colorectal surgery outcomes \\
\hline Bertelsen & 2010 & Anastomotic leakage after anterior resection for rectal cancer: risk factors \\
\hline Bertelsen & 2010 & $\begin{array}{l}\text { Anastomotic leakage after curative anterior resection for rectal cancer: short and long- } \\
\text { term outcome }\end{array}$ \\
\hline Akasu & 2010 & $\begin{array}{l}\text { Risk factors for anastomotic leakage following intersphincteric resection for very low } \\
\text { rectal adenocarcinoma }\end{array}$ \\
\hline Ulrich & 2009 & Diverting stoma after low anterior resection: more arguments in favor \\
\hline $\begin{array}{l}\text { Szynglarewic } \\
\text { z }\end{array}$ & 2009 & $\begin{array}{l}\text { The impact of pre- or postoperative radiochemotherapy on complication following } \\
\text { anterior resection with en bloc excision of female genitalia for T4 rectal cancer }\end{array}$ \\
\hline Saha & 2009 & Morbidity and mortality after closure of loop ileostomy \\
\hline Roos & 2009 & $\begin{array}{l}\text { Perioperative selective decontamination of the digestive tract (SDD) in elective } \\
\text { colorectal surgery }\end{array}$ \\
\hline Ricciardi & 2009 & Anastomotic leak testing after colorectal resection: what are the data? \\
\hline Cheung & 2009 & $\begin{array}{l}\text { Endolaparoscopic Approach vs Conventional Open Surgery in the Treatment of } \\
\text { Obstructing Left-Sided Colon Cancer }\end{array}$ \\
\hline Frye & 2009 & $\begin{array}{l}\text { Anastomotic leakage after resection of colorectal cancer generates prodigious use of } \\
\text { hospital resources }\end{array}$ \\
\hline Li & 2009 & $\begin{array}{l}\text { Use of routine intraoperative endoscopy in elective laparoscopic colorectal surgery: can } \\
\text { it further avoid anastomotic failure? }\end{array}$ \\
\hline Komen & 2009 & $\begin{array}{l}\text { Detection of colon flora in peritoneal drain fluid after colorectal surgery: Can RT-PCR } \\
\text { play a role in diagnosing anastomotic leakage? }\end{array}$ \\
\hline Marra & 2009 & $\begin{array}{l}\text { Anastomotic leakage as a risk factor for the long-term outcome after curative resection } \\
\text { of colon cancer. }\end{array}$ \\
\hline Akiyoshi & 2009 & $\begin{array}{l}\text { Factors affecting the difficulty of laparoscopic total mesorectal excision with double } \\
\text { stapling technique anastomosis for low rectal cancer }\end{array}$ \\
\hline Komen & 2009 & After-hours colorectal surgery: a risk factor for anastomotic leakage \\
\hline Cong & 2009 & $\begin{array}{l}\text { Influencing Factors of Symptomatic Anastomotic Leakage After Anterior Resection of } \\
\text { the Rectum for Cancer }\end{array}$ \\
\hline Karlizcek & 2009 & Surgeons lack predictive accuracy for anastomotic leakage in gastrointestinal surgery \\
\hline Park & 2009 & $\begin{array}{l}\text { Multidimensional analysis of the learning curve for laparoscopic colorectal surgery: } \\
\text { lessons from } 1,000 \text { cases of laparoscopic colorectal surgery }\end{array}$ \\
\hline Damrauer & 2009 & Contained Anastomotic Leaks After Colorectal Surgery \\
\hline Dulk & 2009 & Improved diagnosis and treatment of anastomotic leakage after colorectal surgery \\
\hline Bellows & 2009 & Early predictors of anastomotic leaks after colectomy \\
\hline Park & 2009 & $\begin{array}{l}\text { Multidimensional Analysis of the Learning Curve for Laparoscopic Resection in Rectal } \\
\text { cancer }\end{array}$ \\
\hline Kingham & 2009 & Colonic Anastomotic Leak: Risk Factors, Diagnosis, and Treatment \\
\hline Choptra & 2009 & $\begin{array}{l}\text { The effect of endoscopic treatment on healing of anastomotic leaks after anterior } \\
\text { resection of rectal cancer }\end{array}$ \\
\hline Brisinda & 2009 & $\begin{array}{l}\text { End-to-End Versus End-to-Side Stapled Anastomoses After Anterior Resection for Rectal } \\
\text { Cancer }\end{array}$ \\
\hline
\end{tabular}


Table S3.2 (continued)

\begin{tabular}{|c|c|c|}
\hline Author & Year & Title \\
\hline Kim & 2009 & $\begin{array}{l}\text { Risk Factors for Anastomotic Leakage after Laparoscopic Intracorporeal Colorectal } \\
\text { Anastomosis with a Double Stapling Technique }\end{array}$ \\
\hline Eberhardt & 2009 & $\begin{array}{l}\text { The Impact of Anastomotic Leak and Intra-Abdominal Abscess on Cancer-Related } \\
\text { Outcomes After Resection for Colorectal Cancer: A Case Control Study }\end{array}$ \\
\hline Lian & 2009 & $\begin{array}{l}\text { Outcomes for Patients Developing Anastomotic Leak After lleal Pouch-Anal } \\
\text { Anastomosis: Does a Handsewn vs. Stapled Anastomosis Matter? }\end{array}$ \\
\hline Joh & 2009 & $\begin{array}{l}\text { Anastomotic Leakage after Laparoscopic Protectomy can be Managed by a Minimally } \\
\text { Invasive Approach }\end{array}$ \\
\hline Klein & 2009 & $\begin{array}{l}\text { Increased Risk of Anastomotic Leakage with Diclofenac Treatment after Laparoscopic } \\
\text { Colorectal Surgery }\end{array}$ \\
\hline Ulrich & 2008 & $\begin{array}{l}\text { Early results from a randomized clinical trial of colon J pouch versus transverse } \\
\text { coloplasty pouch after low anterior resection for rectal cancer }\end{array}$ \\
\hline Chessin & 2008 & $\begin{array}{l}\text { Septic Complications after Restorative Proctocolectomy do not Impair Functional } \\
\text { Outcome: Long-Term Follow-Up from a Specialty Center }\end{array}$ \\
\hline Jestin & 2008 & Risk factors for anastomotic leakage after rectal cancer surgery: a case-control study \\
\hline Doeksen & 2008 & Radiological evaluation of colorectal anastomoses \\
\hline Martel & 2008 & $\begin{array}{l}\text { Neoadjuvant Therapy and Anastomotic Leak After Tumor-Specific Mesorectal Excision } \\
\text { for Rectal Cancer }\end{array}$ \\
\hline $\begin{array}{l}\text { Weidenhage } \\
\mathrm{n}\end{array}$ & 2008 & $\begin{array}{l}\text { Endoscopic vacuum-assisted closure of anastomotic leakage following anterior resection } \\
\text { of the rectum: a new method }\end{array}$ \\
\hline Ito & 2008 & $\begin{array}{l}\text { Relationship between multiple numbers of stapler firings during rectal division and } \\
\text { anastomotic leakage }\end{array}$ \\
\hline lancu & 2008 & $\begin{array}{l}\text { Host-Related Predictive Factors for Anastomotic Leakage Following Large Bowel } \\
\text { Resections for Colorectal Cancer* }\end{array}$ \\
\hline Khan & 2008 & The management and outcome of anastomotic leaks in colorectal surgery \\
\hline Lee & 2008 & $\begin{array}{l}\text { Risk Factors and Clinical Outcome for Anastomotic Leakage After Total Mesorectal } \\
\text { Excision for Rectal Cancer }\end{array}$ \\
\hline Jung & 2008 & Risk Factors and Oncologic Impact of Anastomotic Leakage after Rectal Cancer Surgery \\
\hline Williams & 2008 & The outcome of loop ileostomy closure: a prospective study \\
\hline Lim & 2008 & $\begin{array}{l}\text { Outcomes of colorectal anastomoses during pelvic exenteration for gynaecological } \\
\text { malignancy }\end{array}$ \\
\hline Tsuijnaka & 2008 & Pelvic drainage for anterior resection revisited: use of drains in anastomotic leaks \\
\hline Wilson & 2008 & $\begin{array}{l}\text { Comparative Costs of Ertapenem and Cefotetan as Prophylaxis for Elective Colorectal } \\
\text { Surgery }\end{array}$ \\
\hline Buchs & 2008 & $\begin{array}{l}\text { Incidence, consequences, and risk factors for anastomotic dehiscence after colorectal } \\
\text { surgery: a prospective monocentric study }\end{array}$ \\
\hline Glitsch & 2008 & $\begin{array}{l}\text { Endoscopic transanal vacuum-assisted rectal drainage (ETVARD): an optimized therapy } \\
\text { for major leaks from extraperitoneal rectal anastomoses }\end{array}$ \\
\hline Steffen & 2008 & $\begin{array}{l}\text { Safety and morbidity after ultra-low coloanal anastomoses: J-pouch vs end-to-end } \\
\text { reconstruction }\end{array}$ \\
\hline Ye & 2008 & $\begin{array}{l}\text { Use of Intracolonic Bypass Secured by a Biodegradable Anastomotic Ring to Protect the } \\
\text { Low Rectal Anastomosis }\end{array}$ \\
\hline Matthiessen & 2008 & $\begin{array}{l}\text { Increase of serum C-reactive protein is an early indicator of subsequent symptomatic } \\
\text { anastomotic leakage after anterior resection }\end{array}$ \\
\hline Contant & 2007 & $\begin{array}{l}\text { Mechanical bowel preparation for elective colorectal surgery: a multicentre randomised } \\
\text { trial }\end{array}$ \\
\hline Wind & 2007 & $\begin{array}{l}\text { Laparoscopic reintervention for anastomotic leakage after primary laparoscopic } \\
\text { colorectal surgery }\end{array}$ \\
\hline
\end{tabular}


Table S3.2 (continued)

\begin{tabular}{|c|c|c|}
\hline Author & Year & Title \\
\hline Welsch & 2007 & $\begin{array}{l}\text { C-reactive protein as early predictor for infectious postoperative complications in rectal } \\
\text { surgery }\end{array}$ \\
\hline Veyrie & 2007 & $\begin{array}{l}\text { Anastomotic Leakage after Elective Right Versus Left Colectomy for Cancer: Prevalence } \\
\text { and Independent Risk Factors }\end{array}$ \\
\hline Ptok & 2007 & Impact of anastomotic leakage on oncological outcome after rectal cancer resection \\
\hline O'Grady & 2007 & Colorectal cancer manasgement in the provincial New Zealand setting of Nelson \\
\hline Samson & 2007 & Colorectal resection in peripheral New Zealand: workload, outcomes and its future \\
\hline Bretagnol & 2007 & Rectal cancer surgery without mechanical bowel preparation \\
\hline Matthiessen & 2007 & $\begin{array}{l}\text { Is Early Detection of Anastomotic Leakage Possible by Intraperitoneal Microdialysis and } \\
\text { Intraperitoneal Cytokines After Anterior Resection of the Rectum for Cancer? }\end{array}$ \\
\hline Jones & 2007 & Low anastomotic leak rate after colorectal surgery: a single- centre study \\
\hline Staudacher & 2007 & $\begin{array}{l}\text { Laparoscopic vs. Open Total Mesorectal Excision in Unselected Patients with Rectal } \\
\text { Cancer: Impact on Early Outcome }\end{array}$ \\
\hline Vermaas & 2007 & $\begin{array}{l}\text { Introduction of preoperative radiotherapy in the treatment of operable rectal cancer in } \\
\text { the Southwest region of the Netherlands }\end{array}$ \\
\hline Kruschewski & 2007 & $\begin{array}{l}\text { Risk factors for clinical anastomotic leakage and postoperative mortality in elective } \\
\text { surgery for rectal cancer }\end{array}$ \\
\hline Kong & 2007 & $\begin{array}{l}\text { Selective treatment of rectal cancer with single-stage coloanal or ultralow colorectal } \\
\text { anastomosis does not adversely affect morbidity and mortality }\end{array}$ \\
\hline Matthiessen & 2007 & $\begin{array}{l}\text { Defunctioning Stoma Reduces Symptomatic Anastomotic Leakage After Low Anterior } \\
\text { Resection of the Rectum for Cancer }\end{array}$ \\
\hline Huh & 2007 & $\begin{array}{l}\text { A Diverting Stoma Is Not Necessary when Performing a Handsewn Coloanal Anastomosis } \\
\text { for Lower Rectal Cancer }\end{array}$ \\
\hline Oguz & 2007 & $\begin{array}{l}\text { L-Alanin-L-glutamine supplementation improves the outcome after colorectal surgery } \\
\text { for cancer }\end{array}$ \\
\hline Pena-Soria & 2007 & $\begin{array}{l}\text { Mechanical Bowel Preparation for Elective Colorectal Surgery with Primary } \\
\text { Intraperitoneal Anastomosis by a Single Surgeon: Interim Analysis of a Prospective } \\
\text { Single-Blinded Randomized Trial }\end{array}$ \\
\hline Marecik & 2007 & Single-stapled double-pursestring anastomosis after anterior resection of the rectum \\
\hline Brennan & 2007 & $\begin{array}{l}\text { Routine Mobilization of the Splenic Flexure is not Necessary During Anterior Resection } \\
\text { for Rectal Cancer }\end{array}$ \\
\hline Rickard & 2007 & Ileal pouch-anal anastomosis: the Australasian experience \\
\hline Nicksa & 2007 & Anastomotic Leaks: What is the Best Diagnostic Imaging Study? \\
\hline Law & 2007 & $\begin{array}{l}\text { Anastomotic Leakage is Associated with Poor Long-Term Outcome in Patients After } \\
\text { Curative Colorectal Resection for Malignancy }\end{array}$ \\
\hline Platell & 2007 & The incidence of anastomotic leaks in patients undergoing colorectal surgery \\
\hline Smith & 2007 & $\begin{array}{l}\text { The efficacy of intraoperative methylene blue enemas to assess the integrity of a colonic } \\
\text { anastomosis }\end{array}$ \\
\hline Shrikhande & 2007 & $\begin{array}{l}\text { Outcomes of resection for rectal cancer in India: The impact of the double stapling } \\
\text { technique }\end{array}$ \\
\hline $\begin{array}{l}\text { Rodriguez- } \\
\text { Ramirez }\end{array}$ & 2006 & $\begin{array}{l}\text { Risk factors for anastomotic leakage after preoperative chemoradiation therapy and low } \\
\text { anterior resection with total mesorectal excision for locally advanced rectal cancer }\end{array}$ \\
\hline Richardson & 2006 & Risk factors for anastomotic leak after recto-sigmoid resection for ovarian cancer \\
\hline Kim & 2006 & $\begin{array}{l}\text { Laparoscopic resection for rectal cancer: a prospective analysis of thirty-month follow- } \\
\text { up outcomes in } 312 \text { patients }\end{array}$ \\
\hline Zmora & 2006 & $\begin{array}{l}\text { Is mechanical bowel preparation mandatory for left-sided colonic anastomosis? Results } \\
\text { of a prospective randomized trial }\end{array}$ \\
\hline Bulow & 2006 & Transanal stent in anterior resection does not prevent anastomotic leakage \\
\hline
\end{tabular}


Table S3.2 (continued)

\begin{tabular}{|c|c|c|}
\hline Author & Year & Title \\
\hline Lim & 2006 & $\begin{array}{l}\text { Clinical and Subclinical Leaks After Low Colorectal Anastomosis: A Clinical and Radiologic } \\
\text { Study }\end{array}$ \\
\hline Byrn & 2006 & The Management of 38 Anastomotic Leaks After 1,684 Intestinal Resections \\
\hline Law & 2006 & $\begin{array}{l}\text { Laparoscopic and Open Anterior Resection for Upper and Mid Rectal Cancer: An } \\
\text { Evaluation of Outcomes }\end{array}$ \\
\hline Choi & 2006 & $\begin{array}{l}\text { Leakage After Resection and Intraperitoneal Anastomosis for Colorectal Malignancy: } \\
\text { Analysis of Risk Factors }\end{array}$ \\
\hline Lipska & 2006 & Anastomotic leakage after lower gastrointestinal anastomosis: men are at higher risk \\
\hline Millan & 2006 & Early Prediction of Anastomotic Leak in Colorectal Cancer Surgery by Intramucosal pH \\
\hline Matthiessen & 2006 & $\begin{array}{l}\text { Population-based study of risk factors for postoperative death after anterior resection } \\
\text { of the rectum }\end{array}$ \\
\hline Konishi & 2006 & $\begin{array}{l}\text { Risk Factors for Anastomotic Leakage after Surgery for Colorectal Cancer: Results of } \\
\text { Prospective Surveillance }\end{array}$ \\
\hline Korkolis & 2006 & $\begin{array}{l}\text { Short-term preoperative radiotherapy is a safe approach for treatment of locally } \\
\text { advanced rectal cancer }\end{array}$ \\
\hline Bernardshaw & 2006 & $\begin{array}{l}\text { Treatment of Rectal Cancer: Reduction of Local Recurrence after the Introduction of } \\
\text { TME - Experience from One University Hospital }\end{array}$ \\
\hline Fa-Si-Oen & 2005 & $\begin{array}{l}\text { Mechanical Bowel Preparation or Not? Outcome of a Multicenter, Randomized Trial in } \\
\text { Elective Open Colon Surgery }\end{array}$ \\
\hline Biondo & 2005 & $\begin{array}{l}\text { Anastomotic Dehiscence After Resection and Primary Anastomosis in Left-Sided Colonic } \\
\text { Emergencies }\end{array}$ \\
\hline McArdle & 2005 & $\begin{array}{l}\text { Impact of anastomotic leakage on long-term survival of patients undergoing curative } \\
\text { resection for colorectal cancer }\end{array}$ \\
\hline Breukink & 2005 & Laparoscopic versus open total mesorectal excision: a case-control study \\
\hline Patriti & 2005 & One-stage resection without colonic lavage in emergency surgery of the left colon \\
\hline Bucher & 2005 & $\begin{array}{l}\text { Randomized clinical trial of mechanical bowel preparation versus no preparation before } \\
\text { elective left-sided colorectal surgery }\end{array}$ \\
\hline Platell & 2005 & Clinical utility of a de-functioning loop ileostomy \\
\hline Resegotti & 2005 & $\begin{array}{l}\text { Side-to-Side Stapled Anastomosis Strongly Reduces Anastomotic Leak Rates in Crohn's } \\
\text { Disease Surgery }\end{array}$ \\
\hline Peeters & 2005 & Risk factors for anastomotic failure after total mesorectal excision of rectal cancer \\
\hline Stumpf & 2005 & $\begin{array}{l}\text { Changes of the extracellular matrix as a risk factor for anastomotic leakage after large } \\
\text { bowel surgery }\end{array}$ \\
\hline Eriksen & 2005 & $\begin{array}{l}\text { Anastomotic leakage following routine mesorectal excision for rectal cancer in a } \\
\text { national cohort of patients }\end{array}$ \\
\hline Yeh & 2005 & $\begin{array}{l}\text { Pelvic drainage and other risk factors for leakage after elective anterior resection in } \\
\text { rectal cancer patients: a prospective study of } 978 \text { patients }\end{array}$ \\
\hline Rudinskaite & 2005 & $\begin{array}{l}\text { risk factors for clinical anastomotic leakage following the resection of sigmoid and rectal } \\
\text { cancer }\end{array}$ \\
\hline Matthiessen & 2004 & Risk factors for anastomotic leakage after anterior resection of the rectum \\
\hline Kanellos & 2004 & Anastomotic leakage following anterior resection for rectal cancer \\
\hline Kanellos & 2004 & The failed intraperitoneal colon anastomosis after colon resection \\
\hline Raveenthiran & 2004 & Restorative resection of unprepared left-colon in gangrenous vs. viable sigmoid volvulus \\
\hline Schwandner & 2004 & $\begin{array}{l}\text { Laparoscopic colectomy for recurrent and complicated diverticulitis:a prospective study } \\
\text { of } 396 \text { patients }\end{array}$ \\
\hline Eckmann & 2004 & $\begin{array}{l}\text { Anastomotic leakage following low anterior resection: results of a standardized } \\
\text { diagnostic and therapeutic approach }\end{array}$ \\
\hline Leroy & 2004 & Laparoscopic total mesorectal excision (TME) for rectal cancer surgery \\
\hline
\end{tabular}


Table S3.2 (continued)

\begin{tabular}{|c|c|c|}
\hline Author & Year & Title \\
\hline $\begin{array}{l}\text { Garcia- } \\
\text { Botello }\end{array}$ & 2004 & A Prospective Audit of the Complications of Loop Ileostomy Construction and Takedown \\
\hline Walker & 2004 & $\begin{array}{l}\text { Anastomotic leakage is predictive of diminished survival after potentially curative } \\
\text { resection for colorectal }\end{array}$ \\
\hline Law & 2004 & $\begin{array}{l}\text { Anterior resection for rectal cancer with mesorectal excision: a prospective evaluation } \\
\text { of } 622 \text { patients }\end{array}$ \\
\hline Bell & 2003 & $\begin{array}{l}\text { Anastomotic leakage after curative anterior resection results in a higher prevalence of } \\
\text { local recurrence. }\end{array}$ \\
\hline Makela & 2003 & $\begin{array}{l}\text { Risk factors for anastomotic leakage after left-sided colorectal resection with rectal } \\
\text { anastomosis }\end{array}$ \\
\hline Schmidt & 2003 & $\begin{array}{l}\text { Anastomotic leakage after low rectal stapler anastomosis: significance of intraoperative } \\
\text { anastomotic testing }\end{array}$ \\
\hline Zmora & 2003 & $\begin{array}{l}\text { Colon and rectal surgery without mechanical bowel preparation: a randomized } \\
\text { prospective trial. }\end{array}$ \\
\hline Bertram & 2003 & $\begin{array}{l}\text { Peritoneal release of TNFalpha and IL-6 after elective colorectal surgery and } \\
\text { anastomotic leakage }\end{array}$ \\
\hline Killingback & 2002 & $\begin{array}{l}\text { Elective resection and anastomosis for colorectal cancer: a prospective audit of } \\
\text { mortality and morbidity 1976-1998 }\end{array}$ \\
\hline Marusch & 2002 & Value of a protective stoma in low anterior resections for rectal cancer \\
\hline Kuzu & 2002 & Emergent resection for acute sigmoid volvulus: results of 106 consecutive cases \\
\hline Leester & 2002 & Septic complications after low anterior rectal resection--is diverting stoma still justified? \\
\hline Z'graggen & 2001 & $\begin{array}{l}\text { A new surgical concept for rectal replacement after low anterior resection: the } \\
\text { transverse coloplasty pouch. }\end{array}$ \\
\hline Read & 2001 & $\begin{array}{l}\text { Neoadjuvant external beam radiation and proctectomy for adenocarcinoma of the } \\
\text { rectum. }\end{array}$ \\
\hline Tang & 2001 & $\begin{array}{l}\text { Risk factors for surgical site infection after elective resection of the colon and rectum: a } \\
\text { single-center prospective study of } 2,809 \text { consecutive patients. }\end{array}$ \\
\hline Brown & 2001 & A prospective randomised study of drains in infra-peritoneal rectal anastomoses. \\
\hline Hartley & 2001 & \\
\hline Poulin & 2001 & Septic complications of elective laparoscopic colorectal resection \\
\hline Tocchi & 2000 & Prospective evaluation of omentoplasty in preventing leakage of colorectal anastomosis \\
\hline Dehni & 1998 & $\begin{array}{l}\text { Influence of a defunctioning stoma on leakage rates after low colorectal anastomosis } \\
\text { and colonic J pouch-anal anastomosis }\end{array}$ \\
\hline Breen & 1998 & Functional results after perineal complications of ileal pouch-anal anastomosis \\
\hline Merad & 1998 & $\begin{array}{l}\text { Omentoplasty in the prevention of anastomotic leakage after colonic or rectal resection: } \\
\text { a prospective randomized study in } 712 \text { patients. French Associations for Surgical } \\
\text { Research }\end{array}$ \\
\hline Petersen & 1998 & $\begin{array}{l}\text { Anastomotic leakage: impact on local recurrence and survival in surgery of colorectal } \\
\text { cancer }\end{array}$ \\
\hline Mella & 1997 & $\begin{array}{l}\text { Population-based audit of colorectal cancer management in two UK health regions. } \\
\text { Colorectal Cancer Working Group, Royal College of Surgeons of England Clinical } \\
\text { Epidemiology and Audit Unit }\end{array}$ \\
\hline Vignali & 1997 & $\begin{array}{l}\text { Factors associated with the occurrence of leaks in stapled rectal anastomoses: a review } \\
\text { of } 1,014 \text { patients }\end{array}$ \\
\hline Moore & 1996 & $\begin{array}{l}\text { Morbidity and mortality after single- and double-stapled colorectal anastomoses in } \\
\text { patients with carcinoma of the rectum }\end{array}$ \\
\hline Hansen & 1996 & Colorectal stapled anastomoses. Experiences and results \\
\hline Hallbook & 1996 & Anastomotic leakage and functional outcome after anterior resection of the rectum \\
\hline
\end{tabular}


Table S3.2 (continued)

\begin{tabular}{|c|c|c|}
\hline Author & Year & Title \\
\hline Bokey & 1995 & $\begin{array}{l}\text { Postoperative morbidity and mortality following resection of the colon and rectum for } \\
\text { cancer }\end{array}$ \\
\hline Kessler & 1993 & $\begin{array}{l}\text { Operative mortality in carcinoma of the rectum. Results of the German Multicentre } \\
\text { Study }\end{array}$ \\
\hline Akyol & 1992 & $\begin{array}{l}\text { Early postoperative contrast radiology in the assessment of colorectal anastomotic } \\
\text { integrity }\end{array}$ \\
\hline Akyol & 1991 & Anastomotic leaks in colorectal cancer surgery: a risk factor for recurrence? \\
\hline Galandiuk & 1991 & $\begin{array}{l}\text { Postoperative irrigation-suction drainage after pelvic colonic surgery. A prospective } \\
\text { randomized trial }\end{array}$ \\
\hline Tuson & 1990 & A retrospective study of colostomies, leaks and strictures after colorectal anastomosis \\
\hline Cornwell & 1998 & The Fate of Colonic Suture Lines in High-Risk Trauma Patients: A Prospective Analysis \\
\hline Docherty & 1995 & ComparisonofManuallyConstructed andStapledAnastomosesin ColorectalSurgery \\
\hline Fingerhut & 1995 & $\begin{array}{l}\text { Supraperitoneal colorectal anastomosis: hand-sewn versus circular staples - a controlled } \\
\text { clinical trial }\end{array}$ \\
\hline Kracht & 1993 & $\begin{array}{l}\text { Ileocolonic anastomosis after right hemicolectomy for carcinoma: stapled or hand- } \\
\text { sewn? }\end{array}$ \\
\hline Miller & 1996 & Early Detection of Anastomotic Leaks After Low Anterior Resection of the rectum \\
\hline
\end{tabular}





\section{Part II}

Developing a predictive algorithm for anastomotic leakage 



\section{Chapter 4}

Predictive factors for anastomotic leakage after colorectal surgery: study protocol for a prospective observational study (REVEAL Study)

Audrey CHM Jongen, Joanna WAM Bosmans, Serdar Kartal, Tim Lubbers, Meindert Sosef, Gerrit D Slooter, Jan H Stoot, Frederik-Jan van Schooten, Nicole D Bouvy, Joep PM Derikx JMIR Res Protoc. 2016; 5(2): e90 


\section{Abstract}

\section{Background}

Anastomotic leakage $(\mathrm{AL})$ remains the most important complication following colorectal surgery, and is associated with high morbidity and mortality rates. Previous research has focused on identifying risk factors and potential biomarkers for $A L$, but the sensitivity of these tests remains poor.

Objective

This prospective multicenter observational study aims at combining multiple parameters to establish a diagnostic algorithm for colorectal AL.

\section{Methods}

This study aims to include 588 patients undergoing surgery for colorectal carcinoma. Patients will be eligible for inclusion when surgery includes the construction of a colorectal anastomosis. Patient characteristics will be collected upon consented inclusion, and buccal swabs, breath, stool, and blood samples will be obtained prior to surgery. These samples will allow for the collection of information regarding patients' inflammatory status, genetic predisposition, and intestinal microbiota. Additionally, breath and blood samples will be taken postoperatively and patients will be strictly observed during their in-hospital stay, and the period shortly thereafter.

Results

This study has been open for inclusion since August 2015.

\section{Conclusions}

An estimated $8-10 \%$ of patients will develop AL following surgery, and they will be compared to non-leakage patients. The objectives of this study are twofold. The primary aim is to establish and validate a diagnostic algorithm for the pre-operative prediction of the risk of $\mathrm{AL}$ development using a combination of inflammatory, immune-related, and genetic parameters. Previously established risk factors and novel parameters will be incorporated into this algorithm, which will aid in the recognition of patients who are at risk for AL. Based on these results, recommendations can be made regarding the construction of an anastomosis or deviating stoma, and possible preventive strategies. Furthermore, we aim to develop a new algorithm for the post-operative diagnosis of AL at an earlier stage, which will positively reflect on short-term survival rates. 


\section{Introduction}

Surgery remains the predominant curative treatment for patients with colorectal cancer (CRC), but can lead to severe post-operative complications, of which anastomotic leakage $(A L)$ is the most feared. $A L$ occurs in $8-15 \%$ of patients undergoing colorectal surgery and is associated with high morbidity and short-term mortality rates of up to $39 \%^{1-4}$. AL often requires one or more re-interventions, leading to a significant increase in length of hospital stay and subsequently to high health care costs ${ }^{3}$. Some authors even suggest that $A L$ is associated with an impaired oncological prognosis ${ }^{5-8}$. Both

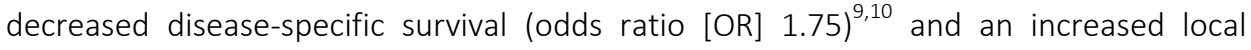
recurrence rate of CRC (OR 2.9) ${ }^{10}$ have been reported.

In the past decades, important risk factors for AL such as male gender ${ }^{4}$, neo-adjuvant chemotherapy $^{11}$, tumour size ${ }^{12}$, malnutrition ${ }^{13}$, smoking ${ }^{14}$, steroid treatment ${ }^{1,15}$, and the use of non-steroidal anti-inflammatory drugs (NSAIDs) ${ }^{16}$ have been identified. Despite the determination of these risk factors for $\mathrm{AL}$, surgeons' prediction of the risk to develop $A L$ for the individual patient remains inaccurate ${ }^{17}$. Despite decades of extensive research on preventive methods, the introduction of innovative surgical techniques, and fasttrack protocols, incidence rates of $\mathrm{AL}$ have remained stable ${ }^{18}$.

A recently conducted study in one of the participating centres, that can be considered a pilot study, suggests that pre-operative levels of a certain plasma marker (intestinal fatty acid binding protein, I-FABP) can predict the development of $A L$ in patients undergoing CRC surgery. I-FABP is present in mature enterocytes of the small and large intestine, and is released upon intestinal damage ${ }^{19}$. It is hypothesized that increased plasma levels of I-FABP are the result of an underlying clinical condition of the gastrointestinal tract, predisposing the patient to $\mathrm{AL}^{20}$.

Cumulative evidence in the literature suggests that perioperative pain treatment with NSAIDs, commonly prescribed analgesics that inhibit cyclo-oxygenase 2 (COX-2) expression, increase the risk of $A L^{16,21,22}$. COX-2 knockout mice have an increased risk of developing $\mathrm{AL}$, and this risk can be reduced by the administration of prostaglandin $\mathrm{E} 2$, a product of $\mathrm{COX}-2^{23}$. Another study conducted by our research group has demonstrated that decreased COX-2 expression, due to a polymorphism in the COX-2 gene, leads to an increased risk of the development of $\mathrm{AL}^{23}$. Furthermore, it has been shown that patients with different genotypes of mannose-binding lectin (MBL), an important complement factor of the immune system, respond differently to intestinal damage ${ }^{24}$. 
In the pilot study mentioned previously, it was shown that a combination of C-reactive protein (CRP) and calprotectin levels in plasma provides high diagnostic accuracy for $\mathrm{AL}$ during the post-operative period. Finally, we have shown that functional compromise (characterized by malnutrition, frailty, and sarcopenia) is associated with post-operative morbidity and mortality ${ }^{25}$. Malnutrition, as indicated by high Short Nutritional Assessment Questionnaire (SNAQ) scores, and sarcopenia were predictive for, or showed a trend towards, prediction of AL.

Based on previous literature and both our experimental and clinical data, we hypothesize that the occurrence of $A L$ is partly due to patient-derived factors such as a compromised immune response, sarcopenia, genetic predisposition, and an aberrant intestinal microbiome composition, and that the post-operative course can be further influenced by surgical stress, ischemia, and a derailed systemic response. Our hypothesis is that, based on these parameters, individual risks for the development of AL can be assessed pre-operatively.

Besides the obvious improvements that can be made regarding pre-operative risk assessment, the post-operative recognition and management of $A L$ has also proven to be challenging. The timing of AL diagnoses varies greatly, from post-operative day 3 to beyond 30 days, with a mean of 12.7 days post-operatively ${ }^{26}$. Abnormal vital signs and biochemical tests are quite common following the construction of a colorectal anastomosis, and can therefore not be used adequately in the diagnosis of AL. The presentation of AL can vary from abdominal pain and low-grade fever to peritonitis and severe sepsis. This nonspecific course of $A L$ often delays radiologic imaging, and even if this test is undertaken, the diagnoses frequently remain uncertain. Previous research has presented false-negative rates varying from $17-52 \%$ for both contrast enemas and computerized tomography (CT) scans $^{27}$, resulting in a significant delay of reintervention $^{28}$.

Since a delayed diagnosis of $\mathrm{AL}$ is associated with poor outcome ${ }^{29}$ and premature reintervention could lead to a high number of negative re-explorations, one should outweigh the risks of a delayed intervention and the morbidity of re-intervention. Physicians are armed with a restricted number of parameters contributing to risk analysis for the development of $A L$, with only limited specificity and sensitivity. 


\section{Study objectives}

The objectives of the Predictive Factors of Anastomotic Leakage after Colorectal Surgery (REVEAL) study are twofold. The primary aim of this study is to establish a risk assessment tool for the pre-operative prediction of the development of AL based on a combination of inflammatory, immune-related, and genetic parameters. This algorithm should enable surgeons to make an adequate estimation for every individual patient's risk of $\mathrm{AL}$, and will eventually aid in the decision-making process regarding the construction of anastomoses and deviating ostomies. In addition, this study aims to provide additional post-operative biomarkers for $\mathrm{AL}$ diagnosis at earlier stages, thereby reducing the clinical impact of this feared complication.

\section{Methods}

This is a study protocol for a multicenter, prospective observational study. This study is approved by the Medical Ethical Committee of the Maastricht University Medical Centre. A written informed consent is required from all participating patients and the trial will be conducted in compliance with the rules of Good Clinical Practice.

\section{Study population}

All patients aged $>18$ years undergoing elective colorectal surgery for colorectal carcinoma, with the construction of an anastomosis, in one of the three participating centres are eligible for inclusion. Patients with large adenomas (large tubular, tubulovillous, or sessile) that cannot be resected radically by means of endoscopy will be included as well, provided that the adenoma is removed surgically with the construction of a colorectal anastomosis. Sample size analysis revealed that 588 consecutive patients have to be included at the outpatient department, prior to surgery. Patients undergoing colorectal surgery for benign conditions, those with permanent stomata without anastomosis, or patients that are unable to give informed consent will be excluded from participation in this study, as well as pregnant patients. If no anastomosis is constructed during surgery, the patient will be withdrawn from the study. Eligibility for inclusion will be determined during a visit at the outpatient department. Upon approval, the patient will receive oral and written information regarding the study, after which he/she will have ample time to reconsider participation. Informed consent will be signed in the presence of the surgeon or researcher. 


\section{Participating centers}

This study will be conducted at Maastricht University Medical Centre (MUMC+, Maastricht, The Netherlands), Zuyderland Medical Centre (Sittard-Geleen and Heerlen, The Netherlands), and Máxima Medical Centre (MMC, Veldhoven, The Netherlands).

\section{Study outline}

Patients will be admitted to the ward one day prior to surgery, and perioperative care will be performed according to Enhanced Recovery After Surgery guidelines for elective colonic surgery $^{30}$. Due to the compelling evidence regarding the detrimental effects of NSAIDs on intestinal wound healing, these drugs will not be administered in this patient population during the perioperative phase. Instead, adequate pain treatment will be provided by means of acetaminophen and opioids if necessary. A Data Safety Monitoring Board has been commissioned to evaluate the quality of data collection and monitor patient safety. A web-based system was constructed in order to facilitate the collection of standardized and coded patient data.

The primary end point of this study is post-operative $A L$, occurring during the first 30 days after surgery, either during hospital admission or following discharge. $A L$ is defined as a communication between the intra- and extra-luminal compartments, resulting from a defect in the integrity of the intestinal wall. Leakage from the suture or staple line from a neorectal reservoir, as well as an abscess near the anastomosis, are also considered leaks ${ }^{31}$. The impact of AL on clinical management is recorded, together with the presence of subclinical (radiological) leaks.

Upon hospital admission, a buccal swab will be performed in order to collect DNA to screen for MBL and COX-2 polymorphisms. In addition, composition of volatile organic compounds (VOCs) in exhaled air will be measured both pre- and post-operatively. Various metabolic processes produce markers that are released into the circulation and, upon passage through the pulmonary system, can be identified as volatile products in exhaled air. The occurrence of (chronic) inflammation and/or oxidative stress can result in the excretion of volatile compounds that generate unique VOC patterns ${ }^{32}$. Furthermore, several baseline characteristics will be acquired prior to surgery, and stool will be collected on three occasions (pre-operatively, post-operatively and at the outpatient department during a control visit) in which the intestinal microbiome can be identified. It has been suggested that the microbiota play an important role in the pathogenesis of $\mathrm{AL}^{33}$ and that the composition of the intestinal flora can be altered by surgical stress ${ }^{34}$. Plasma will be collected prior to surgery and on post-operative days 1 , 
3 , and 5 , in order to determine the concentration of markers for enterocyte damage (eg, I-FABP, citrullin, and calprotectin), transmural ischemia (e.g, smooth muscle protein 22), and general inflammation markers (eg, CRP and leukocyte count).

In addition, SNAQ and Malnutrition Universal Screening Tool scores are obtained to assess the nutritional status of the patient, and CT-images are analyzed for total skeletal muscle cross-sectional area in order to distinguish sarcopenic patients from those in good nutritional health ${ }^{25}$. Generalized atherosclerosis will be assessed using abdominal CT-scans, as this is a proposed risk factor for $\mathrm{AL}^{35,36}$. Finally, a tissue sample will be obtained from the resected specimen, on which conventional and immunohistochemistry staining will be performed.

\section{Statistical analyses}

The sample size is calculated with a power analysis and is aimed at our main study outcome, AL. From literature, we know that approximately $10 \%$ of all colorectal patients receiving an anastomosis will develop $\mathrm{AL}^{14,37}$. The aim of the study is to detect significant and clinically relevant differences between the $\mathrm{AL}$ group and the non-AL group. Therefore, we used data from a previous study undertaken by our group to determine sample size ${ }^{20}$. We chose our least significant finding, to avoid the study being underpowered. Based on an effect size of 0.41 (calculated with mean calprotectin levels and SD on day 1 ), with a power of 0.80 and a $95 \%$ confidence interval, the total sample size will be 560, of whom an estimated 51 patients will develop AL. Assuming a 5\% dropout rate, the total number of patients that needs to be included in this study is 588 .

After data collection, normality will be tested by the D'Agostino-Pearson test. Student's t-tests will be used for between-group comparisons for continuous data. Dichotomous variables will be compared using Pearson's chi-squared test. All data will be presented as mean and standard error of the mean. The area under the curve of receiver operating characteristic (ROC) curves will be used to calculate the diagnostic ability of the studied markers predicting AL. The area under the ROC curve is a summary measure of accuracy, lying in the range from 0.5 to 1 , with 1 indicating perfect discrimination and 0.5 indicating no discrimination capacity. To determine the most ideal combination of markers, logistic regression analyses will be performed. 


\section{Results}

This study has been open for inclusion since August 2015.

\section{Discussion}

Despite important improvements in peri-operative care for CRC surgeries and increased awareness of $A L$, incidence rates of this dreaded complication have remained stable for several decades. Most strikingly, leakage continues to occur in patients treated under the most expert care, without the presence of any known risk factors ${ }^{38}$. The lack of knowledge regarding the pathophysiological process of $\mathrm{AL}$ and the process of normal intestinal healing hampers the development of novel predictive and preventive methods. AL has significant impacts on morbidity and mortality, quality of life, and health care costs, and is suggested to negatively interfere with oncological prognoses ${ }^{5-8}$. Although large numbers of clinical trials have identified important patient-related and technical factors that aid in the prediction of $\mathrm{AL}^{38,39}$, the search for a predictive biomarker for AL has hitherto remained unsuccessful. Almost all previously conducted studies reported a single risk factor for the development of AL in CRC patients undergoing surgery. The multi-modal design of the current study enables us to bypass the limitations encountered by previous studies.

In order to minimize the potentially life threatening clinical consequences of a leak, some surgeons opt to perform a deviating ostomy directly following the initial operation $^{41}$. Although it is generally accepted that the presence of a colostoma or ileostoma reduces the sequelae of $A L$ and the need for reoperation in case of a leak ${ }^{42,43}$, a decrease in incidence of post-operative mortality has not yet been proven ${ }^{42-46}$. The presence of selection bias, in which an ostomy is performed in high-risk patients, should be considered when interpreting these results. Surgeons perform elective deviating ostomy in approximately $70 \%$ of cases of low rectal carcinoma, of which a significant percentage (19-40\%) will never have their temporary ostomy reversed ${ }^{47,48}$. Possible benefits of a deviating stoma should be weighed against stoma-related morbidity, the impact on quality of life, and the mortality rates after stoma closure ${ }^{49,50}$. An adequate pre-operative risk analysis could aid surgeons and their patients in the decision-making process regarding the construction of temporary ostomies. The successful implementation of risk assessment tools would have a positive influence on morbidity and mortality rates, duration of hospital stays, and number of readmissions, reinterventions, and admissions to the ICU, leading to a significant increase in quality of life 
for the general patient population ${ }^{38}$. Anastomoses are also constructed in gastrointestinal surgery for other purposes than malignancies, such as inflammatory bowel disease or diverticulitis ${ }^{51,52}$. We have chosen to exclude these patients since their inflammatory status can be a confounding factor in the early detection and/or risk assessment of $\mathrm{AL}^{53-55}$.

This study outline is based on the hypothesis that AL is partly due to patient-derived factors such as a derailed immune response, genetic predisposition, and a deficient microbiome composition, and that the clinical course can be further influenced by surgical stress, ischemia, and a compromised systemic response. This study aims at broadening our understanding of the pathophysiological process of AL by introducing novel biomarkers of intestinal damage and function, and to decrease the clinical burden of $\mathrm{AL}$ by both individual pre-operative risk assessment and early post-operative detection in the future. 


\section{References}

1. Bertelsen CA, Andreasen AH, Jorgensen T, Harling H, Danish Colorectal Cancer G. Anastomotic leakage after curative anterior resection for rectal cancer: short and long-term outcome. Colorectal Dis 2010;12(7 Online):e76-81.

2. McArdle CS, McMillan DC, Hole DJ. Impact of anastomotic leakage on long-term survival of patients undergoing curative resection for colorectal cancer. Br J Surg 2005;92(9):1150-4. d

3. Alves A, Panis Y, Trancart D, Regimbeau JM, Pocard M, Valleur P. Factors associated with clinically significant anastomotic leakage after large bowel resection: multivariate analysis of 707 patients. World J Surg 2002;26(4):499-502.

4. Lipska MA, Bissett IP, Parry BR, Merrie AE. Anastomotic leakage after lower gastrointestinal anastomosis: men are at a higher risk. ANZ J Surg 2006;76(7):579-85.

5. Branagan G, Finnis D, Wessex Colorectal Cancer Audit Working G. Prognosis after anastomotic leakage in colorectal surgery. Dis Colon Rectum 2005;48(5):1021-6.

6. Walker KG, Bell SW, Rickard MJ, Mehanna D, Dent OF, Chapuis PH, et al. Anastomotic leakage is predictive of diminished survival after potentially curative resection for colorectal cancer. Ann Surg 2004;240(2):255-9.

7. Law WL, Choi HK, Lee YM, Ho JW, Seto CL. Anastomotic leakage is associated with poor long-term outcome in patients after curative colorectal resection for malignancy. J Gastrointest Surg 2007;11(1): 8-15.

8. Bell SW, Walker KG, Rickard MJ, Sinclair G, Dent OF, Chapuis PH et al. Anastomotic leakage after curative anterior resection results in a higher prevalence of local recurrence. Br J Surg 2003;90(10):1261-6.

9. Kulu Y, Tarantio I, Warschkow R, Kny S, Schneider M, Schmied BM et al. Anastomotic leakage is associated with impaired overall and disease-free survival after curative rectal cancer resection: a propensity score analysis. Ann Surg Oncol 2015;22(6):2059-67.

10. Mirnezami A, Mirnezami R, Chandrakumaran K, Sasapu K, Sagar P, Finan P. Increased local recurrence and reduced survival from colorectal cancer following anastomotic leak: systematic review and metaanalysis. Ann Surg 2011;253(5):890-9.

11. Pommergaard HC, Gessler B, Burcharth J, Angenete E, Haglind E, Rosenberg J. Preoperative risk factors for anastomotic leakage after resection for colorectal cancer: a systematic review and meta-analysis. Colorectal Dis 2014;16(9):662-71.

12. Eberl T, Jagoditsch M, Klingler A, Tschmelitsch J. Risk factors for anastomotic leakage after resection for rectal cancer. Am J Surg 2008;196(4):592-8.

13. Kang CY, Halabi WJ, Chaudhry OO, Nguyen V, Pigazzi A, Carmichael JC, et al. Risk factors for anastomotic leakage after anterior resection for rectal cancer. JAMA Surg 2013;148(1):65-71.

14. Bertelsen $\mathrm{CA}$, Andreasen $\mathrm{AH}$, Jorgensen $\mathrm{T}$, Harling $\mathrm{H}$. Anastomotic leakage after anterior resection for rectal cancer: risk factors. Colorectal Dis 2010;12(1):37-43.

15. Slieker JC, Komen N, Mannaerts GH, Karsten TM, Willemsen P, Murawska M, et al. Long-term and perioperative corticosteroids in anastomotic leakage: a prospective study of 259 left-sided colorectal anastomoses. Arch Surg 2012;147(5):447-52.

16. Hakkarainen TW, Steele SR, Bastaworous A, Dellinger EP, Farrokhi E, Farjah F, et al. Nonsteroidal antiinflammatory drugs and the risk for anastomotic failure: a report from Washington State's Surgical Care and Outcomes Assessment Program (SCOAP). JAMA Surg 2015;150(3):223-8.

17. Karliczek A, Harlaar NJ, Zeebregts CJ, Wiggers T, Baas PC, van Dam GM. Surgeons lack predictive accuracy for anastomotic leakage in gastrointestinal surgery. Int J Colorectal Dis 2009;24(5):569-76.

18. Paun BC, Cassie S, MacLean AR, Dixon E, Buie WD. Postoperative complications following surgery for rectal cancer. Ann Surg 2010;251(5):807-18.

19. Schellekens DH, Grootjans J, Dello SA, van Bijnen AA, van Dam RM, Dejong CH et al. Plasma intestinal fatty acid-binding protein levels correlate with morphologic epithelial intestinal damage in a human translational ischemia-reperfusion model. J Clin Gastroenterol 2014;48(3):253-60. 
20. Reisinger KW, Poeze M, Hulsewe KW, van Acker BA, van Bijnen AA, Hoofwijk AG, et al. Accurate prediction of anastomotic leakage after colorectal surgery using plasma markers for intestinal damage and inflammation. J Am Coll Surg 2014;219(4):744-51.

21. Rushfeldt CF, Sveinbjornsson B, Soreide K, Vonen B. Risk of anastomotic leakage with use of NSAIDs after gastrointestinal surgery. Int J Colorectal Dis 2011;26(12):1501-9.

22. Subendran J, Siddiqui N, Victor JC, McLeod RS, Govindarajan A. NSAID use and anastomotic leaks following elective colorectal surgery: a matched case-control study. J Gastrointest Surg 2014;18(8): 1391-7.

23. Matthijsen RA, Derikx JP, Steffensen R, van Dam RM, Dejong CH, Buurman WA. Mannose-binding lectin null alleles are associated with preserved epithelial cell integrity following intestinal ischemia reperfusion in man. Mol Immunol 2009;46(11-12):2244-8.

24. Reisinger KW, van Vugt JL, Tegels JJ, Snijders C, Hulsewe KW, Hoofwijk AG, et al. Functional compromise reflected by sarcopenia, frailty, and nutritional depletion predicts adverse postoperative outcome after colorectal cancer surgery. Ann Surg 2015;261(2):345-52..

25. Hyman N, Manchester TL, Osler T, Burns B, Cataldo PA. Anastomotic leaks after intestinal anastomosis: it's later than you think. Ann Surg 2007;245(2):254-8..

26. Doeksen A, Tanis PJ, Wust AF, Vrouenraets BC, van Lanschot JJ, van Tets WF. Radiological evaluation of colorectal anastomoses. Int J Colorectal Dis 2008;23(9):863-8.

27. Doeksen A, Tanis PJ, Vrouenraets BC, Lanschot van JJ, Tets van WF. Factors determining delay in relaparotomy for anastomotic leakage after colorectal resection. World J Gastroenterol 2007;13(27): 3721-5.

28. Alves A, Panis Y, Pocard M, Regimbeau JM, Valleur P. Management of anastomotic leakage after nondiverted large bowel resection. J Am Coll Surg 1999;189(6):554-9.

29. Gustafsson UO, Scott MJ, Schwenk W, Demartines N, Roulin D, Francis N, et al. Guidelines for perioperative care in elective colonic surgery: Enhanced Recovery After Surgery (ERAS(R)) Society recommendations. Clin Nutr 2012;31(6):783-800.

30. Rahbari NN, Weitz J, Hohenberger W, Heald RJ, Moran B, Ulrich A et al. Definition and grading of anastomotic leakage following anterior resection of the rectum: a proposal by the International Study Group of Rectal Cancer. Surgery 2010;147(3):339-51.

31. Boots AW, van Berkel JJ, Dallinga JW, Smolinska A, Wouters EF, van Schooten FJ. The versatile use of exhaled volatile organic compounds in human health and disease. J Breath Res 2012;6(2):027108.

32. Shogan BD, Belogortseva N, Luong PM, Zaborin A, Lax S, Bethel C et al. Collagen degradation and MMP9 activation by Enterococcus faecalis contribute to intestinal anastomotic leak. Sci Transl Med 2015; 7(286):286ra68.

33. Shogan BD, Smith DP, Christley S, Gilbert JA, Zaborina O, Alverdy JC. Intestinal anastomotic injury alters spatially defined microbiome composition and function. Microbiome 2014;2:35.

34. Komen N, Klitsie P, Dijk JW, Slieker J, Hermans J, Havenga K et al. Calcium score: a new risk factor for colorectal anastomotic leakage. Am J Surg 2011;201(6):759-65.

35. Foster ME, Brennan SS, Morgan A, Leaper DJ. Colonic ischaemia and anastomotic healing. Eur Surg Res $1985 ; 17(3): 133-9$.

36. Krarup PM, Jorgensen LN, Andreasen AH, Harling $\mathrm{H}$. A nationwide study on anastomotic leakage after colonic cancer surgery. Colorectal Dis 2012;14(10):e661-7.

37. Bertelsen CA, Andreasen AH, Jorgensen T, Harling H, Danish Colorectal Cancer G. Anastomotic leakage after anterior resection for rectal cancer: risk factors. Colorectal Dis 2010;12(1):37-43.

38. Bellows CF, Webber LS, Albo D, Awad S, Berger DH. Early predictors of anastomotic leaks after colectomy. Techn Coloproctol 2009;13(1):41-7.

39. Alberts JC, Parvaiz A, Moran BJ. Predicting risk and diminishing the consequences of anastomotic dehiscence following rectal resection. Colorectal Dis 2003;5(5):478/82.

40. Boccola MA, Buettner PG, Rozen WM, Siu SK, Stevenson AR, Stitz R et al. Risk factors and outcomes for anastomotic leakage in colorectal surgery: a single-institution analysis of 1576 patients. World J Surg 2011;35(1):186-95.

41. Shogan BD, Carlisle EM, Alverdy JC, Umanskiy K. Do we really know why colorectal anastomoses leak? J Gastrointest Surg 2013;17(9):1698-707. 
42. Matthiessen P, Hallbook O, Rutegard J, Simert G, Sjodahl R. Defunctioning stoma reduces symptomatic anastomotic leakage after low anterior resection of the rectum for cancer: a randomized multicenter trial. Ann Surg 2007;246(2):207-14.

43. Gastinger I, Marusch F, Steinert R, Wolff S, Koeckerling F, Lippert H, et al. Protective defunctioning stoma in low anterior resection for rectal carcinoma. Br J Surg 2005;92(9):1137-42.

44. Hanna MH, Vinci A, Pigazzi A. Diverting ileostomy in colorectal surgery: when is it necessary? Langenbecks Arch Surg 2015;400(2):145-52.

45. Anderin K, Gustafsson UO, Thorell A, Nygren J. The effect of diverting stoma on postoperative morbidity after low anterior resection for rectal cancer in patients treated within an ERAS program. Eur J Surg Oncol 2015;41(6):724-30.

46. Wong NY, Eu KW. A defunctioning ileostomy does not prevent clinical anastomotic leak after a low anterior resection: a prospective, comparative study. Dis Colon Rectum 2005;48(11):2076-9.

47. Mealy K, O'Broin E, Donohue J, Tanner A, Keane FB. Reversible colostomy--what is the outcome? Dis Colon Rectum 1996;39(11):1227-31.

48. Lim SW, Kim HJ, Kim CH, Huh JW, Kim YJ, Kim HR. Risk factors for permanent stoma after low anterior resection for rectal cancer. Langenbecks Arch Surg 2013;398(2):259-64.

49. Guenaga KF, Lustosa SA, Saad SS, Saconato H, Matos D. lleostomy or colostomy for temporary decompression of colorectal anastomosis. The Cochrane database of systematic reviews 2007(1): CD004647.

50. Mala T, Nesbakken A. Morbidity related to the use of a protective stoma in anterior resection for rectal cancer. Colorectal Dis 2008;10(8):785-8.

51. Bernstein CN, Fried M, Krabshuis JH, Cohen H, Eliakim R, Fedail S, et al. World Gastroenterology Organization Practice Guidelines for the diagnosis and management of IBD in 2010. Inflamm Bowel Dis 2010;16(1):112-24.

52. Janes SE, Meagher A, Frizelle FA. Management of diverticulitis. BMJ 2006;332(7536):271-5.

53. Sarikaya M, Ergul B, Dogan Z, Filik L, Can M, Arslan L. Intestinal fatty acid binding protein (I-FABP) as a promising test for Crohn's disease: a preliminary study. Clin Lab 2015;61(1-2):87-91.

54. Kurada S, Alkhouri N, Fiocchi C, Dweik R, Rieder F. Review article: breath analysis in inflammatory bowel diseases. Aliment Pharmacol Ther 2015;41(4):329-41.

55. Desai D, Faubion WA, Sandborn WJ. Review article: biological activity markers in inflammatory bowel disease. Aliment Pharmacol Ther 2007;25(3):247-55. 


\section{Chapter}

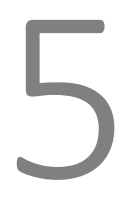

Near-infrared fluorescence imaging-guidance in anastomotic colorectal cancer surgery and its relation to serum markers of anastomotic leakage: a clinical pilot study

Jacqueline van den Bos, Audrey C.H.M. Jongen, Jarno Melenhorst, Stéphanie O. Breukink, Kaatje Lenaerts, Rutger M. Schols, Nicole D. Bouvy, Laurents P.S. Stassen

Surg Endosc. 2019 Feb. Epub ahead of print 


\section{Abstract}

Objective

Near-infrared fluorescence (NIRF) imaging using indocyanine green (ICG) might help reduce anastomotic leakage $(A L)$ after colorectal surgery. This pilot study aims to analyze whether a relation exists between measured fluorescence intensity (FI) and postoperative inflammatory markers of AL, C-reactive protein (CRP), Intestinal fatty-acid binding protein (I-FABP), and calprotectin, to $A L$, in order to evaluate the potential of $\mathrm{FI}$ to objectively predict AL.

\section{Methods}

Patients scheduled for anastomotic colorectal cancer surgery were eligible for inclusion in this prospective pilot study. During surgery, at three time points (after bowel devascularization; before actual transection; after completion of anastomosis) a bolus of $0.2 \mathrm{mg} / \mathrm{kg}$ ICG was administered intravenously for assessment of bowel perfusion. FI was scored in scale from 1 to 5 based on the operating surgeon's judgment (1=no fluorescence visible, $5=$ maximum fluorescent signal). The complete surgical procedure was digitally recorded. These recordings were used to measure $\mathrm{FI}$ postoperatively using OsiriX imaging software. Serum CRP, I-FABP, and calprotectin values were determined before surgery and on day 1,3 , and 5 postoperative; furthermore, the occurrence of $\mathrm{AL}$ was recorded.

Results

Thirty patients ( $n=19$ males; mean age 67 years; mean BMI 27.2) undergoing either laparoscopic or robotic anastomotic colorectal surgery were included. Indication for surgery was rectal- $(n=10)$, rectosigmoid- $(n=2)$, sigmoid- $(n=10)$, or more proximal colon carcinomas $(n=8)$. Five patients $(16.7 \%)$ developed $A L(n=2(6.6 \%)$ grade $C$ according to the definition of the International Study group of Rectal Cancer). In patients with $A L$, the maximum fluorescence score was given less often $(\mathrm{P}=0.02)$ and a lower $\mathrm{FI}$ compared to background $\mathrm{Fl}$ was measured at 1 st assessment $(\mathrm{P}=0.039)$. However, no relation between $\mathrm{Fl}$ and postoperative inflammatory parameters could be found.

Conclusion

Both subjective and measured $\mathrm{FI}$ seem to be related to AL. In this study, no relation between $\mathrm{Fl}$ and inflammatory serum markers could yet be found. 


\section{Introduction}

Anastomotic leakage $(\mathrm{AL})$ is the most feared complication in colorectal (cancer) surgery. The severity of leakage may vary from a contained peri-anastomotic fluid collection to generalized peritonitis. Furthermore, long-term morbidity including stricture formation, bowel dysfunction, and an increased chance of locoregional cancer recurrence has been described $^{1-3}$.

Clinically apparent anastomotic insufficiency occurs in 5.6-11.9\% of all colorectal resections ${ }^{4-6}$. As reported in literature, up to $32 \%$ of patients with $A L$ die because of this postoperative complication ${ }^{4}$. These numbers show the urgent need to prevent AL. Prevention starts with eliminating provoking factors. Decreased blood perfusion at the anastomosis is such a factor that contributes to anastomotic leakage ${ }^{7-9}$. Therefore, it is hypothesized that a better visualization of the vascularization of the anastomosis will aid in preventing anastomotic leaks.

Intra-operatively, the selection of an optimal site for anastomosis with adequate perfusion is now dependent on subjective clinical indicators such as colour of the bowel, bleeding of the resection margins, and palpable or visible pulsations of the mesenteric arterial vessels (i.e., the clinical judgement of the surgeon). Karliczek et al. ${ }^{8}$ discussed that there is a lack of a reliable intraoperative predictive test for AL by the operating surgeon.

Earlier studies used Doppler ultrasound and laser Doppler to assess colorectal anastomotic vascularization ${ }^{9}$. Peri-anastomotic tissue oxygenation has been evaluated, but has not been incorporated in routine practice due to the complexity and limited effectivity of the technique ${ }^{10}$. There is need for a technique that can accurately and consistently assess bowel perfusion at the anastomotic site in real time.

Near-infrared fluorescence (NIRF) imaging allows surgeons to visualize the microperfusion of the bowel in real time ${ }^{11}$. This technique, with perioperative indocyanine green (ICG) administration, has been shown feasible in assessing the vascularization of the bowel to be anastomosed. Fluorescence angiography with perioperative ICG administration seems to improve the outcome of laparoscopic anastomotic bowel surgery, in terms of safety and efficiency ${ }^{11,12}$. However, in studies confirming the lower incidence of $A L$, no objective quantification of the signal was performed ${ }^{1,2,7,13-15}$. Such quantification is desired to make the technique a reliable tool to accurately and consistently assess bowel perfusion at the anastomotic site in real time. 
C-reactive protein (CRP) is an early predictor of postoperative infection and has been shown to correlate with $\mathrm{AL}^{16-18}$. Intestinal fatty-acid binding protein (I-FABP) is a marker for enterocyte damage ${ }^{19,20}$. Earlier research showed a significant higher I-FABP at day 3 postoperatively in patients with $\mathrm{AL}^{21}$. In the same study, calprotectin levels were elevated on day 2 up to day 5 in patients with AL.

In this pilot study, we aim to analyze whether a relation exists between the objectively quantified signal of ICG fluorescence angiography during laparoscopic or robotic colorectal surgery and the levels of the serum markers related to anastomotic leakage: CRP, I-FABP, and calprotectin, in order to evaluate the potential of FI to objectively predict AL. To our knowledge, this is the first effort to assess the existence of such a correlation.

\section{Materials and methods}

All patients provided written informed consent. This study was approved by the Medical Ethical Committee of Maastricht University Medical Centre and conducted according to the Declaration of Helsinki (October 2013, Fortaleza). Included patients were part of the REVEAL study ${ }^{22}$, which is registered at clinicaltrials.gov (NCT02347735).

\section{Study subjects}

Colorectal cancer patients scheduled for either laparoscopic or robotic anastomotic surgery were eligible for inclusion. Patients with inflammatory bowel disease were excluded because this could influence plasma levels of the inflammatory markers. Additional exclusion criteria were known iodine or indocyanine green hypersensitivity, impaired renal function (eGFR<45), pregnancy or breast-feeding (all are contraindications for the use of ICG), and inability to give informed consent. None of the included patients used non-steroidal anti-inflammatory drugs (NSAIDs) or corticosteroids. Patient characteristics (sex, age, BMI, medical history, tumour location) and surgical characteristics (type of surgery, anastomotic technique, ostomy, operation time, conversion rate) were collected.

\section{Surgical technique}

The surgical procedures were performed by experienced laparoscopic colorectal surgeons and started as usual in white light. In laparoscopic cases, a system equipped with fluorescence imaging (Karl Storz GmbH \& CO. KG, Tuttlingen, Germany) with a 
xenon-based light source (D-light $P$ ) was used and in robotic surgeries, the da Vinci ${ }^{\circledR}$ System with Firefly fluorescence imaging (Surgical Intuitive, Sunnyvale, United States of America) was used. Surgery was performed as usual except for three time points, at which a bolus of $0.2 \mathrm{mg} / \mathrm{kg}$ ICG (Verdye; Diagnostic Green Aschheim, Germany) was administered. These three set time points were:

1. Directly after transection of all the vessels supplying the bowel segment to be resected (i.e., after devascularization of the segment).

2. Just before actual transection.

3. Directly after the anastomosis is made.

After each gift of ICG, the system was switched to NIRF mode and the surgeon was asked to rate the fluorescence intensity of the bowel both proximal and distal to the planned proximal transection line or stapler line on a scale from 1 to 5 . Herein, a score of 1 meant no fluorescent signal, while a score of 5 meant 'maximum fluorescent signal.' Also, the surgeon was asked whether he or she changed the location of transection based on the visualized fluorescent signal.

When proximal transection was performed extra-corporally, the operative room was completely darkened in order to capture the fluorescent signal with the respective imaging device.

\section{Fluorescence intensity measurement}

Postoperatively, the images of the bowel were assessed with OsiriX imaging software (Pixmeo, Geneva, Switzerland) to quantify the FI. This software measures the gray value in arbitrary units (AU). At the aforementioned three time points, the FI was measured approximately $1 \mathrm{~cm}$ proximal and $1 \mathrm{~cm}$ distal from the proximal transection point or anastomosis and of the background (abdominal wall or fat directly surrounding the relevant bowel part) in a screenshot taken approximately 1 min after ICG administration. In the right hemicolectomies, the distal transection point was used. In case of extracorporeal proximal transection, also three points in the direct surrounding of the bowel were measured as background. The target-to-background ratio (TBR) was defined as the mean $\mathrm{Fl}$ in arbitrary units (AU) of the bowel wall $1 \mathrm{~cm}$ proximal or distal from the planned proximal (or in right hemicolectomies distal) transection location or $1 \mathrm{~cm}$ from the staple line of the anastomosis minus the $\mathrm{FI}$ of the background divided by the mean $\mathrm{FI}$ in the background (abdominal wall or fat directly surrounding the relevant bowel part). 


\section{Definition anastomotic leakage}

The patients were followed up to 30 days after surgery, during which the occurrence of complications and especially AL was recorded. Clinically relevant AL was defined and classified according to the definition from the International Study group of Rectal Cancer

${ }^{23}$. In this definition, $\mathrm{AL}$ is a defect of the anastomotic wall integrity at the colorectal or colo-anal anastomotic site leading to a communication between the intra-and extraluminal compartments. A pelvic abscess close to the anastomosis is also considered AL. We applied this definition also to the included colocolic and ileocolic anastomoses in our study. A distinction is made between the severity of $A L$ based on the intervention required:

- Grade A: Anastomotic leakage requiring no active therapeutic intervention;

- Grade B: Anastomotic leakage requiring active therapeutic intervention but manageable without relaparotomy;

- Grade C: Anastomotic leakage requiring relaparotomy ${ }^{23}$.

\section{Analysis of inflammatory markers}

Venous blood was drawn at hospital admission (preoperative sample) and on day 1, 3, and 5 after surgery, unless the patient was discharged home earlier. C-reactive protein (CRP) plasma levels were determined by using Immunoturbidimetric assay for the in vitro quantitative determination of CRP in human serum and plasma (Roche diagnostics, Germany). Serum calprotectin concentration was determined using a commercially available calprotectin ELISA (Hycult Biotechnology, Uden, The Netherlands). Intestinal fatty-acid binding protein (I-FABP) plasma levels were determined using an in-house ELISA that selectively detects human I-FABP ${ }^{21}$.

\section{Statistical analysis}

Basic descriptive statistics were applied to calculate means and standard deviation of the baseline characteristics. Because of the small sample size, non-parametric tests were used to analyze the data retrieved in this study. To compare continuous variables between two groups, the Mann-Whitney test was performed. To compare categorical outcomes between two groups, a Pearson Chi-square crosstab was used. The relation between the measured fluorescence intensity and the values of the inflammatory markers was evaluated using a regression analysis. $P<0.05$ was considered to denote statistical significance. All statistical analyses were performed with SPSS version 23 (IBM, Armonk, NY, USA). 


\section{Results}

\section{Study population}

Thirty patients were included with a mean age of 67.2 (SD 8.2) years of whom 19 (63\%) were male. All underwent elective surgery for colorectal cancer, of which 10 (33.3\%) concerned sigmoid carcinoma, 10 (33.3\%) rectum carcinoma, 5 (16.7\%) colon carcinoma in the right hemi-colon, 3 (10\%) cecum carcinoma, and 2 (6.7\%) rectosigmoid carcinoma. Five patients were treated with concomitant chemoradiotherapy before surgery, 4 with only chemotherapy (CAPOX-bevacizumab), and 3 received only radiotherapy ( $5 \times 5$ Gy). A conversion to open surgery was needed in 7 patients in whom a laparoscopic procedure was started, due to unclear anatomy in obese patients. Further baseline characteristics and surgical characteristics are summarized in Table 5.1.

Table 5.1 Baseline characteristics and surgical characteristics.

\begin{tabular}{lcc}
\hline & $\mathrm{n}(\%)$ & Mean (SD) \\
\hline Male & $19(63.3)$ & $67.2(8.2)$ \\
Age, years & & $82(16.4)$ \\
Weight, kg & & $27.2(4.9)$ \\
BMI, kg/m & & \\
Smoking & $12(40)$ & $5(16.6)$ \\
Both preoperative chemo- and radiotherapy & $4(13)$ \\
Preoperative chemotherapy & $3(10)$ \\
Preoperative radiotherapy & & \\
Location of suspected tumor & $3(10)$ \\
Cecum & $5(16.7)$ \\
Right hemi colon & $10(33.3)$ \\
Sigmoid & $2(6.7)$ \\
Recto-sigmoid & $10(33.3)$ \\
Rectum & & \\
Type of surgery & $8(26.7)$ \\
Laparoscopic right hemicolectomy & $11(36.7)$ \\
Laparoscopic sigmoid resection & $4(13.3)$ \\
Laparoscopic low anterior resection & $7(23.3)$ \\
Robot-assisted low anterior resection & $11(36.7)$ \\
Deviating stoma & \\
Type of anastomosis & \\
Side-to-end & $16(53.3)$ \\
End-to-end & $9(30)$ \\
Side-to-side & $5(16.7)$ \\
Conversion to open surgery & $7(23.3)$ \\
\hline
\end{tabular}




\section{Near-infrared fluorescence imaging}

A bolus of $0.2 \mathrm{mg} / \mathrm{kg}$ ICG was administered intravenously. Thus, the total dose ranged between 10.3 and $21.8 \mathrm{mg}$ with a mean of $16.4 \mathrm{mg}$ (SD 3.3). NIRF imaging was aimed to be performed at three time points. In 19 patients, fluorescence imaging was achievable at all three time points. In 10 patients, the first time point was very close to the second time point; therefore in these patients only just before transection (second time point) and after completion of the anastomosis, the bowel was assessed using NIRF imaging, in order to prevent potential accumulation of the dye at the second time point. In two patients, the anastomosis was too low to visualize the NIRF signal. The time between the first and second time point was on average 68.6 min (range 9-201) and between the second and third time point on average 40 min (range 11-84).

\section{Intraoperative decision making based on fluorescence imaging}

In six patients, the dissection location was changed, based on the fluorescent signal. One of these patients developed AL; the remaining 5 patients did not.

\section{Anastomotic leakage (AL)}

In 5 patients (16\%), AL occurred. In 2 of these cases, only a small abscess around the anastomosis was seen on CT scan and could be treated non-surgically with intravenous administration of antibiotics and CT-guided drainage. These leakages were considered as grade B AL. In 1 patient, AL could be treated with an endo-sponge applied via endoscopy and was also considered as Grade B AL. The remaining 2 patients (6\% of the total study population) needed relaparotomy for $\mathrm{AL}$ treatment (grade C). All patients with $\mathrm{AL}$ underwent a low anterior resection of a rectum or rectosigmoid carcinoma. Two of the $\mathrm{AL}$ patients had undergone preoperative chemoradiotherapy: one preoperative radiotherapy and one preoperative chemotherapy. The remaining patient was not preoperatively treated with neoadjuvant radiotherapy or chemotherapy. There were no statistical differences in age at the time of surgery, preoperative chemotherapy, BMI, administered dose of ICG per bolus (mg), conversion to open surgery, type of anastomosis, TNM classification after surgery, and difficulty of surgery between the patients who developed $\mathrm{AL}$ and the patients who did not. There were significantly more smokers in the AL group ( $P=0.046)$. The postoperative hospital stay was on average 16 days (median 12 days) in the patients with $\mathrm{AL}$, which was significantly longer compared to the patients without this complication, who stayed on average 5 days ( $P=0.004)$. A deviating ileostomy had been constructed more often in the AL group. See Table 5.2 for an overview of these characteristics. 
Other postoperative complications were postoperative ileus in one patient, which resolved without further consequence. The two patients who needed relaparotomy due to anastomotic leakage both developed pneumonia after the second surgery, which was treated with antibiotics.

Table 5.2 Characteristics of patients with anastomotic leakage compared to those without.

\begin{tabular}{|c|c|c|c|}
\hline & No $A L(n=25)$ & $A L(n=5)$ & P-value \\
\hline Male $n$ & $15 / 25$ & $4 / 5$ & 0.397 \\
\hline Age, years (median (IQR)) & $65.5(11.5)$ & $65.0(17)$ & 0.787 \\
\hline $\mathrm{BMI}, \mathrm{kg} / \mathrm{m}^{2}$ (median (IQR)) & $28.3(5.27)$ & $24.4(14.1)$ & 0.627 \\
\hline Smoking n & $8 / 25$ & $4 / 5$ & $0.046^{*}$ \\
\hline Preoperative chemoradiation & $3 / 25$ & $2 / 5$ & 0.183 \\
\hline Preoperative chemotherapy & $3 / 25$ & $1 / 5$ & 0.538 \\
\hline Preoperative radiotherapy & $2 / 25$ & $1 / 5$ & 0.433 \\
\hline Indication for surgery & & & 0.058 \\
\hline Cecum carcinoma & 3 & 0 & \\
\hline Right hemi colon carcinoma & 5 & 0 & \\
\hline Sigmoid carcinoma & 10 & 0 & \\
\hline Rectosigmoid carcinoma & 1 & 1 & \\
\hline Rectum carcinoma & 6 & 4 & \\
\hline Type of surgery & & & 0.107 \\
\hline Laparoscopic right colectomy & 8 & 0 & \\
\hline Laparoscopic sigmoid resection & 10 & 1 & \\
\hline Laparoscopic low anterior resection & 2 & 2 & \\
\hline Robotic low anterior resection & 5 & 2 & \\
\hline Change of dissection place & $5 / 25$ & $1 / 5$ & 1.000 \\
\hline Ileostomy & $7 / 25$ & $4 / 5$ & $0.028^{*}$ \\
\hline \multicolumn{4}{|l|}{ Type of anastomosis } \\
\hline Side-to-end & 13 & 3 & \\
\hline Side-to-side & 9 & 0 & \\
\hline End-to-end & 3 & 2 & \\
\hline Conversion to open surgery & $6 / 25$ & $1 / 5$ & 0.847 \\
\hline Surgical time, minutes (median (IQR)) & $203.5(95)$ & $287.0(358)$ & 0.344 \\
\hline Postoperative hospital stay, days (median (IQR)) & $4(2.25)$ & $12(22)$ & $0.004^{*}$ \\
\hline
\end{tabular}

\section{Subjective fluorescence intensity (FI)}

The $\mathrm{Fl}$ was scored by the surgeon on a scale from 1 to 5 . In all cases, in all three assessments, this score ranged between 3 and 5 for the bowel proximal to the proximal transection site, or distal transection site in right hemicolectomies. In the second assessment, the subjective score given for the $\mathrm{Fl}$ was 4 in four of the anastomotic leakage cases. In one of the anastomotic leakage cases, a score of 5 was given; this was one of the cases in which only an abscess close to the anastomosis was present. In the patients who did not develop AL the maximum score of 5 was given in 16 cases (73\%), which was significantly more often compared to the $A L$ group $(P=0.02)$. 
In both the first and third assessment, no significant differences in subjective fluorescence intensity between the patients with and without anastomotic leakage were seen. See Table 5.3 for the given scores.

Table 5.3 Subjective fluorescence intensity (FI) scores and anastomotic leakage (AL).

\begin{tabular}{llccrc}
\hline & & Fl score 3 & Fl score 4 & Fl score 5 & $\begin{array}{c}\text { Total no of } \\
\text { patients assessed }\end{array}$ \\
\hline $1^{\text {st }}$ assessment & No AL & 1 & 5 & 10 & 16 \\
& AL & 0 & 1 & 3 & 4 \\
$2^{\text {nd }}$ assessment & No AL & 3 & 4 & 18 & 25 \\
\multirow{2}{*}{$3^{\text {rd }}$ assessment } & AL & 0 & 4 & 1 & 5 \\
& No AL & 2 & 11 & 11 & 24 \\
& AL & 1 & 1 & 2 & 4 \\
\hline
\end{tabular}

The fluorescence intensity on first and second assessment is scored on the distal side of the distal anastomosis in laparoscopic right hemicolectomies, whilst on the proximal site of the proximal anastomosis in all remaining procedures.

\section{Measured fluorescence intensity}

Next to subjective scoring by the surgeon, the FI of the bowel proximal and distal from the proximal transection or distal in right hemicolectomies and the background was measured by image quantification. As shown in Tables 5.4, 5.5, 5.6, and 5.7, the $\mathrm{FI}$ in patients without $\mathrm{AL}$ was higher at almost all measurements compared to the $\mathrm{FI}$ in patients who develop AL. This difference is however only statistically significant when we take the background into account and assess the bowel distal from the proximal anastomosis in the 1 st assessment $(P=0.039)$ (see Table 5.7).

Table 5.4 Fluorescence intensity (FI) bowel proximal from the proximal transection line and anastomotic leakage (AL) (distal from distal transection line in right hemicolectomies, thus side from the transection line that stays in the patient).

\begin{tabular}{lccc}
\hline & Median FI no AL & Median FI AL & P-value \\
\hline $1^{\text {st }}$ assessment & $38.8(61.2)$ & $34.2(28.7)$ & 0.494 \\
$2^{\text {nd }}$ assessment & $49.2(45.0)$ & $44.1(94.6)$ & 0.385 \\
$3^{\text {rd }}$ assessment & $86.5(54.8)$ & $99.5(68.1)$ & 0.336 \\
\hline
\end{tabular}

Median fluorescence intensity (interquartile range).

Table 5.5 Fluorescence intensity $(\mathrm{FI})$ bowel distal from the proximal transection-line and anastomotic leakage (AL) (proximal from the distal transection line in right hemicolectomies, thus side from the transection line that will be resected).

\begin{tabular}{lccc}
\hline & Median FI no AL & Median FI AL & P-value \\
\hline $1^{\text {st }}$ assessment & $31.7(23.7)$ & $36.7(27.1)$ & 0.064 \\
$2^{\text {nd }}$ assessment & $40.8(32.4)$ & $64.5(72.8)$ & 0.448 \\
$3^{\text {rd }}$ assessment & $59.9(37.6)$ & $55.9(30.5)$ & 0.952 \\
\hline
\end{tabular}

Median fluorescence intensity (interquartile range). 
Table 5.6 Target to background ratio (TBR) bowel proximal from the proximal transection line and anastomotic leakage ( $\mathrm{AL}$ ) (distal from distal transection line in right hemicolectomies, thus side from the transection line that stays in the patient).

\begin{tabular}{lccc}
\hline & Median TBR no AL & Median TBR AL & P-value \\
\hline $1^{\text {st }}$ assessment & $2.8(4.7)$ & $1.1(1.4)$ & 0.820 \\
$2^{\text {nd }}$ assessment & $2.2(13)$ & $0.5(2.1)$ & 0.229 \\
$3^{\text {rd }}$ assessment & $1.4(2.6)$ & $1.4(1.0)$ & 0.669 \\
\hline
\end{tabular}

Median fluorescence intensity (Interquartile range).

Table 5.7 Target to background ratio (TBR) bowel distal from the proximal transection line and anastomotic leakage (AL) (proximal from distal transection line in right hemicolectomies, thus the side from the transection line that will be resected).

\begin{tabular}{lccc}
\hline & Median TBR no AL & Median TBR AL & P-value \\
\hline $1^{\text {st }}$ assessment & $3.4(6.9)$ & $1.2(1.3)$ & 0.039 \\
$2^{\text {nd }}$ assessment & $2.6(13.5)$ & $1.8(4.0)$ & 0.482 \\
$3^{\text {rd }}$ assessment & $1.4(2.9)$ & $0.9(0.1)$ & 0.364 \\
\hline
\end{tabular}

Median fluorescence intensity (interquartile range).

\section{Inflammatory serum markers}

As shown in Table 5.8, CRP was significantly higher on postoperative day 5 in anastomotic leakage patients. As is shown in Table 8, all other measured markers do not show a statistical difference between the occurrence of anastomotic leakage and serum levels on day 1,3 , or 5 (Table 5.8).

Table 5.8 Serum markers anastomotic leakage versus no anastomotic leakage.

\begin{tabular}{|c|c|c|c|}
\hline & No anastomotic leakage & Anastomotic leakage & P-value \\
\hline \multicolumn{4}{|l|}{ Mean CRP } \\
\hline Pre-operative $(\mathrm{mg} / \mathrm{ml}) \pm \mathrm{SD}$ & $2.9 \pm 2.3$ & $2.1 \pm 0.9$ & 0.69 \\
\hline Postoperative day $1(\mathrm{mg} / \mathrm{ml}) \pm \mathrm{SD}$ & $87.4 \pm 35.8$ & $87.4 \pm 35.3$ & 0.90 \\
\hline Postoperative day $3(\mathrm{mg} / \mathrm{ml}) \pm \mathrm{SD}$ & $101.1 \pm 48.0$ & $183.6 \pm 123.5$ & 0.09 \\
\hline Postoperative day $5(\mathrm{mg} / \mathrm{ml}) \pm \mathrm{SD}$ & $48.5 \pm 24.66$ & $152.8 \pm 90.7$ & $0.01^{*}$ \\
\hline \multicolumn{4}{|l|}{ Mean Calprotectin } \\
\hline Preoperative $(\mathrm{ng} / \mathrm{ml}) \pm \mathrm{SD}$ & $822.9 \pm 765.4$ & $3451.6 \pm 3987.1$ & 0.41 \\
\hline Postoperative day $1(\mathrm{ng} / \mathrm{ml}) \pm \mathrm{SD}$ & $7587.3 \pm 17589.9$ & $7743.5 \pm 12026.8$ & 1.0 \\
\hline Postoperative day $3(\mathrm{ng} / \mathrm{ml}) \pm \mathrm{SD}$ & $2467.0 \pm 1430.3$ & $1683.3 \pm 1549.4$ & 0.15 \\
\hline Postoperative day $5(\mathrm{ng} / \mathrm{ml}) \pm \mathrm{SD}$ & $3326.7 \pm 2783.0$ & $2756.1 \pm 1974.3$ & 0.68 \\
\hline \multicolumn{4}{|l|}{ I-FABP } \\
\hline Preoperative $(\mathrm{pg} / \mathrm{ml}) \pm \mathrm{SD}$ & $805 \pm 376.6$ & $520.1 \pm 516.1$ & 0.16 \\
\hline Postoperative day $1(\mathrm{pg} / \mathrm{ml}) \pm \mathrm{SD}$ & $644.7 \pm 370.4$ & $383.2 \pm 160.4$ & 0.14 \\
\hline Postoperative day $3(\mathrm{pg} / \mathrm{ml}) \pm \mathrm{SD}$ & $574.8 \pm 431.4$ & $373.9 \pm 335.3$ & 0.31 \\
\hline Postoperative day $5(\mathrm{pg} / \mathrm{ml}) \pm \mathrm{SD}$ & $496.9 \pm 291.4$ & $143.0 \pm 49.6$ & 0.05 \\
\hline
\end{tabular}




\section{Fluorescence intensity in relation to inflammatory serum markers}

The relation between the respective serum markers CRP, Calprotectin and I-FABP, and the fluorescent signal was assessed using a regression analysis. For none of the serum markers on any time point, a significant relation could be found with the fluorescence both proximal and distal or measured as TBR, with one exception. At the third time point, after the anastomosis is made, a higher TBR of the distal part of the anastomosis was related to a lower serum calprotectin level on postoperative day $5(P=0.046)$.

\section{Discussion}

NIRF angiography with ICG is used more and more in colorectal surgery as this technique holds the potential to lower the risk for anastomotic leakage ${ }^{11}$. However, it is unknown when the bowel is fluorescent enough to actually predict optimal anastomotic healing. In this respect, a cut-off value is desirable. To come to such consensus, we first need to know whether a "more fluorescent bowel" actually is indicative for a lower risk for anastomotic leakage and accompanying lower postoperative inflammatory parameters. Therefore, we performed this clinical pilot study, in which we aimed to correlate the signal strength of fluorescence angiography with the occurrence of $A L$ and with the level of the serum markers that are thought to be predictive of $A L$ : CRP, calprotectin, and I-FABP. The fluorescence intensity was measured after administration of $0.02 \mathrm{mg} / \mathrm{kg}$ ICG intravenously at three time points. CRP, calprotectin and I-FABP were determined preoperatively and on day 1,3 , and 5 after surgery. Follow-up for anastomotic leakage was until 30 days postoperatively.

In the current study, 5 (16.7\%) patients developed AL. Three of these leakages were considered a grade $\mathrm{B}$ leakage, while the remaining two were grade $\mathrm{C}$ anastomotic leakages which needed relaparoscopy. The number of patients with $\mathrm{AL}$ is somewhat higher compared to the literature $(5.6-11.9 \%)^{4-6}$, and especially when compared to other studies in which NIRF angiography is used during colorectal surgery ${ }^{11}$. This could be explained by the fact that both grade $\mathrm{B}$ and grade $\mathrm{C}$ anastomotic leakage were taken into account in this study, while other studies may have only considered grade $C$ leakage only. In addition, $40 \%$ of patients smoked, which is a risk factor for developing $\mathrm{AL}^{4,24}$. Remarkably, preoperative radiotherapy, which is also a known risk for leakage was not identified as such in our study. The limited number of patients may have contributed to this discrepancy. 
In all cases, the subjective score for FI proximal from the (planned) proximal transection line or distal from distal transection line (in right hemicolectomies), ranged between 3 and 5 on a scale from 1 to 5 . For the bowel proximal from the transection line, the maximum score of 5 was given significantly more often in the patients that healed without a leak. This is in line with the study by Ris et al. ${ }^{2}$ in which the fluorescence score ranges from 'good,' 'average,' to 'bad.' In all patients, the fluorescence was scored 'good' by the surgeon and none of the patients developed AL. Other studies scored the fluorescence intensity as 'good enough' or 'not good enough' based on subjective score of the surgeon. In these studies, if the fluorescence intensity was considered not good enough, the dissection place was changed ${ }^{3,25-29}$. The anastomotic leakage rate in patients with changed dissection level was equal ${ }^{13,25-27,29}$ or higher ${ }^{28}$ compared to the patients in which no change was needed after NIRF imaging. A possible explanation for a higher leak rate after change of transection location may be the fact that a clearly insufficiently perfused bowel end may be indicator of a longer segment of moderate perfusion. This emphasizes the need for cut-off values for level of perfusion ${ }^{11}$. In the current study, revision of surgical plan based on the $\mathrm{Fl}$ of the bowel occurred in six patients. One of these developed AL. These numbers are too low to draw conclusions.

In the present study, the objectively measured FI was higher in the patients who did not develop AL. This difference was only significant when taking the background into account and expressing data as TBR. By using TBR, a correction is made for the distance between the endoscope and the bowel. A shorter distance between the laparoscope and the target causes a higher $\mathrm{Fl}^{30}$. By taking the background into account, this effect is minimized, since the background will also show increased fluorescence intensity when holding the laparoscope closer to the tissue. Such correction of the signal seems necessary, as in practice, it is not always possible to exactly measure and standardize the distance to the bowel.

According to literature, the CRP trajectory is highly predictive for $\mathrm{AL}^{6}$. In the current series, CRP on postoperative day 5 was significantly higher in patients who developed AL. This observation is in line with findings reported in literature. An earlier study by Reisinger et al. ${ }^{21}$ showed a rise in postoperative CRP in patients with an anastomotic leak, which was only significant on day 4 . Bigin et al. ${ }^{31}$ showed a significant higher CRP on postoperative day 3, but unfortunately CRP was not measured on postoperative day 5 . Reynolds et al. ${ }^{17}$ found a significantly higher CRP level in patients with grade C AL on day 5 up to day 7. Unfortunately, in the current study, no relation of CRP and subjective or measured fluorescence intensity or TBR could be found. 
Calprotectin is a non-specific marker for acute inflammation ${ }^{32}$. An earlier study by Reisinger et al. ${ }^{21}$ showed higher calprotectin levels on postoperative day 2, 3, 4, and 5 in patients who developed AL. Similar results were found by Cikot et al. ${ }^{33}$. In the current study however, no statistical difference in serum calprotectin levels could be found between patients with and without anastomotic leakage on postoperative day 1, 3, or 5 . Interestingly, serum calprotectin levels on postoperative day 5 were negatively correlated with TBR of the distal part of the anastomosis. This relation needs to be confirmed in a larger study to determine its clinical relevance.

I-FABP is an intestinal cell damage marker ${ }^{21}$. An earlier study by Reisinger et al. ${ }^{21}$ showed significantly higher I-FABP levels preoperatively in patients who developed anastomotic leakage. The I-FABP levels remained higher in these patients after surgery, but only statistically significant on postoperative day 3. In the current study however, I-FABP levels were lower at all time points in the patients who developed anastomotic leakage, although this difference was not significant. Moreover, we could not detect a significant relation between $\mathrm{FI}$ and serum I-FABP values in this study.

A possible explanation for this discrepancy might be the low specificity of I-FABP. This marker for enterocyte damage is not only elevated in case of inflammation, but also in patients with colorectal cancer compared to patients without colorectal cancer ${ }^{34}$. When only taking the patients with a grade $\mathrm{C}$ anastomotic leakage into account, a (nonstatistically significant) higher I-FABP value is found in the leakage patients. More research is needed to determine its place in the management of the colorectal operative patient.

Higher fluorescence intensity was found in all cases in the bowel at the side that will remain in the patients after surgery. This means that the devascularized bowel results in a lower signal, indicating that the fluorescent signal does reflect bowel perfusion.

This study has some limitations. First, it was designed as a pilot study to explore whether there is a potential relation between $\mathrm{Fl}$ and inflammatory serum markers that correspond with AL. A relatively small and heterogenous group of patients was included. With the markers and the patient group chosen here, it was not yet possible to identify a cut-off value of fluorescent signal that indicates an optimal anastomotic healing potential. A more homogenous patient group (e.g., only right hemicolectomies or rectal resections) might have given different results. Another factor of influence could be that only the measurements at single time points were performed, and not an evaluation of the signal intensity over time after administration of the respective boluses of ICG. The 
small number of included patients can be an explanation for finding few statistical significant differences for most outcome parameters.

In this study, several time points of ICG administration were chosen. Although arterially the dye washes out very quickly-which is evident when observed with the naked eyeit cannot be ruled out that some retention of the dye occurred. Although this phenomenon will take place in both the bowel wall and the background, this may have influenced the objective measurements. The time between the first and second dose administration was on average 68.6 min (range 9-201) and between the second and third bolus of ICG 40 min (range 11-84). A cut-off value for the optimal interval is not known in literature.

In conclusion, both subjective and measured FI seem to be related to the occurrence of AL. In this pilot study, no relation between $\mathrm{Fl}$ and inflammatory serum markers could yet be found nor a cut-off value of FI predicting AL. A larger study based on the current study, with a single time point of measurement in a homogenous population seems preferable to enhance the chance that an objective cut-off value of the fluorescent signal to predict AL will be identified. Ideally, future research identifies such cut-off value, but also leads to presenting the objective result of fluorescence measurement real time to the surgeon, thereby supplying the surgeon with essential per-operative information for the optimal transection point to prevent anastomotic leakage. 


\section{References}

1. Sherwinter DA, Gallagher J, Donkar T. Intra-operative transanal near infrared imaging of colorectal anastomotic perfusion: a feasibility study. Colorectal Dis 2013;15(1):91-6.

2. Ris F, Hompes R, Cunningham C, Lindsey I, Guy R, Jones O, et al. Near-infrared (NIR) perfusion angiography in minimally invasive colorectal surgery. Surg Endosc 2013;28(7):2221-6.

3. Ha GW, Kim JH, Lee MR. Oncologic impact of anastomotic leakage following colorectal cancer surgery: a systematic review and meta-analysis. Ann Surg Oncol 2017;24(11):3289-99.

4. Park JS, Choi GS, Kim SH, Kim HR, Kim NK, Lee KY, et al. Multicenter analysis of risk factors for anastomotic leakage after laparoscopic rectal cancer excision: the Korean laparoscopic colorectal surgery study group. Ann Surg 2013;257(4):665-71.

5. Zhang W, Lou Z, Liu Q, Meng R, Gong H, Hao L, et al. Multicenter analysis of risk factors for anastomotic leakage after middle and low rectal cancer resection without diverting stoma: a retrospective study of 319 consecutive patients. Int J Colorectal Dis 2017;32(10):1431-7.

6. Smith SR, Pockney P, Holmes R, Doig F, Attia J, Holliday E, et al. Biomarkers and anastomotic leakage in colorectal surgery: C-reactive protein trajectory is the gold standard. ANZ J Surg 2017;88(5):440-4.

7. Jafari MD, Lee KH, Halabi WJ, Mills SD, Carmichael JC, Stamos MJ, et al. The use of indocyanine green fluorescence to assess anastomotic perfusion during robotic assisted laparoscopic rectal surgery. Surg Endosc 2013;27(8):3003-8.

8. Karliczek A, Harlaar NJ, Zeebregts CJ, Wiggers T, Baas PC, van Dam GM. Surgeons lack predictive accuracy for anastomotic leakage in gastrointestinal surgery. Int J Colorectal Dis 2009;24(5):569-76.

9. Vignali A, Gianotti L, Braga M, Radaelli G, Malvezzi L, Di Carlo V. Altered microperfusion at the rectal stump is predictive for rectal anastomotic leak. Dis Colon Rectum 2000;43(1):76-82.

10. Nachiappan S, Askari A, Currie A, Kennedy RH, Faiz O. Intraoperative assessment of colorectal anastomotic integrity: a systematic review. Surg Endosc 2014;28(9):2513-30.

11. van den Bos J, Al-Taher M, Schols RM, van Kuijk S, Bouvy ND, Stassen LPS. Near-infrared fluorescence imaging for real-time intraoperative guidance in anastomotic colorectal surgery: a systematic review of literature. J Laparoendosc Adv Surg Tech A 2018;28(2):157-67.

12. Blanco-Colino R, Espin-Basany E. Intraoperative use of ICG fluorescence imaging to reduce the risk of anastomotic leakage in colorectal surgery: a systematic review and meta-analysis. Tech Coloproctol. 2017

13. Boni L, David G, Mangano A, Dionigi G, Rausei S, Spampatti S, et al. Clinical applications of indocyanine green (ICG) enhanced fluorescence in laparoscopic surgery. Surg Endosc 2015;29(7):2046-55.

14. Kudszus S, Roesel C, Schachtrupp A, Hoer JJ. Intraoperative laser fluorescence angiography in colorectal surgery: a noninvasive analysis to reduce the rate of anastomotic leakage. Langenbeck's archives of surgery. Deutsche Gesellschaft fur Chirurgie 2010;395(8):1025-30.

15. Diana M, Agnus V, Halvax P, Liu YY, Dallemagne B, Schlagowski Al, et al. Intraoperative fluorescencebased enhanced reality laparoscopic real-time imaging to assess bowel perfusion at the anastomotic site in an experimental model. Br J Surg 2015;102(2):e169-76.

16. Facy $O$, Paquette $B$, Orry D, Santucci $N$, Rat $P$, Rat $P$, et al. Inflammatory markers as early predictors of infection after colorectal surgery: the same cut-off values in laparoscopy and laparotomy? Int J Colorectal Dis 2017;32(6):857-63.

17. Reynolds IS, Boland MR, Reilly F, Deasy A, Majeed MH, Deasy J, et al. C-reactive protein as a predictor of anastomotic leak in the first week after anterior resection for rectal cancer. Colorectal Dis 2017; 19(9):812-8.

18. Munoz JL, Alvarez MO, Cuquerella V, Miranda E, Pico C, Flores R, et al. Procalcitonin and C-reactive protein as early markers of anastomotic leak after laparoscopic colorectal surgery within an enhanced recovery after surgery (ERAS) program. Surg Endosc 2018;32(9):4003-10.

19. Relja B, Szermutzky M, Henrich D, Maier M, de Haan JJ, Lubbers T, et al. Intestinal-FABP and liver-FABP: Novel markers for severe abdominal injury. Acad Emerg Med 2010;17(7):729-35. 
20. Schellekens DH, Grootjans J, Dello SA, van Bijnen AA, van Dam RM, Dejong CH, et al. Plasma intestinal fatty acid-binding protein levels correlate with morphologic epithelial intestinal damage in a human translational ischemia-reperfusion model. J Clin Gastroenterol 2014;48(3):253-60.

21. Reisinger KW, Poeze M, Hulsewe KW, van Acker BA, van Bijnen AA, Hoofwijk AG, et al. Accurate prediction of anastomotic leakage after colorectal surgery using plasma markers for intestinal damage and inflammation. J Am Coll Surg 2014;219(4):744-51.

22. Jongen AC, Bosmans JW, Kartal S, Lubbers T, Sosef M, Slooter GD, et al. Predictive factors for anastomotic leakage after colorectal surgery: study protocol for a prospective observational study (REVEAL Study). JMIR Res Protoc 2016;5(2):e90.

23. Rahbari NN, Weitz J, Hohenberger W, Heald RJ, Moran B, Ulrich A, et al. Definition and grading of anastomotic leakage following anterior resection of the rectum: a proposal by the International Study Group of Rectal Cancer. Surgery 2010;147(3):339-51.

24. Kawada K, Hasegawa S, Hida K, Hirai K, Okoshi K, Nomura A, et al. Risk factors for anastomotic leakage after laparoscopic low anterior resection with DST anastomosis. Surg Endosc 2014;28(10):2988-95.

25. Boni L, Fingerhut A, Marzorati A, Rausei S, Dionigi G, Cassinotti E. Indocyanine green fluorescence angiography during laparoscopic low anterior resection: results of a case-matched study. Surg Endosc 2017;31(4):1836-40.

26. Boni L, David G, Dionigi G, Rausei S, Cassinotti E, Fingerhut A. Indocyanine green-enhanced fluorescence to assess bowel perfusion during laparoscopic colorectal resection. Surg Endosc 2016;30(7):2736-42.

27. Kin $\mathrm{C}$, Vo $\mathrm{H}$, Welton L, Welton $M$. Equivocal effect of intraoperative fluorescence angiography on colorectal anastomotic leaks. Dis Colon Rectum 2015;58(6):582-7.

28. Hellan M, Spinoglio G, Pigazzi A, Lagares-Garcia JA. The influence of fluorescence imaging on the location of bowel transection during robotic left-sided colorectal surgery. Surg Endosc 2014;28(5):1695-702.

29. Jafari MD, Wexner SD, Martz JE, McLemore EC, Margolin DA, Sherwinter DA, et al. Perfusion assessment in laparoscopic left-sided/anterior resection (PILLAR II): a multi-institutional study. I Am Coll Surg 2015;220(1):82-92 e1.

30. van den Bos J, Wieringa FP, Bouvy ND, Stassen LPS. Optimizing the image of fluorescence cholangiography using ICG: a systematic review and ex vivo experiments. Surg Endosc 2018;32(12): 4820-32.

31. Bilgin IA, Hatipoglu E, Aghayeva A, Arikan AE, Incir S, Mamal Torun M, et al. Predicting value of serum procalcitonin, c-reactive protein, drain fluid culture, drain fluid interleukin-6, and tumor necrosis factoralpha levels in anastomotic leakage after rectal resection. Surg Infect 2017;18(3):350-6.

32. Johne B, Fagerhol MK, Lyberg T, Prydz H, Brandtzaeg P, Naess-Andresen CF, et al. Functional and clinical aspects of the myelomonocyte protein calprotectin. Mol Pathol 1997;50(3):113-23.

33. Cikot M, Kones O, Gedikbasi A, Kocatas A, Karabulut M, Temizgonul KB, et al. The marker C-reactive protein is helpful in monitoring the integrity of anastomosis: plasma calprotectin. Am J Surg 2016; 212(1):53-61.

34. Bingold TM, Franck K, Holzer K, Zacharowski K, Bechstein WO, Wissing H, et al. Intestinal fatty acid binding protein: a sensitive marker in abdominal surgery and abdominal infection. Surg Infect 2015; 16(3):247-53. 



\section{Part III}

Considerations regarding perioperative care of the colorectal surgery patient 



\section{Chapter}

Contrast enema vs. colonoscopy prior to temporary stoma reversal in rectal surgery; results of a national snapshot study

Audrey CHM Jongen, Yannick M Meyer, Laurents PS Stassen, Joep PM Derikx, Nicole D Bouvy, on behalf of the Dutch Snapshot Research Group

In preparation 


\section{Abstract}

Introduction

Colorectal anastomotic leakage (CAL) is the most feared complication following surgery of the colon and rectum. Surgeons may choose to construct a deviating ostomy to diminish the clinical sequelae of a leak. Prior to temporary stoma closure, it is common practice to assess the integrity of the anastomosis by either $x$-ray with contrast enema (CE) or colonoscopy. The aim of this study was to investigate whether CE or colonoscopy is the most accurate tool to assess anastomotic integrity prior to temporary stoma reversal.

Methods

The present study included all patients who underwent rectal cancer resection with the construction of an anastomosis and deviating ostomy in 2011, from a collaborative cross-sectional study performed in 71 Dutch hospitals. From a total of 2095 patients, 997 patients underwent a Low Anterior Resection (LAR) with the construction of an anastomosis. Of these, 260 cases were excluded as no defunctioning ileostomy was constructed. In 584 cases information about the assessment of anastomotic integrity was reported. When taking into account only the deviating ostomies that were reversed, a total of 420 patients were included in the study, of which 285 had their anastomoses assessed using CE, whereas 135 assessments were done by means of colonoscopy.

Results

The majority of constructed deviating stomas were ileostomies (74.3\%). The number of anastomotic leaks diagnosed by either modality within 30 days after employment was not significantly different (4.2 vs. 5.2\% for CE and colonoscopy, respectively, OR 3.79, $95 \% \mathrm{Cl} 0.468-30.606, \mathrm{P}=0.21)$.

Conclusion

No significant difference in the number of CAL cases detected by either CE or colonoscopy could be detected prior to temporary stoma reversal in patients who underwent rectal cancer resection. 


\section{Introduction}

Colorectal anastomotic leakage (CAL) is a frequently occurring complication after colorectal surgery with an incidence of $8-20 \%$ in the Netherlands ${ }^{1}$. CAL results in increased morbidity, mortality rates of up to $40 \%$ and is even associated with a poor oncological outcome that reflects in a shorter disease free survival and a higher risk of local tumor recurrence ${ }^{2-7}$. CAL leads to a fivefold increase in health care costs due to high numbers of reoperation and Intensive Care Unit-admission as compared to a normal postoperative course ${ }^{8}$. Risk factors for anastomotic leakage include: male gender, smoking, obesity, distal anastomosis, tumor size, ASA grade higher than II, diabetes and other comorbidities (including vascular, pulmonary and renal disease), preoperative use of steroid- and non-steroidal anti-inflammatory drugs, longer duration of the operation, emergency surgery and contamination of the operative field $d^{9,10}$. In order to minimize the clinical consequences of such a leak the surgeon may opt to perform a temporary deviating ostomy, which is usually reversed after 8 to 12 weeks ${ }^{3}$.

Before removal of the temporary ostomy it is common practice to assess the integrity of the previously created anastomosis in order to decrease the risk to develop anastomotic leakage. However, some controversy exists as to which method is the most suitable for this assessment. This is partially due to a paucity of research on the subject. Another complicating factor is a lack of consensus about the definition of anastomotic leakage, making it difficult to compare study results ${ }^{11,12}$. Two methods used to evaluate anastomotic integrity prior to stoma reversal are contrast enema and colonoscopy ${ }^{12}$.

The primary aim of this study is to investigate whether X-ray with contrast or colonoscopy is the most accurate tool to assess anastomotic integrity prior to temporary stoma reversal.

\section{Methods}

The data used in this study was obtained from the database of the Dutch Snapshot Research Group (DSRG). In 2015 the DSRG assembled a multi-center, retrospective, cross-sectional database of all the patients undergoing rectal cancer resections in 2011 in collaboration with the Dutch Surgical Colorectal Audit (DSCA). 71 out of 94 hospitals registering in the DSCA participated in the data collection. The retrospectively collected long-term data was subsequently combined with the short-term data that was available from the DSCA registration to form the final dataset.

A total of 2095 patients were included in the original dataset. From this dataset 997 patients were selected who underwent a low anterior resection (LAR) for further 
analysis. Of those patients, 737 had received a deviating ostomy either prior to or during the operation. Patients with a primary anastomosis without a defunctioning stoma were excluded. For this specific research question, only patients were included who had undergone assessment of the integrity of the anastomosis prior to temporary stoma reversal, either by means of colonoscopy or x-ray with contrast enema (CE). One hundred and thirty patients of these did not undergo assessment of anastomosis integrity, and information regarding this was lacking in 23 cases. A total of 584 patients did undergo integrity assessment of their anastomosis, of which 34 patients underwent CT with rectal contrast shortly after the index surgery because of clinical symptoms of CAL and were excluded. The final study population existed of a total of 420 patients who had their temporary deviating ostomies reversed (see Figure 6.1 for a flowchart of the selection process).

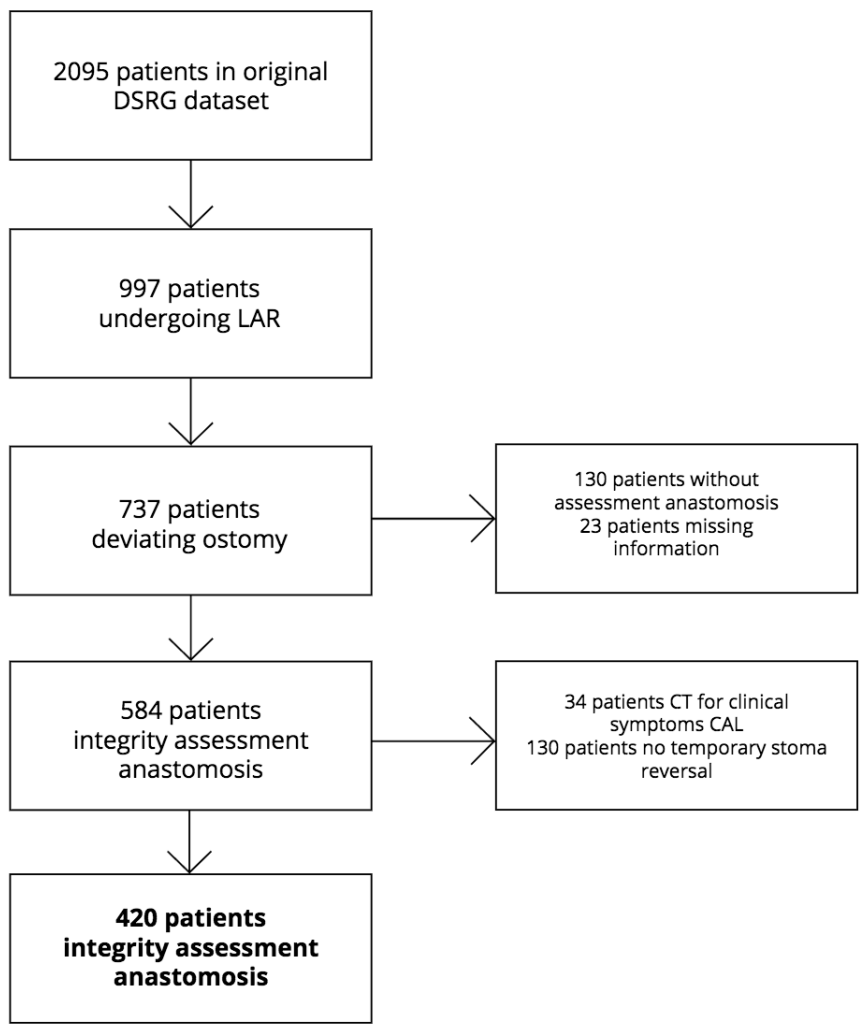

Figure 6.1 Flowchart of the selection process. 
In order to control for the possibility that the diagnosis of CAL was established in any other manner than with the diagnostic modalities that are the focus of this study, only cases of CAL that were diagnosed within 30 days following the diagnostics were included.

The following data were collected: patient characteristics, type of operation and anastomosis, presence of deviating ostomy, type of ostomy, method of assessing integrity anastomosis, occurrence of postoperative or stoma-related complications, and date of diagnosis CAL.

The mean follow-up after the index surgery was 40,41 months (11,50 months SD).

CAL was defined as the presence of any of the following factors: contrast extravasation on imaging studies, presacral collection requiring surgical or radiological or endoscopic intervention, or a presacral collection that either led to delay in stoma reversal or let to resection or reconstruction of the anastomosis.

\section{Statistics}

Statistical significance was defined as $P<0.05$. A Student's $t$-test was used to control for baseline differences of continuous variables, whereas the $\chi^{2}$ test was used for categorical variables. The reported incidence of anastomotic leakage was determined after examination through either colonoscopy or CE prior to stoma reversal. Because the outcomes (i.e. $\mathrm{AL}$ or no $\mathrm{AL}$ ) of the diagnostics tests were not reported in the database, it was not possible to directly calculate the specificity and sensitivity of the tests. Instead, it was chosen to compare the post-test incidence of both diagnostic methods using Odds Ratio. In this particular study, the Odds Ratio is used to examine the correlation between the test used and the incidence of anastomotic leakage. If the Odds Ratio is 1, this indicates that both tests diagnose the same number of cases of anastomotic leakage, thus the tests are of equal value for detecting anastomotic leakage. An Odds ratio that is either larger or smaller than 1 means that during the period following one of the tests groups, a higher incidence of anastomotic leakage was reported. If the confounders are balanced between groups this difference is the result of a difference in diagnostic value, in other words: one of the tests is detecting more cases of anastomotic leakage than the other.

\section{Demographics}

A total of 997 patients were identified from the original dataset $(n=2095)$ that underwent LAR for rectal carcinoma. The total leakage rate in this cohort was $25.2 \%$. Cases of anastomotic leakage $(n=164)$ as well as cases of chronic sinus $(n=87)$ were included in these numbers. 737 of the patients from the original database had received a 
deviating ostomy either prior to or during the operation. For further analysis, a total of 420 patients were included who received a colorectal anastomosis with construction of a diverting ostomy during the initial operation, and who had undergone assessment of the integrity of the anastomosis prior to stoma reversal.

285 out of these 420 anastomoses (70.3\%) were assessed for integrity using radiodiagnostics with contrast enema, while 135 assessments (29.7\%) were done by means of colonoscopy. A number of patients were diagnosed with CAL before assessment of integrity of the anastomosis, either by CE ( $n=16$ leaks) or by means of colonoscopy ( $n=7$ leaks). These cases were not taken into account for the analyses regarding the use of the diagnostic tools, as they do not contribute to answering the research question (see Table 6.1 for an overview of timing of diagnosis of the anastomotic leaks).

Table 6.1 Timing of CAL diagnosis.

\begin{tabular}{lcc}
\hline Timing of CAL diagnosis & \multicolumn{2}{c}{ Study group } \\
\cline { 2 - 3 } & $\begin{array}{c}\text { Contrast enema } \mathrm{n}=285 \\
\mathrm{n}(\% \text { of total leakage) }\end{array}$ & $\begin{array}{c}\text { Colonoscopy } \mathrm{n}=135 \\
\mathrm{n}(\% \text { of total leakage) }\end{array}$ \\
\hline Prior to integrity assessment & $16(57.1)$ & $7(50)$ \\
$<30$ days after assessment & $8(28.6)$ & $1(7.1)$ \\
$>30$ days after assessment & $4(14.3)$ & $6(42.9)$ \\
Total number of leakage & 28 & 14 \\
\hline
\end{tabular}

Of the 285 patients in the contrast enema group, 8 (2.8\%) were diagnosed with anastomotic leakage within 30 days after employment of either diagnostic modality, the number of leaks increased to 12 (4.2\%) when taking into account all leakages that were diagnosed before stoma reversal. In the colonoscopy group, one out of 135 patients (0.7\%) was diagnosed with CAL within 30 days after colonoscopy, these numbers increased to 7 (5.2\%) before stoma reversal (Odds ratio within 30 days: $3.79,95 \% \mathrm{Cl}$ 0.469-30.606, $\mathrm{P}=0.21$, Odds ratio total leakages: 0.812; 95\% Cl 0.313-2.109, $\mathrm{P}=0.67)$. See Table 6.1 for an overview of the demographics of both study groups.

The mean duration of the interval between assessment of the anastomotic integrity and stoma reversal was 11.2 weeks (SD 13,00) for the CE group, compared to 15,7 weeks (SD 31.73) for the colonoscopy group.

Most of the anastomoses created during the index operation in both groups were sideto-end anastomoses (208 cases; $73.0 \%$ vs. 95 cases; 70.1\% for the CE and colonoscopy group, respectively), followed by end-to-end anastomoses (62 cases; $21.8 \%$ vs. 35 cases $26.0 \%$ ) and colon pouches in 2 patients of the CE group (0.7\%), none of these differences were significant. The majority of these anastomoses were stapled: 
267 anastomoses (96.8\%) in the enema group and 132 anastomoses in the colonoscopy group (97.8\%).

Table 6.2 Patient demographics.

\begin{tabular}{|c|c|c|c|}
\hline \multirow[t]{2}{*}{ Characteristic } & \multicolumn{2}{|c|}{ Study group } & \multirow[t]{2}{*}{$\mathrm{P}$} \\
\hline & Contrast enema $(n=285)$ & Colonoscopy $(n=135)$ & \\
\hline Sex & & & 0.931 \\
\hline Male & $187(65.6 \%)$ & $88(65.2 \%)$ & \\
\hline Female & $98(34.4 \%)$ & $47(34.8 \%)$ & \\
\hline Age (SD, yr) & $67.4(10.6)$ & $70.1(9.9)$ & 0.013 \\
\hline Follow-up (SD, months) & $40.4(11.6)$ & $40.4(11.0)$ & 0.991 \\
\hline ASA $n(\%)$ & & & 0.887 \\
\hline I & 99 (34.7\%) & $43(31.9 \%)$ & \\
\hline ॥ & $150(52.6 \%)$ & $72(53.3 \%)$ & \\
\hline III & $30(10.5 \%)$ & $15(11.11 \%)$ & \\
\hline Comorbidity n (\%) & $182(63.9 \%)$ & $81(60,0 \%)$ & 0.597 \\
\hline Anastomosis type n (\%) & & & 0.425 \\
\hline Side-to-end & $208(73.0 \%)$ & 95 (70.4\%) & \\
\hline End-to-End & $62(21.8 \%)$ & $35(26.0 \%)$ & \\
\hline Colon pouch & $2(0.7 \%)$ & - & \\
\hline Stoma type $n(\%)$ & & & 0.403 \\
\hline lleostomy & $239(83.9 \%)$ & $73(77.8 \%)$ & \\
\hline Colonostomy & $26(9.1 \%)$ & $17(12.6 \%)$ & \\
\hline Anastomosis technique $\mathrm{n}(\%)$ & & & 0.959 \\
\hline Stapled & $276(96.8 \%)$ & $132(97.8 \%)$ & \\
\hline Hand-sewn & $4(1.4 \%)$ & $2(1.5 \%)$ & \\
\hline Laparoscopy/laparotomy n (\%) & & & 0.015 \\
\hline Laparoscopy & $154(54.0 \%)$ & 75 (55.5\%) & \\
\hline Laparotomy & 125 (43.9\%) & $55(40.7 \%)$ & \\
\hline Conversion n (\%) & $21(7.4 \%)$ & $9(6.7 \%)$ & 0.807 \\
\hline Peroperative complications n (\%) & & & 0.949 \\
\hline Bleeding & $3(1.1 \%)$ & - & \\
\hline Intestinal defect & $2(0.7 \%)$ & $2(1.5 \%)$ & \\
\hline
\end{tabular}

\section{Results}

We examined potential confounders by examining correlation of age, sex, comorbidity and open versus laparoscopic operation with the incidence of anastomotic leakage in both groups. All the variables with a P-value $<0.20$ at univariate analysis (in this case age and open/laparoscopic surgery) were taken into account in a multivariable analysis. Neither showed a statistically significant correlation with the occurrence of anastomotic leakage in our cohort (results not shown).

Univariate logistic regression revealed an Odds Ratio (OR) of 0.812 (in favor of the colonoscopy) when comparing the odds of anastomotic leakage in the CE group to the 
colonoscopy group for the full duration of follow-up (95\% Cl: 0.313-2.109, $\mathrm{P}=0.667$ ). When taking into account only the cases diagnosed within 30 days after employment of either diagnostic modality, an OR of 3.78 was found in favor of the contrast enema (95\% Cl: 0.469-30.606, P=0.21) (Table 6.3).

Table 6.3 Univariate analysis (Logistic Regression).

\begin{tabular}{lccc}
\hline & \multicolumn{2}{c}{ Univariate analysis } & \\
Factor & Odds ratio & $95 \% \mathrm{Cl}$ & $\mathrm{P}$ \\
\hline Contrast enema/colonoscopy & & & \\
CAL diagnosed < 30 days & 3.790 & $0.469-30.606$ & 0.210 \\
Total CAL cases diagnosed after assessment & 0.812 & $0.313-2.109$ & 0.667 \\
\hline
\end{tabular}

\section{Discussion}

Anastomotic leakage remains one of the most dreaded complications after colorectal surgery. Due to patient expectations and technological advancement in the field of colorectal surgery, low rectal and anal anastomoses are constructed in increasing numbers. This has led to the fact that in a rising number of cases, a temporary deviating ostomy is constructed proximal to the anastomotic site ${ }^{13}$. Routine usage of such a deviating ostomy has long been subject to discussion and the general consensus is that this practice does not decrease the incidence of anastomotic leakage ${ }^{14-16}$. However, several studies indicate that construction of a temporary ostomy may mitigate the consequences of an anastomotic leak ${ }^{15-17}$. Others advise to refrain from the creation of temporary deviating ostomies, because of the complications associated with this procedure ${ }^{18-20}$. Stoma complications have a reported incidence of up to $30 \%$ and range from skin complications and high stoma output to parastomal herniation and stoma prolapse, which often requires reoperation ${ }^{14,21}$. Furthermore, closure of an ostomy exposes the patient to another operation and its associated complications, including anastomotic leakage. Lastly, up to $20 \%$ of all the temporary ostomies will never be reversed, which severely affects Quality of Life $(\mathrm{Q} O \mathrm{~L})^{14,21,22}$.

Besides the risk of abdominal sepsis that exists upon closure of a temporary stoma in the presence of an incompletely healed anastomosis, Killeen et al. showed that even clinically occult leaks could severely impact bowel-specific QoL ${ }^{23}$. A variety of diagnostic modalities can be used to assess the quality of the anastomosis after colorectal surgery. Despite the frequent use of these diagnostic tools prior to temporary stoma reversal, no clear consensus exists on whether routine assessment of the integrity of the 
anastomosis is necessary, and which diagnostic tool is most suitable ${ }^{3,24-27}$. Besides contrast imaging, which is most commonly used, colonoscopy is also employed to assess the quality of the anastomosis prior to stoma reversal, but very little scientific evidence exists for the use of colonoscopy for means other than intraoperative assessment or assessment of cancer recurrence ${ }^{28-30}$. Another important indication for the performance of these tests is to determine the presence of a stenosis at the anastomotic site.

In this study we retrospectively compared two most commonly used techniques of assessing anastomotic integrity after colorectal surgery: contrast enema and colonoscopy.

Contrast enema has been reported to have relatively high sensitivity and specificity for colorectal anastomotic leakage in the presence of clinical signs ${ }^{12,31}$. However, there are several drawbacks to this diagnostic method. It has been shown that with a negative test, reversal is unlikely to result in abdominal sepsis or anastomotic leakage, but, on the other hand, that many cases with an abnormal test result could also be safely reversed ${ }^{12,32,33}$. Indeed, CE detects a large number of radiological leaks without clinical symptoms - up to $41 \%$ - that may not require intervention ${ }^{31}$. These cases may be caused by the accumulation of contrast in the 'dog ears' of the staple line ${ }^{34}$, or may represent leaks with only very minor anastomotic sinuses, that do not cause any clinical symptoms $^{32}$. Some authors raised concerns regarding the pressure increase and associated risk of mechanical disruption ${ }^{11}$, but the use of water-soluble contrast enema is generally considered to be a safe measure to evaluate anastomotic integrity ${ }^{11,12,26}$. Its routine use prior to ileostomy closure, on the other hand, remains a matter of debate ${ }^{32}$. Recent evidence suggests that CE has little additional value next to digital rectal examination for the very low anastomoses or next to colonoscopy ${ }^{32}$.

As stated before, very little literature exists on the routine use of colonoscopy as a means to evaluate the quality of the anastomosis, although it was used relatively frequent in this study population. Several authors however describe its application after LAR to assess the anastomoses that are too high to be examined by digital palpation ${ }^{27}$. Endoscopic evaluation is generally regarded safe in use, readily available and associated with low costs. An additional benefit of the use of colonoscopy is the detection of although rare - intraluminal colorectal cancer recurrence, as well as metachronous (or missed synchronous) cancers and advanced adenomas ${ }^{30}$. It has been shown that these lesions can be found within two years of surgery ${ }^{35}$. The mean time in this specific patient population between primary surgery and the use of either diagnostic method was relatively long, which would support the use of colonoscopy as a screening tool. Colonoscopy could also aid in the assessment of (benign) anastomotic stenosis, which 
occurs in up to $30 \%$ of cases $^{36}$, and the modality can also be deployed to resolve short stenoses by means of balloon dilation ${ }^{37}$.

One of the main limitations of our study is that, as stated before, the outcomes of the diagnostic tests were not available for analysis. This was due to the retrospective nature of the study. Therefore, to ensure that the diagnosis was established based only on the results from the colonoscopy or contrast enema without any following diagnostic measures, only patients who were diagnosed with colorectal anastomotic leakage within 30 days after examination were included in the study. It cannot be completely ruled out that other additional diagnostic tools were used to establish the diagnosis, which could interfere with the observed differences between our tests of interest, especially when taking into account the full duration of follow-up after either examination. Information regarding complications following the two diagnostic modalities (bleeding, perforation or sensitivity to contrast) was unfortunately not included in the database and could therefore not be taken into account in this study. Another limitation is the lack of insight in the motivation of surgeons to choose for a particular test in a specific case; preferred use of one of the diagnostic tests to examine high-risk cases would lead to an overestimation of the effect of the diagnostic method in our study.

No significant difference was found in the odds of the diagnosis of anastomotic leakage between the two imaging modalities. This may be partially due to the small number of patients that developed anastomotic leakage in both groups $(4,2 \%$ in the enema group and $5,2 \%$ in the colonoscopy group). Univariate analysis did not reveal a significant influence of other risk factors. An Odds ratio of 3,790 for detecting colorectal anastomotic leakage in favor of the contrast enema $(P=0,21)$ within 30 days after the examination is a relatively small difference. Furthermore, when taking into account all of the cases of CAL that were diagnosed after use of both diagnostic tools, an OR of 0,667 $(P=0,667)$ was found in favor of the colonoscopy. From these results, no preference arises for one of these modalities over the other, leaving the choice between the two diagnostic options to the preference of the surgeon. However, colonoscopy has several additional advantages over contrast enema, as it can also detect intraluminal cancer recurrence, metachronous cancer and anastomotic stricture. As mentioned before, it has been suggested that assessment of the integrity of the anastomosis should be reserved for selected patients with for example a positive intraoperative air leak test and/or complications during the postoperative period. To strengthen these suggestions, the performance of a four-armed RCT with and without routine integrity assessment and with colonoscopy or contrast enema is needed, which would unfortunately require rather large sample size. 


\section{Conclusion}

No significant difference could be found in the ability of detecting colorectal anastomotic leakage between contrast enema and colonoscopy prior to temporary stoma reversal. An RCT is needed before strong recommendations can be made regarding routine use of either diagnostic tool. 


\section{References}

1. Borstlap WAA, Westerduin E, Aukema TS, et al. Anastomotic leakage and chronic presacral sinus formation after low anterior resection: results from a large cross-sectional study. Ann Surg 2017;266(5): 870-7.

2. Ikeda T, Kumashiro R, Taketani K, et al. Endoscopic evaluation of clinical colorectal anastomotic leakage. J Surg Res 2015;193(1):126-34.

3. Khair G, Alhamarneh $\mathrm{O}$, Avery J, et al. Routine use of gastrografin enema prior to the reversal of a loop ileostomy. Dig Sur 2007;24(5):338-41.

4. Kube R, Mroczkowski P, Granowski D, et al. Anastomotic leakage after colon cancer surgery: a predictor of significant morbidity and hospital mortality, and diminished tumour-free survival. Eur J Surg Oncol 2010;36(2):120-4.

5. Branagan G, Finnis D, Wessex Colorectal Cancer Audit Working G. Prognosis after anastomotic leakage in colorectal surgery. Dis Colon Rectum 2005;48(5):1021-6.

6. McArdle CS, McMillan DC, Hole DJ. Impact of anastomotic leakage on long-term survival of patients undergoing curative resection for colorectal cancer. Br J Surg 2005;92(9):1150-4.

7. Khan AA, Wheeler JM, Cunningham $C$, et al. The management and outcome of anastomotic leaks in colorectal surgery. Colorectal Dis 2008;10(6):587-92.

8. Koperna T. Cost-effectiveness of defunctioning stomas in low anterior resections for rectal cancer: a call for benchmarking. Arch Surg 2003;138(12):1334-8; discussion 9.

9. Daams F, Luyer M, Lange JF. Colorectal anastomotic leakage: aspects of prevention, detection and treatment. World J Gastroenterol 2013;19(15):2293-7.

10. McDermott FD, Heeney A, Kelly ME, et al. Systematic review of preoperative, intraoperative and postoperative risk factors for colorectal anastomotic leaks. Br J Surg 2015;102(5):462-79.

11. Hirst NA, Tiernan JP, Millner PA et al. Systematic review of methods to predict and detect anastomotic leakage in colorectal surgery. Colorectal Dis 2014;16(2):95-109.

12. Habib K, Gupta A, White D, et al. Utility of contrast enema to assess anastomotic integrity and the natural history of radiological leaks after low rectal surgery: systematic review and meta-analysis. Int J Colorectal Dis 2015;30(8):1007-14.

13. Codd RJ, Evans MD, Davies M, et al. Permanent stoma rates: a misleading marker of quality in rectal cancer surgery. Colorectal Dis 2014;16(4):276-80.

14. Gessler B, Haglind E, Angenete E. Loop ileostomies in colorectal cancer patients--morbidity and risk factors for nonreversal. J Surg Res 2012;178(2):708-14.

15. Shiomi A, Ito M, Maeda K, et al. Effects of a diverting stoma on symptomatic anastomotic leakage after low anterior resection for rectal cancer: a propensity score matching analysis of 1,014 consecutive patients. J Am Coll Surg 2015;220(2):186-94.

16. Wong NY, Eu KW. A defunctioning ileostomy does not prevent clinical anastomotic leak after a low anterior resection: a prospective, comparative study. Dis Colon Rectum 2005;48(11):2076-9. 0

17. Matthiessen P, Hallbook O, Rutegard J, et al. Defunctioning stoma reduces symptomatic anastomotic leakage after low anterior resection of the rectum for cancer: a randomized multicenter trial. Ann Surg 2007;246(2):207-14.

18. Remzi FH, Fazio VW, Gorgun E, et al. The outcome after restorative proctocolectomy with or without defunctioning ileostomy. Dis Colon Rectum 2006;49(4):470-7.

19. Mowschenson PM, Critchlow JF, Peppercorn MA. Ileoanal pouch operation: long-term outcome with or without diverting ileostomy. Arch Surg 2000;135(4):463-5; discussion 5-6.

20. Ikeuchi $\mathrm{H}$, Nakano $\mathrm{H}$, Uchino $\mathrm{M}$, et al. Safety of one-stage restorative proctocolectomy for ulcerative colitis. Dis Colon Rectum 2005;48(8):1550-5.

21. den Dulk M, Smit M, Peeters KC, et al. A multivariate analysis of limiting factors for stoma reversal in patients with rectal cancer entered into the total mesorectal excision (TME) trial: a retrospective study. Lancet Oncol 2007;8(4):297-303.

22. Pan HD, Peng YF, Wang $L$, et al. Risk Factors for Nonclosure of a Temporary Defunctioning lleostomy Following Anterior Resection of Rectal Cancer. Dis Colon Rectum 2016;59(2):94-100. 
23. Killeen $\mathrm{S}$, Souroullas $\mathrm{P}$, Ho Tin $\mathrm{H}$, et al. Outcomes of asymptomatic anastomotic leaks found on routine postoperative water-soluble enema following anterior resection for cancer. World J Surg 2013;37(11):2700-4 .

24. Dimitriou N, Panteleimonitis S, Dhillon A, et al. Is the routine use of a water-soluble contrast enema prior to closure of a loop ileostomy necessary? A review of a single institution experience. World J Surg Oncol 2015;13:331.

25. Karsten BJ, King JB, Kumar RR. Role of water-soluble enema before takedown of diverting ileostomy for low pelvic anastomosis. Am Surg 2009;75(10):941-4.

26. Kalady MF, Mantyh CR, Petrofski J, et al. Routine contrast imaging of low pelvic anastomosis prior to closure of defunctioning ileostomy: is it necessary? J Gastrointest Surg 2008;12(7):1227-31.

27. Cowan T, Hill AG. lleostomy closure without contrast study is safe in selected patients. ANZ J Surg $2005 ; 75(4): 218-9$.

28. Shamiyeh A, Szabo K, Ulf Wayand W, et al. Intraoperative endoscopy for the assessment of circularstapled anastomosis in laparoscopic colon surgery. Surg Laparosc Endosc Percutan Tech 2012;22(1):65-7.

29. Li VK, Wexner SD, Pulido N, et al. Use of routine intraoperative endoscopy in elective laparoscopic colorectal surgery: can it further avoid anastomotic failure? Surg Endosc 2009;23(11):2459-65.

30. Pickhardt PJ, Edwards K, Bruining DH, et al. Prospective trial evaluating the surgical anastomosis at oneyear colorectal cancer surveillance: CT colonography versus optical colonoscopy and implications for patient care. Dis Colon Rectum 2017;60(11):1162-7.

31. Daams F, Wu Z, Lahaye MJ, et al. Prediction and diagnosis of colorectal anastomotic leakage: A systematic review of literature. World J Gastrointest Surg 2014;6(2):14-26.

32. Shalabi A, Duek SD, Khoury W. Water-soluble enema prior to ileostomy closure in patients undergoing low anterior resection: Is it necessary? J Gastrointest Surg 2016;20(10):1732-7.

33. Palmisano S, Piccinni G, Casagranda B, et al. The reversal of a protective stoma is feasible before the complete healing of a colorectal anastomotic leak. Am Surg 2011;77(12):1619-23.

34. Katory M, McLean R, Osman K, et al. The novel appearance of low rectal anastomosis on contrast enema following laparoscopic anterior resection: discriminating anastomotic leaks from "dog-ears" on watersoluble contrast enema and flexible sigmoidoscopy. Abdom Radiol 2017;42(2):435-41.

35. Rex DK, Kahi CJ, Levin B, et al. Guidelines for colonoscopy surveillance after cancer resection: a consensus update by the American Cancer Society and the US Multi-Society Task Force on Colorectal Cancer. Gastroenterology 2006;130(6):1865-71.

36. Luchtefeld MA, Milsom JW, Senagore A, et al. Colorectal anastomotic stenosis. Results of a survey of the ASCRS membership. Dis Colon Rectum 1989;32(9):733-6.

37. Garcea G, Sutton CD, Lloyd TD, et al. Management of benign rectal strictures: a review of present therapeutic procedures. Dis Colon Rectum 2003;46(11):1451-60. 


\section{Appendix S6.1}

\section{Supplementary information according to ARRIVE guidelines ${ }^{24}$}

- $\quad$ Muc2 $^{-/-}$mice backcrossed on C57BL/6 background between 8 and 16 weeks of age were used. Muc2 ${ }^{-/-}$mice on the $\mathrm{C} 57 \mathrm{BL} / 6$ background were bred as $\mathrm{Muc2}^{+/-} \times$ $\mathrm{MuC2}^{+/-}$at the Experimental Biomedicine animal facility at the University of Gothenburg, and offspring were genotyped.

- Mice were kept under standard conditions and provided with food and water ad libitum. Mice were housed together with their littermates, with a maximum of six companions per cage. The general health of mice was monitored several times per week for signs of inflammation, and animals were weighed once a week. During the experiment, animals were weighed daily and scored for discomfort twice daily.

- Scoring was performed according Pommergaard et al. ${ }^{25}$ :

\begin{tabular}{lll}
\hline Parameter & Grading & Score \\
\hline Activity & Normal/medium/low & $2 / 1 / 0$ \\
Fur & Smooth/fluffy/erect & $2 / 1 / 0$ \\
Eyes & Clean and open/clean and closed/dirty and closedt & $2 / 1 / 0$ \\
Able to stand straight & Yes/no & $1 / 0$ \\
Posture & Normal/modestly curled/fully curled up & $2 / 1 / 0$ \\
Position on feet & Normal/high & $1 / 0$ \\
Solitary & Yes/no & $0 / 1$ \\
Shivering & Yes/no & $0 / 1$ \\
\hline
\end{tabular}

Scoring was done by one researcher who was blinded for treatment at the time of scoring, while the other researcher performed preparation of the prostaglandin (PG) $\mathrm{E}_{2}$ or placebo syringes for peritoneal injection.

- Protocols were approved by the government animal ethics committee, and institutional animal use and care guidelines were followed (permit 63-2014).

- Mice were killed by intracardial puncture after isoflurane anaesthesia using an airstream of $2 \mathrm{l} / \mathrm{min}$ and 3.5 per cent isoflurane.

- A sample size calculcation was conducted before the experiment based on an expected reduction in the anastomotic leakage rate of 20 per cent. To detect a relevant difference in leakage reduction of 20 per cent $(\delta)$ between the different experimental groups with a variance of \pm 16 per cent $(\sigma)$, the number of animals per group should be: (power analysis $\alpha=0.05, \pi=0.8,2$-sided testing):

$$
\begin{aligned}
& n=2(z \alpha / 2-z \pi) 2 *(\sigma / \delta) 2(\text { Sachs }) \\
& n=2(1.96+0.84)^{2} *(16 / 20)^{2} \\
& n=15.7 * 0.64=10.03 \approx 11 / \text { group }
\end{aligned}
$$


- In total, 52 mice were used in this study. There were 11 animals per experimental group, and four groups (knockout versus control mice, with and without 16,16dimethyl $\mathrm{PGE}_{2}$ (dmPGE $_{2}$ supplementation). In addition, eight mice were killed to obtain control tissue (mesentaeric lymph nodes, spleen) for bacterial translocation analysis.

- Animals were matched for age and sex where possible, making it impossible to use randomization procedures. 



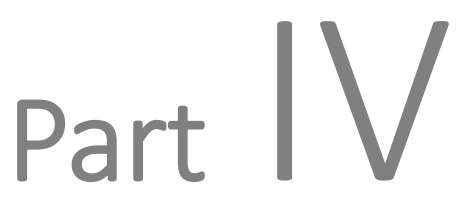

Novel insights in the physiology of anastomotic healing and leakage 



\section{Chapter}

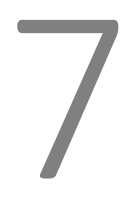

Comparison of three different application routes of butyrate to improve colonic anastomotic strength in rats

Joanna WAM Bosmans, Audrey CHM Jongen, Bas TC Boonen, Selwyn van Rijn, Francesca Scognamiglio, L. Stucchi, Marion JJ Gijbels, E. Marsich, Nicole D Bouvy Int J Colorectal Dis. 2017;32(2):305-313 


\section{Abstract}

Introduction

Despite extensive research, anastomotic leakage (AL) remains one of the most dreaded complications after colorectal surgery. Since butyrate enemas are known to enhance anastomotic healing, several administration routes have been explored in this study.

\section{Methods}

Three intraluminal approaches involving butyrate were investigated: (1) butyrinelucidating patch, (2) a single injection of hyaluronan-butyrate (HA-But) prior to construction of the proximal anastomosis and (3) rectal hyaluronan-butyrate (HA-But) enemas designed for distal anastomoses. The main outcome was AL and secondary outcomes were bursting pressure, histological analysis of the anastomosis, zymography to detect MMP activity and qPCR for gene expression of MMP2, MMP9, MUC2 and TFF3.

Results

Neither the patches nor the injections led to a reduction of $A L$ in experiments 1 and 2. In experiment 3, a significant reduction of AL was accomplished with the (HA-But) enema compared to the control group together with a higher bursting pressure. Histological analysis detected only an increased inflammation in experiment 2 in the hyaluronan injection group compared to the control group. No other differences were found regarding wound healing. Zymography identified a decreased proenzyme of MMP9 when HA-But was administered as a rectal enema. qPCR did not show any significant differences between groups in any experiment.

\section{Conclusion}

Butyrate enemas are effective in the enhancement of colonic anastomosis. Enhanced butyrate-based approaches designed to reduce $A L$ in animal models for both proximal and distal anastomoses were not more effective than were butyrate enemas alone. Further research should focus on how exogenous butyrate can improve anastomotic healing after gastrointestinal surgery. 


\section{Introduction}

Despite extensive research, anastomotic leakage $(\mathrm{AL})$ remains one of the most dreaded complications after colorectal surgery. It still results in high morbidity and mortality, and causes prolonged hospital stay and high healthcare costs ${ }^{1,2,3}$. Many studies have been performed regarding this subject, all aiming at improvement of anastomotic healing and thereby preventing leakage. Since the incidence of anastomotic leakage has not declined over the years, the need for a solution continues to exist ${ }^{4,5}$.

Previous animal studies have shown that rectal administration of butyrate-one of the predominant short chain fatty acids (SCFAs) - results in a higher bursting pressure in colonic anastomoses, thereby claiming an enhanced strength which may prevent anastomotic leakage $e^{6,7,8}$.

These positive results did not change current practice, nor have human studies been reported in which patients received postoperative butyrate enemas to enhance anastomotic strength. This is not surprising, when you consider that clinicians are not keen on enemas directly after surgery, especially when a fragile rectal anastomosis is involved. Water-soluble contrast enemas are often used to determine the presence of colorectal AL, mostly after rectum resection. However, these enemas are never given in the very early postoperative phase (<postoperative day 5) due to the potential risk of complications ${ }^{5}$. Another disadvantage of the use of enemas is the low compliance rate and the short and discontinuous exposure of butyrate to the colonic mucosa.

A recent study however showed that butyrate has remarkable anti-inflammatory and regenerative effects improving the repair of intestinal mucosa in rats with colitis ${ }^{9}$. Butyrate stimulates re-epithelisation and may influence collagen lysis by reducing matrix metalloproteinase (MMP) release ${ }^{10}$. Butyrate is a product of the fermentation process by bacteria that occurs mainly in the distal colon. Because it serves as the most important energy source for colonocytes ${ }^{11}$, our hypothesis is that increasing the concentration of butyrate will lead to an enhanced anastomotic healing in the colon. A number of studies indicate that butyrate affects the composition and thickness of the colonic mucus layer through alteration of mucin gene expression ${ }^{12}$ and nutritional deficiency of the colonic epithelium and that butyrate also can act as a signalling molecule through specific Gprotein-coupled receptors that are involved in the immune surveillance of the colonic mucosa towards microbial activity ${ }^{13}$. More recently, it has been shown that mice with an insufficient mucus layer on the colonic mucosa $\left(\mathrm{Muc2}^{-/-}\right.$) suffered more often from anastomotic leakage compared to control mice ${ }^{14}$. 
Furthermore, animal studies showed that butyrate enemas have a significant positive effect on the left colonic anastomoses, but this effect was weaker on the right side of the colon ${ }^{8}$. Obviously, not the same volume will reach the proximal anastomotic site compared to the distal anastomosis, which may explain these findings. Another explanation might be that the butyrate-producing bacteria mainly reside in the mucus layer at the distal part of the colon, that the proximal colon does not respond to a higher amount of butyrate, simply because the proximal enterocytes are not familiar to having that energy source available and are not able to use it. To increase the beneficial effect of butyrate, we added hyaluronan (HA), a glycosaminoglycan that is known to promote neovascularization, to enhance the process of scarring, and it has beneficial effects on cell proliferation in several tissues ${ }^{15,16}$. Hyaluronan also plays a role in the downregulation of the inflammatory response. Its free-radical scavenging and antioxidant properties and its supposed inhibiting effect on proteinases such as MMPs seem to be responsible for this downregulation, stabilizing the granulation tissue during the healing process ${ }^{16}$.

In this study, we investigated several ways to improve the proximal anastomotic strength by applying butyrate near this anastomosis: using a patch, injections and enemas. Our aim was to develop a method that resulted in a lower anastomotic leakage rate and more practical methods that can be applied in daily clinical practice.

\section{Methods}

\section{Animals}

Eighty-four Wistar rats with a body weight of 250-300 g were used. Animals were housed and cared for at the Central Animal Facility of Maastricht University. All animals were provided ad libitum access to food and water and were cared for according to local standards. Postoperatively, welfare assessment was performed twice daily using a standardized method and animals were given pain medication in case of discomfort. The experimental protocol complied with the Dutch Animal Experimental Act and was approved by the Animal Experimental Committee of Maastricht University Medical Centre. The ARRIVE guidelines for reporting in vivo experiments were followed ${ }^{17}$ (see also Supplementary Data S7.1). 


\section{Study design}

Primary objective of the study is to investigate if anastomotic leakage can be reduced in a leakage model by application of either an intraluminal butyrin-eluting patch, a singletime intraluminal administration of butyrate or a daily HA-But enema. For the proximal anastomoses, we used both an intraluminal butyrin-eluting patch that covered the anastomosis and a single-time intraluminal administration of hyaluronan-butyrate (HA-But). Since most research is performed in the distal part of the colon, we also used a left-colon anastomosis model to test the HA-But enemas. This resulted in the following three experiments:

- Experiment 1:

Butyrin-eluting patches (20 mass\% tributyrin) versus placebo patches ( $n=12 /$ group)

- Experiment 2:

HA-But injection ( $5 \% \mathrm{HA}, 60 \mathrm{mM}$ butyrate) versus $\mathrm{HA}$ injection ( $5 \% \mathrm{HA}$ ) versus saline injection $(0.9 \% \mathrm{NaCl})$ ( $\mathrm{n}=8 /$ group)

- Experiment 3:

Five millilitres of HA-But enema ( $5 \% \mathrm{HA}, 60 \mathrm{mM}$ butyrate) versus $5 \mathrm{~mL}$ sodium butyrate $(60 \mathrm{mM})$ enema versus a control group that received no enemas ( $n=12$ /group)

Patches were kindly provided by Polyganics (Groningen, the Netherlands), and enemas and injections were produced by Sigea (Trieste, Italy).

In all experiments, follow up was 7 days.

\section{Surgical procedure}

All rats received $0,05 \mathrm{mg} / \mathrm{kg}$ buprenorphine as analgesic and were anaesthetised using isoflurane. To acquire access to the abdominal cavity, a $5-\mathrm{cm}$ craniocaudal midline incision of the skin and abdominal musculature was made in all experiments. The cecum was then identified and moved outside of the peritoneal cavity and onto sterile gauzes that were hydrated with sterile saline solution to prevent dehydration. For proximal anastomoses, the colon was transected two centimetres distal from the cecum and an end-to-end anastomosis was created using four interrupted polypropylene 6/0 sutures (Prolene, Ethicon, Johnson \& Johnson) (Exp 1\& 2, see Supplementary Data S7.1). In experiment 3 , the anastomosis was performed in similar fashion but at $4 \mathrm{~cm}$ ab ani. After performing the anastomosis, the intestines were repositioned and the abdomen was closed in two layers, a running suture for the muscle layer (Vicryl 4-0, Ethicon, Inc) and interrupted sutures for the skin (Monocryl 4-0, Ethicon, Inc). 


\section{Macroscopic endpoints}

Anastomotic leakage was defined as (1) no anastomotic leakage, (2) small abscess at the anastomotic site $<1 \mathrm{~cm}^{3}$, (3) large $\left(>1 \mathrm{~cm}^{3}\right)$ abscess at the anastomotic site or (4) complete dehiscence with peritonitis/death due to faecal peritonitis. Adhesions to the anastomotic site were assessed according to van der Ham et al. ${ }^{19}$.

\section{Bursting pressure}

Bursting pressure was measured as previously described ${ }^{19}$. In short, a 5-cm segment of intestine including the anastomosis with adherent organs was resected en bloc and the part distal of the anastomosis was clamped. A plastic tube was inserted in the proximal end and ligated with a single polyglactine 4/0 suture (Vicryl, Ethicon). The complete anastomosis was immersed in phosphate-buffered saline, while air was infused using a manometer (IDEE, Maastricht University, the Netherlands) and pressure was manually increased by inflating the colon. Bursting pressure was defined as the intraluminal pressure at which air leakage was initially observed from the anastomosis (mBar).

\section{Tissue preparation}

In anaesthetised rats, the anastomotic site was dissected (after measuring bursting pressure) with a $0.5-\mathrm{cm}$ margin at each site of the anastomosis. Tissue samples were divided in three equal pieces: one for qPCR, one for zymography purposes and one for immunohistochemistry purposes. This latter one was cut in longitudinal direction and tissue was stretched and pinned onto a cork layer in order to secure a straight anastomotic line and improve quality of histological assessment prior to fixation in formalin (supplementary data S2). Sections were deparaffinized in xylene and rehydrated in graded ethanol to distilled water prior to performing histological staining. The part dedicated for qPCR analysis was snap frozen in liquid nitrogen and stored at $-80{ }^{\circ} \mathrm{C}$ until required for $\mathrm{mRNA}$ isolation.

\section{Histology and immunohistochemistry}

Sections were stained with standard haematoxylin-eosin and Picro Sirius Red using Direct Red 80 and Picric Acid solution (both Sigma-Aldrich, the Netherlands).

An independent, experienced animal pathologist performed blinded histological assessment on the obtained tissue, scoring (from 0 to 4 ) histological sections on inflammation, granulocyte influx, fibroblast activity and collagen deposition. Collagen 
ration was calculated using an in-house software program on pictures obtained with a polarized light microscope (Leica DM5000B, Leica Microsystems, Wetzlar, Germany).

\section{MMP2, pro-MMP9 and MMP9 activity analysis using zymography}

MMP2 and MMP9 activities were assessed using gelatin zymography since its increase of MMP activity has been implicated in the pathogenesis of $\mathrm{AL}^{20}$. Samples were lysed from tissue and loaded on a polyacrylamide gel containing gelatin (10\% Ready Zymogram Gel, Bio-Rad, the Netherlands). Gel electrophoresis took place at $100 \mathrm{~V}$ for $30 \mathrm{~min}$. After that, the gel was incubated with $2.5 \%$ Triton $\mathrm{X}-100$ in $\mathrm{MQ}$ for $30 \mathrm{~min}$ at room temperature. The gel was then placed in developing buffer at $37^{\circ} \mathrm{C}$ overnight. Colouring of the gel took place the following night with PAGE-Blue protein staining solution (Thermo Scientific, the Netherlands). At day 3, the staining was decoloured with $M Q$, revealing MMP2 and MMP9 activity. The gels were scanned using a Bio-Rad GS-800 Densitometer and digital quantification was done using ImageJ software (ImageJ Software, U.S. National Institutes of Health, Bethesda, Maryland, USA).

\section{MMP2, MMP9, TFF3 and Muc2 expression analysis using qPCR}

The expression of matrix metalloproteinases 2 (MMP2) and 9 (MMP9) as well as mucin 2 (MUC2) and trefoil factor 3 (TFF3) was determined using GPCR to see if exogenous butyrate had an effect on the expression of these MMPs and the abundant secretory mucin MUC2 as well as its associated trefoil factor. All qPCR-experiments were carried out by a dedicated technician (BB) and are reported as detailed as possible according to the MIQE guidelines [21]. RNA was isolated from the tissue sample using TRI reagent (Sigma-Aldrich, the Netherlands) and treated with RNase-Free DNase Set (Qiagen). The purity of RNA was tested using Nanodrop Spectrophotometer (Thermo Scientific) by 260/280 absorbance (A260/A280) ratios, ranging from 1.89 to 2.02. Therefore, the purity of the isolated RNA was satisfactory for further studies. RNA of 750 ng was converted to DNA with sensifast cDNA Synthese kit (Bioline, London, UK). qPCR was performed on $10 \mathrm{ng}$ CDNA with $0.3 \mu \mathrm{M}$ primers in Sensimix SYBR \& Fluorescein Kit (Bioline, London, UK) using white 384-wells qPCR plate. Primer sequences are listed in Table 7.1. Reference genes included were glyceraldehyde-3-phosphate dehydrogenase (GAPDH) and B-actin. Reactions were run on the LightCycler480 (Roche). PCR conditions used were $10 \mathrm{~min}$ at $95^{\circ} \mathrm{C}$, followed by 40 amplification cycles of $15 \mathrm{~s}$ at $95^{\circ}-60^{\circ} \mathrm{C}-72^{\circ} \mathrm{C}$ followed by a melting curve to validate the amplifications. The cycle threshold $(\mathrm{Ct})$ value of each reference gene was obtained from qPCR analysis. The obtained $\mathrm{Ct}$ values were applied to evaluate the expression of the genes of interest. The mean $\mathrm{Ct}$ value of the reference genes ranged from 16 to 23 cycles, with HA-injection having the highest 
transcript levels in MMP9, and butyrin patch was associated with having the lowest transcript levels in TTF3. For analysis purposes, the level of MMP2 expression of the saline group was set at 1 and used as a control.

\section{Statistical analyses}

Statistical analysis was performed using Prism 5.0 for Mac (Graphpad software, San Diego, CA). Normality was tested using Kolmogorov-Smirnov. All continuous variables are presented as mean and standard error of the mean (SEM) and compared using student's t test or Mann Whitney $U$ when appropriate. Dichotomous variables were compared using the Chi-square test.

Table 7.1 Primer sequences used for qPCR experiments.

\begin{tabular}{ll}
\hline r-MMP9-F1 & AGCCGACGTCACTGTAACTG \\
r-MMP9-R1 & AACAGGCTGTACCCTTGGTC \\
r-MMP2-F1 & ACAACAGCTGTACCACCGAG \\
r-MMP2-R1 & GGACATAGCAGTCTCTGGGC \\
R-MUC-F1 & CGAAGTGAAGAGTGAGCACG \\
R-MUC-R1 & GATCCGGGTGGTATTCAGCA \\
R-Tff-F1 & GGCCTATCTCCAAGCCAATGT \\
R-Tff-R1 & TGCAGAGGTTTGAAGCACCA \\
GAPDH FW & GGAAGCTCACTGGCATGGC \\
GAPDH RV & CCTGCTTCACCACCTTCTTG \\
Beta-actin FW & GACAGGATGCAGAAGGAGATTACTG \\
Beta-actin RV & CCACCGATCCACACAGAGTACTT \\
\hline
\end{tabular}

\section{Results}

\section{Macroscopical results}

In experiment 1, two rats in the butyrin patch group died prior to completing follow-up due to faecal peritonitis. All animals in experiment 2 completed the 7-day follow up. In experiment 3, three rats (one in the HA-But group, three in the But group) were euthanized because they had reached humane endpoints, due to faecal peritonitis. An overview of the types of anastomotic leakage within each experimental group can be found in Figure 7.1a. Adhesions occurred in every experiment, and there were no significant differences between experiments (proximal versus distal anastomoses) nor within each experiment (Figure 7.1b). It became evident that animals receiving a patch (either butyrin eluting or placebo) had lower welfare scores and significant more weight 
loss compared to animals receiving enemas (Figure 7.1C), possibly due to an extended bowel proximal to the location of the patch upon sacrifice.

A

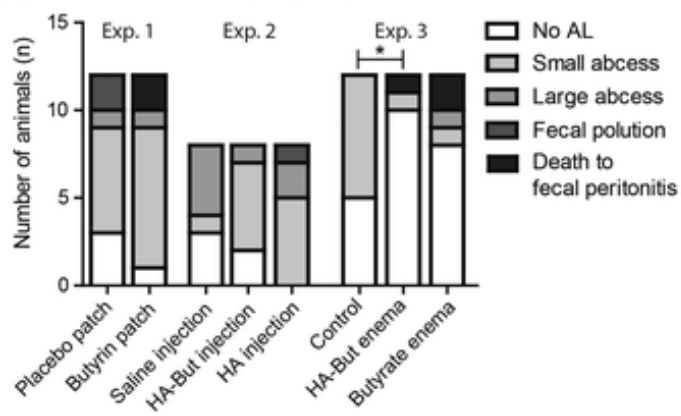

C

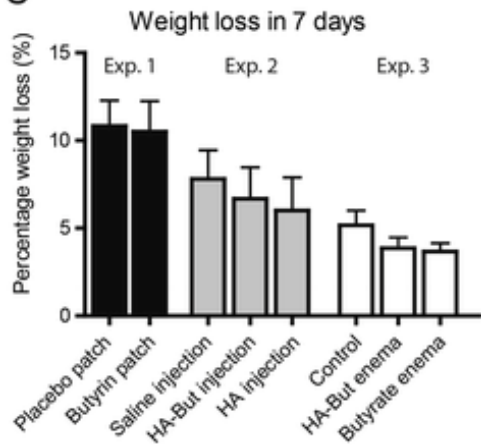

B

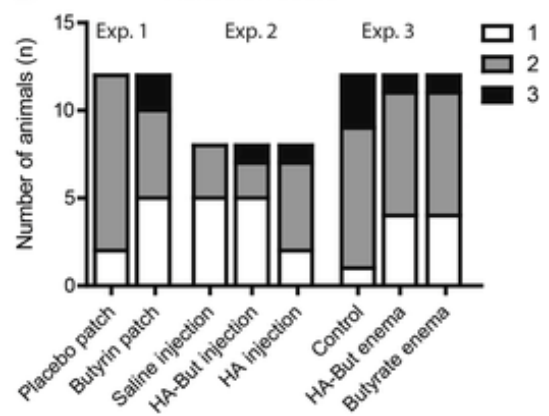

D

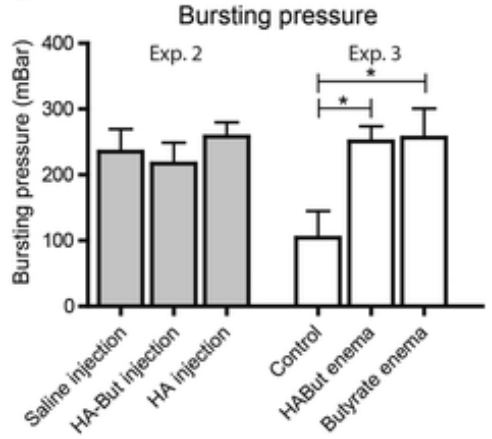

Figure 7.1 Butyrate-enriched enemas reduced AL in Exp. 3, no other butyrate-based intervention caused a decrease in AL rates (A). Adhesion scores did not differ significantly between groups in Exp. 1, 2 or 3 (B). Weight loss was most prominent in Exp. 1 where placement of the patches caused a sudden change in calibre of the colon; animals receiving enemas had the lowest percentage of weight loss but also received a different type of anastomosis compared to animals in Exp. 1 and 2 (distal vs proximal respectively) (C). The administration of butyrate enemas caused a significant higher bursting pressure of the anastomosis in Exp. 3 compared to the control group. No differences were found in Exp. 2 and in Exp. 1; no BP was measured due to porous, distended intestines

\section{Bursting pressure}

Bursting pressure (BP) was not measured during experiment 1 because of evident extended intestines in the majority of the rats at the place where the patches were placed. This abrupt change in luminal calibre made the dilated bowel very porous, disabling accurate BP measurements. In experiment 2, BP was measured and compared to a historical control group since the control group from experiment 3 received a distal 
anastomosis. No differences were found in experiment 2 between saline injections, HA injections and HA-But injections. In experiment 3, however, a significant difference could be found between the control group $(104.1 \pm 40.8)$ and HA-But $(250.7 \pm 23.1)$ and But enemas $(256.4 \pm 44.4, \mathrm{P}<0.05)$.

\section{Histology and collagen ratio}

Inflammatory parameters were scored as a surrogate marker of anastomotic healing, as indicated appropriately by a recent Delphi consensus method ${ }^{22}$. Histological analysis (Figure 7.2) only detected an increased inflammation in experiment 2 in the hyaluronan injection group $(2.18 \pm 0.22)$ compared to the control group $(3.27 \pm 0.27, \mathrm{P}<0.05)$. No other differences were found regarding wound healing. Picro Sirius red staining, which depicts the level of collagen maturity, of the anastomotic region showed comparable percentages of collagen for all groups (Table 7.2).

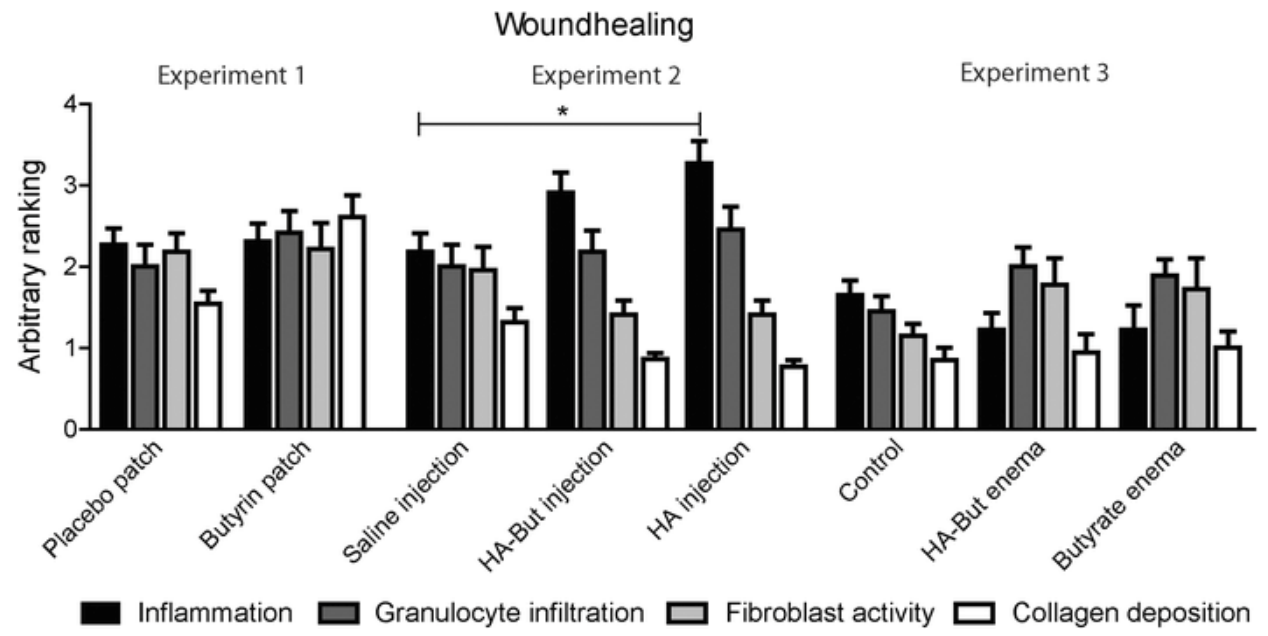

Figure 7.2 Histological analysis only detected an increased inflammation in experiment 2 in the hyaluronan injection group $(2.18 \pm 0.22)$ compared to the control group $(3.27 \pm 0.27, P<0.05)$. No other differences were found regarding wound healing. Values are mean ranking (S.E.M.).

\section{Pro-MMP9, MMP2 and MMP9 activities measured by zymography}

Zymography revealed no differences between MMP2 and MMP9 activity within each experiment between control and intervention groups (Figure 7.3). There was relatively large variability within the samples of each group as can be seen by the error bars/whiskers in the different graphs. In experiment 3 , the addition of hyaluronan to the 
butyrate enema did decrease the activity of pro-MMP9 $(40.6 \pm 8.2)$ compared to the butyrate enema alone $(102.6 \pm 26.9)$ and the control group $(114 \pm 20.9, \mathrm{P}=0.01)$.

Table 7.2 Total collagen and mature/immature collagen ratios.

\begin{tabular}{lcccc}
\hline Experiment 1 & Butyrin patch & Placebo patch & P-value & \\
\hline Collagen percentage (\%) & $32.25( \pm 2.69)$ & $28.64( \pm 2.00)$ & 0.239 & \\
Red/green ratio & $464.83( \pm 278.36)$ & $361.42( \pm 207,96)$ & 0.861 & \\
\hline Experiment 2 & Saline injection & HA-But injection & HA injection & P-value \\
\hline Collagen percentage (\%) & $53.22( \pm 2.04)$ & $45.29( \pm 4.51)$ & $46,50( \pm 4.83)$ & 0.361 \\
Red/green ratio & $66.89( \pm 16.76)$ & $39.66( \pm 7.88)$ & $95.64( \pm 44.43)$ & 0.340 \\
\hline Experiment 3 & Control & HA-But enema & Butyrate enema & P-value \\
\hline Collagen percentage $(\%)$ & $42.84( \pm 4.75)$ & $35.57( \pm 4.23)$ & $35.93( \pm 2.12)$ & 0.343 \\
Red/green ratio & $321.50( \pm 71.60)$ & $282.00( \pm 154.85)$ & $176.54( \pm 46.35)$ & 0.355 \\
\hline
\end{tabular}
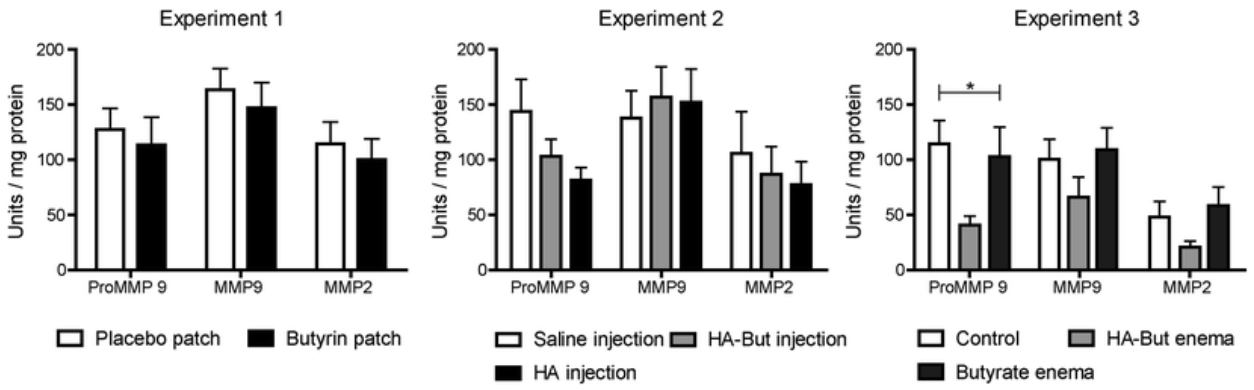

Figure 7.3 Zymography revealed no differences between MMP2 and MMP9 activity within each experiment between control and intervention groups. The addition of hyaluronan to the butyrate enema did decrease the activity of pro-MMP9 $(40.6 \pm 8.2)$ compared to the butyrate enema alone $(102.6 \pm 26.9)$ and the control group $(114 \pm 20.9)$ in experiment $3(P=0.01)$. Values are given in arbitrary units and data represent mean + S.E.M..

\section{qPCR showed no significant differences in the three experiments regarding gene expression}

In experiment 1, a trend was found in the expression of MMP2 between the group that received a butyrin patch $(0.35 \pm 44.4)$ and the placebo patch group $(1.14 \pm 0.34, \mathrm{P}<0.07$, Figure 7.4). The other tested matrix-metalloproteinase MMP9 also showed a trend between these two groups, $0.39 \pm 0.21$ versus $1.14 \pm 0.34$ respectively, $P<0.08$. No differences were found regarding MUC2 and TFF3. In experiments 2 and 3, no significant differences were found in gene expression between the intervention and control groups regarding all genes of interest. 

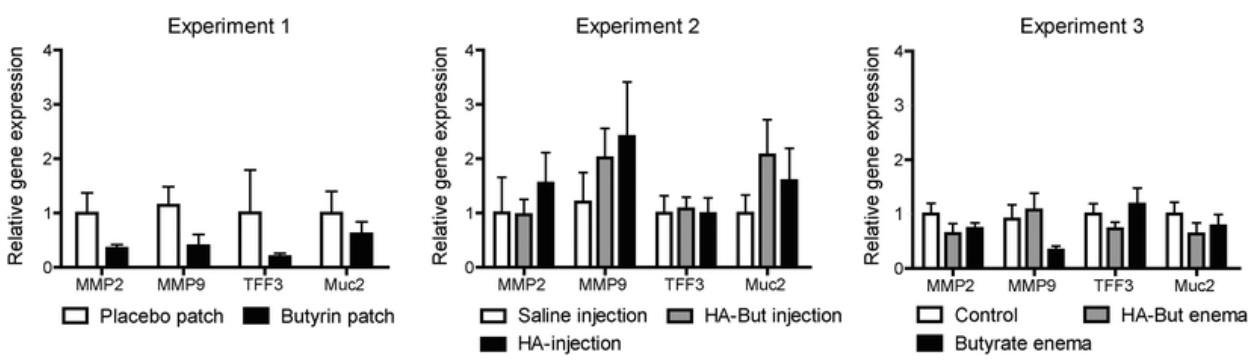

Figure 7.4 Overview of relative gene expression where the level of MMP2 expression of the saline group was set at 1 and used as a control. No significant differences were found in gene expression between the intervention and control groups regarding all genes of interest in the separate experiments.

\section{Discussion}

This study is the first study as far as we know that aims to improve butyrate supplementation in animal models to overcome the reservation of surgeons to optimize their patients with butyrate prior or during gastrointestinal surgery. We investigated different administration routes besides enemas that could enable surgeons to incorporate butyrate in the surgical procedure. Unfortunately, a single dosage of butyrate or a butyrin-eluting patch that we used in this study did not seem promising. Addition of hyaluronan to butyrate did not improve the effect of an enema on the healing of distal anastomoses. Unfortunately, this study did not lead to promising tools to transport butyrate to the proximal anastomotic site, but it did confirm that butyrate can lead to better anastomotic healing and this should be further investigated in the future.

Butyrate is known to have a critical mediating role in the colonic inflammatory response; for example, it can induce the differentiation of colonic regulatory $T$ cells and thereby ameliorate the development of colitis as shown by Furusawa et al. ${ }^{23}$. More recently, it has been shown that exogenous butyrate restoration improved intestinal epithelial cell junctional integrity, decreased apoptosis and mitigated graft-versus-host-disease after allogeneic bone marrow transplant ${ }^{24}$. Especially the restorative effect of butyrate on the epithelial integrity and, consequently, a decreased translocation of luminal contents are of great interest in the field of anastomotic leakage. It was often assumed that butyrate increases collagen synthesis and maturation and that this reduced the risk of anastomotic leakage ${ }^{6,7,8}$; however, with these new insights, it can be hypothesised that 
increased epithelial integrity leads to a lesser amount of (clinically relevant) anastomotic leakage.

As stated before, enemas seem to be a promising tool to deliver butyrate in the colon, especially in more distal anastomoses; however, it remains difficult to reach the same levels of butyrate in proximal anastomoses. In addition, butyrate is metabolized rapidly as soon as it enters the colonocyte via its active transport system. This could be the reason that experiment 2 was not successful; the amount of available butyrate by a single injection was simply not sufficient to cause any effect on the anastomotic site.

It was suggested that a prodrug of natural butyrate, tributyrin, could overcome the pharmacokinetic drawbacks of natural butyrate as a drug ${ }^{25}$. Since it was very difficult to incorporate butyrate in an eluting patch, butyrin was used instead, making sure that there were high concentrations available at the site of release. Unfortunately, the attachment of a patch into the colon caused extension of the bowel proximal to the location of the patch, indicating colonic stenosis. This effect of patches or fleeces has been previously described ${ }^{26}$; however, in that study, the authors used an external fleece and in experiment 1 , the film-like resorbable patches were attached intraluminally. This stenosis effect-clinically translatable to ileus-could be the explanation of why the animals in experiment 1 had lower welfare scores and lower weight compared to the other groups.

Hyaluronan is generally known to be associated with tissue repair and wound healing, and its concentration is high in healing tissues ${ }^{27}$. Its biological functions are the result of both its physicochemical properties and its biological interactions, depending on molecular weight ${ }^{28}$. Despite the logical hypothesis that the addition of hyaluronan to butyrate would enhance anastomotic healing, this was not observed in this study, possibly due to a low concentration or not having the appropriate molecular weight.

One of the limitations of this study - even if the newly tested approaches were successful - is the translation to the human setting. While butyrate can be administered as a rectal enema, this is rather invasive and not the preferred choice in drug administration. The risk of anastomotic dehiscence in a recent constructed anastomosis remains, which could be an explanation of the faecal peritonitis that was found in the enema groups in experiment 3. However, the very unpleasant odour and taste of butyrate makes oral administration extremely difficult. For this reason, Raso et al. have studied a derivative of butyrate, $\mathrm{N}$-(1-carbamoyl-2-phenyl-ethyl) butiramide (FBA) as a successful therapeutic alternative to butyrate, sharing a comparable efficacy, but a 
better palatability and compliance, unfortunately so far only in a rat mode ${ }^{29}$. Other articles that describe oral administration of butyrate were also designed as animal studies $^{30,31}$. Nevertheless, there are a few studies in which oral butyrate or its prodrug was given in humans and was considered safe and well tolerated ${ }^{32}$. The question remains if butyrate can be administered as a local agent at the site of the anastomosis, without potential harmful effects when it enters the systemic circulation. Van Beek et al. have recently demonstrated that splanchnic butyrate release was prevented in patients after colonic butyrate administration, indicating that rectal enemas even with high therapeutic dosage (up to $100 \mathrm{mmol} / \mathrm{L}$ ) of butyrate can be given safely ${ }^{33}$.

Conceivably new approaches may become available as nano-based drug delivery systems for encapsulation and release of drugs are currently being investigated in different fields of medicine ${ }^{34,35}$. Imaginably in the future, butyrate tablets will become standard perioperative treatment and due to nanotechnology, the release of butyrate will only take place at the site of interest, the colonic anastomosis.

In conclusion, butyrate can enhance the colonic anastomosis, making it less prone to lead to leakage. The most effective method thus far is by rectal enemas and the addition of hyaluronan did not ameliorate the effect of butyrate on the AL rate. Further research should be done to identify the optimal way of butyrate delivery to the anastomotic site where it can enhance anastomotic healing. 


\section{References}

1. Snijders HS, Wouters MWJM, van Leersum NJ, Kolfschoten NE, Henneman D, de Vries AC, et al. Metaanalysis of the risk for anastomotic leakage, the postoperative mortality caused by leakage in relation to the overall postoperative mortality. Eur J Surg Oncol 2012;38:1013-9.

2. Bakker IS, Grossmann I, Henneman D, Havenga K, Wiggers T. Risk factors for anastomotic leakage and leak-related mortality after colonic cancer surgery in a nationwide audit. Br J Surg 2014;101:424-32.

3. Nachiappan S, Askari A, Malietzis G, Giacometti M, White I, Jenkins JT, et al. The impact of anastomotic leak and its treatment on cancer recurrence and survival following elective colorectal cancer resection. World J Surg 2015;39(4):1052-8.

4. Morks AN, Havenga K, Ploeg RJ. Can intraluminal devices prevent or reduce colorectal anastomotic leakage: a review. World J Gastroenterol 2011;17:4461-9.

5. Daams F, Luyer M, Lange JF. Colorectal anastomotic leakage: aspects of prevention, detection and treatment. World J Gastroenterol 2012;19:2293-7.

6. Bloemen JG, Schreinemacher MH, de Bruine AP, Buurman WA, Bouvy ND, Dejong CH. Butyrate enemas improve intestinal anastomotic strength in a rat model. Dis Colon Rectum 2010;53:1069-75.

7. Netta S, Michalopoulos A, Apostolidis S, Paramythiotis D, Papavramidis T, Papadopoulos V, et al. Enhancement of colonic anastomotic strength in rats by short-chain fatty acids. Tech Coloproctol 2010; 14:53-55

8. Mathew AJ, Wann VC, Abraham DT, Jacob PM, Selvan BS, Ramakrishna BS, et al. The effect of butyrate on the healing of colonic anastomoses in rats. J Investig Surg 2010;23:101-4.

9. Pacheco RG, Esposito CC, Müller LCM, Castelo-Branco MTL, Quintella LP, Chagas VLA, et al. Use of butyrate or glutamine in enema solution reduces inflammation and fibrosis in experimental diversion colitis. World J Gastroenterol 2012;18:4278-87.

10. Knudsen KEB, Serena A, Canibe N, Juntunen KS. New insight into butyrate metabolism. Proc Nutr Soc 2003;62:81-6.

11. Cook S. Review article: short chain fatty acids in health and disease. Aliment Pharmacol Ther 1998; 12:499-507

12. Jung TH, Park JH, Jeon WM. Butyrate modulates bacterial adherence on LS174T human colorectal cells by stimulating mucin secretion and MAPK signaling pathway. Nutr Res Pract 2015;9:343-9.

13. Hamer HM, Jonkers D, Venema K, Vanhoutvin S, Troost FJ, Brummer R-J. Review article: the role of butyrate on colonic function. Aliment Pharmacol Ther 2008;27:104-19.

14. Bosmans JWAM, Jongen ACHM, Birchenough GMH, Nyström EEL, Gijbels MJJ, Derikx JPM, et al. Normal mucus composition is essential in the colonic anastomotic healing in mice [Internet]. uegw.congressonline.com. 2015. Available from: https://uegw.congress-online.com/guest/ID050c7f65a50e5d/ AbstractView?ABSID=10275

15. Price RD, Berry MG, Navsaria HA. Hyaluronic acid: the scientific and clinical evidence. J Plast Reconstr Aesthet Surg 2007;60:1110-9.

16. Sikkink CJJM. Applications of hyaluronan in abdominal surgery. 2011. Thesis Radboud University Nijmegen, the Netherlands. Available from: http://repository.ubn.ru.nl/bitstream/handle/2066/90827/ 90827.pdf?sequence=1

17. NC3Rs Reporting Guidelines Working Group. Animal research: reporting in vivo experiments: the ARRIVE guidelines. J Physiol 2010;588:2519-21.

18. van der Ham AC, Kort WJ, Weijma IM, van den Ingh HF, Jeekel J. Effect of fibrin sealant on the healing colonic anastomosis in the rat. Br J Surg 1991;78:49-53.

19. Vogels RRM, Bosmans JWAM, van Barneveld KWY, Verdoold V, van Rijn S, Gijbels MJJ et al (2015) A new poly(1,3-trimethylene carbonate) film provides effective adhesion reduction after major abdominal surgery in a rat model. Surgery 2015;157:1113-20.

20. Ågren MS, Andersen TL, Andersen L, Schiødt CB, Surve V, Andreassen TT, et al. Nonselective matrix metalloproteinase but not tumor necrosis factor- $\alpha$ inhibition effectively preserves the early critical colon anastomotic integrity. Int J Color Dis 2010;26:329-37. 
21. Bustin SA, Benes V, Garson JA, Hellemans J, Huggett J, Kubista M, et al. The MIQE guidelines: minimum information for publication of quantitative real-time PCR experiments. Clin Chem 2009;55:611-22.

22. Bosmans JWAM, Moossdorff M, Al-Taher M, van Beek L, Derikx JPM, Bouvy ND. International consensus statement regarding the use of animal models for research on anastomoses in the lower gastrointestinal tract. Int J Color Dis 2016;31:1021-30.

23. Furusawa Y, Obata Y, Fukuda S, Endo TA, Nakato G, Takahashi D, et al. Commensal microbe-derived butyrate induces the differentiation of colonic regulatory T cells. Nature 2013;504:446-50.

24. Mathewson ND, Jenq R, Mathew AV, Koenigsknecht M, Hanash A, Toubai T, et al. Gut microbiomederived metabolites modulate intestinal epithelial cell damage and mitigate graft-versus-host disease. Nat Immunol 2016;17:505-13.

25. Gaschott T, Steinhilber D, Milovic V, Stein J. Tributyrin, a stable and rapidly absorbed prodrug of butyric acid, enhances antiproliferative effects of dihydroxycholecalciferol in human colon cancer cells. J Nutr 2001;131:1839-43.

26. Schreinemacher MH, Bloemen JG, Heijden SJ, Gijbels MJ, Dejong CH, Bouvy ND. Collagen fleeces do not improve colonic anastomotic strength but increase bowel obstructions in an experimental rat model. Int J Color Dis 2011;26:729-35.

27. Litwiniuk M, Krejner A, Speyrer MS, Gauto AR, Grzela T. Hyaluronic acid in inflammation and tissue regeneration. Wounds 2016;28:78-88.

28. Maytin EV. Hyaluronan: more than just a wrinkle filler. Glycobiology 2016;26:553-9.

29. Mattace Raso G, Simeoli R, Russo R, lacono A, Santoro A, Paciello O, et al. Effects of sodium butyrate and its synthetic amide derivative on liver inflammation and glucose tolerance in an animal model of steatosis induced by high fat diet. PLoS One 2013;5;8(7):e68626.

30. Vieira ELM, Leonel AJ, Sad AP, Beltrão NRM, Costa TF, Ferreira TMR, et al. Oral administration of sodium butyrate attenuates inflammation and mucosal lesion in experimental acute ulcerative colitis. J Nutr Biochem 2012;23:430-6.

31. Russo R, De Caro C, Avagliano C, Cristiano C, La Rana G, Mattace Raso G, et al. Sodium butyrate and its synthetic amide derivative modulate nociceptive behaviors in mice. Pharmacol Res 2016;103:279-91.

32. Conley BA, Egorin MJ, Tait N, Rosen DM, Sausville EA, Dover G, et al. Phase I study of the orally administered butyrate prodrug, tributyrin, in patients with solid tumors. Clin Cancer Res 1998;4:629-34.

33. van der Beek CM, Bloemen JG, van den Broek MA, Lenaerts K, Venema K, Buurman WA, et al. Hepatic uptake of rectally administered butyrate prevents an increase in systemic butyrate concentrations in humans. J Nutr Am Soc Nutr 2015;145:2019-24.

34. Dolati S, Sadreddini S, Rostamzadeh D, Ahmadi M, Jadidi-Niaragh F, Yousefi M. Utilization of nanoparticle technology in rheumatoid arthritis treatment. Biomed Pharmacother 2016;80:30-41.

35. Fasehee H, Dinarvand R, Ghavamzadeh A, Esfandyari-Manesh M, Moradian H, Faghihi S, et al. Delivery of disulfiram into breast cancer cells using folate-receptor-targeted PLGA-PEG nanoparticles: in vitro and in vivo investigations. J Nanobiotechnol 2016114:32. 


\section{Chapter}

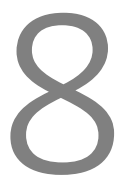

Functional mucous layer and healing of proximal colonic anastomoses in an experimental model

Joanna WAM Bosmans, Audrey CHM Jongen, G.M.H. Birchenough, E.E.L. Nyström, Marion JJ Gijbels, Joep PM Deriks, Nicole D Bouvy, G.C. Hansson

Br J Surg. 2017;104:619-630 


\section{Abstract}

Introduction

Anastomotic leakage $(\mathrm{AL})$ is the most dreaded complication after colorectal surgery, causing high morbidity and mortality. Mucus is a first line of defence against external factors in the gastrointestinal tract. In this study, the structural mucus protein Muc2 was depleted in genetically engineered mice and the effect on healing of colonic anastomoses studied in an experimental model.

Methods

Mice of different Muc2 genotypes were used in a proximal colonic AL model. Tissues were scored histologically for inflammation, bacterial translocation was determined by quantitative PCR of bacterial 165 ribosomal DNA, and epithelial cell damage was determined by assessing serum levels of intestinal fatty acid-binding protein.

Results

Of 22 Muc2-deficient (Muc2 ${ }^{-/}$) mice, 20 developed $\mathrm{AL}$, compared with seven of 22 control animals $(\mathrm{P}<0.001)$. Control mice showed normal healing, whereas Muc2 $2^{-/}$mice had more inflammation with less collagen deposition and neoangiogenesis. A tendency towards higher bacterial translocation was seen in mesenteric lymph nodes and spleen in Muc2 ${ }^{-/-}$mice. Intestinal fatty acid-binding protein levels were significantly higher in Muc2 ${ }^{-/-}$mice compared with controls $(P=0.011)$.

Conclusion

A functional mucous layer facilitates the healing of colonic anastomoses. 


\section{Introduction}

Anastomotic leakage (AL) is one of the most dreaded complications of colorectal surgery, and leads to high morbidity and mortality ${ }^{1,2}$. AL rates remain high, with reported rates ranging from 1 to almost 20 per cent, despite extensive research, improvement of surgical techniques and the development of fast-track programmes ${ }^{3,4}$. Identified risk factors for AL development, such as male sex, steroid use and location of the tumour, as well as concurrent disease and malnutrition, can help clinicians to determine which patients are at risk ${ }^{5,6}$. However, the underlying pathophysiological mechanisms for $\mathrm{AL}$ remain unclear ${ }^{7}$. A better insight to these mechanisms, and the factors promoting anastomotic healing, is needed to reduce rates of $\mathrm{AL}^{8}$.

The colon is protected by a two-phase mucous layer built around the gel-forming MUC2 mucin and a limited number of other components secreted from the goblet cells ${ }^{9,10}$. MUC2 mucin polymers form net-like sheets that, when layered on top of one another, form an inner colonic mucous layer that is impenetrable to bacteria ${ }^{11}$. This layer is about $50 \mu \mathrm{m}$ thick in mice and $200 \mu \mathrm{m}$ in humans, and is quickly renewed ${ }^{12}$. The inner layer is converted to a non-attached outer mucous layer, which is penetrable for colonic bacteria that use this layer as their habitat ${ }^{9,10}$. Muc2 gene-deficient mice lack a functional mucous layer, and have bacteria in direct contact with the epithelial cells in the intestine ${ }^{9}$. These mice develop colonic inflammation with a severity that depends on the bacterial flora in the animal housing facility.

Among the numerous factors contributing to healing of surgical anastomoses, the intestinal mucus system has been largely overlooked. This is despite the fact that numerous studies have shown that mucus is essential for protection of the epithelium from luminal challenge. For example, it was recently demonstrated that colonic ischemia resulted in detachment of mucus, which allowed bacteria to come into contact with the epithelium $^{13}$. When blood flow was restored, crypt goblet cells secreted stored mucus, which cleared the bacteria in contact with the epithelium, and re-established homeostasis. Thus, goblet cell mucous secretion plays a central role in regenerating a functional mucous layer that protects the host epithelium ${ }^{14}$.

Mucin secretion influences the capacity of the mucous layer to protect the colon, and altered secretion may result in different physiological consequences ${ }^{15}$. Barcelo and colleagues $^{16}$ demonstrated that mucin secretion can be modulated by luminal factors such as certain algal polysaccharides, uronic acids and short-chain fatty acids (SCFAs). Other factors influencing mucous secretion are prostaglandins and certain bacteria, such 
as Listeria monocytogenes and Akkermansia muciniphila ${ }^{17,18}$. In addition, prostaglandin (PG) E2, produced by the two isoforms of cyclo-oxygenase (COX) 1 and 2, can stimulate mucous secretion in both small intestine and proximal colon ex vivo ${ }^{19}$. Non-steroidal anti-inflammatory drugs (NSAIDs) inhibit COX enzymes, leading to a decrease in prostaglandin synthesis ${ }^{20}$. An association between the use of NSAIDs and AL has been described in both experimental and observational studies ${ }^{21-23}$, suggesting an interaction between prostaglandins and anastomotic healing. PGE2 could thus have a positive influence on anastomotic healing, mediated by its effect on mucous secretion.

In the present study, the protective role of a functional mucous layer on AL rates after colonic surgery in mice, and the influence of PGE2 administration on anastomotic wound healing were investigated.

\section{Methods}

\section{Animals}

All animal experiments were approved by the Gothenburg Animal Experiments Ethics Committee (permit 63-2014), and all experiments were performed in compliance with the directive on the protection of animals used for scientific purposes (2010/63/EU). This study followed the ARRIVE guidelines24; Appendix S8.1 (supporting information) provides more detailed information. Forty-four mice (mean(s.d.) weight $22 \cdot 3(3.8) \mathrm{g}$ ) of different genotypes (Muc2 ${ }^{-/-}$, Muc2 ${ }^{+/-}$and Muc2 $^{+/+}$) were matched for age (8-20 weeks) and sex when possible, in order to obtain an equal distribution within experimental groups (2 groups: Muc2 ${ }^{-/-}$versus control (Muc2 ${ }^{+/}$and $\mathrm{MuC2}^{+/+}$); 22 mice per group). Additionally, eight Muc2 ${ }^{-/-}$mice served as control animals in the quantitative PCR (qPCR) experiment for bacterial translocation, to distinguish between effects induced by surgery and the genotype. The mice had unlimited access to standard mouse chow and water. Welfare of the animals was assessed twice daily using extensive scoring according to Pommergaard and colleagues ${ }^{25}$. Postoperative pain relief with buprenorphine $0.1 \mathrm{mg} / \mathrm{kg}$ subcutaneously (Buprecare ${ }^{\circledR} ;$ AST Farma, Oudewater, The Netherlands) was administered when needed.

\section{Study design}

Muc2 $^{-/-}$, Muc2 ${ }^{+/-}$and wild-type (WT; Muc2 ${ }^{+/+}$) mice underwent laparotomy with colonic anastomosis and were killed on at day 3 after the operation. The heterozygous and WT mice were considered control animals $\left(\mathrm{Muc}^{+}\right)$, as both of these genotypes determine a 
normal mucous layer. The primary outcome was AL, defined by either faecal peritonitis or abscess formation at the anastomotic site. Macroscopic AL was diagnosed by two independent observers, who were blinded to the genotypes at the time of death.

\section{Model}

The model of AL used was that described previously by Komen and co-workers ${ }^{26}$ and subsequently adapted by Reisinger et al. ${ }^{27}$ to obtain a model that resembles clinical practice. In this model, mice undergo anaesthesia with isoflurane and receive pain treatment with buprenorphine $(0.1 \mathrm{mg} / \mathrm{kg}$ subcutaneously) before surgery in which a proximal colonic anastomosis is performed with seven interrupted extramucosal sutures (Prolene ${ }^{\circledR} 8 / 0$; Ethicon, Johnson \& Johnson, Somerville, New Jersey, USA), providing a leakage rate of 33.3 per cent. During surgery, the colon and caecum are kept moist with sterile saline. The body temperature of the mice is held constant at $37^{\circ} \mathrm{C}$ using a heat pad. The muscle layer and skin are closed using interrupted sutures (Vicryl ${ }^{\circledR} 4 / 0$ and Monocry $\mid{ }^{\circledR}$ Plus 4/0 respectively; both from Ethicon). After surgery, the mice receive 0.5 $\mathrm{ml}$ saline subcutaneously as fluid therapy. All surgical procedures were performed by a single investigator who was blinded to genotype at the time of surgery. The main outcome after surgery was macroscopic evaluation of the anastomosis, as follows: no $\mathrm{AL}$; small abscess, less than $0.5 \mathrm{~cm}^{3}$; large abscess, $0.5 \mathrm{~cm}^{3}$ or more; or faecal peritonitis.

\section{Tissue and blood sampling}

Histological assessment was performed on anastomotic tissue. To conserve the mucous layer, the anastomosis was dissected en bloc, leaving the sutures intact, and fixed in Carnoy solution (60 per cent methanol, 30 per cent chloroform, 10 per cent glacial acetic acid). Unaffected proximal and distal colonic tissues were obtained in the same manner, serving as control tissue. Mesenteric lymph nodes (MLNs) and spleen were snap-frozen in liquid nitrogen for further analysis. Blood samples were taken by intracardial puncture at time of animal killing, collected in EDTA vacuum tubes (BD Vacutainer ${ }^{\circledR} ;$ BD, Stockholm, Sweden) and kept on ice. Blood samples were centrifuged at 4000 r.p.m., at $4^{\circ} \mathrm{C}$ for 15 minutes. Plasma was stored immediately in aliquots at $-80^{\circ}$ until analysis.

\section{Measurements of mucous layer thickness}

To evaluate whether mucus was present at the anastomotic site of control animals, measurements of mucus were performed as described previously ${ }^{28}$, with some modifications. Briefly, unflushed proximal colon was opened longitudinally after removal of the mesenteric border. The tissue was pinned down on a silica gel plate with the 
luminal side facing upwards. Pellet material was gently removed and the mucus was visualized by adding charcoal particles on top of the mucus. The thickness of the mucous layer was then determined by measuring the distance between the mucous surface and the epithelial surface using a micropipette viewed through a stereomicroscope (Leica MZ12; Leica Microsystems, Heerbrugg, Switzer- land). Mucus was measured directly at the anastomotic site. Unaffected tissue was used for control measurements. The tissue was submerged in oxygenated Kreb's solution at all times. As Muc2 ${ }^{-/-}$mice do not have a functional mucous layer, this could not be measured in these animals ${ }^{29}$.

\section{Histological analysis}

Tissue samples were embedded in paraffin and cut in $4-\mu \mathrm{m}$ sections. To evaluate the morphology of cells and glycoproteins in the colonic mucous layer, standard haematoxylin and eosin, and periodic acid-Schiff-Alcian Blue (PAS-AB) staining was performed. Specimens were scored based on inflammation, granulocyte infiltration, fibroblast activity and neoangiogenesis, according to the Ehrlich and Hunt numerical scale (0-4) as modified by Phillips et al. ${ }^{30}$.

Immunohistochemistry for Ki-67 (proliferation), cleaved caspase 3 (CC-3) (apoptosis) and Muc2 (to confirm the phenotype of the animals) was performed. In short, slides were deparaffinized in xylene and rehydrated in graded ethanol to distilled water. Antigen retrieval was performed using target retrieval solution (Dako, Glostrup, Denmark) at $95^{\circ} \mathrm{C}$ for $20 \mathrm{~min}$. Non-specific antibody binding was blocked using 5 per cent fetal calf serum in phosphate-buffered saline (PBS) (Ki-67) or 1 per cent bovine serum albumin (Asp175). Sections were then incubated with specific primary antibodies (Ki-67 clone Sp6, Thermo Fisher Scientific, Life Technologies, Bleiswijk, The Netherlands; CC-3 Asp175, Cell Signalling Technology, Leiden, The Netherlands; or anti-MUC2C3 (provided by the Mucin Biology Group)9). After washing, swine antirabbit IgG biotin-labelled antibody (Dako, Glostrup, Denmark) for Ki-67 and CC-3 staining, and fluorophore-conjugated CY3 antirabbit antibody (Life Technologies) for Muc2 staining were used as second antibodies. Nuclei were stained using (nickel) 3,3'-diaminobenzidine (DAB) or 4',6-diamidino- 2-phenylindole (DAPI). All staining was evaluated by two independent observers using microscopy; they were blinded to the genotype of the mice. Ki-67 expression was analysed using ImmunoRatio software ${ }^{31}$, which calculates the percentage of positively stained nuclei (DAB) in relation to the other nuclei (haematoxylin). All CC-3 positive cells in one tissue sample were counted and comparisons were made between control and anastomotic tissue. 


\section{ELISA for intestinal fatty acid-binding protein}

Intestinal fatty acid-binding protein (I-FABP) is a plasma marker of enterocyte damage, as these small cytosolic proteins are present in mature enterocytes at the tip of the villus and released into the circulation following loss of enterocyte membrane integrity ${ }^{32}$. Patients who developed AL after colorectal surgery were shown to have raised I-FABP plasma levels before the operation ${ }^{33}$. I-FABP was measured in plasma using a commercially available sandwich enzyme immunoassay (lower detection limit 0.061 ng/ml; Cloud-Clone, Houston, Texas, USA) according to manufacturer's protocol.

\section{Prostaglandin E2 supplementation}

Inhibition of COX has been shown to increase the risk of $A L$, an effect suggested to be PGE2-mediated ${ }^{27}$. To investigate whether PGE2 has a positive influence on anastomotic healing, mice received either vehicle (PBS) or $100 \mu \mathrm{g} / \mathrm{g}$ bodyweight of 16,16-dimethyl PGE2 (dmPGE2), a stable PGE2 analogue (Cayman Chemical, Ann Arbor, Michigan, USA), by twice-daily intraperitoneal injection. Both interventions started 1 day before surgery and continued until postoperative day (POD) 3, after which all mice were killed.

\section{Quantitative PCR for bacterial translocation}

Total DNA was extracted from snap-frozen MLN and spleen tissue using a combination of sodium dodecyl sulphate and proteolytic digestion with bead beating and phenol/chloroform DNA purification, as previously described ${ }^{34}$. Bead beating was performed using Lysing Matrix E tubes in a FastPrep-24TM instrument (MP Biomedicals, Thermo Fisher Scientific, Gothenburg, Sweden). DNA was precipitated using $0.2 \mathrm{~mol} / \mathrm{l}$ sodium chloride and isopropanol, then resuspended in $100 \mu$ Tris-EDTA buffer and quanti ed using a NanoDropTM ND-1000 spectrophotometer (Thermo Fisher Scientific). DNA extractions from tubes containing no tissue served as contamination controls. Purified and quantified 16S DNA from Escherichia coli was used as a standard. Initially, bacterial ribosomal DNA (rDNA) was enriched from host DNA by limited-cycle (LC) PCR amplification of 16S rDNA using the universal 16S rDNA primer pair $27 \mathrm{~F}$ (AGAGTTTGATCMTGGCTCAG) and 1492R (CGGTTACCTTGTTACGACTT). Briefly, 50- $\mu$ I PCR mixtures containing 480 ng DNA, $0.2 \mu \mathrm{mol} / \mathrm{l}$ primers and HotStarTaq Plus Mastermix (Qiagen, Sollentuna, Sweden) were subjected to $5 \mathrm{~min}$ at $95^{\circ} \mathrm{C}$ and $16 \mathrm{cycles}$ of $94^{\circ} \mathrm{C}$ for $1 \mathrm{~min}, 55^{\circ} \mathrm{C}$ for $1 \mathrm{~min}$ and $72^{\circ} \mathrm{C}$ for $1-5 \mathrm{~min}$, followed by $10 \mathrm{~min}$ at $72^{\circ} \mathrm{C}$. Sample, standard and control LC-PCRs were then compared by qPCR using the $16 \mathrm{~S}$ rDNA primer pair $926 \mathrm{~F}$ (AAACTCAAAKGAATTGACGG) and 1062R (CTCACRRCACGAGCTGAC). In brief, 20- $\mu$ l qPCR mixtures were prepared using $2 \mu \mathrm{LCC}$ PCR mixture, $0 \cdot 3 \mu \mathrm{mol} / \mathrm{l}$ primers and SSoFastTM 
EvaGreen ${ }^{\circledR}$ Supermix (Bio-Rad, Sundbyberg, Sweden) and subjected to $95^{\circ} \mathrm{C}$ for $5 \mathrm{~min}$, then 30 cycles of $95^{\circ} \mathrm{C}$ for $15 \mathrm{~s}, 61.5^{\circ} \mathrm{C}$ for $15 \mathrm{~s}$ and $72^{\circ} \mathrm{C}$ for $20 \mathrm{~s}$, with EvaGreen ${ }^{\circledR}$ fluorescence measured at the final step of each cycle. qPCR thermocycling and fluorescence measurement was performed on a CFX96TM instrument (Bio-Rad). Sample amplification curves were compared with contamination control curves, and samples were considered 16S-positive if they amplified before controls. Sample $16 \mathrm{~S}$ was quantified using a standard curve generated from standard qPCR reactions.

\section{Statistical analysis}

Statistical analysis was performed using GraphPad Prism ${ }^{\circledR} 5.0$ for Mac (GraphPad Software, San Diego, California, USA). Normality was tested using the Kolmogorov Smirnov test. All continuous variables are presented as mean(s.d.) and compared using Student's $t$ test, the Mann-Whitney $U$ test, ANOVA or the Kruskal-Wallis test as appropriate. Dichotomous variables were compared using the $\chi 2$ test.

\section{Results}

\section{Anastomotic leakage rate is significantly higher in Muc2-deficient mice}

All mice $(n=44)$ completed follow-up of 3 days. After killing, the abdomen was reopened and the anastomotic site evaluated. Evaluation showed a wide range from normal healing/no AL to small and large abscesses, and even faecal peritonitis (Figure 8.1A-C). Muc2 $^{-/-}$mice had AL more frequently (score greater than 2) compared with control animals (20 of 22 versus 7 of 22 respectively; $P<0.001$ ) (Figure 8.2A). Three animals in the $\mathrm{Muc2}^{-/-}$group suffered from faecal peritonitis, whereas none of the control animals showed any sign of peritonitis. Further, both large ( 8 versus 1 in the control group) and small (9 versus 6 respectively) abscesses were found more frequently in Muc2 ${ }^{-/-}$mice. Bodyweight was similar at baseline in the two experimental groups, and remained so over time (Figure 8.2B). A significant decrease in welfare score was observed in Muc2 ${ }^{-1-}$ mice from POD 1, with maximum effect at POD $3(P<0.001)$ (Figure 8.2C). 


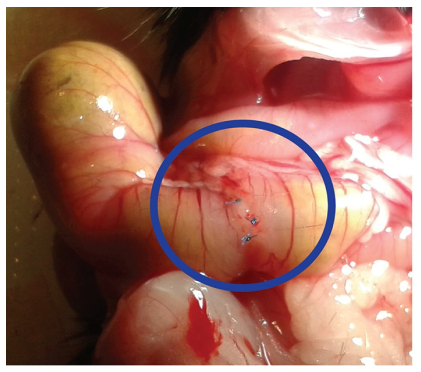

A No anastomotic leakage

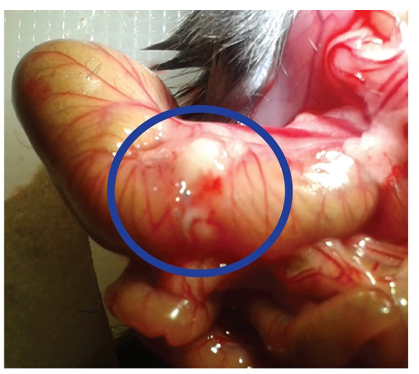

B Abscess

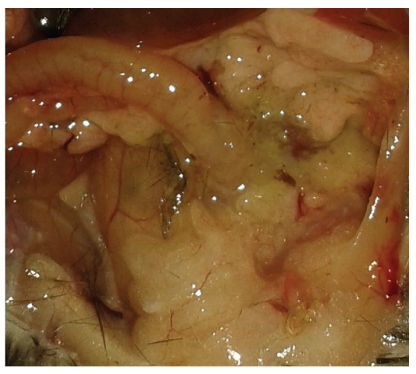

C Faecal peritonitis

Figure 8.1 Evaluation of the anastomosis: A) no anastomotic leakage, B) abscess (either small, less than $0.5 \mathrm{~cm}^{3}$, or large, $0.5 \mathrm{~cm}^{3}$ or more), C) faecal peritonitis.

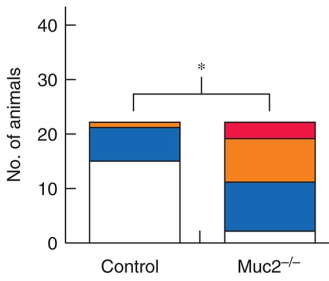

A AL rate per genotype

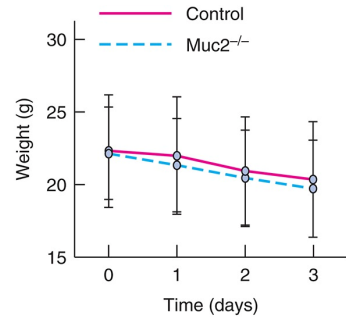

B Bodyweight per genotype

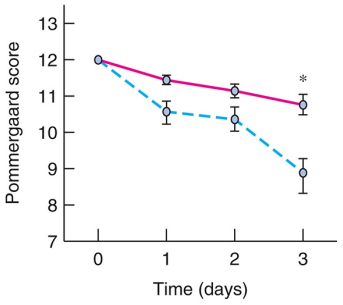

C Welfare score per genotype

Figure 8.2 A) $\mathrm{Muc2}^{-/-}$mice showed more frequent anastomotic leakage (AL) (score greater than 2; 20 of 22 mice) compared with control animals (7 of 22). ${ }^{*} P<0.001$ ( $\chi 2$ test). B) Mean(s.d.) bodyweight was similar at baseline in the two experimental groups and did not differ over time. C) A significant decrease in mean(s.d.) Pommergaard welfare score was seen in Muc $2^{-/}$mice from the first day after surgery, with maximum effect on day $3(8 \cdot 80(1.93)$ versus $10.76(1 \cdot 30)$ in control mice; ${ }^{*} P<0 \cdot 001,2$ - way ANOVA with Bonferroni post hoc test (time)).

\section{Mucus is present at the anastomotic site of control animals}

The mucous layer was visualized by the addition of charcoal and its thickness was measured by means of a glass capillary attached to micrometer, observed via a stereomicroscope (Figure 8.3A). A mucous layer was observed in Muc2 ${ }^{+}$animals at the site of anastomosis as well as in the proximal and distal colonic tissues (Figure 8.3B). In the proximal colon, the mean mucous layer thickness was greatest between folds $(238(17) \mu \mathrm{m})$ and lowest on top of the folds $(71(25) \mu \mathrm{m})$. Mean thickness of the mucous layer at the anastomotic site was 119(65) $\mu \mathrm{m}$. In the control group, no significant difference was found in mucous layer thickness between heterozygous $\left(\mathrm{Muc2}^{+/-}\right.$) and WT $\left(\mathrm{Muc2}^{+/+}\right.$) mice, or between mice that had AL and those that did not. As Muc2 deficient mice lack the structural component of intestinal mucus and therefore lack a 
defined mucous layer, measurement of the mucous layer in $\mathrm{Muc2}^{-/-}$mice was not feasible.

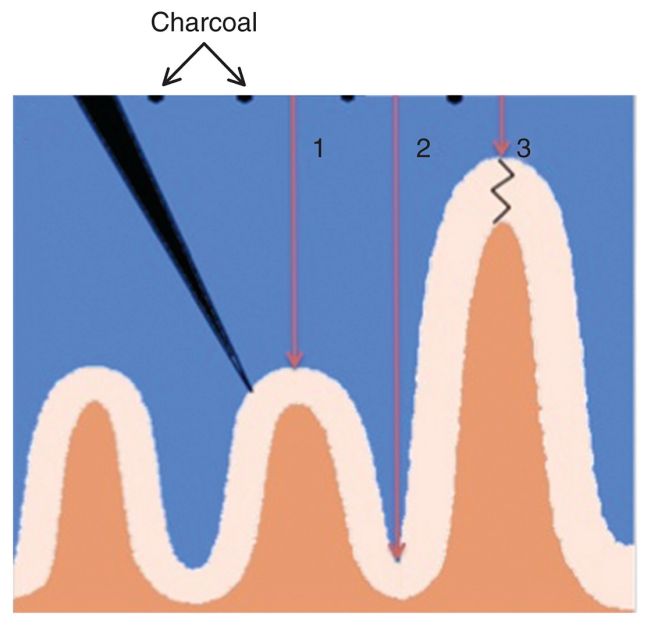

A Measurement of mucous layer

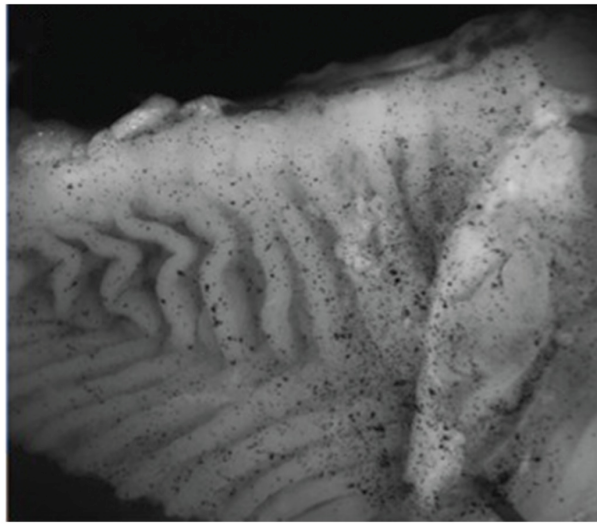

B Mucous layer in control animals

Figure 8.3 A) Adding charcoal on the sample enables the thickness of the mucous layer to be measured. Mucous layer thickness is defined as the distance between the charcoal particles and the tissue, and was measured on top of colonic folds, between folds and at the anastomotic site. B) A mucous layer was observed in Muc2+ animals, at the site of anastomosis as well as in the proximal and distal colonic tissues.

\section{Histological analysis showed more inflammation in Muc2-deficient mice}

Muc2 $^{-/-}$mice showed a tendency for more leucocyte infiltration, and less collagen deposition and neoangiogenesis at killing on POD 3 compared with Muc2 ${ }^{+}$animals (Figure 8.4A). In addition, continuation of the intestinal tissue was evident in the case of normal anastomotic healing, whereas AL caused disruption or dehiscence (Figure 8.4B). There was no difference in proliferation determined by Ki-67 staining between Muc2 ${ }^{-/-}$ and control mice at the serosal tissue of the anastomosis or in the enterocytes (Figure $8.4 C, D)$. CC-3 staining showed no differences in apoptosis between Muc2 $2^{-/-}$and control mice (Figure 8.4E,F).

A normal inner mucous layer, as shown by PAS-AB staining, was clearly observed in the Muc2 $^{+}$control mice, but was absent in Muc2 $^{-/-}$mice (Figure 8.5A,B). In addition, goblet cells in Muc2 $^{-/-}$mice showed only PAS-positive staining, whereas those from control animals also had positive $A B$ staining. Immunohistochemistry revealed the presence of 
Muc2-positive goblet cells in control animals, but in $\mathrm{Muc2}^{-/-}$mice there was no expression of Muc2, indicating no Muc2-positive goblet cells (Figure 8.5C,D).

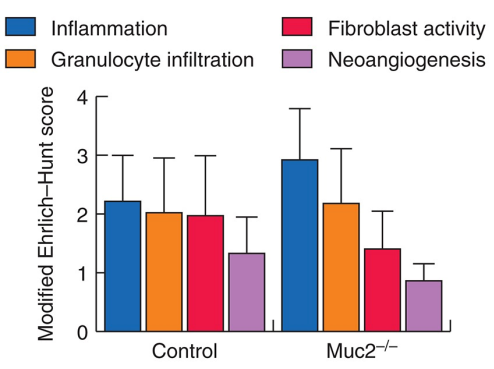

A Wound healing on day 3

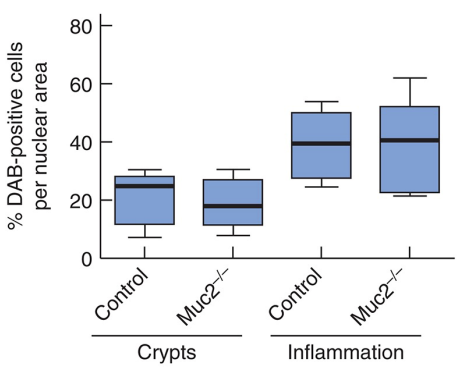

C Cell proliferation (Ki-67)

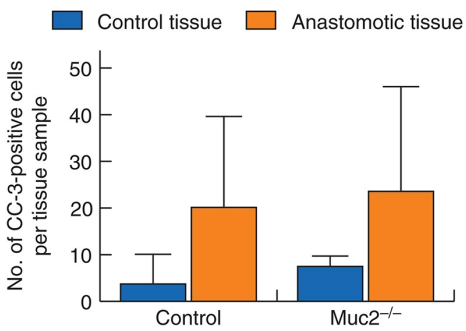

E Apoptosis (CC-3)
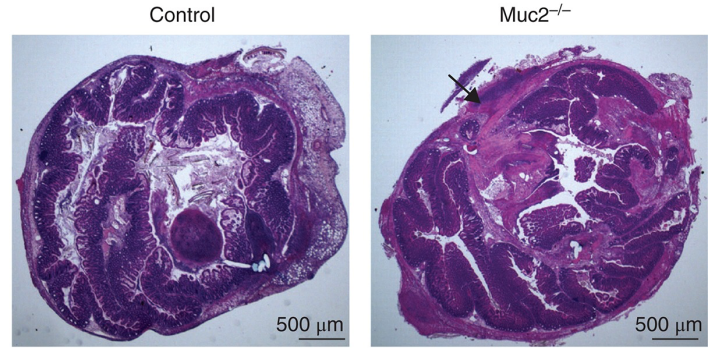

B Haematoxylin and eosin stain for anastomotic healing
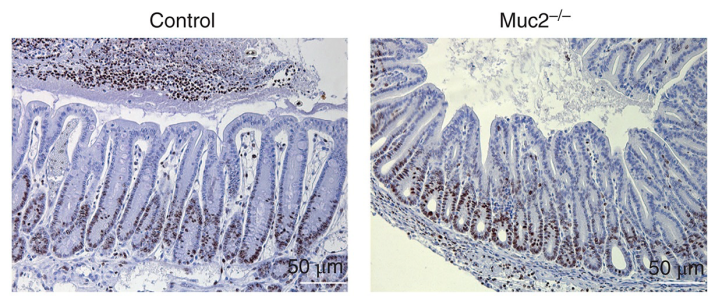

D Ki-67 staining by DAB
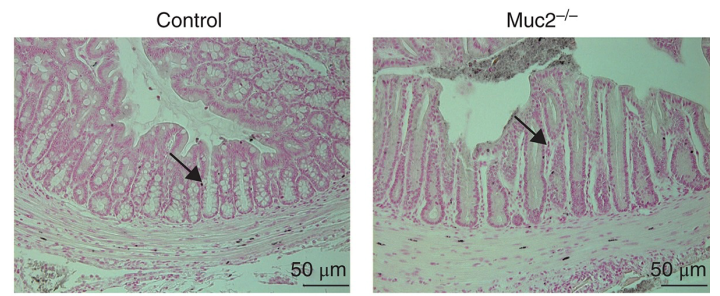

F CC-3 staining by DAB

Figure $8.4 \quad$ A) Inflammatory parameters scored on day 3 after surgery did not differ significantly between experimental groups. Values are mean(s.d.). B) In Muc2 $^{+}$animals with normal anastomotic healing there was continuation of the intestinal tissue, whereas anastomotic leakage in Muc2 $2^{-/-}$ mice caused disruption or dehiscence (arrows) (haematoxylin and eosin stain). C,D) There was no difference in cell proliferation measured by $\mathrm{Ki}$ - 67 staining with 3,3' - diaminobenzidine (DAB) between $\mathrm{Muc}^{-/-}$and control mice. Values are median, interquartile range and range. E,F) DAB staining for cleaved caspase (CC) 3 indicated no difference in apoptosis (arrows) between Muc2 $^{-/-}$and control mice. Values are mean(s.d.) 


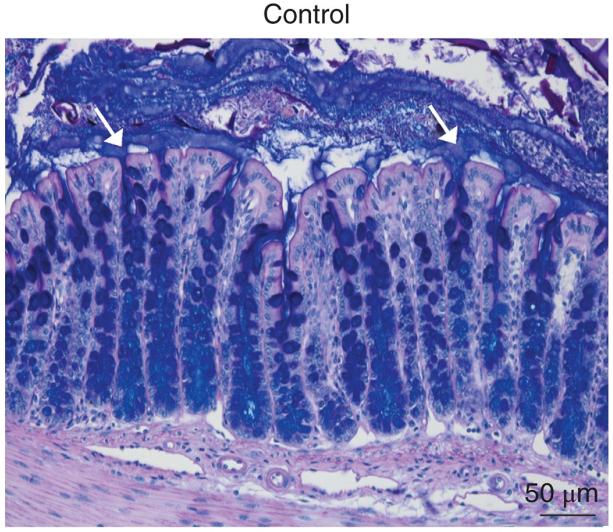

A PAS-AB staining in control

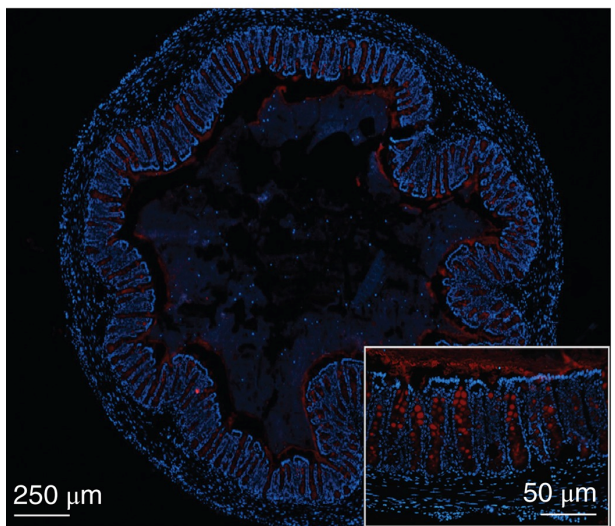

C Staining of Muc2 $^{+}$goblet cells in control

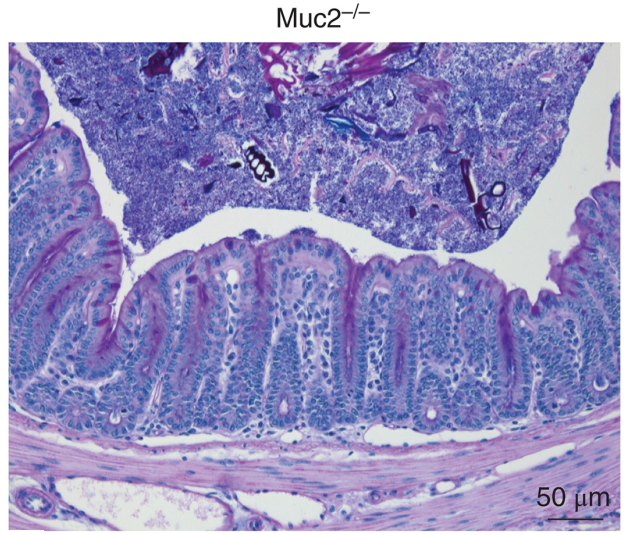

B PAS-AB staining in $\mathrm{Muc2}^{-/-}$animal

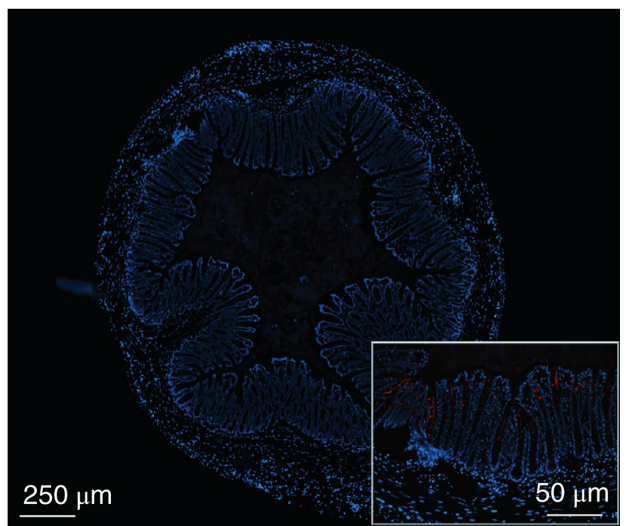

D Absence of Muc2 expression in Muc2 $^{-/-}$mouse

Figure 8.5 A,B) A normal inner mucous layer, as shown by periodic acid-Schiff-Alcian Blue (PAS - AB) staining, was clearly observed in the Muc2 $2^{+}$control mice (arrows), but was absent in Muc2 ${ }^{-/-}$ animals. C,D) Immunohistochemistry revealed the presence of Muc2 - positive goblet cells in control animals, but in Muc2 ${ }^{-/-}$mice there was no expression of Muc2, indicating no Muc2 - positive goblet cells. The minimal staining found in $\mathrm{Muc2}^{-/-}$is attributed to slight cross - reactivity of the anti - MUC2C3 antiserum with the mouse Fcgbp protein (Fc fragment of IgG - binding protein).

\section{Epithelial cells were damaged in Muc2-deficient mice}

When enterocytes are damaged they leak one of their main cytosolic proteins, I-FABP. Hence, measurement of I-FABP in plasma gives an estimate of intestinal tissue damage. Muc2 $^{-/-}$mice showed significantly higher plasma levels of I-FABP compared with control 
animals $(3.88(2.63)$ versus $1.82(1.83) \mathrm{ng} / \mathrm{ml}$ respectively; $\mathrm{P}=0.011)$ (Figure $8.6 \mathrm{~A}$ ), indicating greater enterocyte damage in the $\mathrm{Muc}^{-/-}$mice.

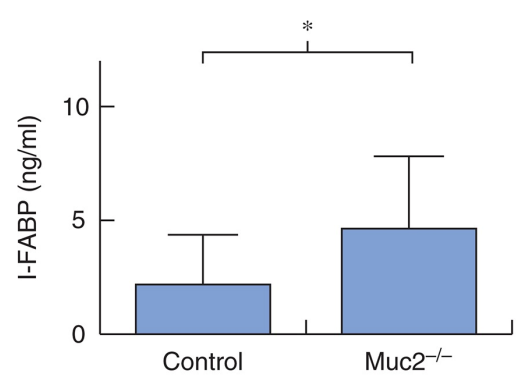

A Intestinal fatty acid-binding protein

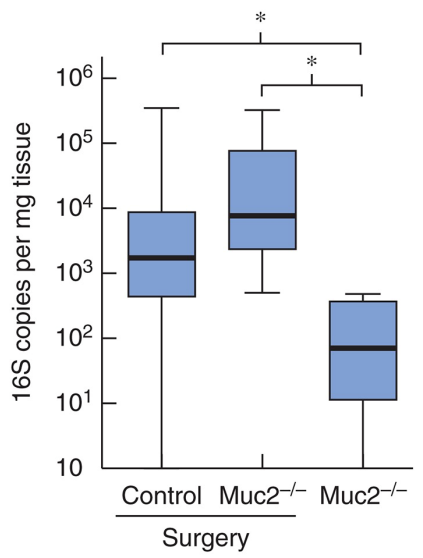

C Bacterial translocation to mesenteric lymph node

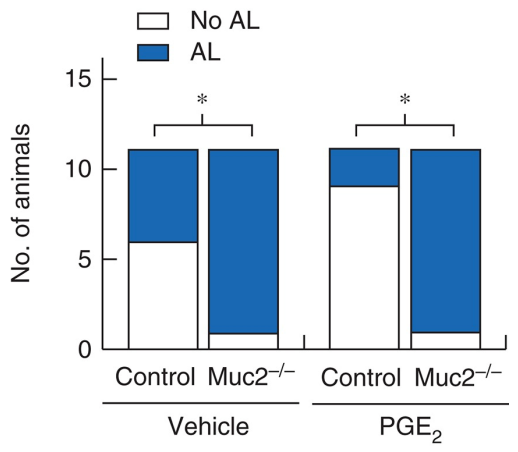

$B$ Effects of $\mathrm{PGE}_{2}$ supplementation

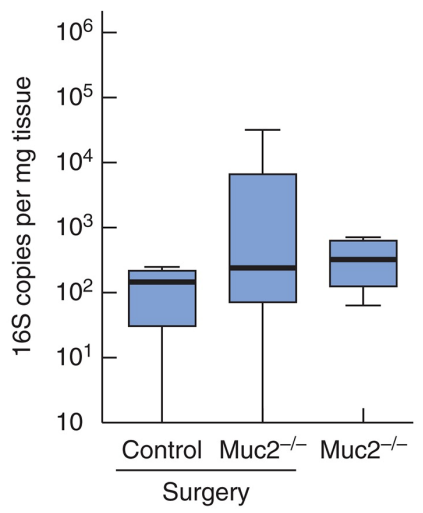

D Bacterial translocation to spleen

Figure 8.6 A) The concentration of intestinal fatty acid - binding protein (I - FABP) was significantly increased in $\mathrm{Muc2}^{-/-}$mice compared with that in control animals (mean(s.d.) 3.88(2.63) versus $1.82(1.83) \mathrm{ng} / \mathrm{ml}$ respectively), indicating more epithelial damage. ${ }^{*} \mathrm{P}=0.011$ (Student's t test). B) Following prostaglandin (PG) E2 supplementation, there was no reduction in the anastomotic leakage (AL) rate for $\mathrm{Muc2^{-/- }}$ mice (10 of 11 animals for both vehicle and PGE2), and the reduction in the $A L$ rate in control animals was not significant $(P=0.362$, Student's t test per experiment as well as 2 - way ANOVA with post hoc testing). ${ }^{*} P<0.001$. C) Bacterial translocation to the mesenteric lymph node was present in both control and $\mathrm{Muc2}^{-/-}$animals that underwent surgery, but not in $\mathrm{Muc2}^{-/-}$mice that had no operation. ${ }^{*} \mathrm{P}<0.050$ (Kruskal-Wallis test). D) No differences were found between experimental groups in bacterial translocation to the spleen. C,D) Box - and - whisker plots show values for median, interquartile range and range 


\section{PGE2 administration did not reduce anastomotic leakage in this model}

dmPGE2 was administered 1 day before surgery and on every postoperative day until the animals were killed (day 3 ). With the protocol and doses used, no reduction in the rate of $\mathrm{AL}$ was observed in Muc2 $2^{-/-}$animals (10 of 11 animals for both vehicle and PGE2). The same was true for control animals ( $A L$ in 5 of 11 for vehicle versus 2 of 11 for $\mathrm{PGE2}$; $\mathrm{P}=0.362$ ) (Figure 8.6B). Within the control group, no difference was found in $\mathrm{AL}$ rate between heterozygous (Muc2 ${ }^{+-}$) and WT mice.

\section{Bacterial translocation in control and Muc2-deficient mice that had surgery}

Bacterial 16S rDNA was quantified from MLN and spleen tissue from control and Muc2 ${ }^{-/-}$ mice that underwent surgery, and from Muc2 ${ }^{-/-}$mice that had no surgical intervention. The MLN $16 \mathrm{~S}$ load in both groups of mice having surgery was higher than that in the group that did not, indicating that the surgical procedure did cause increased bacterial translocation to the intestinal lymphatics (Figure 8.6C). No significant difference was detected between control and Muc2 ${ }^{-/-}$mice, although the median $16 \mathrm{~S}$ load was 4-4 times lower in control mice compared with $\mathrm{Muc2}^{-/-}$mice. Spleen load was similar in the three groups, with approximately 100 16S rDNA copies per mg tissue detected in most animals (Figure 8.6D). However, three of 11 mice in the Muc2 $2^{-/-}$surgery group had more than $10416 \mathrm{~S}$ copies/mg, indicating that more bacteria had penetrated the systemic tissue in a subgroup of these animals. Thus, the surgical procedure increased translocation of bacteria from the intestine, and Muc2 deficiency resulted in a tendency towards higher systemic bacterial load.

\section{Discussion}

The incidence of AL has remained high over the years, despite extensive research, the introduction of new surgical techniques and the construction of a diverting stoma in high-risk patients35. Many risk factors are being investigated, but the first line of defence in the gastrointestinal tract, the mucous layer, has been largely overlooked.

Mice deficient in the Muc2 gene (Muc2 ${ }^{-/-}$mice) lack a functional mucous layer, and were more prone to develop AL than matched $\mathrm{Muc2}^{+/-}$and $\mathrm{Muc2}^{+/+}$controls. Control animals had a leakage rate of 32 per cent (7 of 22 animals), in line with the model of Reisinger and colleagues ${ }^{27}$. In addition, $\mathrm{Muc2}^{-/-}$mice had lower welfare scores than control animals despite co-housing, and matching for age and sex where possible. It should be noted that Muc2 $2^{-/-}$mice develop spontaneous colitis, although this often 
remains asymptomatic in the animal facility ${ }^{36}$. The effects observed in Muc2 ${ }^{-/-}$mice are therefore ascribed to the development of $\mathrm{AL}$ rather than to the colitis phenotype. Weight loss did not differ significantly between $\mathrm{Muc2}^{-/-}$and control mice. However, the mice were killed only 3 days after surgery, and it is known that the difference in weight loss between animals with and those without leakage does not become evident until after 3 days ${ }^{25}$. At this time animals without AL start to gain weight, whereas mice with AL start to gain weight only after POD $5^{25}$. Not only did the Muc2 $2^{-/-}$mice show more clinical symptoms of $A L$ than control mice, they also had significantly higher I-FABP levels, indicating enterocyte damage and more bacterial translocation. The damaged epithelia and increased translocation could indicate that the mucous layer is important for reducing the number of bacteria that reach the vulnerable anastomosis site, and hence is important in the healing process. In line with this, there is accumulating evidence ${ }^{37,38}$ that bacteria are involved in the pathogenesis of $\mathrm{AL}$.

It was hypothesized that supplementation with $\mathrm{dmPGE2}$ would reduce the AL rate by increasing mucous secretion. However, dmPGE2 did not reduce the AL rate in either Muc2 ${ }^{-/-}$or control mice. It has been suggested that dmPGE2 can prevent AL when COX2 activity is decreased, induced either by drug treatment (COX inhibitors) or by knocking out the COX-2 gene ${ }^{27}$. In the present study, no difference in AL rate was observed following PGE2 administration, despite using a stable analogue of PGE2 in the same dosage that had an effect in a Cox2-deficient mouse model. Perhaps PGE2 is effective only when there is a severe deficiency of PGE2, which is not the case in Muc2 ${ }^{-/-}$mice. A higher dose of dmPGE2 induces adverse reactions in mice, with dose- and timedependent PGE2-induced diarrhoea ${ }^{39}$. In the present study, no diarrhoea was observed, indicating that the PGE2 dose used was safe.

In the present study, only anastomoses in the proximal colon, and not in other parts of the gastrointestinal tract, were investigated. Interestingly, Yauw and co-workers ${ }^{40}$ recently showed that diclofenac, a commonly used NSAID, caused AL in the ileum and proximal colon, but not in the distal colon. Furthermore, more recently, Rutegaird et al. ${ }^{41}$ found no increased risk of AL with NSAID use in patients undergoing anterior resection for rectal cancer. Previous associations between AL and NSAIDs were derived from pooled data for colorectal surgery, not solely rectal resections. Additionally, it has been shown by ex vivo analysis of the mucous layer that PGE2 caused significantly increased mucous secretion in the small intestine and less in the proximal colon, and none in the distal colon ${ }^{19}$. Moreover, in humans, membrane protein profiling has demonstrated distinctive regional differences in the colon ${ }^{42}$. These different observations suggest that the healing-promoting effect of PGE2 might differ along the gastrointestinal tract, and that this might also be the case for the healing-promoting effect of a functional mucous layer suggested here for the proximal colon. 
Potentially interesting factors that can influence the colonic mucous layer are certain bacteria or SCFAs. A frequent colonizer of the human colonic mucous layer is Akkermansia muciniphila, a mucin-degrading bacterium that is suggested to increase the thickness of the inner mucous layer ${ }^{18}$. The presence of $A$. muciniphila correlated with increased Muc2 gene expression, suggesting that A. muciniphila can enhance its own nutrient-rich environment ${ }^{43}$. Therefore, it can be hypothesized that supplementation with A. muciniphila or other bacteria before gastrointestinal surgery may boost mucous secretion, which can support anastomotic healing.

SCFAs from bacteria in the distal colon are important as the primary energy source for colonic epithelial cells, but also stimulate mucous secretion ${ }^{16}$. One of the most abundant SCFAs in the colon, butyrate, can strengthen distal anastomoses when given in enema form ${ }^{44}$, perhaps through stimulated mucous secretion ${ }^{16}$. Thus, commensal bacteria in the outer mucous layer of the distal colon may help to prevent AL in animal models by producing SCFAs. Furthermore, mucins have been suggested to have a trophic effect, as they are not readily digested and can be considered an important nutrient source for many intestinal organisms. Colonic mucus also contains trefoil factor (TFF) 3, a molecule known to have a trophic effect in the colon ${ }^{45}$. Mucus acts as a diffusion barrier, thereby hindering molecules such as TFF-3 from diffusing out quickly into the lumen, and increasing the local epithelial concentration. The colonic mucus and its main component MUC2 can thus be envisaged to have many effects that might be important for anastomotic healing.

When inflammation and cell proliferation were studied with immunohistochemistry, no differences were observed between the two experimental groups. This might be explained by the fact that mice were killed on day 3. It is known from other experiments ${ }^{26,27}$ that day 3 is early in the intestinal healing process and that potential differences become evident in later phases of healing. However, POD 3 was chosen for killing in the present study in order to prevent animal suffering.

Results from animal experiments cannot be translated directly to the human setting. Paradoxical to the observation that the thick mucous layer in the distal colon may be protective is that distal tumour location in patients is a known risk factor for the development of AL. For this reason, a diverting stoma is often constructed in clinical practice ${ }^{3,46}$. Although animal findings should be interpreted with caution, they can lead to new insights and provide possible interventions for the human setting. One important lesson is that the controlled ischemia necessary in surgery can be maintained for some time (up to $1 \mathrm{~h}$ ) and that the mucous layer recovers quickly after this time ${ }^{13}$. Owing to the slow biosynthesis of mucins, a second period of ischemia should be avoided ${ }^{47}$.

The mucous layer of the gastrointestinal tract has been largely overlooked in research on $\mathrm{AL}$, despite its function as a primary defence mechanism. In this study, mucus has been 
shown to play an essential role in normal anastomotic healing, and is probably also crucial in other types of gastrointestinal healing. Further research on anastomotic healing should focus on positively influencing the mucous layer, to promote better postoperative recovery. 


\section{References}

1. Bakker IS, Grossmann I, Henneman D, Havenga K, Wiggers T. Risk factors for anastomotic leakage and leak-related mortality after colonic cancer surgery in a nationwide audit. Br J Surg 2014;101:424-32.

2. Nachiappan S, Askari A, Malietzis G, Giacometti M, White I, Jenkins JT, et al. The impact of anastomotic leak and its treatment on cancer recurrence and survival following elective colorectal cancer resection. World J Surg 2015;39:1052-8.

3. Kingham TP, Pachter HL. Colonic anastomotic leak: risk factors, diagnosis, and treatment. J Am Coll Surg 2009;208:269-78.

4. Telem DA, Chin EH, Nguyen SQ, Divino CM. Risk factors for anastomotic leak following colorectal surgery: a case - control study. Arch Surg 2010;145:371-6.

5. Pommergaard HC, Gessler B, Burcharth J. Preoperative risk factors for anastomotic leakage after resection for colorectal cancer: a systematic review and meta-analysis. Colorectal Dis 2014;16:662-71.

6. Gessler B, Bock D, Pommergaard HC, Burcharth J, Rosenberg J, Angenete E. Risk factors for anastomotic dehiscence in colon cancer surgery - a population-based registry study. Int J Colorectal Dis 2016;31: 895-902.

7. Shogan BD, Carlisle EM, Alverdy JC, Umanskiy K. Do we really know why colorectal anastomoses leak? J Gastrointest Surg 2013;17:1698-707.

8. Bosmans JW, Moossdorff M, Al-Taher M, van Beek L, Derikx JP, Bouvy ND. International consensus statement regarding the use of animal models for research on anastomoses in the lower gastrointestinal tract. Int J Colorectal Dis 2016;31:1021-30.

9. Johansson ME, Phillipson M, Petersson J, Velcich A, Holm L, Hansson GC. The inner of the two Muc2 mucin- dependent mucus layers in colon is devoid of bacteria. Proc Natl Acad Sci U S A 2008;105: 15064-9.

10. JohanssonME,SjövallH,HanssonGC.Thegastro- intestinal mucus system in health and disease. Nat Rev Gastroenterol Hepatol 2013;10:352-61.

11. Ambort D, Johansson MEV, Gustafsson JK, Nilsson HE, Ermund A, Johansson BR, et al. Calcium and pHdependent packing and release of the gel-forming MUC2 mucin. Proc Natl Acad Sci U S A 2012;109: 5645-50.

12. Johansson ME. Fast renewal of the distal colonic mucus layers by the surface goblet cells as measured by in vivo labeling of mucin glycoproteins. PLoS One 2012;7:e41009.

13. Grootjans J, Hundscheid IH, Lenaerts K, Boonen B, Renes IB, Verheyen FK, et al. Ischaemia-induced mucus barrier loss and bacterial penetration are rapidly counteracted by increased goblet cell secretory activity in human and rat colon. Gut 2013;62:250-8.

14. Birchenough GM, Johansson ME, Gustafsson JK, Bergström JH, Hansson GC. New developments in goblet cell mucus secretion and function. Mucosal Immunol 2015;8:712-9.

15. Smith AC, Podolsky DK. Colonic mucin glycoproteins in health and disease. Clin Gastroenterol 1986;15: 815-37.

16. Barcelo A, Claustre J, Moro F, Chayvialle JA, Cuber JC, Plaisancié P. Mucin secretion is modulated by luminal factors in the isolated vascularly perfused rat colon. Gut 2000;46:218-24.

17. Coconnier MH, Dlissi E, Robard M, Laboisse CL, Gaillard JL, Servin AL. Listeria monocytogenes stimulates mucus exocytosis in cultured human polarized mucosecreting intestinal cells through action of listeriolysin O. Infect Immun 1998;66:3673-81.

18. Everard A, Belzer C, Geurts L, Ouwerkerk JP, Druart C, Bindels LB, et al. Cross-talk between Akkermansia muciniphila and intestinal epithelium controls diet-induced obesity. Proc Natl Acad Sci U S A 2013;110: 9066-71.

19. Ermund A, Schütte A, Johansson MEV, Gustafsson JK, Hansson GC. Studies of mucus in mouse stomach, small intestine, and colon. I. Gastrointestinal mucus layers have different properties depending on location as well as over the Peyer's patches. Am J Physiol Gastrointest Liver Physiol 2013;305:G341-7.

20. Vane JR, Botting RM. Anti-in ammatory drugs and their mechanism of action. In amm Res 1998;47(Suppl 2): S78-87. 
21. Holte K, Andersen J, Jakobsen DH, Kehlet H. Cyclo-oxygenase 2 inhibitors and the risk of anastomotic leakage after fast-track colonic surgery. Br J Surg 2009;96:650-4.

22. Rushfeldt CF, Sveinbjørnsson B, Søreide K, Vonen B. Risk of anastomotic leakage with use of NSAIDs after gastrointestinal surgery. Int J Colorectal Dis 2011;26:1501-9.

23. de Hingh $\mathrm{IH}$, van Goor H, de Man BM, Lomme RM, Bleichrodt RP, Hendriks T. Selective cyclo-oxygenase 2 inhibition affects ileal but not colonic anastomotic healing in the early postoperative period. Br J Surg 2006;93:489-97.

24. Kilkenny C, Browne WJ, Cuthill IC, Emerson M, Altman DG. Improving bioscience research reporting: the ARRIVE guidelines for reporting animal research. PLoS Biol 2010;8:e1000412.

25. Pommergaard H-C, Achiam MP, Rosenberg J. Colon anastomotic leakage: improving the mouse model. Surg Today 2013;44:933-9.

26. Komen N, van der Wal H-C, Ditzel M, Kleinrensink G-J, Jeekel H, Lange JF. Colorectal anastomotic leakage: a new experimental model. J Surg Res 2009;155:7-12.

27. Reisinger KW, Schellekens DH, Bosmans JW, Boonen B, Hulsewé KW, Sastrowijoto P, et al. Cyclooxygenase-2 is essential for colorectal anastomotic healing. Ann Surg 2017;265(3):547-54.

28. Gustafsson JK, Ermund A, Johansson ME, Schütte A, Hansson GC, Sjövall H. An ex vivo method for studying mucus formation, properties, and thickness in human colonic biopsies and mouse small and large intestinal explants. Am J Physiol Gastrointest Liver Physiol 2012;302:G430-8.

29. Johansson ME, Gustafsson JK, Holmén-Larsson J, Jabbar KS, Xia L, Xu H, et al. Bacteria penetrate the normally impenetrable inner colon mucus layer in both murine colitis models and patients with ulcerative colitis. Gut 2014;63:281-91.

30. Phillips JD, Kim CS, Fonkalsrud EW, Zeng H, Dindar H. Effects of chronic corticosteroids and vitamin A on the healing of intestinal anastomoses. Am J Surg 1992;163:71-7.

31. Tuominen VJ, Ruotoistenmaki S, Viitanen A. ImmunoRatio: a publicly available web application for quantitative image analysis of estrogen receptor (ER), progesterone receptor (PR), and Ki-67. Breast Cancer Res 2010;12:R56.

32. Schellekens DH, Grootjans J, Dello SA, van Bijnen AA, van Dam RM, Dejong CH et al. Plasma intestinal fatty acid-binding protein levels correlate with morphologic epithelial intestinal damage in a human translational ischemia - reperfusion model. J Clin Gastroenterol 2014;48:253-60.

33. Reisinger KW, Poeze M, Hulsewé KW, van Acker BA, van Bijnen AA, Hoofwijk AG, et al. Accurate prediction of anastomotic leakage after colorectal surgery using plasma markers for intestinal damage and in ammation. J Am Coll Surg 2014;219:744-51.

34. Zoetendal EG, Heilig HG, Klaassens ES, Booijink CC, Kleerebezem M, Smidt H, et al. Isolation of DNA from bacterial samples of the human gastrointestinal tract. Nat Protoc 2006;1:870-3.

35. Daams F, Luyer M, Lange JF. Colorectal anastomotic leakage: aspects of prevention, detection and treatment. World J Gastroenterol 2013;19:2293-7.

36. Wenzel UA, Magnusson MK, Rydström A, Jonstrand C, Hengst J, Johansson ME, et al. Spontaneous colitis in Muc2-de cient mice re ects clinical and cellular features of active ulcerative colitis. PLoS One 2014;9: e100217.

37. Shogan BD, Belogortseva N, Luong PM, Zaborin A, Lax S, Bethel C, et al. Collagen degradation and MMP9 activation by Enterococcus faecalis contribute to intestinal anastomotic leak. Sci Transl Med 2015;7: 286 ra68.

38. Olivas AD, Shogan BD, Valuckaite V, Zaborin A, Belogortseva N, Musch M, et al. Intestinal tissues induce an SNP mutation in Pseudomonas aeruginosa that enhances its virulence: possible role in anastomotic leak. PLoS One 2012; 7:e44326.

39. Riviere PJ, Farmer SC, Burks TF, Porreca F. Prostaglandin E2-induced diarrhea in mice: importance of colonic secretion. J Pharmacol Exp Ther 1991;256:547-52.

40. Yauw ST, Lomme RM, van der Vijver RJ, Hendriks T, van Laarhoven KJ, van Goor H. Diclofenac causes anastomotic leakage in the proximal colon but not in the distal colon of the rat. Am J Surg 2015;210: 382-8.

41. Rutegård M, Westermark S, Kverneng Hultberg D, Haapamäki M, Matthiessen P, Rutegård J. Nonsteroidal anti-in ammatory drug use and risk of anastomotic leakage after anterior resection: a protocolbased study. Dig Surg 2016;33:129-35. 
42. Membrane protein profiling of human colon reveals distinct regional differences. Mol Cell Proteomics 2014;13:2277-87.

43. Ganesh BP, Klop eisch R, Loh G, Blaut M. Commensal Akkermansia muciniphila exacerbates gut in ammation in Salmonella typhimurium-infected gnotobiotic mice. J Am Coll Surg 2015;220:186-94.

44. Bloemen JG, Schreinemacher MH, deBruine AP, Buurman WA, Bouvy ND, Dejong CH. Butyrate enemas improve intestinal anastomotic strength in a rat model. Dis Colon Rectum 2010;53:1069-75.

45. Judd LM, Chalinor HV, Walduck A, Pavlic DI, Däbritz J, Dubeykovskaya Z, et al. TFF2 de ciency exacerbates weight loss and alters immune cell and cytokine pro les in DSS colitis, and this cannot be rescued by wildtype bone marrow. Am J Physiol Gastrointest Liver Physiol 2015;308:G12-24.

46. Shiomi $A$, Ito $M$, Maeda $K$, Kinugasa $Y$, Ota $M$, Yamaue $H$, et al. Effects of a diverting stoma on symptomatic anastomotic leakage after low anterior resection for rectal cancer: a propensity score matching analysis of 1014 consecutive patients. J Am Coll Surg 2015;220:186-94.

47. Johansson MEV, Hansson GC. The goblet cell: a key player in ischaemia-reperfusion injury. Gut 2013;62: 188-9. 


\section{Chapter}

The shift in microbial composition and diversity in a rat model of NSAID induced anastomotic leak can be attributed to surgical stress

Audrey CHM Jongen*, Simon TK Yauw*, Robin E Klabbers, Roger MLM Lomme, Nicole D Bouvy, Paul H Savelkoul, John Penders, Harry van Goor

* Contributed equally to this paper Submitted 


\section{Abstract}

\section{Background}

Growing evidence suggests a central role for the gut microbiome in the pathogenesis of anastomotic leakage. Nonsteroidal anti-inflammatory drugs (NSAIDs) have been recently identified as perioperative risk factor for $\mathrm{AL}$ and may also affect the microbiome.

Aim

The objective of this study was to explore the influence of anastomotic surgery and NSAID treatment on the microbiome composition of different bowel segments and the association with leak rates.

\section{Methods}

50 rats underwent intestinal resection and anastomosis construction in the ileum (IL), proximal colon (PC) or distal colon (DC). One PC group did not receive diclofenac, whereas all other groups did. Faecal samples collected from the anastomotic site on POD0 and POD3 were analyzed by 165 rRNA sequencing.

Results

More distally, the relative abundance of the Firmicutes phylum decreased, whereas the Bacteroidetes increased. Microbial diversity of the proximal and distal colon was significantly decreased on $\mathrm{POD} 3(\mathrm{P}=0.0025$ and $\mathrm{P}=0.007$ respectively) compared to PODO. Clear differences in relative abundance of several species could be observed between preoperative and postoperative samples, in all investigated segments. Surgery was the main contributing factor to these observed changes: it explained $75 \%$ of the variance in microbiota between PODO and POD3 in the ileum. Furthermore, analyses revealed no significant differences in alpha diversity metrics between leakage and nonleakage samples in the proximal and distal colon.

Conclusion

Surgical stress prompts a shift in microbial composition in all investigated segments. Microbial changes do not explain the increased risk for AL following NSAID treatment in this model. 


\section{Introduction}

Anastomotic leak $(\mathrm{AL})$ is the most feared complication following intestinal surgery. It is associated with high morbidity and mortality and occurs in $6-12 \%$ of patients after colorectal resection ${ }^{1,2}$. Leak rates have failed to decline over the past decades despite intensive research in this field, emphasizing the need for a better understanding of leak pathogenesis.

Several recent studies have reinforced the hypothesis that gut bacteria play a central role in the pathogenesis of $\mathrm{AL}$, by demonstrating a protective effect of antibiotics, and oral antibiotics in particular, against anastomotic leak ${ }^{3,4}$. It has been shown that multiple surgery-related factors, such as fasting, bowel preparation, antibiotics, surgical trauma and analgesics, can influence the microbiome ${ }^{5}$, and in turn, that microbial changes and increased bacterial virulence can disturb anastomotic healing ${ }^{6,7}$.

Since the past decade, nonsteroidal anti-inflammatory drug (NSAID) use has been associated with an increased risk of developing $A L$ in both human and experimental studies $^{8,9}$. Although the main hypotheses are that this is caused by COX2-inhibition or topical toxicity of drug metabolites, several studies also support a role for the microbiome in NSAID-induced leakage ${ }^{10-13}$. Ueijima et al. demonstrated that the presence of specific microbes is a prerequisite for the induction of small intestinal ulcers in rats treated with NSAIDs ${ }^{10}$. Another study provided evidence that NSAIDs also have a direct influence on the microbiota composition. Following injection with indomethacin, an overgrowth of $\mathrm{E}$. faecalis was observed in the rat small intestine, which resulted in the relative diminution of commensal microbes such as segmented filamentous bacteria $^{14}$. Interestingly, high collagenase producing strains of $\mathrm{E}$. faecalis have also been associated with $\mathrm{AL}$ in both experimental and clinical studies ${ }^{15}$. We have previously demonstrated that the use of the NSAID diclofenac causes leakage of anastomoses in the ileum and proximal colon in rats, but not in the distal colon ${ }^{16}$. These observed differences in AL may be explained by differences in microbiota, as this is an important discriminating factor between these segments ${ }^{17,18}$.

The cumulative evidence suggests that the microbiome of the gut may play an important role in the pathogenesis of $\mathrm{AL}$, and could also contribute to NSAID-induced intestinal complications. The aim of the present study is to capture the changes that occur in the composition of the rat microbiota in different intestinal segments as a result of anastomotic surgery and the administration of diclofenac, and to explore whether these changes can account for differences in diclofenac-induced leakage. 


\section{Materials and methods}

\section{Ethics}

This experiment was conducted according to the Dutch "Experiments on Animals Act" and European Federation of Laboratory Animal Science Associations guidelines and was approved by the institutional Animal Ethics Committee of the Radboud University.

\section{Animals}

Faecal samples were collected from 50 Male Wistar rats (Harlan, Horst, The Netherlands), housed under standard laboratory conditions with free access to food and water. Rats were accustomed to laboratory conditions for one week prior to the start of the experiment. Animals were weighed daily and were inspected for signs of reduced wellbeing twice daily during the experiment. Signs that were monitored included red eyes, nose, and/or fur, piloerection, aberrant behaviour, distended abdomen, and diarrhoea. Humane endpoints were defined; animals were euthanized if they showed signs of severe discomfort (e.g. weight loss $>20 \%$, distended abdomen or severely reduced activity).

\section{Study design}

The experiment was conducted as previously described ${ }^{16} .50$ rats underwent a $1 \mathrm{~cm}$ bowel resection followed by the construction of an anastomosis. Depending on the group randomization, resection and anastomosis construction occurred either in the ileum (IL), proximal colon (PC) or distal colon (DC), under strict aseptic conditions. No antibiotics were administered. Groups IL+ $(n=10), P C+(n=15)$ and $D C+(n=10)$ received diclofenac (3 $\mathrm{mg} / \mathrm{kg} /$ day) until sacrifice on post-operative day 3 (POD3), with the first dose administered 15 minutes prior to the operation. Rats in group PC- $(n=15)$ did not receive diclofenac.

On POD3 animals were euthanized by $\mathrm{CO} 2$ asphyxiation. After euthanization, a relaparotomy was performed and the anastomosis and abdomen were inspected for macroscopic signs of anastomotic leakage. Two investigators independently assessed the presence and extent of leak by means of an anastomotic leak severity score. Any differences in scores were resolved by consensus. A score of ' 0 ' constituted no signs of leakage, a score of ' 1 ' constituted anastomotic abscesses, a score of ' 2 ' represented free pus or large abscesses, and a score of ' 3 ' stood for faecal peritonitis or visible dehiscence $^{19}$. 


\section{Feces sample collection}

Faeces samples were collected from the resected segment (i.e. IL or PC or DC) during the initial operation on POD 0 (samples 'DO') and again after sacrifice on POD 3 (samples 'D3'). Samples were snap frozen in liquid nitrogen and stored at $-80^{\circ} \mathrm{C}$.

\section{DNA isolation}

DNA isolation was performed using a combination of repeated bead-beating and column-based purification as described previously ${ }^{20}$. Briefly, PSP lysis buffer (Stratec Molecular, Berlin, Germany) and approximately $50 \mathrm{mg}$ of frozen stool aliquots were added to a sterile vial containing $0.5 \mathrm{~g}$ of $0.1 \mathrm{~mm}$ zirconia/silica beads and 4 3.0-3.5 mm glass beads (BioSpec, Bartlesville, USA). The samples were homogenized in a MagNA Lyser instrument (Roche, Basel, Switzerland) in three cycles of 1 minute at a speed of $5500 \mathrm{rpm}$, interspersed with cooling on ice for one minute in between cycles. DNA isolation was continued using the PSP Spin Stool Kit (Stratec Molecular, Berlin, Germany) according to the manufacturer's instructions. DNA was finally eluted in $200 \mu$ l elution buffer.

\section{Sequencing}

Amplicon libraries and sequencing were performed according to previously published protocols $^{21}$. Briefly, the V4 region of the 16S rRNA gene was PCR amplified from each DNA sample in triplicate using the 515f/806r primer pair described previously ${ }^{21}$. Pooled amplicons from the triplicate reactions were purified using AMPure XP purification (Agencourt, Massachusetts, USA) according to the manufacturer's instructions and eluted in $25 \mu \mathrm{l} 1 \times$ low TE (10 mM Tris-HCl, $0.1 \mathrm{mM}$ EDTA, $\mathrm{pH}$ 8.0). Quantification of amplicons was subsequently performed by the Quant-iT PicoGreen dsDNA reagent kit (Invitrogen, New York, USA) using a Victor3 Multilabel Counter (Perkin Elmer, Waltham, USA). Amplicons were mixed in equimolar concentrations to ensure equal representation of each sample, and sequenced on an Illumina MiSeq instrument.

\section{Data analysis and statistics}

Filtering, denoising, removing of chimeric sequences and clustering of sequences in Operational Taxonomic Units (OTUs) at 97\% similarity was conducted using the LotuS pipeline (version 1.39) ${ }^{22}$. First, sequences with an average quality below 27, a read length below 170 bases, with one or more ambiguous bases, or containing homopolymer stretches of over 8 bases were discarded. Retained sequences were chimera filtered and clustered into OTUs using UPARSE23. Taxonomic annotation of 
OTUs was derived from RDP naïve Bayes classifier annotations (minimum acceptance confidence set at 0.8). OTUs representing less than $0.01 \%$ of the total number of observations (sequences) and OTUs that were only observed in a single sample were discarded. Downstream analyses were conducted using QIIME version 1.8.1 and $\mathrm{R}$ version 3.1.324.

\section{Taxonomy, alpha and beta diversity, microbial core}

Differences in the relative abundance of bacterial phyla and genera were compared between day 0 (surgery) and day 3 (sacrifice), between IL, PC and DC, and between groups with and without diclofenac (applicable to proximal colon samples) using either the Wilcoxon signed-rank test (for the paired samples between day 0 and day 3 ) or the Mann-Whitney-U-test (for unpaired comparisons). The following metrics of species richness and diversity within communities (alpha-diversity) were determined at a rarefaction depth of 34,150 sequences/sample: observed OTUs (observed richness), Chao1 index (estimated richness), and Shannon index (diversity). Alpha diversity metrics between paired samples from day 0 and day 3 were compared by the Wilcoxon signedrank test, whereas Mann Whitney $U$ tests were used to compare alpha diversity metrics of group IL/PC+ with DC+, and group PC- with group PC+. The total number of pairs that were included in the analyses were: $n=5$ for $P C-, n=14$ for $P C+$ and $n=10$ for $D C+$. All P-values were adjusted for multiple comparisons using the False Discovery Rate [Benjamini-Hochberg] ${ }^{25}$.

Beta-diversity, the diversity shared across samples, was determined by the Bray-Curtis dissimilarity $(\mathrm{BC})$ at a rarefaction depth of 34,150 sequences/sample. Clustering of samples was visualized using Principal Coordinate analysis (PCoA).

\section{Enterotyping}

Enterotype analyses were performed as described previously by Arummougham and colleagues $^{26}$. We used the R27 package "vegan: Community ecology", version 2.2-1 by Oksanen et al. from 2011 for calculating the Bray-Curtis distance on the genus-level relative abundance profiles. To cluster the samples, we used the Partitioning Around Medoids (PAM) clustering algorithm in the R27 package "Cluster analysis basics and extensions", version 2.0.1 ed. by Maechler et al. from 2012. The optimal number of clusters was chosen based on Calinski-Harabasz $(\mathrm{CH})$ index and validated by the silhouette index (57) using the R27 package 'clusterSim'. The optimal number of 2 clusters was identified based on the $\mathrm{CH}$ index, which was confirmed by the silhouette index although clustering was moderate (SI 0.47). 
Between-class analysis (BCA) was performed to plot the samples using the R27 package "Analysis of Ecological Data: Exploratory and Euclidean Methods in Environmental Sciences" version 1.7.2. by Dray et al. from 2015. The similarity percentage analysis (SIMPER)28 was used to identify taxa contributing to similarity within- and dissimilarity between groups.

\section{Results}

\section{Anastomotic leakage}

Animal welfare, mortality and anastomotic healing assessment results were published previously. In summary, leak rates were 10 out of 10 (100\%) in group IL+ and 22 out of $30(73 \%)$ in group $\mathrm{PC}+(22 / 30 ; 73 \% ; \mathrm{P}=0.166)$. Compared to group $\mathrm{PC}+$, rates were significantly lower in group $\mathrm{DC}+(1 / 10 ; 10 \% ; \mathrm{P}=0.001)$ and group $\mathrm{PC}-(0 / 15 ; 0 \%)$ $(P=0.001)$. The mean leak severity score was significantly higher in the $I L+$ group compared to the $\mathrm{PC}+$ group $(2.8 \pm 0.6$ vs. $1.7 \pm 0.5, \mathrm{P}=0.004)$ and significantly lower compared to the $\mathrm{DC}+$ group $(0.1 \pm 0.3, \mathrm{P}<0.001)$.

\section{Sequencing}

In total 96 faecal samples were collected during the experiment. Because of insufficient material 17 samples could not be analyzed. Two samples failed during sequencing and were excluded from subsequent analysis. In total 77 samples remained, from which a total of 4,869,671 $\mathrm{V} 4$ reads were retained for downstream analysis after trimming, quality filtering, removal of potential chimeric reads and de-multiplexing. The number of sequences per sample ranged from 34,198 to 87,981 (median 63,354). Sequences were then clustered into 2,182 OTUs. After discarding OTUs that were only observed in a single sample and OTUs with a relative abundance of $<0.01 \%, 1,005$ OTUs remained. The taxonomic composition of the samples on both phylum and genus level can be observed in Figures 9.1A and 9.1B, respectively. 


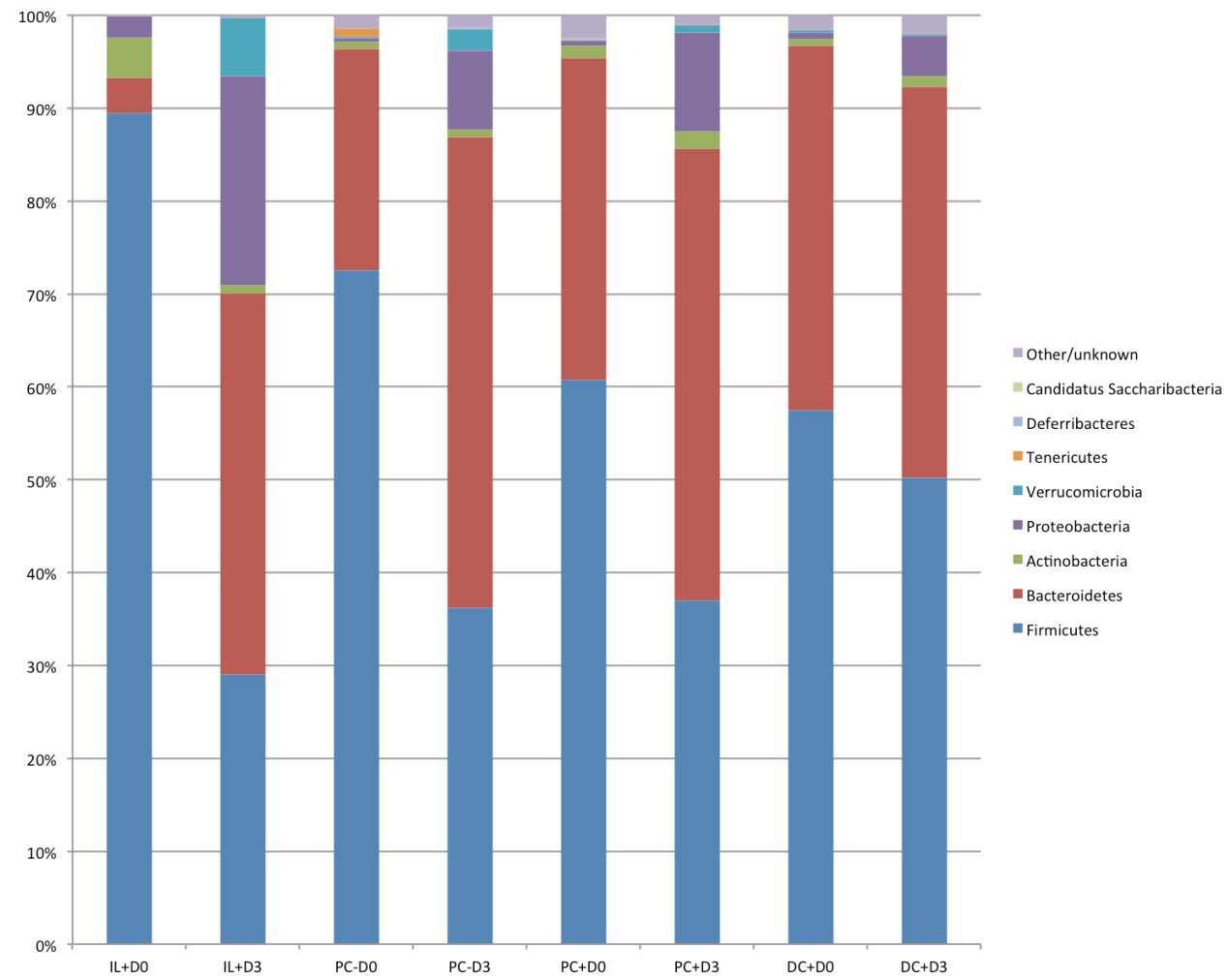

Figure 9.1A Phylum abundance in different anatomical regions (IL=ileum, PC=proximal colon, DC=distal colon), pre- (D0) and post-surgery (D3) and with or without diclofenac (+ or - respectively).

\section{Baseline microbiota composition and diversity in different segments of the intestinal tract}

\section{Taxonomy}

Phylogenetic classification of the microbiota in the different anatomical locations identified 21 different families belonging to 9 bacterial phyla. The most abundant phyla in the fecal samples obtained from the ileum were Firmicutes, followed by Bacteriodetes and Actinobacteria. The most abundant genera were Bacteroides, Lactobacillus, Escherichia-Shigella, Turicibacter and Bifidobacterium (relative abundance of 23.91, $8.92,7.17,2.72$ and $2.05 \%$ respectively). The genera that formed major constituents of the microbiota in the colon were Lactobacillus, Bacteroides, Alloprevotella, Blautia and Alistipes. More distally along the intestinal tract, the abundance of Firmicutes decreased, whereas Bacteriodetes showed an increase as compared to the ileum (see also supplementary material). 


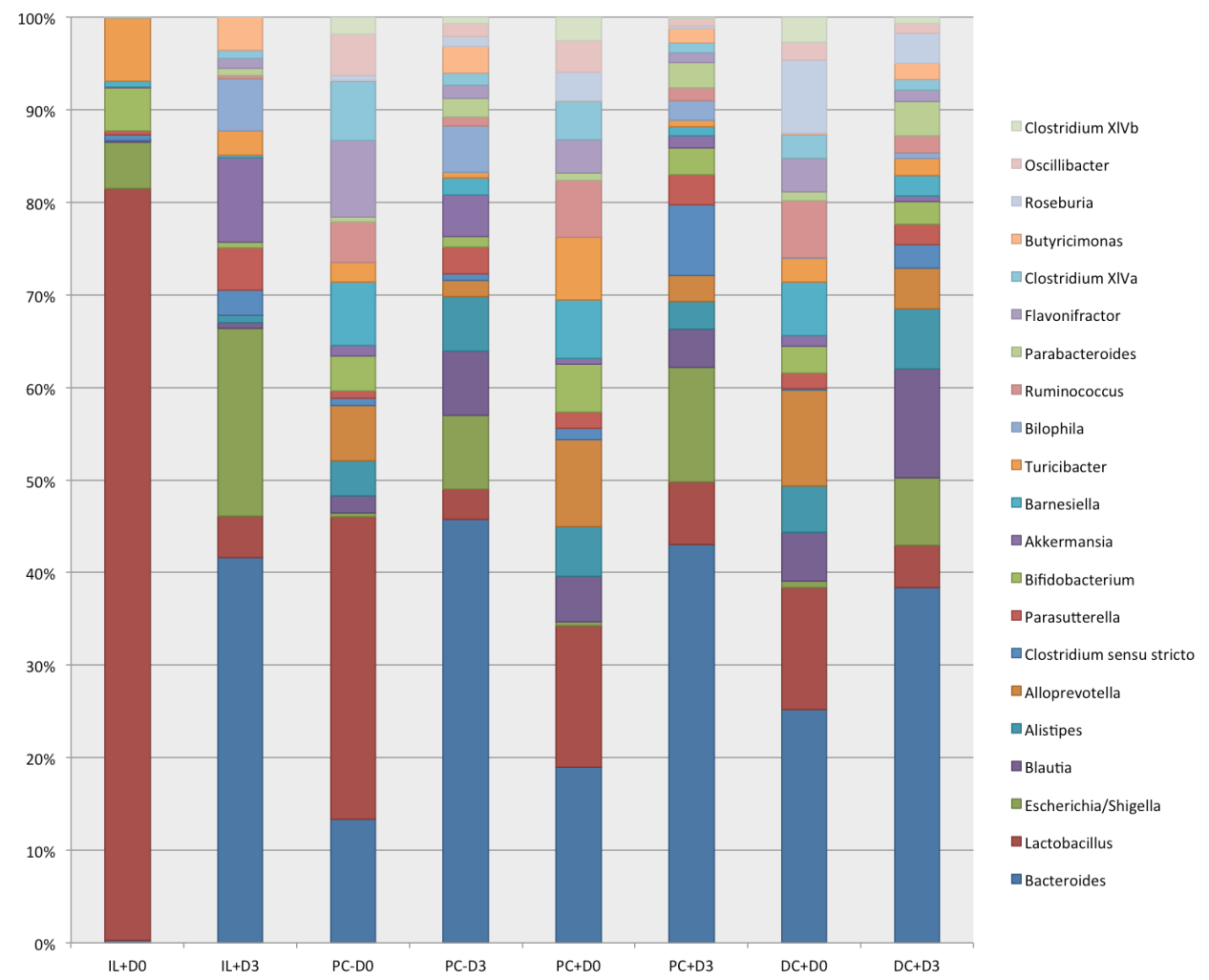

Figure 9.1B Genus abundance of 21 most abundant genera in different anatomical regions (IL=ileum, $\mathrm{PC}=$ proximal colon, $\mathrm{DC}=$ distal colon), pre- (D0) and post-surgery (D3) and with or without diclofenac (+ or - respectively).

\section{Microbial diversity and community structure}

Microbial richness and diversity of faeces samples collected before anastomosis construction was expressed as the number of observed species, Chao1 index and Shannon diversity index respectively. The analysis revealed baseline differences in diversity between the various segments of the intestine with a gradual increase in diversity from ileum towards the distal colon; see Figure 9.2 for a comparison of the different alpha diversity indexes. Preoperative faecal samples retrieved from the ileum demonstrated a significantly lower estimated microbial richness than samples retrieved from the proximal (PC- and PC+ combined) and distal colon ( $P=0.002$ and $P=0.001$ respectively, as calculated from Chao1 data). 

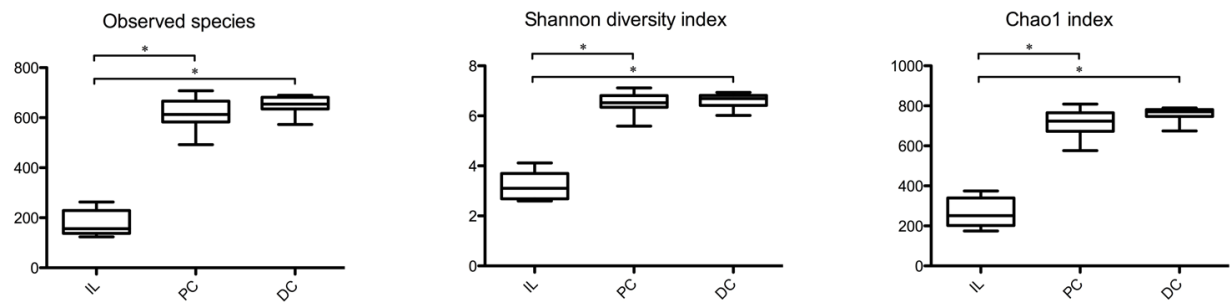

Figure 9.2 Comparison of alpha diversity indexes of pre-operative samples of the different anatomical locations: IL (ileum), PC (proximal colon), and DC (distal colon).

The microbial community structure, as expressed by the Bray-Curtis (BC) dissimilarity was also examined for each intestinal segment. Clustering of all samples based upon BC dissimilarities revealed a clear separation between ileal and colonic samples, represented by a separation along the first principal coordinate. Proximal and distal colonic samples did however not separate neither in this analysis nor when excluding ileal samples in a secondary analysis (results not shown).

\section{The influence of surgery on microbial diversity and community structure}

Surgery significantly decreased microbial richness and diversity in proximal (only PC+) and distal colon samples (Figure 9.3). A similar trend could not be observed in ileal samples, likely due to the limited number of paired pre- and post-surgery ileal samples.
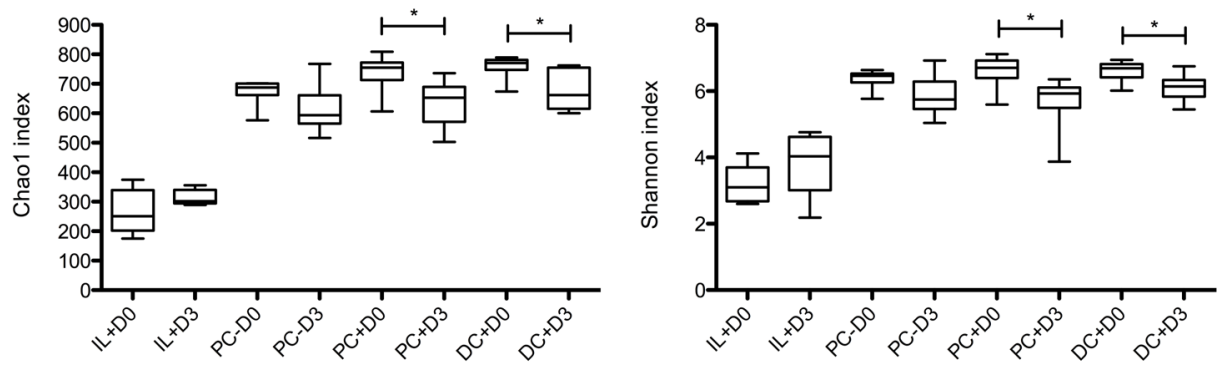

Figure 9.3 Microbial richness (Chao 1 and Shannon index) for all groups measured pre- and post-surgery. Asterisk indicates significance $<0.05$.

To further examine the effect of surgery on the microbial community structure in specific intestinal segments, a PCoA plot was created for each segment individually. A clear separation between pre- and post-operative proximal colon samples was observed 
along the first principal coordinate in PCoA plot based on the Bray-Curtis distance (Figure 9.4B). This separation was partially, but not completely, driven by a reduced microbial richness in post-operative samples (see supplementary data for a colored PCoA plot according to the Chao1 index). This surgery-effect was also observed for both ileum and distal colon samples (see Figure 9.4A and 9.4C respectively). In all intestinal segments, the same trend could be observed: all pre-operative samples clustered together, while the majority of the post-operative samples form a separate cluster with the exception of a few post-operative samples that remained clustered with the preoperative samples.

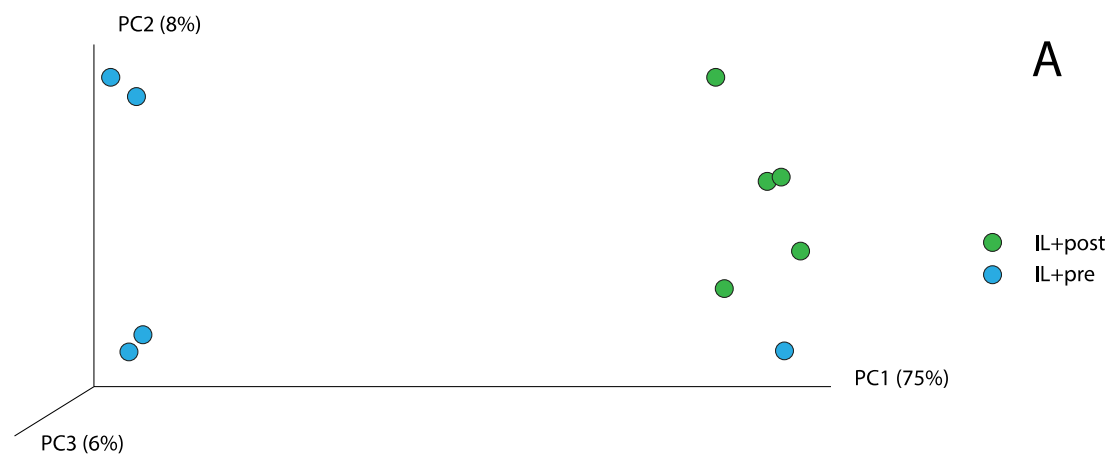

Figure 9.4A Bray-Curtis: the first principal coordinate shows the effect of surgery on ileum samples: $75 \%$ of the variation could be attributed to PC1.

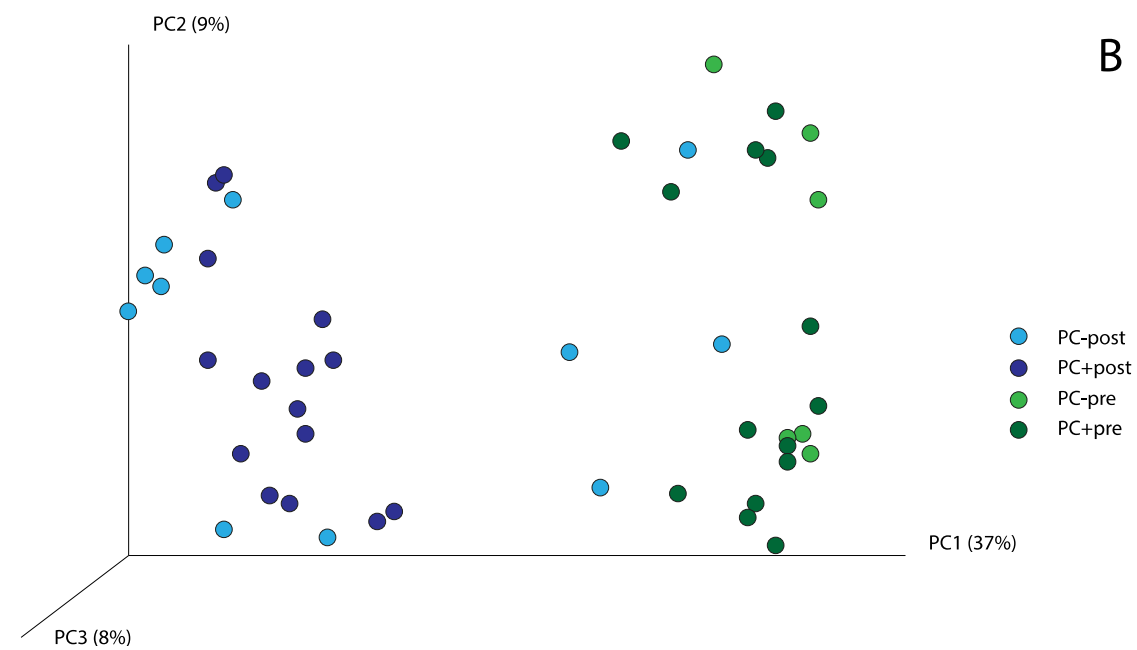

Figure 9.4B Bray-Curtis: the first principal coordinate shows the effect of surgery on PC+ and PC- proximal colon samples. No obvious effect of diclofenac can be observed in this separation. 


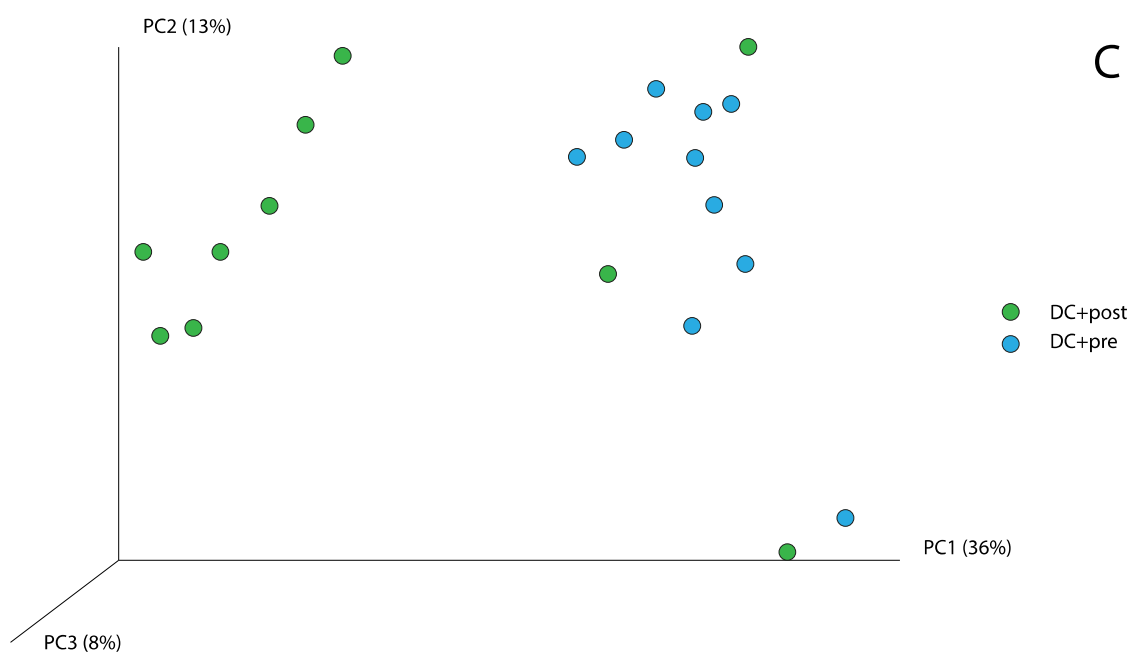

Figure 9.4C Bray-Curtis: the first principal coordinate shows the effect of surgery on distal colon samples.

\section{Enterotyping}

In order to further elucidate the origin of the clustering observed in the Bray-Curtis analyses of proximal colon samples enterotyping was performed based on Partitioning Around Medioids. The Silhouette score yielded the strongest evidence for clustering in two groups ( $\mathrm{SH}$ index=0.47), one group consisting of the pre-operative samples and one group consisting mainly of the post-operative samples. Bacterial taxa that contributed most to the observed clustering were the unclassified Lachnospiraceae, as well as Bacteroides and Esherichia-Shigella. Post-operatively, a marked decrease in the relative abundance of Lachnospiraceae could be observed and a sharp increase in the relative abundance of Bacteroides and Escherichia-Shigella.

Subsequently, paired analyses were performed to examine the differences in microbiome composition between pre- and post-operative proximal colon (PC+ and PC-) samples at phylum and genus levels (Figure 9.5A). These analyses revealed a significantly lower relative abundance of the Firmicutes phylum on D3 compared to D0 $(P<0,001)$, whilst the decrease in the abundance of Lactobacillus (the most important genus within this phylum) was not significant $(P=0.26)$. An overall increase in the phyla Bacteroidetes $(P=0.001)$ and the genera Bacteroides $(P<0.001)$ and Alistipes $(P<0.014)$ was observed, as well as an increase in the Proteobacteria phylum $(P<0.001)$, which confirmed the findings in the enterotyping analyses. The most important genera within the 
Proteobacteria phylum showed the expected postoperative increase (EscherichiaShigella $\mathrm{P}<0.001$, Bilophila $\mathrm{P}<0.001$ and Parasutterella $\mathrm{P}<0.001$ ). A postoperative decrease in overall relative abundance was found for the phylum of Candidatus Saccharibacteria $(\mathrm{P}=0.001)$.

As was the case for the PC samples, paired analysis of the distal colon samples revealed a significantly higher abundance of several genera within the Firmicutes phylum, including the Blautia $(P=0.005)$ and Clostridium sensu stricto $(P=0.022)$ genera preoperatively, as well as a bloom of Proteobacteria genera such as Escherichia-Shigella $(P=0.007)$ and Bilophila ( $p=0.009)$ post-operatively (Figure 9.5B).

\section{The effect of diclofenac administration on microbial diversity and composition}

\section{Alpha diversity}

As stated before, in the PC+ group a decrease in alpha diversity was observed in samples obtained at postoperative day 3 compared to the postoperative samples ( $P=0,001$ for both alpha diversity measures). In the proximal colon group that did not receive diclofenac, microbial richness was also lower post-operatively, but this difference did not reach statistical significance (Chao1 index PC-D0: Mdn. 687,59, PC-D3: Mdn. 593,82, $z=-1,483$ P=0,138, Shannon index PC-D0: Mdn. 6,46, PC-D3: Mdn. 5,75, z=-2,023, P>0,05 after FDR correction). Surprisingly, significant baseline differences in microbial richness were found between PC-DO and PC+DO samples collected before anastomosis construction (Chao1 index $P=0,035$ ), but not in microbial diversity, (Shannon index $\mathrm{P}=0,292$ ).

Despite these baseline differences, the diversity in the $\mathrm{PC}+\mathrm{D} 3$ group and $\mathrm{PC}-\mathrm{D} 3$ group was comparable (Chao 1 index PC+D3: Mdn. 652,97, PC-D3: Mdn. 593, 82, P=0,694, Shannon index PC+D3: Mdn. 5,93, PC-D3: Mdn. 5,75, P=0,823). The difference in diversity in the $P C+$ group between D0 and D3 was not significantly greater than that in the $P C$ - group $(P=0,123$ and $P=0,956$ for $C h a o 1$ and Shannon index respectively). See Figure 9.6 for the associations between the different time-points for the paired samples. 


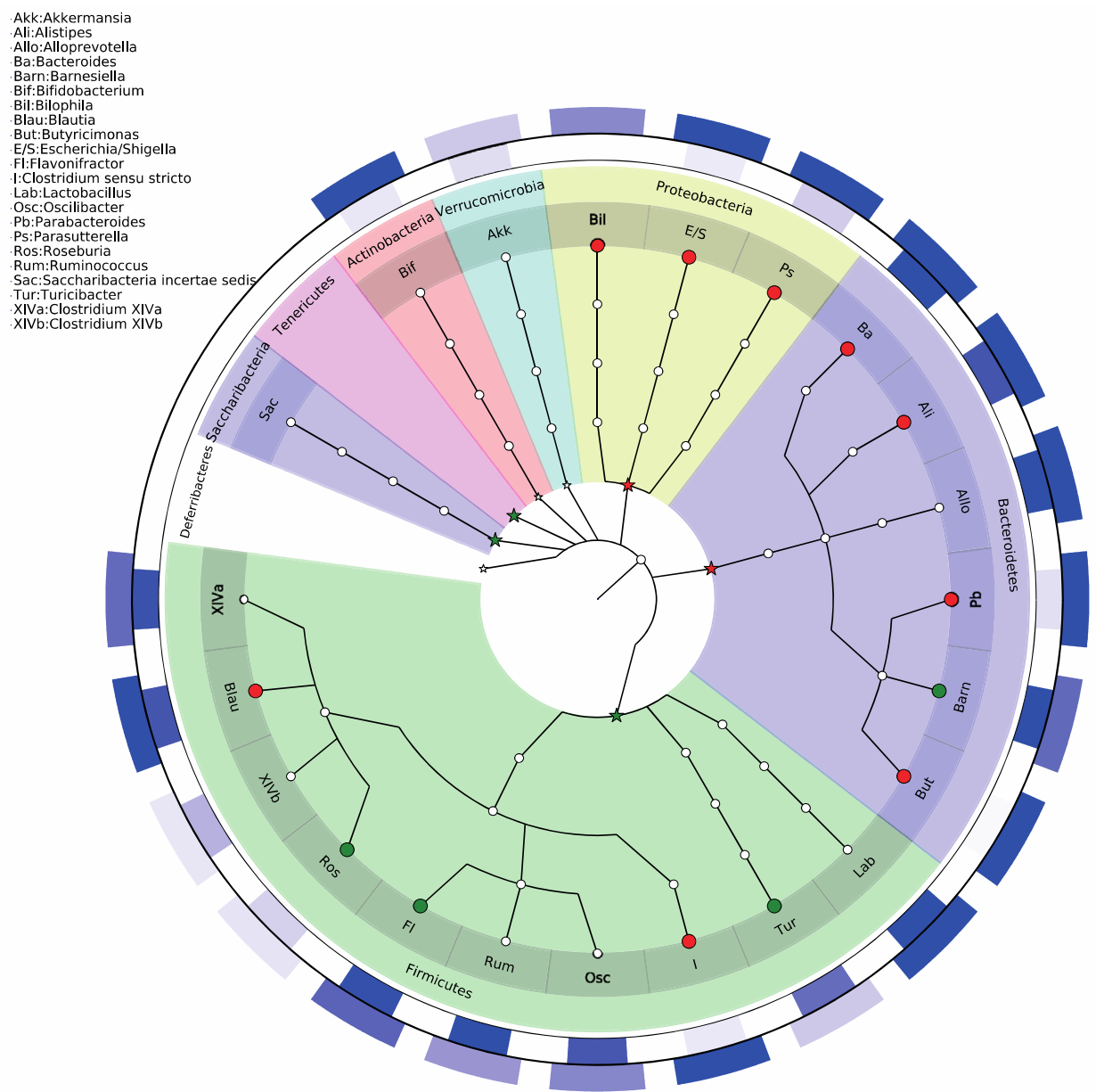

Figure 9.5A Cladogram representation of microbiota composition of proximal colon samples on different taxonomical levels. Green indicates significant higher relative abundance in pre-operative samples, higher relative abundance of post-operative samples is depicted in red. 


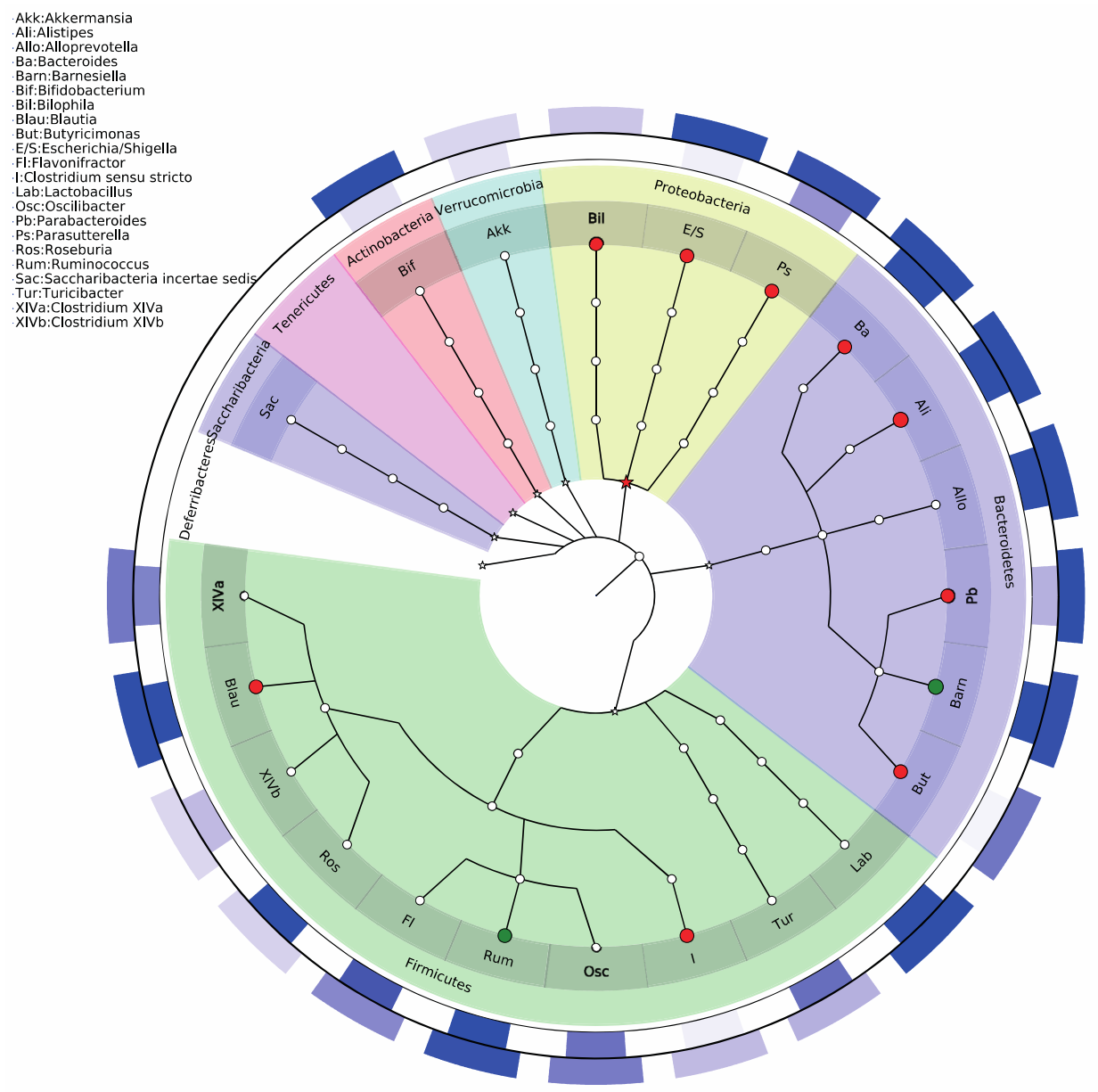

Figure 9.5B Cladogram representation of microbiota composition of distal colon samples on different taxonomical levels. Green indicates significant higher relative abundance in pre-operative samples, higher relative abundance of post-operative samples is depicted in red. 


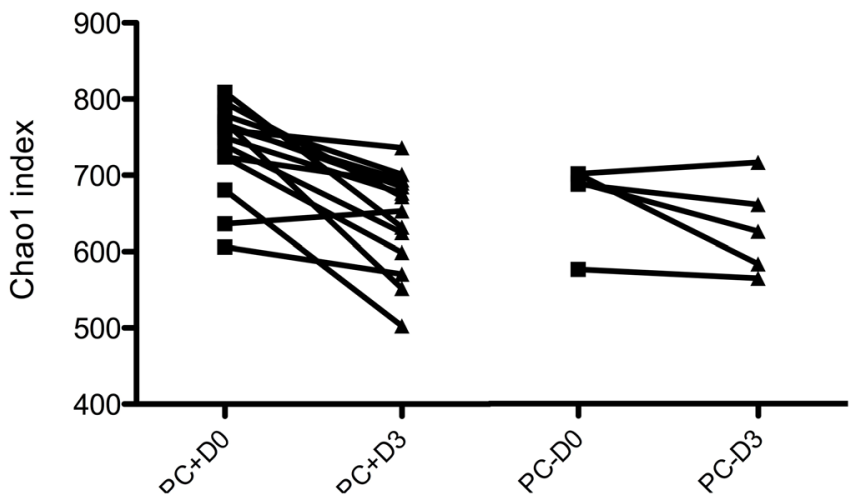

Figure 9.6 Difference in Chao1 index for paired samples on different time points between groups PC- and $\mathrm{PC}+$.

\section{Beta diversity}

To examine whether the microbial community structure within the PC+D3 and PC-D3 groups was more similar than the microbial community structure between the groups, the average within- and between-group Bray Curtis dissimilarity was examined. Samples within the PC+D3 group showed the strongest homogeneity, as indicated by significantly lower within-group Bray Curtis dissimilarity compared to the PC-D3 group ( $p=<0.001$ ) (Figure 90 7). When comparing OTUs between PC+D3 and PC-D3 group, only one out of $>1000$ OTU's was found to be significantly different: the OTU belonging to Anaerostipes from the family of Lachnospiraceae ( $p=0,046$ after FDR correction). Together with the similar post-operative decrease in alpha-diversity in the PC+D3 and PC-D3, these results provide little evidence for an effect of diclofenac administration on microbiota composition.

\section{Relation between microbial composition and diversity and the occurrence of $\mathrm{AL}$ in different intestinal segments}

Anastomotic leakage was observed in ileal and proximal colon (PC+) samples, but only sporadically in PC- or distal colon samples. For the analysis of the association between $\mathrm{AL}$ and microbial composition and diversity, only paired samples were taken into account: in the $\mathrm{PC}+$ group, $10 / 14$ rats $(71,4 \%)$ showed signs of $A L$, whereas only 1 of 10 rats in the distal colon (10\%) leaked. In order to investigate the relation between the microbial composition and the occurrence of leakage in the proximal colon and distal colon 
samples, we compared alpha diversity scores between leakage and non-leakage samples. Alpha diversity indices were not significantly different between postoperative leakage and non-leakage samples from the proximal colon (Chao1 index: Mdn. 642,40 vs. 682,91 respectively, $z=-0.990, P=0.37$, Shannon index: Mdn. 5,66 vs. 6,07 respectively, $z=-1,414, P=0.19$ ), or the distal colon (Chao1 index: Mdn. 606,00 vs. 665,53 respectively, $z=-1,219, P=0.40$, Shannon index: Mdn. 6.01 vs. 6.20, respectively, $z=-0,522, p=0.80)$.

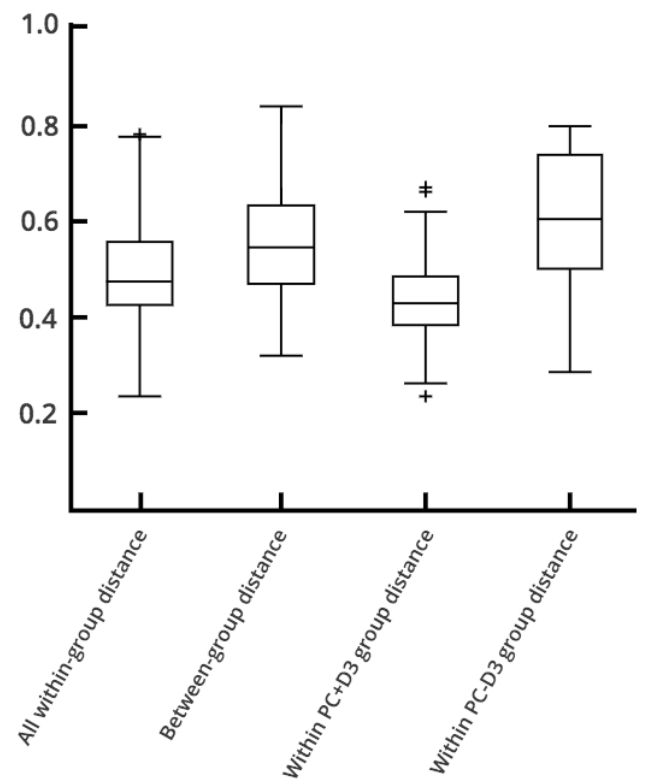

Figure 7.7 Within-group Bray-Curtis dissimilarity of proximal colon samples. Samples within the PC+D3 group showed the strongest homogeneity.

We further examined the relative abundance between the leakage and non-leakage samples in the PC+ group, which showed a significant lower relative abundance for the phylum Actinobacteria in the preoperative samples (Mdn. 0.0027 vs. $0.0219, z=-2.121$, $\mathrm{P}=0.035$ ) as well as a lower relative abundance of Bacteroidetes in the postoperative samples of the leakage group ( $M d n .0 .457$ vs. $0.567, z=-2.263, P=0.024$ ). The other most abundant genera and phyla showed no difference in relative abundance between leakage and non-leakage samples. 


\section{Discussion}

In the present study, the effect of anastomotic surgery and perioperative NSAIDs on the microbiome of different gut segments was explored. In the proximal and distal colon, a clear reduction of microbial diversity was observed three days after surgery. Changes were most apparent in the proximal colon and involved a diminution of the relative abundance of the Firmicutes (mainly attributed to a decrease in Lachnospiraceae) and an increase in the relative abundance of the Bacteroidetes phylum and Proteobacteria genera such as Escherichia-Shigella. The species richness did not change as evidently in the ileum as a result of the surgical intervention, but this can be explained by the relatively low richness at baseline. The PCOA on the other hand revealed a strong influence of surgery in the ileum: 75\% of the variance between D0 and D3 samples could be explained by the intervention. Contrary to our hypothesis and available literature, no significant difference was observed in taxonomic composition and diversity following diclofenac treatment.

A possible explanation is that the current study was not able to detect such influence, as surgery alone has proven to be a strong factor to alter the microbiota, and may have subsequently camouflaged influences exerted by the administration of diclofenac ${ }^{7}$. Other studies have shown that NSAID treatment lead to an obvious decrease in the number of gram-positive bacteria ${ }^{13,29}$. Another study found increased numbers of Enterobacteriaceae and Acidominococcaceae in the faeces of NSAID-users compared to controls $^{30}$.

The trauma of undergoing surgery alone may suffice in explaining the alteration of the normal microbial composition ${ }^{7}$. Lactobacilli and short chain fatty acids, both considered to have a cytoprotective effect, decrease by more than $90 \%$ within 6 hours after major trauma $^{31}$. Our results are also in concordance with a study by Shogan et al. in which a decrease in the relative abundance of the Firmicutes phylum and an increase in Proteobacteria genera such as Escherichia-Shigella was observed post-operatively ${ }^{5}$. Shogan et al., however, found a more dramatic increase in the relative abundance of Enterococcus. Because of the short time frame in which this alteration takes place, it is considered to be a result from chemosignalling rather than a depletion of nutrients in the gut ${ }^{32}$. Another possible explanation is the exposure of the gut lumen to atmospheric air, which will affect the obligate anaerobic species ${ }^{33,34}$.

Several features of the luminal content as well as the structure of the intestine have been suggested to play a role in the observed segmental differences ${ }^{17,18}$. The small intestinal content is known to have a lower $\mathrm{pH}$, higher oxygen and bile acid levels as compared to the colon, which facilitates colonization by facultative anaerobes, mainly Lactobacillaceae and Enterobacteriaceae (belonging to the Firmicutes and 
Proteobacteria phyla respectively). The colon on the other hand, characterized by low oxygen levels, slow transit and high nutrient levels, is mainly inhabited by Bacteriodetes or Firmicutes phyla. The microbiome changes observed in this study were greater in the proximal colon compared to the distal colon. The anastomotic leak rate was also higher in the proximal colon.

It is possible that the microbial shift in the proximal colon increased its susceptibility to damage caused by diclofenac. Other studies have shown that certain antibiotics and probiotics reduce the severity of NSAID-induced enteropathy, especially when they target gram-negative bacteria ${ }^{35,36}$. Another important clue for the interaction between NSAIDs and bacteria is the finding that NSAID enteropathy does not occur in germ free mice, but, when Eubacterium limosum or E. coli is introduced, intestinal ulceration is observed $^{10,37}$.

However, there may be other explanations than an altered microbiota composition for the increased leakage rates in the ileum and proximal colon in this study. Inhibition of cyclo-oxygenase (COX) consequently leads to inhibition of its products: the prostaglandins. By inhibiting the prostaglandins E2 (PGE2) and I2 (PGI2), two important inflammatory mediators in the gut, several hallmarks of inflammation are reduced as well $^{38}$. As they also play an important role as mediators of mucosal defence and repair, NSAID administration leaves the gut lining more susceptible to cytotoxic components of the luminal content ${ }^{39}$.

Another property of this group of drugs that may explain the observed alterations is their metabolism. Many NSAIDs (including diclofenac) are excreted through bile after being absorbed in the distal intestine and being glucuronidated in the liver. After their excretion together with the bile (free or glucuronidated), they exert secondary effects on the intestinal wall, contributing to epithelial damage ${ }^{40}$.

The decrease in the relative abundance of Lachnospiraceae observed in the colonic segments may have detrimental consequences for epithelial permeability as many of the intestinal butyrate producers belong to the Lachnospiraceae family ${ }^{41}$. Aside from facilitating tight junction assembly, butyrate is associated with many other beneficial properties in the colon. Butyrate acts as an energy source for intestinal epithelial cells, reduces oxidative stress in the mucosa and by extension inflammation, and is an anticarcinogenic $^{42}$. Interestingly, in inflammatory bowel disease the most consistent change that is observed is also a marked decrease in the representation of the Firmicutes phylum (including Lachnospiraceae) ${ }^{43}$. 
No clear association between microbial composition and the occurrence of anastomotic leakage was found in this study. This could be explained by the relatively low numbers of leakage, as well as the strong influence of the surgical intervention on the microbiota. A recently conducted clinical study did find a positive correlation between the occurrence of CAL and low microbial diversity, as well as with a high abundance of Bacteroidaceae and Lachnospiraceae families ${ }^{44}$. It has been further suggested that aside from microbial composition and diversity, microbial virulence also plays an important role in leakage pathogenesis. Bacteria have been shown to demonstrate an upregulation of virulence factors such as collagenase activity, swarming motility and epithelial adhesion in response to changes in their direct environment such as phosphate depletion ${ }^{45}$, release of inflammatory mediators ${ }^{46}$, and the release of endogenous opioids ${ }^{47}$. Even symbiotic microbes can express virulence as a reaction to cues coming from their host. This increase in bacterial virulence can promote the emergence of a pathobiome capable of penetrating the intestinal barrier and causing anastomotic leak ${ }^{32,48}$. In order to investigate this hypothesis, analyses cannot remain limited to taxonomic composition and diversity quantification; analysis of the functional context of microbial species is vital in order to determine the clinical relevance of the presence of specific bacterial species.

The strength of this study is the simplicity of the model used; results are not tainted by the administration of antibiotics, bowel preparation or radiotherapy - interventions that are commonly used in other animal experiments and, most importantly, in clinical practice. This allowed us to isolate and identify changes on the microbiota composition that were induced by surgery or NSAIDs alone. We included the proximal colon anastomosis in our experiments, a type of anastomosis that is often neglected in experimental CAL research, despite the fact that right-sided (ileocolic) anastomosis are common and show significant leak rates in recent series ${ }^{49}$. The most important limitation of this study is the low leak rate of the distal colon anastomoses, which can largely be attributed to the type of model used. Several additional interventions can be employed in order to increase the leakage rate of distal anastomoses (e.g. ischemia, radiotherapy, morphine), but this would increase the complexity of this specific model and would hamper interpretation of single intervention effects.

In summary, surgical stress, and not NSAID treatment, prompts a shift in microbial composition and decrease in diversity in a rat model of NSAID induced anastomotic leak. The increased risk for AL that is induced by the administration of NSAIDs is therefore likely to be attributable to other properties of this drug class. However, as microbial changes have been previously described to occur with the use of NSAIDs, more research is needed to clarify if these changes make the gut more susceptible to diclofenacinduced leakage and anastomotic leak in general. 


\section{References}

1. Kim CW, Baek SJ, Hur H, et al. Anastomotic leakage after low anterior resection for rectal cancer is different between minimally invasive surgery and open surgery. Ann Surg 2016;263(1):130-7.

2. Frasson M, Flor-Lorente B, Rodriguez JL, et al. Risk Factors for Anastomotic Leak After Colon Resection for Cancer: Multivariate Analysis and Nomogram From a Multicentric, Prospective, National Study With 3193 Patients. Ann Surg 2015;262(2):321-30.

3. Roos D, Dijksman LM, Tijssen JG, et al. Systematic review of perioperative selective decontamination of the digestive tract in elective gastrointestinal surgery. Br J Surg 2013;100(12):1579-88.

4. Schardey HM, Joosten $U$, Finke $U$, et al. The prevention of anastomotic leakage after total gastrectomy with local decontamination. A prospective, randomized, double-blind, placebo-controlled multicenter trial. Ann Surg 1997;225(2):172-80.

5. Shogan BD, Smith DP, Christley $\mathrm{S}$, et al. Intestinal anastomotic injury alters spatially defined microbiome composition and function. Microbiome 2014;2:35.

6. Shogan BD, Belogortseva N, Luong PM, et al. Collagen degradation and MMP9 activation by Enterococcus faecalis contribute to intestinal anastomotic leak. Sci Transl Med 2015;7(286):286ra68.

7. Shakhsheer BA, Versten LA, Luo JN, et al. Morphine promotes colonization of anastomotic tissues with collagenase - producing enterococcus faecalis and causes leak. J Gastrointest Surg 2016;20(10):1744-51.

8. Peng F, Liu S, Hu Y, et al. Influence of perioperative nonsteroidal anti-inflammatory drugs on complications after gastrointestinal surgery: A meta-analysis. Acta Aanaesthesiol Taiwan 2016;54(4): 121-8.

9. Bhangu A, Singh $P$, Fitzgerald JE, et al. Postoperative nonsteroidal anti-inflammatory drugs and risk of anastomotic leak: meta-analysis of clinical and experimental studies. World J Surg 2014;38(9):2247-57.

10. Uejima M, Kinouchi T, Kataoka K, et al. Role of intestinal bacteria in ileal ulcer formation in rats treated with a nonsteroidal antiinflammatory drug. Microbiol Immunol 1996;40(8):553-60.

11. Reuter BK, Davies NM, Wallace JL. Nonsteroidal anti-inflammatory drug enteropathy in rats: role of permeability, bacteria, and enterohepatic circulation. Gastroenterology 1997;112(1):109-17.

12. Wallace JL, Syer S, Denou E, et al. Proton Pump Inhibitors Exacerbate NSAID-Induced Small Intestinal Injury by Inducing Dysbiosis. Gastroenterology 2011;141(4):1314-22.e5.

13. Hagiwara $\mathrm{M}$, Kataoka $\mathrm{K}$, Arimochi $\mathrm{H}$, et al. Role of unbalanced growth of gram-negative bacteria in ileal ulcer formation in rats treated with a nonsteroidal anti-inflammatory drug. J Med Invest 2004;51(1-2):43-51.

14. Dalby $A B$, Frank DN, St. Amand AL, et al. Culture-independent analysis of indomethacin-induced alterations in the rat gastrointestinal microbiota. Appl Environ Microbiol 2006;72(10):6707-15.

15. Shogan BD, Belogortseva N, Luong PM, et al. Collagen degradation and MMP9 activation by Enterococcus faecalis contribute to intestinal anastomotic leak. Sci Transl Med 2015;7(286):286ra68.

16. Yauw ST, Lomme RM, van der Vijver RJ, et al. Diclofenac causes anastomotic leakage in the proximal colon but not in the distal colon of the rat. American journal of surgery 2015;210(2):382-8.

17. Donaldson GP, Lee SM, Mazmanian SK. Gut biogeography of the bacterial microbiota. Nat Rev Microbiol 2016;14(1):20-32.

18. Thomas LA, Veysey MJ, French G, et al. Bile acid metabolism by fresh human colonic contents: a comparison of caecal versus faecal samples. Gut 2001;49(6):835-42.

19. Yauw ST, Lomme RM, van der Vijver RJ, et al. Diclofenac causes anastomotic leakage in the proximal colon but not in the distal colon of the rat. Am J Surg 2015;210(2):382-8.

20. Mack I, Cuntz U, Gramer $\mathrm{C}$, et al. Weight gain in anorexia nervosa does not ameliorate the faecal microbiota, branched chain fatty acid profiles, and gastrointestinal complaints. Sci Rep 2016;6. ,

21. Caporaso JG, Lauber CL, Walters WA, et al. Ultra-high-throughput microbial community analysis on the Illumina HiSeq and MiSeq platforms. ISME J 2012;6(8):1621-4.

22. Hildebrand F, Tadeo R, Voigt AY, et al. LotuS: an efficient and user-friendly OTU processing pipeline. Microbiome 2014;2(1):30.

23. Edgar RC. UPARSE: highly accurate OTU sequences from microbial amplicon reads. Nat Methods 2013;10(10):996-8.

24. Caporaso JG, Kuczynski J, Stombaugh J, et al. QIIME allows analysis of high-throughput community sequencing data. Nat Methods 2010;7(5):335-6. , 
25. Benjamini Y, Hochberg Y. Controlling the False Discovery Rate - a Practical and Powerful Approach to Multiple Testing. J Roy Stat Soc B Met 1995;57(1):289-300.

26. Arumugam $M$, Raes J, Pelletier $E$, et al. Enterotypes of the human gut microbiome. Nature 2011;473(7346):174-80.

27. Team RC. R: A language and environment for statistical computing. In: R Foundation for Statistical Computing. Vienna, Austria. 2013. http://www.R-project.org/.

28. Clarke KR. Non-parametric multivariate analyses of changes in community structure. Aust J Ecol 1993; 18(1):117-43.

29. Dalby $A B$, Frank $D N$, St Amand $A L$, et al. Culture-independent analysis of indomethacin-induced alterations in the rat gastrointestinal microbiota. Appl Environ Microbiol 2006;72(10):6707-15.

30. Rogers MAM, Aronoff DM. The influence of non-steroidal anti-inflammatory drugs on the gut microbiome. Clin Microbiol infect 2016;22(2):178 e1- e9.

31. Hayakawa M, Asahara T, Henzan N, et al. Dramatic changes of the gut flora immediately after severe and sudden insults. Dig Dis Sci 2011;56(8):2361-5.

32. Krezalek MA, DeFazio J, Zaborina O, et al. The shift of an intestinal "Microbiome" to a "Pathobiome" governs the course and outcome of sepsis following surgical injury. Shock 2016;45(5):475-82.

33. Bingold TM, Ziesche E, Scheller B, et al. Interleukin-22 detected in patients with abdominal sepsis. Shock 2010;34(4):337-40.

34. Hartman AL, Lough DM, Barupal DK, et al. Human gut microbiome adopts an alternative state following small bowel transplantation. Proc Natl Acad Sci U S A 2009;106(40):17187-92.

35. Kinouchi T, Kataoka K, Bing SR, et al. Culture supernatants of Lactobacillus acidophilus and Bifidobacterium adolescentis repress ileal ulcer formation in rats treated with a nonsteroidal antiinflammatory drug by suppressing unbalanced growth of aerobic bacteria and lipid peroxidation. Microbiol Immunol 1998;42(5):347-55.

36. Syer SD, Blackler RW, Martin R, et al. NSAID enteropathy and bacteria: a complicated relationship. J Gastroenterol 2015;50(4):387-93.

37. Robert A, Asano T. Resistance of germfree rats to indomethacin-induced intestinal lesions. Prostaglandins 1977;14(2):333-41.

38. Wallace JL. Mechanisms, prevention and clinical implications of nonsteroidal anti-inflammatory drugenteropathy. World J Gastroenterol 2013;19(12):1861-76.

39. Wallace JL. Prostaglandins, NSAIDs, and gastric mucosal protection: why doesn't the stomach digest itself? Physiol Rev 2008;88(4):1547-65.

40. Somasundaram S, Rafi S, Hayllar J, et al. Mitochondrial damage: a possible mechanism of the "topical" phase of NSAID induced injury to the rat intestine. Gut 1997;41(3):344-53.

41. Peng L, Li ZR, Green RS, et al. Butyrate enhances the intestinal barrier by facilitating tight junction assembly via activation of AMP-activated protein kinase in Caco-2 cell monolayers. J Nutr 2009;139(9):1619-25.

42. Hamer HM, Jonkers DM, Bast A, et al. Butyrate modulates oxidative stress in the colonic mucosa of healthy humans. Clin Nutr 2009;28(1):88-93.

43. Peterson DA, Frank DN, Pace NR, et al. Metagenomic approaches for defining the pathogenesis of inflammatory bowel diseases. Cell Host Microbe 2008;3(6):417-27.

44. van Praagh JB, de Goffau MC, Bakker IS, et al. Mucus microbiome of anastomotic tissue during surgery has predictive value for colorectal anastomotic leakage. Ann Surg 2019;269(5):911-916.

45. Long J, Zaborina O, Holbrook C, et al. Depletion of intestinal phosphate after operative injury activates the virulence of $P$ aeruginosa causing lethal gut-derived sepsis. Surgery 2008;144(2):189-97.

46. Wu L, Estrada O, Zaborina O, et al. Recognition of host immune activation by Pseudomonas aeruginosa. Science (New York, NY) 2005;309(5735):774-7.

47. Zaborina O, Lepine F, Xiao G, et al. Dynorphin activates quorum sensing quinolone signaling in Pseudomonas aeruginosa. PLoS Pathog 2007;3(3):e35.

48. Olivas AD, Shogan BD, Valuckaite $V$, et al. Intestinal tissues induce an SNP mutation in Pseudomonas aeruginosa that enhances its virulence: possible role in anastomotic leak. PloS One 2012;7(8):e44326.

49. Iversen $\mathrm{H}$, Ahlberg $\mathrm{M}$, Lindqvist $\mathrm{M}$, et al. Changes in clinical practice reduce the rate of anastomotic leakage after colorectal resections. World J Surg 2018;42(7):2234-2241. 
Supplementary data

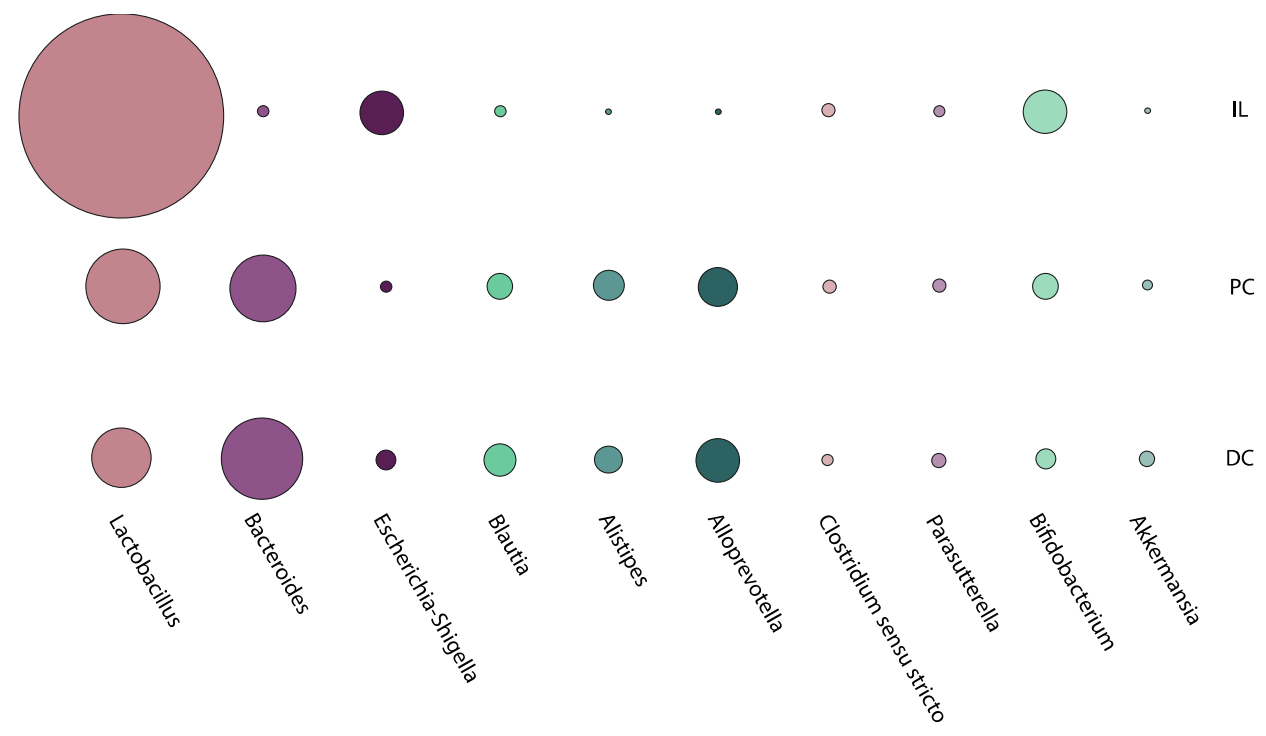

Bubblechart depicting the relative abundance of the ten most common genera in the ileum (IL), proximal colon (PC) and distal colon (DC). 



\section{Chapter 10}

General discussion 



\section{General discussion}

Colorectal cancer is the most common oncological disease in the Netherlands, with over 15.000 newly diagnosed cases every year. This number is thought to further increase due to the recently initiated national colorectal cancer-screening program and the ageing population. The large majority of patients that undergo treatment in a curative setting will eventually undergo colorectal surgery. Although several techniques can be used, depending on tumour location, the majority of these include resection of the diseased bowel part, which is usually followed by the construction of an anastomosis in order to restore bowel continuity. One of the most feared complications after this type of surgery remains colorectal anastomotic leakage $(C A L)$, in which a failure of the anastomosis leads to spill of faecal content into the normally sterile abdominal cavity. The presence of faecal material and bacteria can induce the formation of abscesses, peritonitis, and in severe cases sepsis, and may eventually lead to death. Despite the fact that important improvements have been made in the perioperative care, such as the implementation of fast-track protocols, advances in anaesthesia and minimally invasive techniques, the numbers of leakage have remained stable over the past decades around $7-10 \%{ }^{1}$. The occurrence of CAL has been associated with increased rates of morbidity and mortality, negatively affects health-related quality of life due the increased risk of reoperation and the construction of a permanent ileo- or colostomy, increases health care costs by a threefold and, finally, is associated with an increased risk of cancer recurrence and cancer-related death ${ }^{2-5}$.

In this thesis, we have focused on several important aspects of colorectal anastomotic leakage in different phases of care for the colorectal patient.

\section{PART I: increasing international consensus on the definition of colorectal anastomotic leakage}

In the first part of the thesis, we have aimed at increasing insight in the use of different definitions for CAL. The definition of what exactly should be considered a leakage after colorectal anastomotic surgery has remained a topic of discussion for many years. Our literature study in Chapter 3 showed that no common definition exists, despite the fact that the number of papers published on this topic has increased tremendously over the years, and despite the fact that several new definitions have been proposed ${ }^{6}$. The heterogeneity in study outcome hampers the execution of statistically strong metaanalyses, that are needed to provide level $A$ evidence for recommendations and 
guidelines. Furthermore, we believe it is important to strive for uniformity on the reporting of clinical data as well, as this would increase understanding of certain findings and further aid the comparison of studies. Uniformity in data reporting has gained increased attention over the years and has led to the formulation of the CONSORT statement for RCTs. We believe that adherence to such guidelines greatly improves data reporting and we are in favour of the use of similar formats for studies conducted in the field of CAL.

The survey study (Chapter 2) increased our insight in the differences of what surgeons consider an anastomotic leak in different countries (in this case, the Netherlands and China), and partly explained an important variation between reported leakage rates in Western and Eastern clinical studies ${ }^{7-10}$. Such differences can of course partially be explained by variables such as operation technique, tumour location and patient characteristics. We investigated whether these reported differences could also be explained by differences in definitions used in separate countries.

Both studies stress the need for a new and generally accepted definition, and indicate the importance of guidelines with regards to what topics and data should be addressed in new studies considering colorectal anastomotic leakage. In collaboration with the Dutch Taskforce for Anastomotic Leakage, we drafted a set of 11 points that we advise to report in newly published papers.

\section{Future perspectives and recommendations}

In our literature study, we show that authors tend to formulate their own definitions rather than using an existing definition. This can be caused by the existence of broad or rather vague definitions such as 'a defect in the bowel wall at the anastomotic site, leading to communication of intra- and extraluminal compartments ${ }^{\prime 1}$, which can be difficult to use in clinical practice. Furthermore, we feel that it is important to increase support by the scientific community in order to improve implementation of new definitions. In the first part of this thesis, we laid the foundation of the discussion for the proper definition of colorectal anastomotic leakage, which is currently being formulated by the use of a worldwide Delphi analysis. This analysis will be done with the help of renowned international researchers and colorectal surgeons in order to increase the final implementation of a newly formed definition. The co-authors and myself strongly believe that the use of a graded system with treatment recommendations for the different severity grades will enhance uniformity of patient care and may lead to decreased delay in treatment. 


\section{PART II: Developing a predictive algorithm for anastomotic leakage}

Many studies have been conducted focusing on risk factors for leakage, which can be subdivided into patient and surgery related risk factors. Patient related risk factors include genetic predisposition, drug use such as NSAIDs or steroids, smoking, male gender and old age and preoperative radiotherapy ${ }^{12-16}$. Surgery-related risk factors include the height of the anastomosis (the closer to the anal verge, the higher the risk of $\mathrm{CAL}$ ), duration and amount of blood loss during surgery, the oxygenation of the tissue and the microbiota composition of the gut ${ }^{1,17}$. Despite the knowledge of these risk factors, it is impossible to make an adequate risk assessment for the risk of CAL for every individual patient. The results of the REVEAL study (Chapter 4), in which we aim to develop a predictive algorithm for the risk of anastomotic leakage, will aid the physicians involved in colorectal care and their patients to make tailored decisions to the construction of a deviating ostomy and an anastomosis prior to undergoing surgery. The results of the study will further lead to earlier detection of anastomotic leakage. In the early postoperative phase, physicians rely on nonspecific markers such as fever, abdominal pain and C-Reactive Protein (CRP) levels in blood to distinguish a patient with a normal postoperative course from a patient that is suffering from a small or fulminant anastomotic leak ${ }^{18,19}$. It has been shown that early recognition of the problem leads to early intervention, and this in turn helps to keep the clinical consequences to a minimum ${ }^{20}$. As many of the patients with CAL display nonspecific signs and symptoms, CT scans are commonly used to exclude the presence of an anastomotic leak in case an abnormal postoperative course is suspected. Unfortunately, the false-negative rates of CT scans are relatively high, which often leads to a significant delay in diagnosis and initiation of treatment ${ }^{21,22}$.

As part of the on-going REVEAL study, we studied the composition of volatile organic compounds (VOCs) in exhaled air and examined whether this composition shifts in the event of a leak. Volatile organic compounds in breath are a reflection of metabolic processes in our body both from exogenous (bacteria, viruses) and endogenous sources, of which the breakdown products are released into the blood stream and, via the alveoli, into the exhaled air $^{23}$. We investigated whether specific metabolic profiles can be used as an early predictor of colorectal anastomotic leakage. We have sampled a large number of patients prior to surgery and on every postoperative day, and are currently analysing the samples by means of mass spectrometry.

Apart from the preoperative phase, a lot of information can be gained from the period of surgery itself. As mentioned before, attention should be taken regarding several perioperative factors such as the mean blood pressure, body temperature and the 
amount of blood loss, as they have been shown to influence the postoperative course after major surgery. With regards to colorectal surgery, another parameter is of interest: the microperfusion of the intestine, as this has been suggested to be predictive for colorectal anastomotic leakage ${ }^{24,25}$. In Chapter 5, we have focused on the use of near infrared imaging (NIRF) to assess the quality of perfusion of the intestine, and the influence of fluorescence intensity on the incidence of colorectal anastomotic leakage in a small group of patients who were also included in the REVEAL study (Chapter 4). In this pilot study, we found that fluorescence intensity was significantly lower in patients who eventually developed CAL. We however did not find a relationship between signal intensity or anastomotic leakage and several markers for intestinal healing or cell damage, which can partly be attributed to the lack of specificity of these markers and the relatively small sample size ${ }^{26}$. We believe that larger patient numbers are needed to further investigate these relationships and to formulate cut-off values for the fluorescent signal.

\section{Future perspectives and recommendations}

Many generations of both clinical and experimental researchers have focused on the problem of colorectal anastomotic leakage, and despite many important revelations that have been done over the past decades, CAL remains an important postoperative problem in a relatively large portion of patients. Clearly, with the finishing of this thesis, we have been unable to get rid of this feared complication. However, important steps have been taken in the right direction. For example, the REVEAL study is nearly coming to an end, which means that very soon we will be able to implement a reliable risk assessment tool in the preoperative work up of every individual patient diagnosed with colorectal cancer. With the use of computer learning algorithms, we will be able to find the most reliable combination of markers in for example blood, stool and exhaled air. Eventually, we will be able to allocate every individual patient to a risk classification before the surgery has even taken place. This would be very useful in the discussion between health care professional and patient with regards to construction of an an anastomosis and/or a deviating ostomy. Furthermore, as the study also aims to decrease the treatment delay that is now often seen because of the lack of reliable postoperative markers, we believe that fewer casualties will be caused by the complication due to early recognition of the problem.

We believe that colorectal anastomotic leakage is a multifactorial disease, with numerous known and possibly unknown risk factors involved. This has made preoperative risk assessment and even postoperative diagnosis unspeakably difficult. We however feel that with the use of large patient populations and datasets (for example 
from existing databases and innovative computational techniques), it is possible to overcome these difficulties. We therefore strongly support the collaborative trend we see in all fields of medicine and also in research focused on colorectal anastomotic leakage, of which the Dutch Taskforce is a very good example.

As mentioned above, in Chapter 5 we focused on the use of NIRF imaging to assess microperfusion of the intestine. In this pilot study, we tried to establish an objective cutoff value for the fluorescent signal to predict CAL, but failed to do so due to the small sample size. As we believe that NIRF imaging can be used as a safe and effective method to assess the perfusion of the intestine at the site of the future anastomosis ${ }^{27}$, a larger study with a larger sample size is recommended in order to determine the ideal cut-off for signal intensity.

\section{PART III: Considerations regarding perioperative care of the colorectal surgical patient}

In the third part of this thesis we have focused on important aspects and questions regarding the perioperative care of the colorectal patient. During the past decade, enhanced recovery after surgery protocols have been implemented in order to shorten time of hospitalization, decrease the number of adverse events after surgery and fasten the general recovery of our patients after invasive surgery. For every individual patient, important decisions have to be made before, during and after surgery. In this thesis, several aspects of the perioperative care have been studied.

In many cases, it is decided during surgery whether a diverting ostomy is made to protect the anastomosis from the passing faecal stream. The practice of whether or not to construct a temporary (ileo)stomy also differs heavily between surgeons and institutions, and like many subjects in this surgical field, no clear guidelines exist on this topic. In case a temporary ostomy is indeed constructed, it is also unclear which type of stoma (ileo or colon) and which interval between the primary surgery and the stoma reversal is preferable. Another question is which diagnostic tool is most accurate in the assessment of the integrity of the anastomosis before temporary stoma reversal. The latter was investigated in Chapter 6, where we used a large national cohort of patients operated because of rectal carcinoma in 2011, and in which we investigated the accuracy of colonoscopy and contrast enema to assess the patency of the rectal anastomosis. Very little literature exists on the routine use of colonoscopy in order to evaluate the quality of the anastomosis, but it is generally considered safe in use and is

associated with low costs. The contrast enema is also known to be safe in use ${ }^{28,29}$, but is associated with the risk of false positive test, where contrast is seen in the 'dog ears' of 
the staple line and confused for extraluminal leakage. In up to $41 \%$, contrast enema detects radiological leaks that may not require intervention ${ }^{18}$. In those cases, the temporary ostomy could have been safely reversed. Despite the lack of a statistical significant difference in the odds of the diagnosis of anastomotic leakage between the two modalities, several advantages for the colonoscopy can be described, as it can also detect intraluminal cancer recurrence (although rare), advanced adenomas and anastomotic stricture, which occurs in up to $30 \%$ of cases, and can then be immediately used to resolve the stenosis by means of balloon dilation ${ }^{30,31}$. However, before we are able to make strong recommendations on this matter, it is desirable to perform an RCT with a large sample size.

\section{Future perspectives and recommendations}

The large Snapshot cohort from patients who underwent rectal surgery in 2011 as is a good example as to what collaboration on a national scale can do ${ }^{32}$. From this and other national databases, we will be able to gain more insight in several research questions, because we can access large pools or retrospective data. The ultimate scientific method however remains the randomized controlled trial. In the case of colorectal anastomotic leakage, large patient numbers are needed to gain sufficient strength because of the relatively low incidence of the complication. Together with other members of the Taskforce Colorectal Anastomotic Leakage, we are finally able to initiate large RCTs in multiple centres and to answer burning questions in the field of colorectal surgery.

\section{PART IV: Novel insights in the (patho)physiology of anastomotic healing and leakage}

In the final part of this thesis, we have aimed to increase the understanding of the processes and structures of the intestine involved in colorectal anastomotic healing and leakage. We have focused on possible novel preventive techniques that aim directly to these structures and mechanisms of interest. In Chapter 7 we investigated the use of butyrate to support the healing processes of the intestinal wall after colonic resection in a rat model. This study is the first that aims to improve the method of butyrate supplementation in animal models. Butyrate is known to restore epithelial integrity, decrease apoptosis, and mediates the colonic inflammatory response ${ }^{33,34}$. In this chapter, we investigated whether enemas and/or intraluminal patches are suitable to deliver butyrate directly to the cells of interest: the colonocytes. Unfortunately, in this study, a single injection of butyrate in the colonic lumen right before construction of the 
anastomosis was insufficient to ameliorate healing in the colon, whilst an intraluminal patch caused severe stenosis. Despite the disappointing results from this study with regards to the methods to deliver the drug of interest to the site of the anastomosis, we believe that treatment with butyrate with the right vector can enhance the patency of the colonic anastomosis, making it less susceptible to anastomotic leakage. Several new approaches are currently being investigated, such as nano-based drug delivery systems that allow to encapsulate and slowly release drugs that the site of interest ${ }^{35,36}$.

Another important factor that we believe plays a major role in the protection against CAL is the mucus layer. Despite the fact that it is the first line of defence in the gastrointestinal tract, it has remained largely overlooked in colorectal surgery and anastomotic leakage. In Chapter 8 we investigated the protective role of the mucus layer in heterozygous and muc2 knockout mice, and studied whether the influence of prostaglandin E2 (PGE2), a product of the two isoforms of cyclo-oxygenase (COX) 1 and 2 , could improve anastomotic healing. As expected, the leakage rates for Muc2 knockout were much higher than those of heterozygous animals, but I was unable to establish a relationship between the supplementation of PGE2 and healing in this model. This can be explained by the fact that in these knockout mice, there was no mucus layer present at all, and it could therefore not be enhanced. It remains interesting to investigate whether enhancement of mucus layer thickness in humans by means of PGE2 supplementation is possible and leads to increased protection of the bowel wall against pathogens and surgical stress. Furthermore, this mucus layer is a habitat of a wide range of bacterial species, which are known to have important functions and interactions with the bowel itself. Indeed, butyrate (investigated in Chapter 7) is produced by some of these bacteria, as they break down dietary fibres into short-chain fatty acids (SCFA's). As mentioned before, these SCFA's comprise an important nutritional source for the enterocytes.

Over the recent years, important new insights have been created regarding the influence of the microbiome of the gut on bowel wall physiology, and-more specifically - on the incidence of colorectal anastomotic leakage. It has been shown for example that gut bacteria influence the vascularisation of the intestinal mucosa and the processes of wound healing ${ }^{37}$. While the some bacteria can obviously hamper healing and induce inflammation, compelling evidence suggests that the presence of other species of bacteria can lead to improved healing ${ }^{38}$. Germ-free versus conventional studies have shown that the presence of bacteria increases the tensile strength of the wound ${ }^{39}$. The group of Alverdy et al. has done important work on the influence of certain pathogenic species such as collagenase-producing $\mathrm{E}$. faecalis on the healing anastomosis ${ }^{40-42}$. 
During the past few years, compelling evidence regarding the negative influence of NSAIDs on the healing of the colorectal anastomosis has led to the ban of these drugs during the perioperative period. However, the precise mechanisms behind this have been not completely unravelled. Several authors have suggested interplay between NSAIDs and the composition of the microbiome to be the cause of these detrimental effects of this drug type. In Chapter 9, we have looked in depth in the relationship between non-steroidal anti-inflammatory drugs and the luminal microbiome composition in a rat model for anastomotic leakage, and found that not NSAIDs, but the surgical damage itself was the most important contributing factor for the postoperative shift in microbiota.

\section{Future perspectives and recommendations}

The use of mechanical bowel preparation and oral and/or systemic antibiotics have a major impact on the composition of the microbiome. Whilst mechanical bowel preparation leads to relatively short-term alteration of the microbiome (due to loss of the mucosal mucus, which is an important habitat for bacteria ${ }^{43}$ ), antibiotics affect the composition in a more severe and long lasting manner ${ }^{44-46}$. The microbial imbalance that is caused by any form of bowel preparation may negatively affect the processes involved in intestinal healing ${ }^{47}$. We believe that future therapies should be directed at specific pathological bacteria and that we should aim for preservation of the 'normal' microbiome of the gut.

We believe that fundamental understanding of the processes involved in normal healing of the intestine is crucial to the development of new preventive techniques for CAL. We are currently working with an innovative method to clarify the processes of intestinal healing and leakage: mass spectrometry imaging (MSI). MSI allows us to assess the spatial distribution of a wide range of molecules, possibly detecting prognostic markers and identifying pathways as a target for effective therapies. We have recently set up a longitudinal, discovery based experiment that combines high-resolution massspectrometry imaging data with results from immunohistochemistry staining on tissue of the healing and leaking anastomoses of the rat colon. In this study, we aim to unravel the mechanistic processes behind normal anastomotic healing and those behind colorectal anastomotic leakage. We have constructed a lipid profile for both conditions, which may serve as the basis of additional research into the pathways of healing and leakage. Further analyses on human intestinal tissue will show us whether these processes are also applicable to the human setting, and may eventually lead to the development of methods that may finally ban this dreaded complication. 


\section{References}

1. McDermott FD, Heeney A, Kelly ME, et al. Systematic review of preoperative, intraoperative and postoperative risk factors for colorectal anastomotic leaks. Br J Surg 2015;102(5):462-79.

2. Khan AA, Wheeler JM, Cunningham $C$, et al. The management and outcome of anastomotic leaks in colorectal surgery. Colorectal Dis 2008;10(6):587-92.

3. Walker KG, Bell SW, Rickard MJ, et al. Anastomotic leakage is predictive of diminished survival after potentially curative resection for colorectal cancer. Ann Surg 2004;240(2):255-9.

4. Mirnezami A, Mirnezami R, Chandrakumaran K, et al. Increased local recurrence and reduced survival from colorectal cancer following anastomotic leak: systematic review and meta-analysis. Ann Surg 2011;253(5):890-9.

5. Krarup PM, Nordholm-Carstensen A, Jorgensen LN, et al. Anastomotic leak increases distant recurrence and long-term mortality after curative resection for colonic cancer: a nationwide cohort study. Ann Surg 2014;259(5):930-8.

6. Rahbari NN, Weitz J, Hohenberger W, et al. Definition and grading of anastomotic leakage following anterior resection of the rectum: a proposal by the International Study Group of Rectal Cancer. Surgery 2010;147(3):339-51.

7. Buchs NC, Gervaz P, Secic M, et al. Incidence, consequences, and risk factors for anastomotic dehiscence after colorectal surgery: a prospective monocentric study. Int J Colorectal Dis 2008;23(3):265-70.

8. Hammond J, Lim S, Wan Y et al. The burden of gastrointestinal anastomotic leaks: an evaluation of clinical and economic outcomes. J Gastrointest Surg 2014;18(6):1176-85.

9. Konishi T, Watanabe T, Kishimoto J, et al. Risk factors for anastomotic leakage after surgery for colorectal cancer: results of prospective surveillance. J Am Coll Surg 2006;202(3):439-44.

10. Law WL, Chu KW. Anterior resection for rectal cancer with mesorectal excision: a prospective evaluation of 622 patients. Ann Surg 2004;240(2):260-8.

11. Buscail E, Blondeau V, Adam JP, et al. Surgery for rectal cancer after high-dose radiotherapy for prostate cancer: is sphincter preservation relevant? Colorectal Dis 2015;17(11):973-9.

12. Bertelsen $\mathrm{CA}$, Andreasen $\mathrm{AH}$, Jorgensen $\mathrm{T}$, et al. Anastomotic leakage after anterior resection for rectal cancer: risk factors. Colorectal Dis 2010;12(1):37-43.

13. Kang $\mathrm{CY}$, Halabi WJ, Chaudhry $\mathrm{OO}$, et al. Risk factors for anastomotic leakage after anterior resection for rectal cancer. JAMA Surg 2013;148(1):65-71.

14. Slieker JC, Komen N, Mannaerts GH, et al. Long-term and perioperative corticosteroids in anastomotic leakage: a prospective study of 259 left-sided colorectal anastomoses. Arch Surg 2012;147(5):447-52.

15. Sorensen LT, Jorgensen T, Kirkeby LT, et al. Smoking and alcohol abuse are major risk factors for anastomotic leakage in colorectal surgery. Br J Surg 1999;86(7):927-31.

16. Hakkarainen TW, Steele SR, Bastaworous A, et al. Nonsteroidal anti-inflammatory drugs and the risk for anastomotic failure: a report from Washington State's Surgical Care and Outcomes Assessment Program (SCOAP). JAMA Surg 2015;150(3):223-8.

17. van Praagh JB, de Goffau MC, Bakker IS, et al. Mucus microbiome of anastomotic tissue during surgery has predictive value for colorectal anastomotic leakage. Ann Surg 2019;269(5):911-916.

18. Daams F, Wu Z, Lahaye MJ, et al. Prediction and diagnosis of colorectal anastomotic leakage: A systematic review of literature. World J Gastrointest Surg 2014;6(2):14-26.

19. Reisinger KW, Poeze M, Hulsewe KW, et al. Accurate prediction of anastomotic leakage after colorectal surgery using plasma markers for intestinal damage and inflammation. J Am Coll Surg 2014;219(4):744-51.

20. Alves $\mathrm{A}$, Panis $\mathrm{Y}$, Pocard $\mathrm{M}$, et al. Management of anastomotic leakage after nondiverted large bowel resection. J Am Coll Surg 1999;189(6):554-9.

21. Kornmann VN, van Ramshorst B, Smits $A B$, et al. Beware of false-negative $C T$ scan for anastomotic leakage after colonic surgery. Int J Colorectal Dis 2014;29(4):445-51.

22. Marres CCM, van de Ven AWH, Leijssen LGJ, et al. Colorectal anastomotic leak: delay in reintervention after false-negative computed tomography scan is a reason for concern. Tech Coloproctol 2017;21(9):709-14. 
23. Boots AW, van Berkel JJ, Dallinga JW, et al. The versatile use of exhaled volatile organic compounds in human health and disease. J Breath Res 2012;6(2):027108.

24. Jafari MD, Lee $\mathrm{KH}$, Halabi WJ, et al. The use of indocyanine green fluorescence to assess anastomotic perfusion during robotic assisted laparoscopic rectal surgery. Surgical Endosc 2013;27(8):3003-8.

25. Vignali A, Gianotti L, Braga $M$, et al. Altered microperfusion at the rectal stump is predictive for rectal anastomotic leak. Dis Colon Rectum 2000;43(1):76-82.

26. Bingold TM, Franck K, Holzer K, et al. Intestinal Fatty Acid Binding Protein: A Sensitive Marker in Abdominal Surgery and Abdominal Infection. Surgical Infections 2015;16(3):247-53.

27. van den Bos J, Al-Taher M, Schols RM, et al. Near-infrared fluorescence imaging for real-time intraoperative guidance in anastomotic colorectal surgery: a systematic review of literature. J Laparoendosc Adv Surg Tech A. 2018;28(2):157-67.

28. Hirst NA, Tiernan JP, Millner PA, et al. Systematic review of methods to predict and detect anastomotic leakage in colorectal surgery. Colorectal Dis 2014;16(2):95-109.

29. Habib K, Gupta A, White D, et al. Utility of contrast enema to assess anastomotic integrity and the natural history of radiological leaks after low rectal surgery: systematic review and meta-analysis. Int J Colorectal Dis 2015;30(8):1007-14. 5

30. Garcea G, Sutton CD, Lloyd TD, et al. Management of benign rectal strictures: a review of present therapeutic procedures. Dis Colon Rectum 2003;46(11):1451-60.

31. Pickhardt PJ, Edwards K, Bruining DH, et al. Prospective trial evaluating the surgical anastomosis at oneyear colorectal cancer surveillance: CT colonography versus optical colonoscopy and implications for patient care. Dis Colon Rectum 2017;60(11):1162-7.

32. Dutch Snapshot Research G. Benchmarking recent national practice in rectal cancer treatment with landmark randomized controlled trials. Colorectal Dis 2017;19(6):O219-031.

33. Mathewson ND, Jenq R, Mathew AV, et al. Gut microbiome-derived metabolites modulate intestinal epithelial cell damage and mitigate graft-versus-host disease. Nat Immunol 2016;17(5):505-13.

34. Furusawa $Y$, Obata Y, Fukuda S, et al. Commensal microbe-derived butyrate induces the differentiation of colonic regulatory T cells. Nature 2013;504(7480):446-50.

35. Dolati S, Sadreddini S, Rostamzadeh D, et al. Utilization of nanoparticle technology in rheumatoid arthritis treatment. Biomed Pharmacother 2016;80:30-41.

36. Fasehee H, Dinarvand R, Ghavamzadeh A, et al. Delivery of disulfiram into breast cancer cells using folate-receptor-targeted PLGA-PEG nanoparticles: in vitro and in vivo investigations. J Nanobiotechnology 2016;14:32.

37. Reinhardt C, Bergentall M, Greiner TU, et al. Tissue factor and PAR1 promote microbiota-induced intestinal vascular remodelling. Nature 2012;483(7391):627-31.

38. Hooper LV, Wong MH, Thelin A, et al. Molecular analysis of commensal host-microbial relationships in the intestine. Science 2001;291(5505):881-4.

39. Okada M. The influence of intestinal flora on wound healing in mice. Surg Today 1994;24(4):347-55.

40. Shogan BD, Belogortseva N, Luong PM, et al. Collagen degradation and MMP9 activation by Enterococcus faecalis contribute to intestinal anastomotic leak. Science Transl Med 2015;7(286): 286ra68.

41. Shogan BD, Smith DP, Christley $S$, et al. Intestinal anastomotic injury alters spatially defined microbiome composition and function. Microbiome 2014;2:35.

42. Guyton K, Alverdy JC. The gut microbiota and gastrointestinal surgery. Nat Rev Gastroenterol Hepatol 2017;14(1):43-54.

43. Strocchi A, Bond JH, Ellis C, et al. Colonic concentrations of hydrogen and methane following colonoscopic preparation with an oral lavage solution. Gastrointest Endosc 1990;36(6):580-2.

44. Ianiro G, Tilg H, Gasbarrini A. Antibiotics as deep modulators of gut microbiota: between good and evil. Gut 2016;65(11):1906-15.

45. Dethlefsen L, Relman DA. Incomplete recovery and individualized responses of the human distal gut microbiota to repeated antibiotic perturbation. Proc Natl Acad Sci U S A 2011;108 Suppl 1:4554-61.

46. Perez-Cobas AE, Artacho A, Knecht $\mathrm{H}$, et al. Differential effects of antibiotic therapy on the structure and function of human gut microbiota. PloS One 2013;8(11):e80201.

47. Bachmann R, Leonard D, Delzenne N, et al. Novel insight into the role of microbiota in colorectal surgery. Gut 2017;66(4):738-49. 


\section{Part V}

Addendum 

English summary 



\section{English summary}

In Europe, colorectal cancer (CRC) is the second most common cause of cancer related deaths in both men and women. It is the second most common form of cancer in women preceded only by breast cancer, and the third most common in men, after lung and prostate cancer. The incidence rates are strongly influenced by behavioural risk factors such as smoking, poor diet (low consumption of fruits and vegetables, and high consumption of red meats), obesity, physical inactivity, and alcohol consumption. Over the past years, a rapid increase of the overall incidence of colorectal cancer has been observed, which can be contributed to the adaptation of a more western lifestyle and diet in medium to high human development index (HDI) countries, and the implementation of national screening programmes in the highest indexed HDI countries. It is thought that these incidence rates will continue to rise even further during the next few decades; some even estimate a 60\% increase by 2030.

An important corner stone for treatment of CRC remains surgery, which is often combined with (neo)adjuvant chemo(radio)therapy, depending on tumour location and stadium. Important improvements have been made over the past decades with regards to the perioperative care of the colorectal patient, including the implementation of 'fasttrack' protocols and, for example, minimal invasive surgery. Despite these improvements, complications are not uncommon after this type of surgery, and colorectal anastomotic leakage in particular is still the most feared one. Anastomotic leakage occurs when the anastomosis does not heal properly, leading to the leakage of luminal content (faeces and bacteria), into the normally sterile abdominal cavity, which can result in abscess formation, peritonitis and, in severe cases, sepsis.

In around $7-12 \%$ of cases of colorectal surgery, leakage of the anastomosis occurs, which is associated with a prolonged hospital admission, an increased risk of reoperation and ICU admission, and mortality. Several large studies have also shown an association between anastomotic leakage and an impaired oncological outcome, for example a decreased disease-specific survival and an increased risk of recurrence.

Despite the intensive research that has been done on this topic during the past decades by research groups worldwide, we have been unable to bring down the numbers of leakages. This can largely be contributed to the lack of understanding of the processes involved in the normal healing of the gut and the pathways involved in leakage.

\section{Formulating a definition for colorectal anastomotic leakage}

What is considered to be the definition of colorectal anastomotic leakage varies considerably from physician to physician. The existing definitions are rather vague and, 
therefore, not used in clinical practice. This makes comparison of large randomized studies and their outcomes difficult, and hampers the formulation of guidelines. The first part of this thesis focuses in more detail on this problem. We used a survey (Chapter 2) and a large literature study (Chapter 3) to specify what exactly clinicians think anastomotic leakage is. The survey was conducted both in the Netherlands and in China, and showed that there are large regional differences as to what clinicians consider leakage. This can explain the large variation in reported incidence rates between studies conducted in the East and the West. With the literature study, we looked closer into the definitions used and what surgery-related parameters are described in the studies. It appeared that most authors prefer to use their own wording and definitions rather than definitions that were formulated by others. Also, the information provided on the cases that were included in the study with regards to the surgery and the postoperative course varied strongly between studies. Together with the Dutch Taskforce for Anastomotic Leakage, we drafted a set of 11 points that are advised to be reported in future papers.

The results from these two studies have formed the basis of a consensus study which is currently being conducted by our research group. In this Delphi study (not included in this thesis), we asked a number of highly specialised surgeons around the world to give their input regarding this matter, and through several rounds of questions, we aim to formulate a new definition of CAL. As this new definition will be approved by important authors worldwide, it is very likely to be accepted and used by the rest of the scientific community.

\section{Developing a risk assessment tool for leakage}

In the second part of the thesis, the study protocol of the REVEAL study (Chapter 4) is discussed. The REVEAL study is an on-going prospective observational study that aims to develop an algorithm to assess the risk of developing anastomotic leakage. Before the start of this study, it was not possible for clinicians to assess the risk of leakage adequately, despite our knowledge on the risk factors that were described above. Based on a large number of different parameters such as plasma levels of several inflammatory markers, pre-operative CT scans, breath samples and the composition of the microbiome in stool samples, we aim at developing a risk score that can predict the risk of leakage before patients actually undergo surgery. This would make it easier for the clinician to discuss important aspects of the surgery with the patient, for example whether or not to construct a bowel anastomosis in case of a very high pre-operative risk score. In cases like these, the surgeon and patient could decide to not make an anastomosis, but rather to construct a permanent stoma. Based on the assessed risk, recommendations regarding postoperative monitoring of the patient could also be 
given, such as routine blood tests or CT scans. Another important goal of the REVEAL study is to decrease the time between development of the complication and diagnosis. Studies have shown that early diagnosis and subsequent treatment with antibiotics, drainage or surgery decreases the consequences of a leak significantly.

Chapter 5 presents the results of a subset of patients included in the REVEAL study, in which we used an imaging technique called near infrared fluorescence (NIRF) imaging to assess the perfusion of the intestine. These patients were administered a substance intravenously, that can be visualised in the tissues with the use of a certain light. The better the vascularisation of the intestines, the more blood is delivered to the tissues, which leads to a more intense fluorescent signal. In this so-called pilot study, we found that the intensity of the imaging signal was lower in patients who eventually developed a leak. The study shows that NIRF imaging is a safe and effective method to assess the perfusion of the intestine at the site of the future anastomosis.

\section{Different imaging modalities to assess the quality of the anastomosis}

During the past decade or so, important improvements have been made regarding the in-hospital care of the patient. Enhanced recovery protocols have been drafted to shorten recovery and hospital admission time, and to reduce postoperative complications such as ileus or pneumonia. Whereas certain aspects have been captured in these protocols, other important decisions have to be made for every individual patient, such as whether or not to construct a temporary ostomy. The presence of a temporary ostomy also leads to new discussion points, for example what is the best interval between the index surgery and temporary stoma reversal. In Chapter 6, we used a large national cohort of patients to investigate which of two imaging modalities (colonoscopy or CT scan with contrast) was most suitable to assess the integrity of the anastomosis before patients underwent temporary stoma reversal. In this study, no statistically significant differences were observed between the two tests, but they both have pros and cons. The CT scan with contrast has the risk of being 'false positive', in which it may look as if there is a leak, when in reality there is none. Some advantages for the colonoscopy can be described on the other hand, as it can simultaneously detect new polyps or stenosis of the anastomosis, which could then immediately be treated. However, new randomized studies with larger patient numbers are needed before we can make recommendations for either technique.

\section{Understanding the processes involved in leakage}

In the final part of the thesis, we aimed at increasing the understanding of the processes that are involved in normal intestinal healing and leakage. Three different studies were 
discussed in this section. In Chapter 7 we investigated whether supplementation of a specific substance called butyrate would reduce the risk of colorectal anastomotic leakage in rats. Butyrate is a so-called short-chain fatty acid (SCFA), and forms the main source of energy for the cells of the large intestine. The bacteria that reside in the intestine produce butyrate by the breakdown of dietary fibres. Studies have shown that butyrate has positive effects on cell renewal and that it decreases inflammation in the intestine. In Chapter 7, we looked at three different application routes to deliver butyrate to the intestinal cells: 1 ) by single injection right before construction of the anastomosis, 2) by continuous effusion from a patch that was placed in the lumen, or 3) by intermittent doses of butyrate by means of an enema. The first and second techniques seemed either insufficient or dangerous (the patches caused obstruction of the intestine), but some positive results were observed in the animals that received enemas on several consecutive days. However, this cannot be translated into clinical practice directly, as clinicians are usually weary of giving enemas in the early postoperative phase in case of low rectal anastomoses. During the days after the surgery the anastomosis is still vulnerable, and the risk of rupture of the anastomosis in high due to the increased intraluminal pressure of the enema.

Another study that was discussed in the final part of the thesis was on the mucous layer of the intestine. This study was conducted in collaboration with a research group in Gothenburg, Sweden. The entire intestine is lined by a layer of mucous, which forms the first line of defence against passing stool and harmful bacteria. It is produced by a certain cell type of the intestinal wall and provides a natural habitat for certain types of 'beneficial' intestinal bacteria. In the study presented in Chapter 8, a specific strain of mice was used that completely lack this mucous layer, as well as normal 'wild-type' mice. The results from this study showed that this mucous layer is indeed necessary for the normal processes of intestinal healing. Newer studies are needed to investigate methods to support the normal function of the mucous layer.

In several chapters of this thesis, the importance of the composition of the microbiome and 'beneficial' bacteria was mentioned. In other studies it has also been shown that there are certain bacterial strains that pose serious risks for the newly constructed anastomosis. Some bacteria develop harmful characteristics when exposed to certain triggers (for example certain drugs such as opioids, or simply the surgery itself), and produce enzymes that break down the intestinal wall. Another issue that has received a lot of attention in the past decades are the group of drugs of the NSAIDs (non-steroidal anti-inflammatory drugs). These are very commonly used analgesics that are believed to have a negative effect on intestinal healing, by mechanisms that are not yet completely understood. Some have suggested a relation between NSAIDs and the composition of 
the microbiome to be the cause of these detrimental effects. In the final chapter of this thesis (Chapter 9) we have looked in depth into this, and found that not the use of these drugs, but the surgical damage itself was the most important influencing factor for the difference in microbiome composition after surgery. 

Nederlandse samenvatting 



\section{Nederlandse samenvatting}

Darmkanker is de tweede meest voorkomende oorzaak van kanker-gerelateerde sterfte voor zowel mannen als vrouwen. Het is de tweede meest voorkomende vorm van kanker bij vrouwen na borstkanker, en wordt bij mannen alleen voorafgegaan door long- en prostaatkanker. De incidentie wordt voor een belangrijk deel beïnvloed door de levensstijl van patiënten, waarbij men moet denken aan factoren als roken, slechte eetgewoonten (lage consumptie van groenten en fruit, hoge consumptie van rood vlees), obesitas, weinig beweging en het gebruik van alcohol. De afgelopen paar jaar werd er een sterke toename van het aantal gevallen van darmkanker gezien, welk kan worden toegeschreven aan het ontwikkelen van een meer Westerse levensstijl en dieet in landen met een middel tot hoge ontwikkelingsindex (Engels: human development index (HDI)), en door de start van nationale screeningprogramma's in de landen met de hoogste ontwikkelingsindex. Men verwacht dat deze incidentie nog alleen maar verder zal stijgen de komende decennia; experts spreken zelfs over een toename van $40 \%$ in 2030.

De belangrijkste hoeksteen voor de behandeling van colorectaal carcinoom blijft nog altijd chirurgie, welk vaak wordt gecombineerd met (neo)adjuvante chemo(radio)therapie, afhankelijk van de tumor locatie en het stadium waarin de ziekte verkeert. De afgelopen decennia werden er belangrijke verbeteringen doorgevoerd in de perioperatieve zorg van de colorectale patiënt, zoals ook de implementatie van 'snelherstel' protocollen en bijvoorbeeld de introductie van minimaal invasieve chirurgie. Ondanks deze ontwikkelingen zijn complicaties na dit type chirurgie niet ongewoon, en blijft colorectale naadlekkage een erg gevreesde. Colorectale naadlekkage treedt op wanneer de anastomose (naad) niet goed geneest, en leidt tot de lekkage van darminhoud (ontlasting en bacteriën), naar de normaal steriele buikholte. Dit leidt tot de vorming van abcessen, buikvliesontsteking (peritonitis) en in ernstige gevallen, bloedvergiftiging (sepsis).

In ongeveer 7-12\% van de operaties treedt er naadlekkage op, welk geassocieerd is met een verlengde opnameduur, een verhoogd risico op re-operatie, opname op de Intensive Care, en op overlijden. Tevens tonen verschillende grote studies aan dat er ook een relatie bestaat tussen het optreden van naadlekkage en een verhoogd risico op het ontwikkelen van een recidief.

Ondanks de grote aantallen studies die er wereldwijd naar deze complicatie zijn verricht door verschillende onderzoeksgroepen wereldwijd, is het nog niet mogelijk gebleken om het risico op naadlekkage te verminderen. We denken dat dit grotendeels verklaard kan worden omdat er nog weinig inzicht bestaat in de processen die betrokken zijn bij de normale darmgenezing en de pathways betrokken bij naadlekkage. 


\section{Het formuleren van een definitie van colorectale naadlekkage}

Wat precies wordt verstaan onder naadlekkage verschilt sterk van arts tot arts. De bestaande definities zijn erg abstract en worden derhalve weinig toegepast in de dagelijkse praktijk. Dit maakt het vergelijken van uitkomsten van grote gerandomiseerde studies erg moeilijk, en het formuleren van richtlijnen vrijwel onmogelijk. Het eerste deel van dit proefschrift focust daarom op dit probleem. Er werd gebruik gemaakt van een vragenlijst (Hoofdstuk 2) en een uitgebreide literatuurstudie (Hoofdstuk 3) om uit te zoeken wat door artsen precies wordt verstaan onder naadlekkage. The vragenlijst werd zowel in Nederland als in China afgenomen, en toonde grote regionale verschillen tussen de gehanteerde definities van naadlekkage. Dit kan de grote variatie in de gerapporteerde incidentie van naadlekkage verklaren tussen studies die in het Westen en het Oosten werden uitgevoerd.

Met behulp van de literatuurstudie konden we in meer detail kijken naar de definities die gebruikt worden en welke chirurgie-gerelateerde gegevens werden gepubliceerd in de studies. Het bleek dat de meeste auteurs het liefst gebruik maakten van een eigen geformuleerde definitie, en niet van een reeds bestaande definitie. Daarnaast waren er grote verschillen aan te wijzen in de informatie die de auteurs publiceerden over het type chirurgie en het postoperatieve beloop. Samen met de Nederlandse Taskforce Naadlekkage stelden we 11 punten als advies voor toekomstige publicaties.

De resultaten van deze twee studies vormden de basis van een consensus studie die op dit moment wordt uitgevoerd door onze onderzoeksgroep. In deze Delphi studie (die niet in deze thesis werd opgenomen), vroegen we een aantal zeer gespecialiseerde chirurgen wereldwijd om hun mening te geven over deze kwestie. In een aantal rondes waarin de chirurgen hun feedback kunnen geven, zullen we een nieuwe definitie van naadlekkage formuleren. Omdat deze nieuwe definitie wordt goedgekeurd door belangrijke auteurs op het gebied van naadlekkage, is het waarschijnlijk dat deze beter wordt geaccepteerd door anderen die zich bezighouden met colorectale naadlekkage.

\section{Het ontwikkelen van een risicoanalyse voor naadlekkage}

In het tweede deel van dit proefschrift wordt het studie protocol van de REVEAL studie (Hoofdstuk 4) beschreven. Deze REVEAL studie is een nog lopende prospectieve observationele studie gericht op het ontwikkelen van een risicoanalyse voor naadlekkage. Voor de start van deze studie was het voor artsen vrijwel onmogelijk om een goede inschatting te maken van dit risico, ondanks onze brede kennis over risicofactoren zoals hierboven beschreven. Op basis van een groot aantal verschillende parameters zoals bijvoorbeeld plasma concentraties van ontstekingsmarkers, preoperatieve CT scans, uitademingslucht en de samenstelling van de darmbacteriën in 
ontlastingssamples, richten we ons middels deze studie op het ontwikkelen van een risico-score die het risico op naadlekkage al vóór de operatie kan inschatten. Een adequate inschatting van dit risico zou het voor de behandelend arts makkelijker maken om belangrijke aspecten van de operatie met de patiënt te bespreken, bijvoorbeeld de keuze om wel of geen anastomose aan te leggen in het geval van een zeer hoog risico. In deze gevallen zouden de chirurg en de patiënt samen kunnen besluiten om geen darm anastomose, maar liever een permanent stoma aan te leggen. Gebaseerd op het vooraf bepaalde risico zouden er ook aanbevelingen kunnen worden gedaan over het postoperatieve traject, bijvoorbeeld over het routinematig afnemen van bloedsamples of vervaardigen van CT scans.

Een belangrijk nevendoel van de REVEAL studie is het verminderen van de tijd tussen het ontwikkelen van de complicatie en de daadwerkelijke diagnose ervan. Studies hebben namelijk aangetoond dat vroege diagnose en behandeling met bijvoorbeeld drainage, antibiotica of een nieuwe operatie, het risico op ernstig nadeel van de complicatie fors verminderen.

In Hoofdstuk 5 presenteerden we de resultaten van een kleinere studie binnen de REVEAL studie, bij wie er gebruik werd gemaakt van een beeldvormende techniek genaamd nabij-infrarood fluorescentie (NIRF) om de doorbloeding van de darm te kunnen visualiseren. Er werd tijdens de operatie bij deze patiënten een stofje via de bloedbaan toegediend die in weefsels oplicht wanneer er met licht van een bepaalde golflengte op wordt geschenen. Een betere bloedvoorziening van de darmen betekent een grotere intensiteit van het fluorescente signaal. In deze zogenaamde pilotstudie, vonden we dat de intensiteit van het geobserveerde signaal lager was bij patiënten die uiteindelijk naadlekkage zouden ontwikkelen. De studie toonde aan dat NIRF een veilige en effectieve methode is om de perfusie van de darm ter plaatse van de toekomstige anastomose in te schatten.

\section{Verschillende beeldvormende technieken om de kwaliteit van de anastomose te testen}

Tijdens het laatste decennium zijn er belangrijke verbeteringen doorgevoerd in de zorg die wordt geleverd in de dagen rondom de chirurgie. Zogenaamde versneld-herstel protocollen (Engels: Enhanced recovery protocols) werden opgesteld om het herstel en de opnameduur te verkorten, en om postoperatieve complicaties zoals ileus of longontsteking te verminderen. Bepaalde aspecten van de zorg konden reeds in deze protocollen worden gevangen, terwijl andere belangrijke beslissingen per individuele patiënt moeten worden genomen, zoals het wel of niet aanleggen van een tijdelijk dunne darm of dikke darm stoma. De aanwezigheid van een dergelijk ontlastend stoma 
brengt ook weer discussiepunten met zich mee, zoals wat het optimale tijdsinterval is tussen de initiële chirurgie en het opheffen van het tijdelijk stoma. In Hoofdstuk 6 maakten we gebruik van de gegevens die werden verzameld in een groot nationaal cohort van patiënten om te onderzoeken welke van twee diagnostische modaliteiten (colonoscopie of CT scan met contrast) het beste kan worden ingezet om de integriteit van de darmnaad te controleren, voordat het stoma kan worden opgeheven. In deze studie werden geen statistisch significante verschillen gevonden tussen de twee testen, maar er zijn voor beide voor- en nadelen te beschrijven. Bij gebruik van een CT scan met contrast bestaat er het risico dat de test vals-positief is, wat wil zeggen dat het lijkt alsof er een lekkage is, maar dat dit in werkelijkheid niet zo is. Een voordeel van de colonoscopie is dat er tegelijkertijd ook nieuwe poliepen of een stenose van de anastomose kan worden gezien, welk dan direct kan worden behandeld. Echter, op basis van de resultaten van onze studie kunnen hier geen conclusies over worden getrokken, en er zijn grotere gerandomiseerde studies nodig met meer patiënten voordat er aanbevelingen kunnen worden gedaan voor een van de twee modaliteiten.

\section{Meer inzicht in de processen die een rol spelen bij naadlekkage}

In het laatste deel van dit proefschrift hebben we ons gericht op het vergroten van het inzicht in de processen die betrokken zijn bij normale darmgenezing en bij lekkage. In het vierde en laatste deel worden drie verschillende studies beschreven. In Hoofdstuk 7 hebben we onderzocht of de suppletie van een specifieke stof genaamd butyraat (of boterzuur) het risico op naadlekkage in ratten verminderd. Butyraat is een zogenaamde korte-keten vetzuur (SCFA), en vormt de belangrijkste bron van energie voor de cellen van de dikke darm. De bacteriën die in huizen in de darm produceren butyraat door middel van de afbraak van voedingsvezels. Studies hebben aangetoond dat butyraat een positief effect heeft op celvernieuwing en dat het de inflammatie in de darm doet verminderen. In Hoofdstuk 7 hebben we gekeken naar drie verschillende toedieningsmanieren om butyraat aan te bieden aan de intestinale cellen: door een eenmalige injectie direct voordat de naad wordt aangelegd, bij continue afgifte door een patch die in het lumen van de darm werd geplaatst, en door intermitterende doses van butyraat door middel van klysma's. De eerste twee technieken bleken echter onvoldoende effect te hebben of gevaarlijk (de patches zorgden voor een obstructie van de darm), maar er werden wel positieve resultaten gevonden in de groep die klysma's ontvingen. De translatie naar de dagelijkse praktijk is echter niet eenvoudig, omdat artsen vaak terughoudend zijn in het geven van klysma's gedurende vroege postoperatieve fase in het geval van lage darmnaden. Tijdens de eerste dagen na 
chirurgie is de anastomose nog erg kwetsbaar en het risico op ruptuur van de anastomose door de verhoogde intraluminale druk is daardoor hoog.

Een andere studie die werd beschreven in het laatste deel van dit proefschrift is het onderzoek naar de mucuslaag van de darm. Deze studie werd uitgevoerd in samenwerking met een onderzoeksgroep uit Gotenburg, Zweden. De gehele darm is van de binnenzijde bekleed door een mucuslaag die de eerste bescherming vormt tegen passerende ontlasting en schadelijke bacteriën. De mucus wordt geproduceerd door een specifiek celtype in de darmwand en vormt een natuurlijke omgeving voor bepaalde typen goede darmbacteriën. In de studie beschreven in Hoofdstuk 8, werd er een bepaald type muis gebruikt waarbij de mucuslaag in zijn geheel ontbreekt, maar ook normale zogenaamde 'wild-type' muizen. De resultaten van deze studie laten zien dat de mucuslaag inderdaad nodig is voor de normale processen van darmgenezing. Nieuwe studies zijn nodig om methoden te onderzoeken die deze normale functie verder kunnen ondersteunen.

In verschillende hoofdstukken van dit proefschrift werd het belang van de samenstelling van het microbioom en de goede darmbacteriën genoemd. In andere studies werd ook getoond dat er bepaalde bacteriesoorten zijn die een groot risico vormen voor de pas aangelegde anastomose. Sommige bacteriën ontwikkelen schadelijke eigenschappen wanneer ze worden blootgesteld aan bepaalde invloeden (zoals opioiden, of zelfs de chirurgie zelf), en produceren dan enzymen die de darmwand afbreken. Een ander veel onderzocht onderwerp is de invloed van bepaalde medicijnen, de zogenaamde NSAIDs (non-steroïdale anti-inflammatoire drugs, bijvoorbeeld diclofenac of ibuprofen). Dit zijn zeer veelgebruikte pijnstillers waarvan wordt gedacht dat ze een negatief effect hebben op de darmgenezing. Het mechanisme hierachter is echter nog niet geheel opgehelderd. Sommige auteurs suggereerden dat er een verband zou bestaan tussen het gebruik van NSAIDs en de samenstelling van het microbioom die zou zorgen voor deze negatieve effecten. In het laatste hoofdstuk van dit proefschrift (Hoofdstuk 9) werd er in detail gekeken naar deze relatie, en werd er gevonden dat niet zozeer deze medicijnen, als wel de chirurgische schade zelf de meest belangrijke factor was voor de verandering in samenstelling van het microbioom na chirurgie. 

Valorisation 



\section{Valorisation}

The societal and economic impact of scientific research has become increasingly important during the last decade. This chapter therefore focuses on the impact that the knowledge acquired from the different projects described in this thesis may have on the society and economy, and discusses the influence these results have on the current scientific focus in the field of colorectal anastomotic leakage.

\section{Economical and societal impact}

10,000 oncological colorectal resections are performed on a yearly basis in the Netherlands. Of these, 10\% (1000 patients) will be complicated by colorectal anastomotic leakage (CAL). It is predicted that the incidence rates of colorectal carcinoma will increase substantially over the next decades due to the implementation of the national screening programme for colorectal cancer and the ageing population. This would also implicate a strong increase in patients suffering the consequences of CAL. Patients who develop CAL experience significant morbidity, and the mortality rates associated with the occurrence of CAL are also still high: around $15 \%$ of the patients who develop a leak will eventually die of the consequences. These numbers/percentages have remained equally high the last decades.

The occurrence of the complication after colorectal surgery causes a three- to fivefold increase in healthcare costs compared to a similar surgery with a normal postoperative course. The exact additional costs associated with CAL have not been intensively studied in the Netherlands, but American studies have calculated the extra financial burden associated with leakage per 1000 operated patients to lay around 25.7 million euros. These costs are mainly generated due to the prolonged hospital stay (7-10 days), the increased employment of diagnostic tests, reoperations, and/or when the patient is temporarily admitted to the intensive care unit. The costs that are indirectly involved with the complication are generated in rehabilitation, physiotherapy and prolonged absence from work.

The burden of the complication goes beyond its economical impact, as CAL is also associated with a substantial impact on the Health-Related Quality of Life (HRQoL) of our patients. It is believed that quality of life is affected by the same factors that cause the increase in costs associated with CAL (prolonged hospital stay, absence from work), but also by the need of the construction of a stoma. If a reoperation is needed when CAL occurs, the anastomosis is usually taken down and a permanent colostomy is 
constructed. Studies have shown that these stomas (either temporary or permanent) severely affect patients' body image and quality of life and lead to depression and anxiety. Lastly, the occurrence of CAL has been associated with an impaired oncological outcome, leading to an increase in local recurrence and a decrease in disease-specific survival.

\section{Reducing the incidence of CAL}

We believe that it is possible to achieve a significant reduction in the incidence of leakage rates and the associated morbidity and mortality by a combination of several techniques. We feel that with the REVEAL study, that currently is still on-going in the MUMC+ in Maastricht, Zuyderland Medical Centre in Sittard-Geleen/Heerlen and in VieCuri Medical Centre in Veldhoven, an important step in the right direction can be made. We believe that a combination of patient-derived factors such as a compromised immune response, sarcopenia, genetic predisposition, an aberrant intestinal microbiome composition, and surgery-related factors such as surgical stress, ischemia and a derailed systemic response, are responsible for the occurrence of CAL. Based on data from our own previous studies, in which we found that certain plasma markers and genetic factors are predictive of the risk of CAL, the REVEAL study is set up to collect a large set of patient data and patient samples (plasma, exhaled air, faeces, buccal swabs, tissue). With these data and with the use of machine-learning models, we will be able to assess the risk of the development of CAL in every individual patient. Until now, it has been extremely difficult to predict which patient will leak following surgery; no specific lab test exists that gives an adequate indication for the risk, and also the findings during surgery (e.g. aspect of the bowel and the quality of the anastomosis) have been shown to be of insufficient predictive value for CAL. With the results of the REVEAL-study, we will be able to make an adequate estimation of the risk of CAL for every individual patient, even before they have been subjected to surgery. A clear risk classification - and the associated guidelines for each risk class - will ameliorate communication between clinicians and patients. Moreover, with these results, one can also identify the patients with low risk of leakage, possibly saving them from an unnecessary deviating stoma and the associated impact on their quality of life. With the results from the REVEAL-study, the decision to construct an anastomosis or to opt for a permanent colostomy in the frail patient will no longer be based on the 'gut feeling' of the surgeon, but supported by evidence from a large multicentre observational study. As we have passed the $80 \%$ inclusion of in total 558 patients, we expect to be able to present the first results shortly. 
Beside the preoperative risk assessment, the REVEAL study has a second important goal: to shorten time to diagnosis of CAL following surgery. This would also lead to a decrease in mortality and health care costs, as research has shown that early diagnosis leads to improved outcome. Lastly, a combination of metabolic and microbial signatures derived from the REVEAL data, more insight is generated in the processes of colorectal anastomotic healing and leakage. This could also lead to the development of new preventive and treatment strategies, such as nutritional interventions or influencing the microbiome by anti- or probiotics etcetera - strategies that are desperately needed, as our current best preventive method of severe CAL is a deviating stoma.

New research has stressed the importance of the surgery itself as a period that can be influenced in order to improve outcome. We participated in the nationwide Leak Check study, which investigated several factors that can be improved during surgery. This study showed that high peri-operative glucose-levels, low preoperative haemoglobin levels, low body temperature are all modifiable risk factors that can be improved and possibly reduce the rates of leakage. Another important tool that can be used during surgery to aid the battle against CAL is the use of fluorescence imaging to assess the perfusion of the intestine at the future anastomotic site during surgery. This is in line with our own work on intestinal fatty acid binding protein (I-FABP), which is a marker for intestinal damage and shows a significant increase in case of intestinal hypoperfusion.

We believe that in order to further reduce the leakage rates, new and innovative techniques are needed to further reduce the incidence of CAL. In the general introduction of this thesis, we have elaborated on why increased insight in the healing processes of the intestine and the pathophysiology behind CAL is relevant for current and future research. Several studies presented in this thesis have aimed at gaining knowledge on certain pathways, and possible fields of interest for such preventive methods have been investigated. In combination with the results from the clinical study (REVEAL), we will be able to select patients that will benefit most from new therapies, hopefully reducing the risk of a leakage to acceptable levels.

\section{Importance of collaboration}

During the past four years, fruitful collaborations have been established with different research groups in the Netherlands and abroad. Our research group has been part of the Taskforce Colorectal Anastomotic leakage, which is a platform for clinicians and researchers in the Netherlands to exchange ideas on this topic. Collaboration on a national level allows for initiation of new projects in multiple centres simultaneously, of 
which the Leak Check is a good example. The consensus survey and definition review (Chapter 2 and 3, respectively) have already showed what combined (international) forces could bring about. The final part of the quest to a generally accepted definition for CAL is currently being conducted across all continents in the form of a Delphi analysis. In this analysis, many renowned researchers are asked for their opinion and are given the opportunity to elaborate on their thoughts together, eventually coming to consensus about a certain topic. We are positive that the new definition to be presented soon will be adopted by researchers and clinicians worldwide. 
Dankwoord 



\section{Dankwoord}

De eerste drie weken van mijn PhD-carriere trof ik 's morgens een bureau aan dat op zijn kop stond, kreeg ik natte billen van mijn doorweekte bureau-stoel of werd ik er aan vastgetaped en door de gang geduwd. Bedankt daarvoor Bas en Dennis, na deze ontgroening was alles wat erna kwam minder erg (behalve dan de pindakaaspotmove van Dennis.....). Bas, naast mijn personal trainer was je ook een beetje mijn metal coach en kon ik altijd even bij je komen klagen waar ik nu weer ja op had gezegd. Onze passie voor whisky (of is het whiskey?;)) wordt overigens door een schrikbarend groot deel van onze collega's gedeeld. Mo: bedankt voor alle hilarische discussies aan de lunchtafel, je bulderende lach zal me toch wel altijd bijblijven. Annemarie: bedankt voor alle hulp in het lab met de verschillende projecten en sorry voor de honderden studenten die je steeds in de weg liepen en plasma wilden pipetteren met de verkeerde pipet!

Anne-Claire, jij bent toch echt mijn mentor geweest gedurende de eerste twee jaar. We hebben ontzettend veel werk verzet samen (en ook wel veel cocktails een nieuwe naam gegeven in Gothenburg). Ik heb heel veel van je geleerd en ben blij dat ik op de rijdende trein heb kunnen springen die jij samen met Joep in gang hebt gezet! Jij hebt het inmiddels al helemaal voor elkaar: gepromoveerd, al hard op weg met de opleiding, een eigen huis en als kers op de taart ook nog een heerlijke baby gekregen! Geniet van alle moois samen met Jules!

Jacqueline, roomie (de enige echte) en mede-triatleet, ook al kon ik je natuurlijk nooit echt bijhouden. We hebben een gedeelde fetisj voor felgekleurde post-its, markers en bijbehorende labels en al het andere dat ons een gevoel geeft dat we ons leven onder controle hebben. We kwamen er al snel achter dat we nog meer gemeenschappelijk hadden: onze gedeelde allergie voor ademende en smakkende mannen....... Oh en dan nog dit: stay owlsome!

David, liefste collega, trotse papa, handy-man! Bedankt dat ik jullie logee mocht zijn voor een aantal weken, sorry dat ik al jullie flessen wijn heb opgedronken en de koelkast heb leeggegeten. Ik kon altijd terecht bij je voor (gevraagd én ongevraagd) advies over onderzoek, statistiek en natuurlijk over de mannen. Nu worden we opnieuw collega's, mooier kan het bijna niet! Binnenkort maar weer een flesje wijn?

Jasper, het feit dat je ergens verstopt zat bij het transplantatieteam heb je ruimschoots goedgemaakt op het tripje naar Piemonte, drie dagen buikpijn gehad van het lachen.. Jammer dat we allebei de bob moesten spelen, dat doen we de volgende keer anders, 
ok?? Ik weet ook nog goed dat je je twee dagen mentaal moest voorbereiden (met een heel mannelijk blikje bier erbij) op het idee dat je bij mij vegetarisch moest komen eten. Bedankt Jasperke, voor de gezelligheid, tot snel in het MUMC+!

Van Rijn (jr.), collega, super mooi dat we jouw laatste helft opleiding en mijn eerste helft samen mogen werken! Ik kijk uit naar zowel de borrels als de diensten in Mestreech!

Sebastiaan: jij behoorde eigenlijk tot 'nieuwe lichting' collega's, maar bent inmiddels zelf al weer er tussenuit geknepen en als ANIOS aan het werk in Rotterdam. Super leuk dat ik de laatste periode van mijn PhD met jou samen kon werken! Je gaf de boel wat kleur, was altijd lekker relativerend en altijd in voor een welverdiende (soms misschien ook wat minder verdiende) koffie-pauze. Ik had ook ontzettende waardering hoe je de enorme hoeveelheid shit handelde die verschillende instanties (niet nader te noemen) en de industrie over je uitstortten. Ik weet zeker dat je snel die opleiding in vliegt! Oh en hebben we al een idee voor het volgende festivalletje?!

Cathelijne, onze kamers zaten naast elkaar en ik kon jou en Sebastiaan vaak door de muur heen horen gillen haha! Ik heb een enorme waardering voor je doorzettingsvermogen, ook al lukken de experimenten op het lab niet altijd zoals je wilt. Gelukkig kun je je goed afreageren op de fiets (mens wat fiets jij hard) en af en toe op een mooi feestje in onze lokale techno-tempel. Bedankt voor de gezelligheid en alle vermakelijke mekkerende geiten-filmpjes!

Clairtje, Remunjs meadje, lekker wief, (is het nu wat geworden met die ene kerel die er een jaar over had gedaan om je mee uit te vragen?). Ik hoop dat ik je nog af en toe tegenkom nu ik weer terug ben in het zonnige zuiden, maar hoop ook voor je dat je helemaal blij wordt van al het piemels kijken bij de uro!

Valerie: we leerden elkaar pas écht kennen in Chicago, en hoe! Wat een heerlijke tijd hebben we daar gehad! En als kers op de taart mochten we ook nog samen naar Beijing voor het e-nose project.. Er zijn een aantal momenten in Chicago en Beijing die ik nooooit zal vergeten, maar die worden beter niet op papier vastgelegd en 250x uitgeprint.. Het etentje met de staf van het Beijing University Cancer Hospital naar het hot-pot restaurant waar we 3(!) verschillende soorten maag én aorta kregen voorgeschoteld was wel het meest hilarisch, zelfs ondanks (of dankzij?) de enorme kater die we de dag ervoor hadden opgelopen toen we 5000 Chinese yuen hadden opgemaakt in die ene bar. Ik sta nog steeds versteld van jouw energie en hoe snel je dingen oppakt en voor elkaar krijgt; ik hoop dat je net zo veel van mij hebt geleerd als ik van jou! 
Daarnaast ben je natuurlijk een van mijn besties geworden en kan ik heel hard lachen om je uitspraken. We gaan snel weer een 'stampvol' glas wijn drinken, en ik beloof dat ik je niet steeds zal uitmaken voor rotte vis. Ik ben supertrots dat je nu de allerbeste ANIOS Neurosjirurzjie van heel Nederland bent en ik weet zeker dat je alles gaat bereiken wat je maar wilt!

Sofie, Margot, Hidde, Suzan, Leonie, Puck, Roy, Caspar, Gusta: ik kijk ieder jaar weer uit naar de vreselijk fijne weekendjes weg met jullie en de spontane etentjes en borrels tussendoor! Fijn dat we ondanks de afstand onderling onze tradities in ere houden! Jullie zijn inmiddels bijna allemaal al in opleiding en ik moet eigenlijk nog beginnen met het échte werk, trots op jullie!! Sofietje, jou ken ik natuurlijk al heeel lang en ben heel blij om te zien dat het allemaal zo goed gaat: succesvol huisarts, huisje, boompje, beestjes (en dan bedoel ik natuurlijk Funs én Roel)! Op nog vele jaren vriendschap en vele gezellige barbecues!

Awintje, als een van mijn oudste vriendinnetjes ken je me als geen ander! Wat een heerlijke tijd hebben we gehad in Maastricht en wat hebben we veel geleerd in Ferrara toen we daar co-schappen liepen ;) Jij bracht me naar mijn allereerste techno-feestje en ik kijk nu al uit naar de volgende; laten we dan proosten op een succesvolle carrière!

Lieve Ivo, ik ben blij dat we elkaar al zooo lang kennen en ondanks de afstand en het tijdgebrek altijd zulke goede vrienden zijn gebleven! Als we weer aan de wijn (en grappa) bij sjiek zitten voelt het alsof het gisteren was dat we elkaar voor het laatst zagen. Wat een heerlijke avonden hebben we gehad in Maastricht! Zonder jou zou mijn studentenen promotieperiode niet hetzelfde zijn geweest. Ik ben heel blij voor je dat je in Julia de liefde hebt gevonden en dat jullie samen beginnen aan weer een nieuw ondernemersavontuur!

Alle andere dierbare collega's van de oude en nieuwe lichting: (onder andere) Frans, Kiran, Irene-Fleur, Martine, Rob, Cathy, Rianne: bedankt voor de mooie tijd op het lab en daarbuiten, tot gauw!

Dear colleagues from the department of M4I, and Tiffany, Shane, P-Max, Anne, Marty, Florian, Berta, Peter, Lieke, Brenda, Bryn, Gert in particular: thank you for the beer and fun (and the occasional karaoke-session)! Oh and also for all the help with those crazy expensive instruments and horribly complicated data-analyses of course :) It was a lot of fun working alongside with you guys! 
Lieve nieuwe/oude collega's van het AMC (in het bijzonder Egle, Michelle, Jelle, Thomas, Irene, Sebastia(an), Simba, Anne-Loes, Charlotte, Annelot, Wing, Maarten, Rosanna, Erik, Victor, Kristian, Karin, Stefanie, Olivier, Arja, Franceline, Gijs, Thony, Hilko, Sanne, Malaika, Renee, René, Caroline, Daphne, Tomek, Wietse en Wytze): ik leerde een aantal van jullie al snel kennen tijdens de legendarische ski-trip, bedankt dat jullie me ondanks mijn te korte rode jurkje en te ordinaire laarzen en pornopruik toch gewoon hebben opgenomen in jullie team (voor wie het niet weet: ik hoorde bij team spice girls, die zijn nou eenmaal ordi...)! Bedankt ook voor alle gezellige borrels in het AMC en daarbuiten en de leerzame diensten! Jullie zijn allemaal toppers! Ik ben met de switch terug naar regio VIII écht niet meer AMC, maar ik kijk met een heel goed gevoel terug op de periode in het Amsterdamse.. Wie weet waar we elkaar weer tegenkomen!

Natuurlijk ook mijn nieuwe collega's van het MUMC+, ik werk pas met jullie samen maar ik voel me inmiddels al helemaal thuis. Wat zijn jullie fijne mensen en wat leer ik veel van jullie! Ik kijk ontzettend uit naar de komende 6 jaar!

Prof Alverdy: thank you very much for letting Valerie and me loose in your lab where we could take a peak at your innovative laboratory techniques and surgical models. We felt at home immediately and the four weeks in Chicago turned out to be both extremely productive and festive weeks! I hope that we will be able to further expand our collaboration.

Ron Heeren: dank voor de bijzondere samenwerking tussen onze toch wel zeer verschillende disciplines! Dank ook voor het enthousiasme dat je had voor alle nieuwe ideeën die we aandroegen, en voor de ruimte die ik kreeg om zelf aan de slag te gaan met de MSI! Ik heb er vertrouwen in dat we ons gezamenlijke project tot een mooi einde gaan brengen!

Kaatje: Veel dank voor alle hulp en de gezelligheid op het lab en daarbuiten. Wat vind ik het mooi dat je naast mijn mede-triatleet ook mijn copromotor bent geworden!

Silverback Steven, bedankt voor de mooie tijd op je lab en fijn dat ik de laatste jaren heb kunnen doorbrengen in die Google-achtige omgeving. Ik ben benieuwd waar je carrière je uiteindelijk nog allemaal gaat brengen en ik kijk uit naar alle Nature-papers! ;)

Nicole: ik had me geen fijnere promotor kunnen wensen! Altijd een luisterend oor voor de perikelen met de verschillende projecten en altijd geïnteresseerd in mijn privéleven ;) Ik kan me de keer nog goed herinneren dat je een potentiele kandidaat even ging 
screenen op Linkedln en bij je contacten bij het bedrijf waar hij werkte.. Verder wist je met je enorme netwerk en overtuigingskracht me steeds ergens tussen te manoeuvreren zodat ik weer in Beijing aan een studie kon werken, of op het EAES werd uitgenodigd om te spreken (twee keer!). Ik kijk met een trots en voldaan gevoel terug op mijn promotietijd en ik ben blij dat je aanwezig was bij mijn eerste échte operatie!

Joep: je hebt een paar hele succesvolle jaren achter de rug en daarbij genoeg geld ingezameld voor een paar decennia aan onderzoek, lekker bezig!! Je loopt over van enthousiasme en nieuwe ideeën en dat werkt aanstekelijk! Ik vind het fantastisch dat je me naar het AMC hebt gelokt en dat ik daar zo'n mooie tijd heb mogen hebben! Bedankt voor de fijne begeleiding en de motivatie gedurende de afgelopen 5 jaar, en ik hoop dat we samen nog veel mooi onderzoek mogen doen!

Mama en papa, van jullie heb ik geleerd door te zetten en dat er altijd meerdere wegen naar Rome leiden. Mama, dank ook voor de vele kaarsjes die je hebt opgebrand in Heppeneert als er weer wat spannends aan zat te komen (middelbare schoolexamen, vliegreis, proefschriftverdediging) en voor alle homeopathische meuk die je me aansmeerde als ik spierpijn ofzo had. Het heeft echt geholpen. Ik hou van jullie!

Lieve Remy, Iris en Vivian (en Frens natuurlijk ook), jullie hebben me veel moeten missen nadat ik ben gaan studeren en toen ik ook nog ging verhuizen naar de grote stad.. Inmiddels weer gezellig terug in het Maastrichtse, dus kan ik weer vaker op bezoek bij jullie en ook bij Lyam! Wat een heerlijk vrolijk menneke is het toch! Jullie hebben me vaak laten weten hoe trots jullie op me zijn en dat gevoel is wederzijds, ik denk dat we het 'schouders eronder en door' toch in onze genen zit!

And last (but definitely not least) Emilio, I cannot describe how grateful I am that you stuck by me during the final months of completing this thesis. Thank you so much for all your support and understanding, and for all the dinners you cooked for me when I was working late.. I love you and I am proud of everything you do! 

List of publications 



\section{List of publications}

Bosmans JW, Jongen AC, Bouvy ND, Derikx JP. Colorectal Anastomotic Healing: Why unravelling the biological process that leads to anastomotic leakage should be the main priority prior to conducting intervention studies - BMC Gastroenterol. 2015 Dec 21;15:180

Jongen AC, Bosmans JW, Kartal S, Lubbers T, Sosef M, Roumen RM, Stoot JH, Derikx JP, Bouvy ND Predictive factors for anastomotic leakage after colorectal surgery: The REVEAL-study. A study protocol for a prospective observational study - JMIR Res Protoc. 2016 Jun 9;5(2):e90

Bosmans JW, Jongen AC, Boonen BT, van Rijn S, Scognamiglio F, Stucchi L, Gijbels MJ, Marisch E, Bouvy ND. Comparison of three different application routes of butyrate to improve colonic anastomotic strength in rats - Int J Colorectal Dis. 2017 Mar;32(3):305313

Bosmans JW, Jongen AC, Birchenough GM, Gijbels MJ, Nyström EE, Derikx JP, Bouvy ND, Hansson GC. Functional mucous layer and healing of proximal colonic anastomoses in an experimental model - Br J Surg. 2017 Apr;104(5):619-630

van Rooijen S*, Jongen AC*, Wu ZQ, Ji JF, Slooter GD, Roumen RM, Bouvy ND - Definition of colorectal anastomotic leakage: A consensus survey among Dutch and Chinese colorectal surgeons - World J Gastroenterol. 2017 Sep 7;23(33):6172-6180

Schuermans VN*, Ziyu Li*, Jongen AC, Wu Z, Shi J, Ji J, Bouvy ND. Pilot study: Detection of gastric cancer from exhaled air analysed with an electronic nose in Chinese patients Surg Innov. 2018 Oct;25(5):429-434

Van den Bos J, Jongen AC, Melenhorst J, Breukink S, Lenaerts K, Schols RM, Bouvy ND, Stassen LPS - Near-infrared fluorescence image-guidance in anastomotic colorectal cancer surgery and its relation to serum markers of anastomotic leakage: a clinical pilot study - Surg Endosc. 2019 Feb (Epub ahead of print)

Jongen AC*, van Rooijen SJ*, Schuermans VN, Wu Z, Roumen RM, Slooter GD, Bouvy ND - Use of colorectal anastomotic leakage definitions in literature: results of a systematic review and recommendations for future reporting - Submitted 
Jongen AC*, Yauw ST*, Klabbers RE, Lomme RM, Bouvy ND, Savelkoul PH, Penders J, van Goor H. - The shift in microbial composition and diversity in a rat model of NSAID induced anastomotic leak can be attributed to surgical stress - Submitted

Mommers E, Hong L, Jongen AC, Bouvy ND - Baseline performance of the ischemic button model for induction of adhesions in male and female laboratory rats - Submitted

Bosmans JW, Jongen AC, Scognamiglio F, Boonen BT, Hoebers N, Gijbels MJ, Jocken JW, Bouvy ND - Caution should be taken with glycerol as plasticizer in biomaterials designed for intra-abdominal use; evidence from in vitro assays as well as an experimental rat model - Submitted

Plat VD, Derikx JP, Jongen AC, Nielsen K, Sonneveld DJ, Tersteeg JJ, Crolla RM, van Dam DA, Cense HA, de Meij TG, Tuynman JB, de Boer NK, Daams F - Diagnostic accuracy of urinary intestinal fatty acid binding protein in detecting colorectal anastomotic leakage

Jongen AC, Meyer YM, Stassen LP, Derikx JP, Bouvy ND, Dutch Snapshot Research Group - Contrast enema vs. colonoscopy prior to temporary stoma reversal in rectal surgery; results of a national snapshot study - In preparation

Book chapter:

Jongen AC, van Woerden V, van Vugt JL, de Hoogt PA, de Wijkerslooth de Weerdesteijn EM, Tegels JJ, Stoot JH - Improving outcome in gastrointestinal and hepatopancreaticobiliary surgical oncology by preoperative risk assessment and optimization of perioperative care. Book chapter - Oncology Critical Care 
Curriculum vitae 



\section{Curriculum vitae}

Audrey Jongen was born on the $20^{\text {th }}$ of July in Sittard, the Netherlands. After graduating from grammar school at the Trevianum in Sittard in 2007, she started her medical training at the University of Maastricht. Her interest in the scientific background of the medical decisions made in clinical practice was aroused during the Bachelor phase of Medicine and she worked several weeks on a clinical database involving patients with cervical cancer at the Maastro Clinic. During the years that followed, she developed a strong preference for the surgical specialties and she decided to do a clinical rotation at the surgery department in Ferrara, Italy. Her final year of Medicine stood also completely in the light of surgery, when she did a combined clinical and scientific rotation under the supervision of Prof. dr. Nicole Bouvy. Directly following this final year, she started a PhD project under the supervision of Prof. dr. Nicole Bouvy, Dr. Joep Derikx, and Dr. Kaatje Lenaerts, which finally resulted in this thesis. After a year of working as ANIOS at the department of general surgery at the Amsterdam University Medical Centres, location AMC, she started her surgical residency at the Maastricht University Medical Centre+ in July 2019 under the supervision of Prof. dr. Laurents Stassen. 
